\author{
UNIVERSIDADE DE SÃO PAULO \\ ESCOLA DE ENGENHARIA DE SÃO CARLOS \\ DEPARTAMENTO DE ENGENHARIA DE PRODUÇÃO
}

SIMONE APARECIDA TIZIOTTO

O Design Universal na Editoração de Material Didático como Agente

Motivador e Estimulador da Autoeficácia para a Aprendizagem 



\section{O Design Universal na Editoração de Material Didático como Agente Motivador e Estimulador da Autoeficácia para a Aprendizagem}

v.1

Dissertação apresentada à Escola de Engenharia de São Carlos da Universidade de São Paulo para obtenção do título de mestre em Engenharia de Produção.

Área de concentração: Economia, Organizações e Gestão do Conhecimento

Orientador: Prof. Dr. José Dutra de Oliveira Neto

São Carlos

2013 
AUTORIZO A REPRODUÇÃO TOTAL OU PARCIAL DESTE TRABALHO, POR QUALQUER MEIO CONVENCIONAL OU ELETRÓNICO, PARA FINS' DE ESTUDO E PESQUISA, DESDE QUE CITADA A FONTE.

T6250

TIzIOTTO, Simone Aparecida

- Design Universal na Editoraçào de Material Didático como Agente Motivador e Estimulador da Autoeficácia para a Aprendizagem / Simone Aparecida TIZIOTTO; orientador José Dutra de OLIVEIRA NETO. Säo Carlos, 2012.

Dissertação (Mestrado) - Programa de Pós-Graduaçăo em Engenharia de Produçăo e Área de Concentraçăo em Economia, Organizaçőes e Geståo Conhecimento -- Escola de Engenharia de Săo Carlos da Universidade de Săo Paulo, 2012 .

1. Design Universal para a Aprendizagem. 2 . Educaçåo a Distancia. 3. Ensino Superior. 4. Material Didático. 5. Inclusåo. 6. Motivaçăo. 7. Autoeficácia para a Aprendizagem. I. Titulo. 


\section{FOLHA DE JULGAMENTO}

\section{Candidata: Licenciada SIMONE APARECIDA TIZIOTTO.}

Título da dissertação: "O design universal na editoração de material didático como agente motivador e estimulador da autoeficácia para a aprendizagem".

Data da defesa: 20/05/2013

\section{Comissão Julgadora:}

Prof. Dr. José Dutra de Oliveira Neto (Orientador)

(Escola de Engenharia de São Carlos/EESC)

Prof. Dr. Edson Walmir Cazarini

(Escola de Engenharia de São Carlos/EESC)

Prof ${ }^{\mathrm{a}}$. Dr ${ }^{\mathrm{a}}$. Vânia Ribas Ulbricht

(Universidade Federal de Santa Catarina/UFSC)

\section{$\underline{\text { Resultado: }}$}

spovado
Aprovado

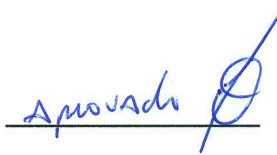

Coordenador do Programa de Pós-Graduação em Engenharia de Produção: Prof. Titular Henrique Rozenfeld

Presidente da Comissão de Pós-Graduação: Prof. Titular Denis Vinicius Coury 
Dedico este trabalho aos meus pais José Vicente Tiziotto e Dalva Rueda Tiziotto (in memorian) pelo carinho, incentivo, dedicação, cuidados, exemplos, força e apoio em todos os momentos e para minha sogra Elisabete Primiano(in memorian) pela amizade, pelos incentivos e pelo exemplo de força. 


\section{Agradecimentos}

A Deus, pelas bênçãos e pela graça de ter me permitido concluir este trabalho.

Ao meuesposo Fabiano PrimianoFechio pelo amor, presença, ajuda, apoio, dedicação e companheirismo em todos os momentos. Amo você!

Ao meu querido irmão Marcos Aurélio Tiziottopela amizade, ajuda e apoio durante a realização deste trabalho e em todos os momentos, às minhas queridas irmãs Soraia Auxiliadora Tiziotto Carolino, Elisa Mara Tiziottoe Ana LuizaTiziotto (Aninha) pela amizade e pelo apoio em todos os momentos de minha vida. Amo vocês!

Às minhas amadas sobrinhas LaisaTiziotto Carolino, LidianeTiziotto Carolino e Isabel PrimianoFechio de Araújo pelos momentos de felicidade que compartilhamos.

Ao Prof. Dr. José Dutra de Oliveira Neto pela orientação, paciência, pela disponibilidade em ajudar e ensinar.

A todos os professores que passaram pela minha escolar e acadêmica pelos exemplos, pela dedicação e ensinamentos.

A todos os técnicos e profissionais que trabalharam na editoração do material didático utilizado para realização deste trabalho.

Aos professores Edson Valmir Cazarini e Vânia Ulbrich pelas importantes considerações que contribuíram para o desenvolvimento deste trabalho.

Á minha família, a todos os amigos e colegas, em especial à Marcia Lygia Ribeiro de Souza Casarine as novas pessoas, professores e profissionais que conheci durante o processo de elaboração deste trabalhopela amizade, apoio e contribuições oferecidas. 
"Toda a nossa ciência, comparada com a realidade é primitiva e infantil - e, no entanto, é a coisa mais preciosa que temos" (Albert Einstein). 


\section{RESUMO}

\section{TIZIOTTO, S.A. O design universal na editoração de material didático como agente motivador e estimulador da Autoeficácia para a Aprendizagem.2013. 182f. Dissertação (Mestrado) - Departamento de Engenharia de Produção, Universidade de São Paulo, São Carlos, 2013.}

No contexto da Educação a Distância Superior no Brasil, o Material Didático tem figurado como um dos principais recursos, no qual, realiza-se a aplicação dos pressupostos do Design Universal para a Aprendizagem, que se trata de um modelo de universalização que propõem o oferecimento de 'andaimes' que visem a eliminar as barreiras desnecessárias, sem eliminar os desafios necessários para beneficiar/proporcionar a aprendizagem do maior número possível de alunos. Ressalta-se que a Motivação e a Autoeficácia para a Aprendizagemtem sido utilizadas em trabalhos brasileiros que as apresentam como importantes dimensões de aprendizagem. Contudo, há escassez de pesquisas que avaliem e mensurem os efetivos impactos destas dimensões no processo de aprendizagem permeado por implementações de propostas didáticas baseadas em princípios do Design Universal para a Aprendizagem. O presente trabalho tem, portanto, o objetivo de avaliar 0 impacto dos princípios do Design Universal para a aprendizagem nas dimensões de Motivação e Autoeficácia do processo de aprendizagem em cursos superiores de Educação a Distância. Portanto, propõem a incorporação de princípios do Design Universal para a aprendizagem por meio da implementação de quatro propostas didáticas (leitura ou audição - voz feminina ou masculina - de texto; videoaula convencional ou com legenda parcialmente ambientada; controle de velocidade da expectação da videoaula; fórum com participação escrita, falada ou gravada com imagem e som) na editoração do Material Didático e testa sua aplicabilidade e efetividade para aumentar os índices de a Motivação e a Autoeficácia para a Aprendizagem. A pesquisa é multimodal e foi arquitetada como um experimento verdadeiro, no modelo de pré-teste/pós-teste, utilizando-se os instrumentos Escala de Motivação Acadêmica e a Escala de Autoeficácia Acadêmica Percebida para aplicação em uma amostra de 238 alunos de cursos EAD de uma IES brasileira. Os resultados qualitativos e quantitativos apresentados evidenciam o potencial do Design Universal para melhoria dos índices de Autoeficácia para a Aprendizagem e da Motivação, em uma proposta que visa mais que permitir a participação, mas possibilitar o sucesso de todos!

Palavras-chave: DesignUniversalpara a Aprendizagem; Educação a distância (EAD);Educação Superior;Material didático; Inclusão;Motivação; Autoeficácia para a Aprendizagem.

\section{ABSTRACT}

TIZIOTTO, S.A.The universal design in publication of courseware as motivator factor and stimulator of self-efficacy for learning.2013. 182f. Dissertation (Master) - Department of Production Engineering, University of São Paulo, São Carlos, 2013.

In the context of Distance Higher Education in Brazil, the courseware has figured as one of the main resources in which executes the application of the assumption of Universal Design for Learning, which it is about a template of universalization that propose the offering of "scaffoldings" that aim to eliminate the unnecessary barriers,, without eliminating the necessary challenges to benefit/provide the learning of the greatest number of students as possible. 
It is noteworthy that the Motivation and Self Efficacy for Learning has been used in Brazilian works that present as important dimensions of learning. However, there is a shortage of searches that evaluate and measure the actual impact of these dimensions in the learning process permeated by implementations of didactic proposals based on the principles of Universal Design for Learning.

The present project has therefore the objective to evaluate the impact of the principles of Universal Design for Learning in the dimensions of motivation and self-efficacy of the learning process in Distance Higher Education courses. Propose the incorporation of principles of the Universal Design for Learning through the implementation of four didactic proposals (reading or listening - female or male voice - text; conventional video lesson or partially acclimated with subtitles; video lesson expectation speed control; board with participation written, spoken or recorded with image and sound) on courseware publication and test its applicability and effectiveness to increase the rates of Motivation and Self-Efficacy for Learning.

The research is multimodal and is architected as a true experiment, in the template of pre-test/pos-test, using the instruments of Academic Motivation Scale and the Scale of Perceived Academic Self-efficacy for using in a sample of 238 students of EAD courses of a Brazilian Institute of Higher Education.

The qualitative and quantitative results presented highlight the potential of Universal Design to improve rates of Self Efficacy for Learning and Motivation, in a proposal that aims more than to allow participation, but enable the success of all!

Keywords: Universal Design for Learning, Distance Learning, Higher Education, Educational material; Inclusion, Motivation, Self-Efficacy for Learning. 


\section{Lista de llustrações}

Figura 1 Referencial de sustentação teórica da pesquisa ................................. 19

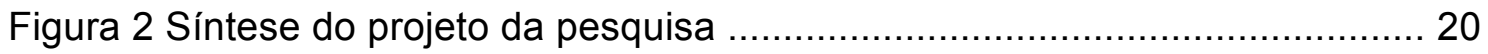

Figura 3 Estrutura do sistema educativo brasileiro ........................................... 24

Figura 4 Tecnologias predominantes nas Gerações da EAD no Brasil ................ 41

Figura 5 Gerações da EAD ............................................................... 42

Figura 6 Redes cerebrais envolvidas no processo de aprendizagem ................. 77

Figura 7 Estrutura da pesquisa experimental ................................................. 93

Figura 8 Visualização do material didático com implementação da primeira proposta didática pautada no princípio I do DU paraaAprendizagem

utilizado narealização do primeiro dia do experimento

Figura 9 Visualização do material didático com implementação da segunda proposta didática pautada no princípio I do DU para a Aprendizagem utilizado narealização do segundo dia do experimento

Figura 10 Visualização do material didático com implementação da terceira proposta didática pautada no princípio I do DU para a Aprendizagem utilizado narealização do terceiro dia do experimento .....

Figura 11 Visualização da implementação da quarta proposta didática pautada no princípio II do DU para a Aprendizagem utilizado na realização do quarto e quinto dias experimento, nas turmas de cursos na área de Ciências Humanas (licenciaturas) e Ciências Tecnológicas, respectivamente 


\section{Lista de Siglas}

ABRAEAD - Anuário Brasileiro Estatístico de Educação Aberta a Distância.

AUTOEFICÁCIA - Autoeficácia para a aprendizagem.

AVAs - Ambientes Virtuais de Aprendizagem.

CF - Constituição Federal da República do Brasil.

$\mathrm{CH}$ - Ciências Humanas.

Corde - Coordenadoria Nacional para integração da Pessoa Portadora de Deficiência.

CT - Ciências Tecnológicas.

DES - Desmotivação.

DU - Design Universal.

EAD - Educação a Distância.

ECA - Estatuto da Criança e do Adolescente.

GC - Grupo de Controle.

GE - Grupo Experimental.

H01- Hipótese de pesquisa 1.

H02- Hipótese de pesquisa 2.

H03- Hipótese de pesquisa 3.

IES - Instituição de Educação Superior.

LDB - Lei de Diretrizes e Bases da Educação Nacional (Lei n. 9.394/96).

Libras - Língua Brasileira de Sinais.

MECE - Motivação Extrínseca por Controle Externo.

MEIDEN - Motivação Extrínseca por Identificação.

MEINTRO - Motivação Extrínseca por Introjeção.

MIR - Motivação Intrínseca para Realização.

MIS - Motivação Intrínseca para Saber.

MIVE - Motivação Intrínseca para Vivenciar Estímulo.

NCU - National Center on Universal Design for Learning.

P\&D - Pesquisa e Desenvolvimento.

PD1_DU1 - Proposta Didática 1, inspirada no Princípio 1 do Design Universal para a Aprendizagem.

PD2_DU1 - Proposta Didática 2, inspirada no Princípio 1 do Design Universal para a Aprendizagem.

PD3_DU1 - Proposta Didática 3, inspirada no Princípio 1 do Design Universal para a Aprendizagem.

PD4_DU2 - Proposta Didática 4, inspirada no Princípio 2 do Design Universal para a Aprendizagem

PDI - Plano de Desenvolvimento Institucional.

PNE - Plano Nacional da Educação.

TI - Tecnologia da educação.

TIC's - Tecnologias da Informação e da Comunicação.

Unesco - Organização das Nações Unidas para a Educação, Ciência e a Cultura.

Unicef - Fundo das Nações Unidas para a Infância. 


\section{Sumário}

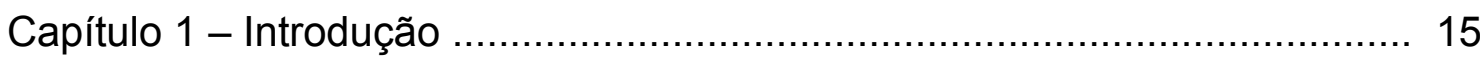

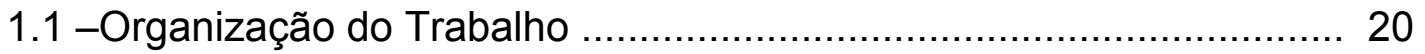

Capítulo 2 - Educação Superior ........................................................ 23

2.1 - Educação Superior no Sistema Educativo Brasileiro ........................ 23

2.2 - Evolução Histórica ...................................................................... 26

2.3 - Tendências e Perspectivas ....................................................... 32

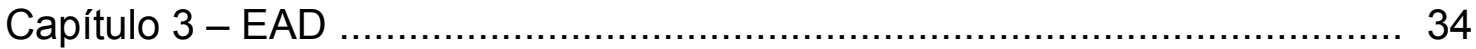

3.1 - Conceituação e Caracterização ..................................................... 35

3.2 - Evolução da EAD no Brasil ........................................................ 41

3.3 - Tendências e Perspectivas ....................................................... 46

Capítulo 4 - Material Didático ………………………........................ 48

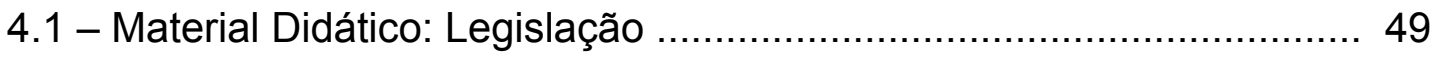

4.2 - Processos de Produção .......................................................... 50

4.3 - Acessibilidade no Material Didático para EAD ............................... 56

4.4 - Dimensões de Sustentabilidade no Material Didático ...................... 57

Capítulo 5 - Design Universal (DU) para a Aprendizagem .......................... 60

5.1 - DU para a Aprendizagem: Introdução, Conceituação e Histórico ..... 60

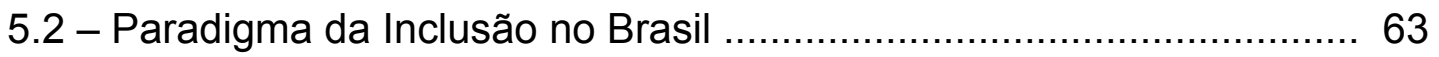

5.3 - Contextualizações da Aplicabilidade de DU na Aprendizagem ......... 66

5.4 - Princípios do DU na Aprendizagem Aplicados ao Material Didático . 68

5.4.1 - Princípio I - Utilizar múltiplos meios de representação do

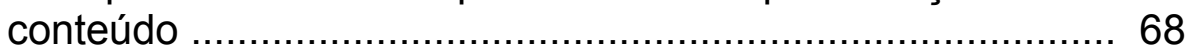

5.4.2 - Princípio II - Utilizar diversos meios de ação e expressão .... 70

5.4.3 - Princípio III - Oferecer diversas formas de engajamento ...... 72

5.4.4 - Princípios do DU: contextualizações gerais e contribuições para o processo de aprendizagem .................................... 74

Capítulo 6 - Motivação e Autoeficácia para a Aprendizagem ....................... 80

6.1 - Motivação para a Aprendizagem …………………...................... 81

6.2 - Autoeficácia para a Aprendizagem ................................................ 84

6.2.1 - Papel da Autoeficácia para a Aprendizagem no Processo

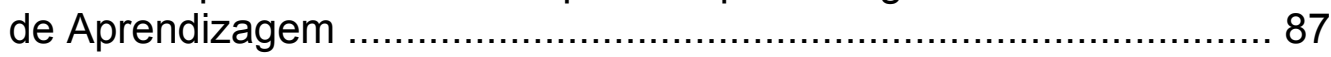

6.3 - Autoeficácia e Motivação: Correlação e Importância para a

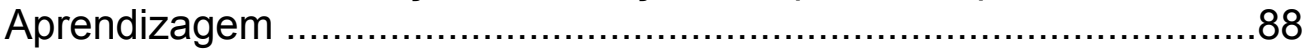

6.4 - Aplicações da Autoeficácia para a Aprendizagem e da Motivação no Material Didático 
Capítulo 7 - Metodologia

7.1 - Contextualização da Implementação das Estratégias do DU para a Aprendizagem no Material Didático 94

7.2 - Procedimentos Experimentais …………………………........... 97

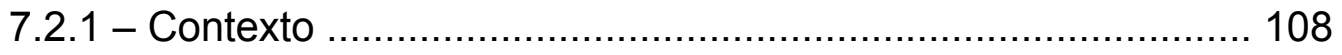

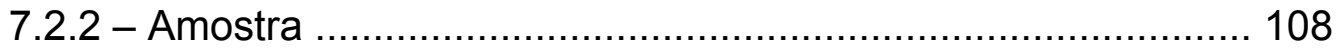

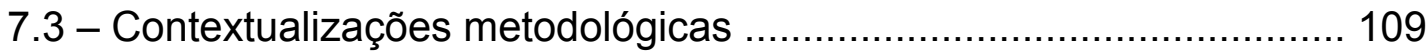

7.3.1 - Modelo Experimental Aplicado ………………….............. 110

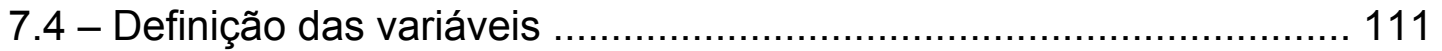

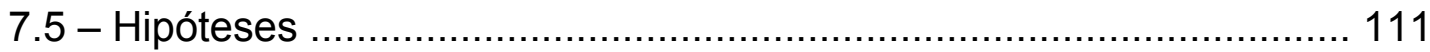

7.6 - Fidelidade ou Precisão, Consistência dos Procedimentos ............... 112

7.7 - Manipulação do Experimento: Modalidade de Entrega das Informações

Capítulo 8 - Resultados e Análise dos Resultados ...................................... 113

8.1 - Proposta Didática 1 inspirada no Princípio I do DU para a Aprendizagem (PD1_DU1) - Escolha entre Leitura ou Audição de um Texto (opção por Voz Feminina ou Masculina) .......................... 113

8.1.1 - Experimento 1: Comparação entre os GE e o GC ................ 113

8.1.2 - Experimento 1: Comparação dos índices identificados no Pré-teste e os alcançados após o contato com o

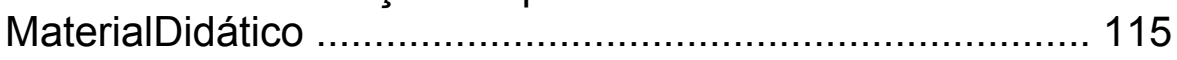

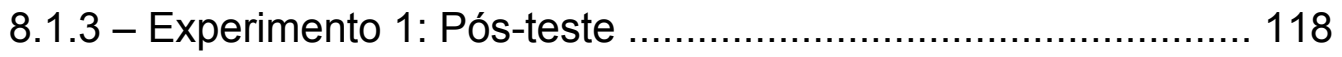

8.1.4 - Experimento 1: Análise Geral dos Resultados ..................... 119

8.2 - Proposta Didática 2 Inspirada no Princípiol do DU para a Aprendizagem (PD2_DU1) - Escolha entre VideoaulaConvencional (Recursos Audiovisuais) ou Videoaula com Legenda Parcialmente Ambientada 121

8.2.1 - Experimento 2: Comparação entre os GE e GC 121

8.2.2 - Experimento 2: Comparação dos Índices Identificados no Pré-Teste e os Alcançados após o Contato com o Material Didático

8.2.3 - Experimento 2: Pós-teste ................................................. 127

8.2.4 - Experimento 2: Análise Geral dos Resultados ..................... 128

8.3 - Proposta Didática 3 Inspirada no Princípio I do DU para a Aprendizagem (PD3_DU1) - Escolha entre Videoaula Convencional ouVideoaula com Controle de Velocidade

8.3.1 - Experimento 3: Comparação entre os GE e o GC 130

8.3.2 - Experimento 3: Comparação dos Índices Identificados no Pré-Teste e os Alcançados após o Contato com o Material Didático 
8.3.3 - Pós-Teste - Experimento 3

8.3.4 - Experimento 3: Análise Geral dos Resultados

8.4 - Proposta Didática 4 inspirada no Princípioll do DU para a

Aprendizagem (PD4_DU4-CH) - Participação no Fórum, com Opçõesde Participação Escrita, Falada ou Gravada com Som e Imagem (Ciências Humanas)

8.4.1 - Experimento 4_CH: Comparação entre o GE e GC

8.4.2 - Experimento 4_CH: Comparação dos Índices Identificados noPré-Teste e os Alcançados Após o Contato com o Material

8.4.3 - Experimento 4_CH: Pós-teste

8.5 - Proposta Didática 4 inspirada no Princípioll do DU para a Aprendizagem (PD4_DU4-CT) - Participação no Fórum, com Opções deParticipação Escrita, Falada ou Gravada com Som e Imagem (CiênciasHumanas) 146

8.5.1 - Experimento 4_CT: Comparação entre o GE e GC 146

8.5.2 - Experimento 4_CT: Comparação dosíndices Identificados no Pré-Teste e os Alcançados Após o Contato com o Material

8.5.3 - Experimento 4_CT: Pós-teste 152

8.5.4 - Experimento 4_CH/CT: Análise Geral dos Resultados 153

Capítulo 9 - Considerações Finais 155

Referências 162

Anexos 181

Anexo I - Escala de Motivação Acadêmica (VALLERAND et. al., 1992; 1993)

Anexo II - itens da Escala de Autoeficácia Acadêmica Percebida (DE SÁ, 2002) 


\section{Capítulo 1 - Introdução}

O processo de construção dos conhecimentos na Educação Superior, independente de sua modalidade, vem sofrendo alterações constantes com o intento de atender às novas formas de ensinar e aprender, bem como de assegurar o sucesso da maioria, ou melhor e se possível, de "todos os discentes" em seus processos de ensino e aprendizagem. As propostas que vêm, portanto, sendo realizadas, em geral, aparecem como respostas às demandas provenientes da sociedade e da própria comunidade acadêmica em busca de soluções para os desafios a ela apresentados.

Nesse contexto, observa-se que, historicamente, a expansão crescente do acesso ao Ensino Médio tem ocasionado uma pressão e, por conseguinte, aumento do acesso à Educação Superior: em 1981, aproximadamente 1.400 mil estudantes tiveram acesso a este nível de ensino. Passados 13 anos, em 1994, ainda não havia 1.700 mil alunos. Entretanto, após esse período o crescimento foi acentuado e, em 1999, esse número chegou a 2.400 mil estudantes em cursos de graduação, $85 \mathrm{mil}$ em cursos de mestrado e doutorado, e uma significativaquantidade de discentes matriculados em cursos de especialização e extensão universitária. Este crescimento era esperado, porque o Brasil, com menos de $8 \%$ dos jovens entre 20 e 24 anos matriculados em IES, está atrasado, se comparado aos países de nível de desenvolvimento semelhante (BRASIL, 2002). Ressalva-se, nesse ínterim, uma profunda preocupação entre os pensadores e literatos que pesquisam este tema, sobre a possibilidade desta expansão não acontecer em detrimento da qualidade do ensino.

Ademais, a sociedade do conhecimento entende que expansão daEducação Superiorbrasileiro ao longo dos tempos, ocorrida em maior ou menor grau, aconteceu não apenas em decorrência direta das demandas do mercado de trabalho por mão-de-obra qualificada, mas também de um fenômeno de mobilidade social, ou seja, a expansão dos sistemas educacionais que têm dinâmica própria.

Nota-se que a relação de causalidade acontece tanto do mercado de trabalho para os sistemas educacionais, quanto pelo oposto, uma vez que são 
os educandos, as instituições educativas e os profissionais, que organizam o referido mercado de acordo com suas finalidades e seus interesses.

Verificou-sena última década, no intento de atender tanto o aumento pela procura da Educação Superior, quanto as novas demandas provenientes da sociedade, um aumento vertiginoso da oferta de cursos superiores na modalidade EAD: o número de cursos de graduação na modalidade EAD cresceu 571\% entre 2003 e 2006; e o número de matrículas, 315\% no mesmo período. Além disso, as IESque ministram cursos de graduação na modalidade EAD aumentaram de sete para 77 em apenas sete anos (ABRAEAD, 2010).

Neste cenário, a EAD, mesmo desassistida em determinados momentos da história, constitui-se de forma crescente, em um importante e eficaz instrumento de democratização do acesso à educação, além de ser uma opção de qualidade, para atender uma parcela considerável da população.

Salienta-se, ainda, que a EAD trata-se de uma modalidade de educação que apresenta características específicas e desafios, tais como os preocupantes índices de evasão, sobre os quais, mesmo reconhecendo outros motivos como fatores determinantes, observam-se nos alunos desistentes uma adaptabilidade pequena ou insuficiente em relação à metodologia que vem sendo praticada para esta modalidade de educação(BRASIL, 2008). Além disso, como mencionado no $\operatorname{ABRAEAD~(2010,~p.~87),~"o~problema~da~falta~de~}$ tempo do aluno, aliada à necessidade de mais atenção para a solução de dúvidas, por exemplo, se sobrepõem a um motivo clássico para a evasão, a falta de dinheiro para a continuidade do curso".

Este contexto, ainda tem sido marcado por outros desafios, como o aumento, especialmente, a partir de 2001, pela procura daEducação Superior por pessoas acima dos 50 anos. A quantidade de novos universitários na referida faixa etária cresceu de 8.709 para 10.721 , variação de $23,1 \%$, enquanto a média no país, levando em conta todas as idades, foi de $16,46 \%$, ou seja, passamos a ter um acesso expandido para além dos discentes habituais (BRASIL, 2008).

Soma-se aos desafios como os índices de evasão e os alunos nãohabituais, conforme dados do IBGE, o fato de cerca de $14,5 \%$ da população Brasileira apresentar algum tipo de deficiência, alémdas inúmeras outras pessoas com dificuldades de aprendizagem. Muitas dessas pessoas, sequer 
pensam em ingressar naEducação Superior devido à falta de incentivo e às inúmeras barreiras encontradas, uma vez que a maioria dos projetos não estão prontos para recebê-los sem precisar de adaptações simples ou profundas.

Figura, portanto, no cenário da Educação Superior (incluindo os projetos em EAD), uma diversidade de fatores intelectuais, distúrbios de aprendizagem, distúrbios de motricidade, físicos, emocionais que acometem os alunos, além das preferências pessoais que fazem do ambiente de aprendizagem um desafio para os educadores.

Nesse cenário, o material didático tem figurado como um dos mais importantes recursos utilizados para se alcançar os princípios e os objetivos propostos para o processo de ensino-aprendizagem (BRASIL, 2007). Contudo, segundo o ABRAEAD (2010, p. 88), a aprovação pelos discentes dos recursos didáticos utilizados nos cursos EAD brasileiros não é unânime, especialmente, entre os alunos evadidos, os quais, dentre outros fatores, "consideraram o material muito difícil ou [...] não aprovaram os recursos oferecidos pela instituição". Portanto, dada a sua relevância, é fundamental que o processo editorial do material didático, o qual se estende desde a concepção e elaboração até à arte final e distribuição por meio de diferentes recursos tecnológicos, seja persistentemente aperfeiçoado na busca de atender às necessidades dos discentes que participam ou podem vir a participar ativamente do referido processo de aprendizagem em cursos superiores.

Isso evidencia a necessidade de atentarmos para a qualidade dos materiais ao planejarmos e executarmos um curso superior com algumas disciplinas ou completamente na modalidade EAD, uma vez que esse fator também exercerá influência direta na qualidade docursocomo um todo.

Partindo dessa proposta, projetos pautados em teorias que considerem e respeitem os diferentes ritmos de aprendizagem, perfis cognitivos ecompetências pessoais para uma construção ativa e dinâmica do conhecimento pelo discente, defendem que é preciso que estejamos atentos, ao planejar, elaborar, divulgar e distribuir materiais didáticos, para requisitos como: acessibilidade, adaptabilidade, preferência, motivação, dentre outros.

Além disso, a LDB preconiza que o ensino deve ser realizado com base em princípios de igualdade de condições para o acesso e permanência. 
Transpassando a legislação e permeando todos os níveis e fases da educação, o paradigma de inclusão propõe partir da análise de como tem funcionado o nosso sistema educacional, para identificar as barreiras existentes na aprendizagem dos alunos, com vista às providências políticas, técnicas e administrativas que permitam enfrentá-las e removê-las (WERNECK, 1997; CARVALHO, 2003).

Nesse contexto e em busca de soluções, especialmente no que se refere ao material didático, verifica-se em várias nações, especialmente em países com maior tradição na EAD, como os Estados Unidos, a Inglaterra e o Canadá, inúmeros projetos pautados no DU para a Aprendizagem, os quais têm sido apontados pela literatura como solução viável, dentre outros, para o problema da acessibilidade e adaptabilidade (ROSE; MEYER, 2002; 2006).

O DU para Aprendizagem pode ser definido como um conjunto de princípios para o desenvolvimento de currículo que oferece a todos os indivíduos igualdade de oportunidades para aprender.Ele fornece um modelo para a criação de objetivos de ensino, métodos, materiais e avaliações que atendem e ofereçam possibilidades efetivas de sucesso no processo de aprendizagem para todos, por intermédio de abordagens bastante flexíveis que podem ser personalizadas e ajustadas às necessidades individuais (NCU, 2012).

Verifica-se na literatura nacional, propostas e trabalhos que tratam sobre dificuldades/preferências de aprendizageme a importância de iniciativas inclusivas, pensadas aqui de forma ampla, para garantir a acessibilidade e sucesso da aprendizagem, os quais são relevantes e tem figurado como pontos de partida para pesquisas futuras.

No entanto, há escassez de iniciativas e projetos concluídos que consideram, em sua totalidade, as especifidades dos educandos brasileiros de acordo com nossos perfis e aspectos pessoais, culturais, sociais etc., ou ainda, que avaliam os efetivos impactos de aplicações teóricas, tais como a do DU para a Aprendizagem, no processo de aprendizagem, em suas variadas dimensões, como por exemplo a Motivação e a Autoeficácia para a Aprendizagem, para encontrar caminhos que viabilizem o aumento da adaptabilidade ao método EAD e o desejo momentâneo e continuado em perseverar no processo de aprendizagem. 
Emergem, desse modo, um questionamento que representa o problema da presente pesquisa: a incorporação dos princípios do DU para a Aprendizagem pode melhorar os índices Motivação e a Autoeficácia para a Aprendizagemdos alunos brasileiros inscritos nos cursos superiores na modalidade EAD?

Oobjetivo do presente trabalho é, portanto, avaliar o impacto da aplicação dos princípios do DU para a Aprendizagem no desenvolvimento do material didático utilizado em cursos Superiores EAD em relação às dimensões de Motivação e Autoeficácia para a Aprendizagem.

Em busca do objetivo proposto, optou-se pelo embasamento teórico a partir do modelo de DU para a Aprendizagem americano do NCU (CAST, 2011; ROSE; MEYER, 2002; 2006; WAKEFIELD, 2011).

Realizou-seno material didático utilizado pelos alunos brasileiros daEducação Superior, a implementação de quatro propostas didáticas baseadas em determinadas diretrizes de dois, dos três princípios do DU para a Aprendizagem.

Ademais, buscou-se partir das contribuições das Neurociências e da Psicologia para escolha de duas dimensões da aprendizagem a serem mensuradas: a 'Motivação', conceituadacom base em diferentes abordagens sustentadas por teóricos como Piaget (1982), Vygotsky (1991; 1993), Azenha (2002), Boruchovitch (2001) etc. e mensurada a partir da Escala de Motivação Acadêmica (VALLERAND et al., 1992; 1993) e a 'Autoeficácia para a Aprendizagem', entendida a partir da Teoria Social Cognitiva proposta por Bandura (1997) e verificada por meio da Escala de Autoeficácia Acadêmica Percebida, instrumento elaborado de validado por De Sá (2002; 2006).

O referencial teórico que oferece sustentação à presente pesquisa pode, portanto, ser assim sintetizado:

Figura 1Referencial de sustentação teórica da pesquisa.

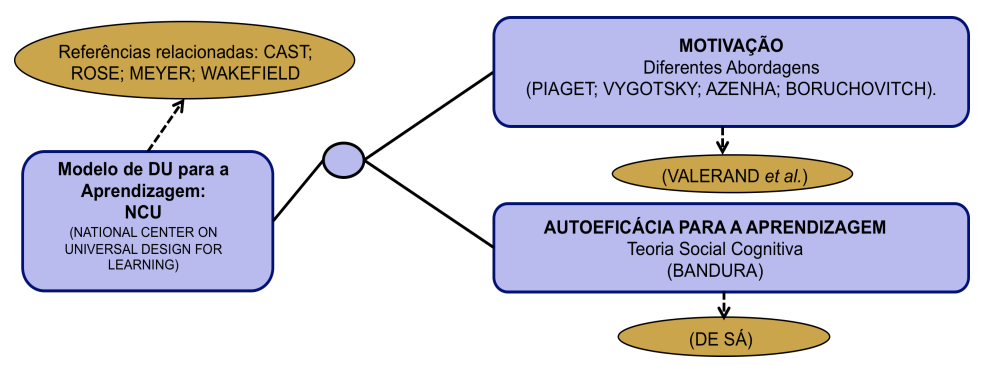

Fonte: Acervo pessoal. 
Salienta-se que a presente pesquisa foi pautada em um projeto que busca apresentar uma proposta de elaboração de materiais didáticos, baseada em um modelo mais sensível às possibilidades, preferências e habilidades individuais dos alunos brasileiros, procurando possibilitar/fomentar o sucesso de todos, sempre que possível, sem necessidade de adaptação ou design especial para as pessoas com deficiência.

Figura 2 Síntese do projeto da pesquisa.

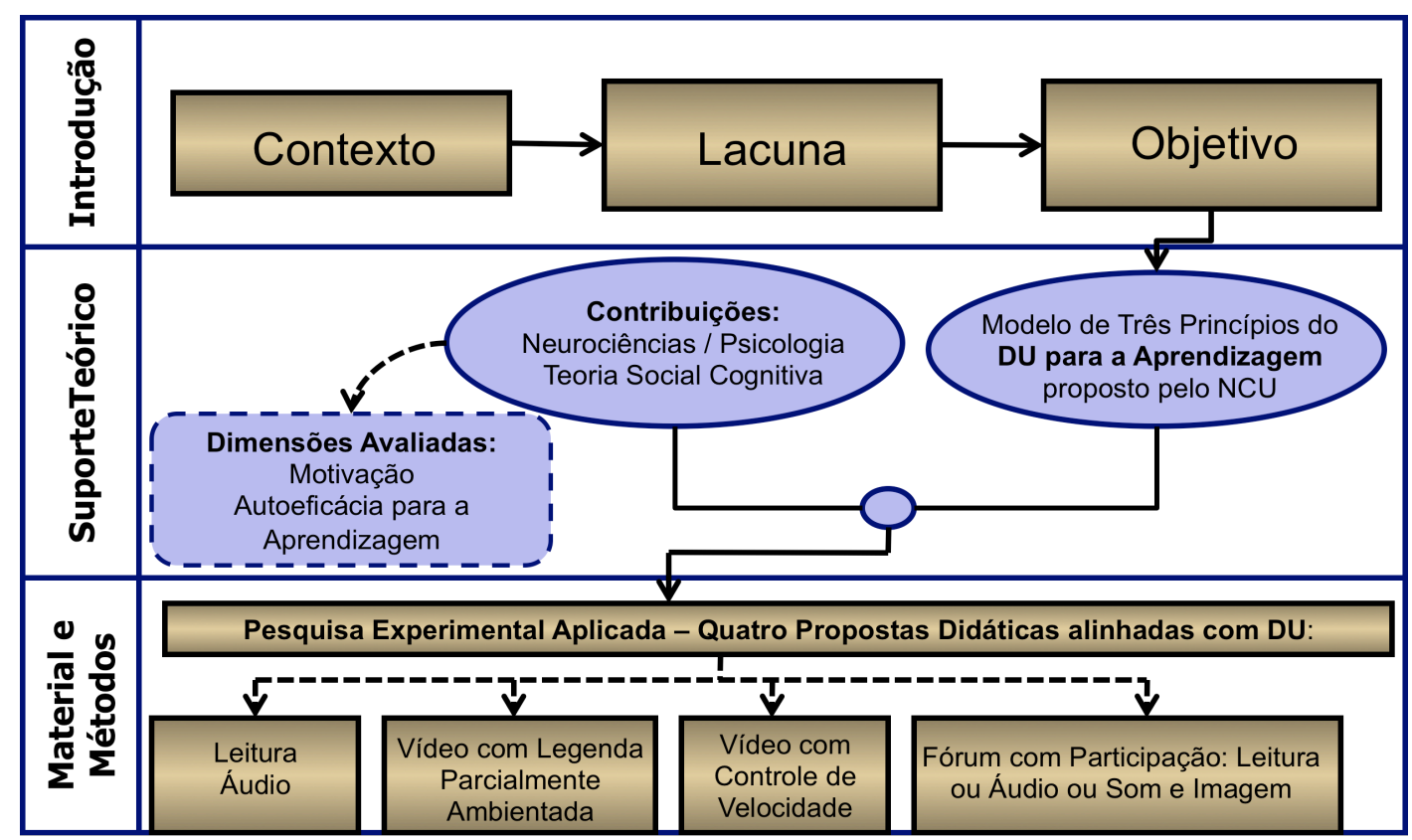

Fonte: Acervo pessoal.

Ao pesquisar o DU para a Aprendizagem, a intenção é de buscar opções que respeitem as necessidades/preferenciais e desenvolva as potencialidades individuais de todos os alunos.

\section{1 - Organização do Trabalho}

Com vistas a esclarecer a abordagem do conteúdo, segue uma breve descrição sobre os capítulos que compõem esta pesquisa: no presente capítulo, é realizada uma descrição prévia do contexto e do objetivo desta pesquisa, suas justificativas, seu projeto, bem como dos temas que representam os objetos de estudo deste trabalho.

Já o Capítulo 2 apresenta a Educação Superior no Brasil, seu posicionamento no sistema educativo brasileiro, legislação, evolução histórica, tendências e perspectivas. 
Dando prosseguimento, o Capítulo 3 traz uma breve descrição da modalidade EAD no Brasil, seu potencial para democratização do ensino com qualidade, a forma como está concebida, as teorias que oferecem respaldo teórico-científico para a prática, dentre outras questões.

Com isso, o Capítulo 4 avançará sobre o material didático, seu papel e a importância que atualmente tem sido atribuída a este recurso. Seguirá com a descrição do processo de concepção, planejamento, execução, finalização, multiplicação e distribuição desse recurso, destacando questões relacionadas à sustentabilidade em suas várias dimensões.

No Capítulo 5, investiga-se o DU para a Aprendizagem começando pela contextualização histórica, passando pela descrição, refletindo sobre a inclusão, até o reconhecimento de suas limitações e potenciais para incorporação no processo de editoração dos materiais didáticos.

O sexto capítulo abre uma discussão sobre os conceitos de Motivação e Autoeficácia para a Aprendizagem.

Seguindo, no Capítulo 7 são relatadas as etapas, fases da aplicação, amostra, dentre outros dados relacionados à metodologia aplicada para concretização do experimento.

No capítulo seguinte, são explicitados e analisados os resultados alcançados. Nele discute-se a efetiva contribuição proporcionada pela incorporação dos princípios do DU para a Aprendizagem no material didático.

Para finalizar, no Capítulo 9 são apresentadas as considerações finais sobre as dimensões teórico-empíricas do trabalho realizado, com apresentação de alguns de seus pontos e contrapontos, bem como com a sugestão de outros estudos que venham a subsidiar novas descobertas sobre a temática.

Acredita-se que a proposta de incorporação do conceito do DU para a Aprendizagem no processo de editoração do material didático, tornando-o autoadaptável e capaz de responder às interações do usuário, apresenta potencial para viabilizar e tornar factíveis os ideais filosófico-didáticoeducacionais esperados para este recurso, permitindo, junto a outros fatores, mais do que a acessibilidade, mas o sucesso de todos por meio da modificação e adaptações no processo ensino-aprendizagem (CAMPOS, s/d.). Além disso, objetiva-se ainda caminhar rumo ao paradigma da educação que prevê 
ambientes regulares de ensino, em todos os seus níveis, cada vez mais capazes de incluir.

Entende-se, como ponto de partida, que o DU para a Aprendizagem no processo de editoração do material didático irá requerer uma equipe multidisciplinar dedicada, disposta a assumir riscos e a inovar, além do desenvolvimento e sustentabilidade de uma infraestrutura tecnológica, apoiada pela diretoria da IES e por todos os componentes e agentes do processo em pauta, os quais, por esta razão, também representarão objetos de estudo. 


\section{Capítulo 2 - Educação Superior}

As inúmeras, constantes e rápidas mudanças sociais, políticas, econômicas e culturais da sociedade brasileira contemporânea, as quais, por conseguinte, levam às mudanças de valores e crenças pessoais e culturais têm contribuído para uma nova visão sobre o mundo, no qual a Educação Superior tem se consolidado como uma das mais respeitadas instituições sociais.

Reconhece-se que para compreender a importância das incorporações de novas metodologias no trabalho pedagógico da Educação Superior é preciso retomar o contexto das mudanças ao longo dos tempos, seus avanços, bem como as estruturas ideológicas fundantes que a marcaram, pois, como afirmou um pensador anônimo, "a história é um profeta com os olhos voltados para trás" (FUNDAÇÃO BIBLIOTECA NACIONAL, 2011).

Nesse ensejo, o objetivo do capítulo que ora se inicia é o de descrever brevemente quando, como e porque a Educação Superior passou a fazer parte do sistema educativo brasileiro, quais evoluções e valores fizeram parte de sua história, sua legislação regulamentatória, caracterizações, estrutura, bem como situação atual, tendências e perspectivas.

\section{1 - Educação Superior no Sistema Educativo Brasileiro}

A lei maior do Brasil preconiza que a educação é um direito de todos e dever do Estado e da família, a qual precisa ser incentivada e promovida com o apoio da sociedade, visando ao pleno desenvolvimento da pessoa, ao seu preparo para o exercício da cidadania e à qualificação para o trabalho (BRASIL, 1988). Portanto, o ensino deverá ser ministrado com base nos princípios de igualdade de condições para o acesso e permanência, com gratuidade do ensino público e coexistência de instituições privadas e públicas (BRASIL, 1994).

Assim sendo, tanto a federação, quanto os Estados e Municípios e a iniciativa privada têm se dedicado a atuar no nível superior. Ademais, o sistema educativo brasileiro previsto na CF, foi redefinido pela nova LDB, deixando a Educação Superior, assim situada: 
Figura 3Estrutura do sistema educativo brasileiro.

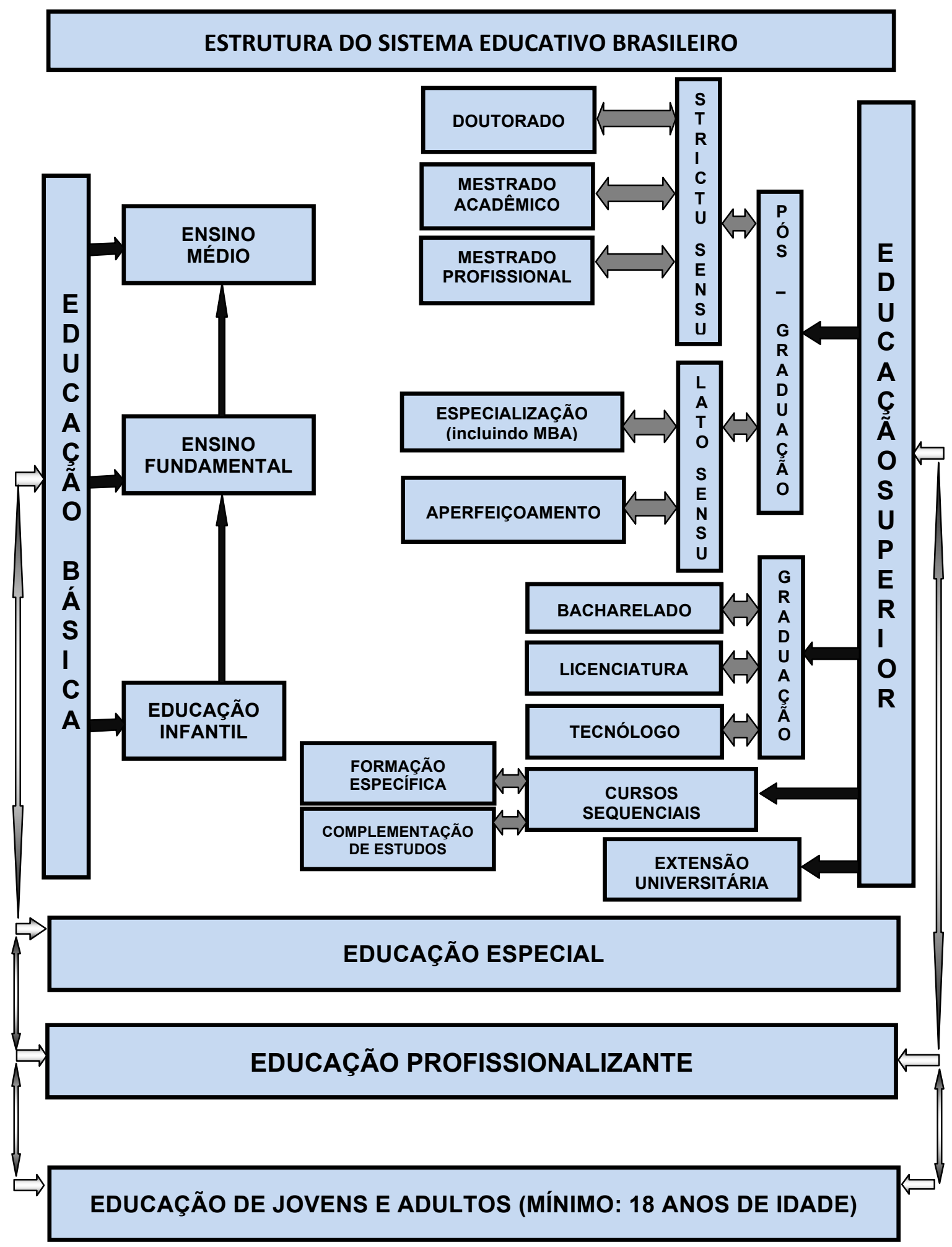

Fonte: Acervo pessoal.

Ainda segundo a LDB, a Educação Superior, considerando a forma como se situa e interage no sistema educativo brasileiro explicitado na Figura 3 , tem por finalidade fomentar o pensamento reflexivo, o espírito científico e a 
criação cultural; diplomar pessoas em diferentes áreas para atuação, capacitando para atuação profissional e para o desenvolvimento da sociedade; impulsionar a investigação científica e o trabalho de pesquisa; promover e comunicar os conhecimentos científicos, técnicos e culturais; incentivar e oferecer condições para concretização do constante aperfeiçoamento cultural e profissional; possibilitar o reconhecimento dos problemas atuais, especialmente os nacionais e regionais, prestando serviços, promovendo a extensão e estabelecendo uma relação de reciprocidade (BRASIL, 1996).

Para atingir as referidas finalidades, existem diferentes tipos de IES, conforme preconiza o Artigo 12 do Decreto 5.773/2006 (BRASIL, 2006): “I faculdades;II - centros universitários; e III - universidades".Nas faculdades (ou instituições equiparadas), a oferta de cursos superiores dependerá de autorização expressa do Ministério da Educação. Já os centros universitários, criados por credenciamento de IES, são pluricurriculares e gozam de algumas prerrogativas de autonomia atribuídas às universidades. Finalmente, as universidades além de terem autonomia didático-científica, administrativa, patrimonial e de gestão financeira também são pluridisciplinares e se caracterizam, dentre outras características, por garantirem atividades de ensino, pesquisa e de extensão. A autonomia teste tipo de IES possibilita ainda a criação, organização e extinção de cursos (incluindo remanejamento, aumento ou diminuição de vagas), programas e atividades em geral (BRASIL, 1988; BRASIL, 1996; BRASIL, 2006).

Verifica-se, dessa forma, que a Educação Superior no Brasil abarca um sistema diversificado e complexo de IES públicas e privadas, devidamente credenciadas com os seguintes cursos reconhecidos e autorizados (BRASIL, 1996):

- de extensão universitária, para discentes que atendam aos requisitos estabelecidos pela IES em que pretendem ingressar.

- sequenciais abertos (distintos níveis de abrangência) por campo de saber, podendo ser para formação específica ou para complementação de estudos.

- de graduação (licenciaturas, bacharelados e tecnólogos) para alunos que tenham sido aprovados em processos seletivos e que tenham concluído o ensino médio ou equivalente. 
- de pós-graduação strictu sensu (mestrado e doutorado) e lato sensu (especialização, MBA e outros), cursos de aperfeiçoamento (Parecer CNE/CES n. 254/2002; Parecer CNE/CES n. 263/2006) para estudantes que atendam às exigências da IES e que sejam diplomados em cursos de graduação.

A regulamentação das IES, bem como de seus cursos, é realizada pelos agentes institucionais seguindo legislação específica:

Quadro 1 Principais dispositivos regulamentados pelos decretos, portarias e resoluções da Educação Superior.

\begin{tabular}{|c|c|}
\hline DISPOSITIVOS & DECRETOS E PORTARIAS \\
\hline $\begin{array}{l}\text { Procedimentos e critérios } \\
\text { paraautorização e reconhecimento } \\
\text { decursos (dentro e fora da sede) }\end{array}$ & $\begin{array}{l}\text { Decretos n. 2.406/97 e 5.773/06; } \\
\text { Portarias n. 612/99, 639/97, 640/97, } \\
\text { 641/97, 752/97, 80/97, 877/97,946/97, } \\
971 / 97,1.679 / 99,2.175 / 97,2.297 / 98 \\
\text { e 2.402/01. }\end{array}$ \\
\hline $\begin{array}{l}\text { Procedimentos e critérios } \\
\text { paracredenciamento } \\
\text { erecredenciamento de IES }\end{array}$ & $\begin{array}{l}\text { Decreto n. 5.773/06; } \\
\text { Portarias n. 302/98, 637/97, 639/97, } \\
\text { 640/97, 752/97, 946/97, 1.679/99, } \\
\text { 2.040/97, 2.041/97 e 2.297/98; } \\
\text { Resolução CES/CNE n 10/02. }\end{array}$ \\
\hline $\begin{array}{l}\text { Procedimentos operacionais para } \\
\text { avaliação doscursos, programas e } \\
\text { odesempenho individual de } \\
\text { IESeórgãos responsáveis }\end{array}$ & $\begin{array}{l}\text { Decretos n. } 2.406 / 97 \text { e } 5.773 / 06 \text {; } \\
\text { Portarias n. 302/98, 972/97 e } \\
\text { 2.297/98. }\end{array}$ \\
\hline $\begin{array}{l}\text { Organização da Educação Superior } \\
\text { (Natureza jurídica, acadêmica } \\
\text { emantenedoras das IES) }\end{array}$ & $\begin{array}{l}\text { Decretos n. } 2.406 / 97 \text { e } 5.773 / 06 \\
\text { Portarias } 2.040 / 97 \text { e } 2.041 / 97\end{array}$ \\
\hline Entidades Mantenedoras das IES & Decreto $n^{\circ} 5.773 / 06$. \\
\hline
\end{tabular}

Fonte: Adaptado de SOARES, M. S. A. et al. A educação superior no Brasil. Disponível em $<$ http://unesdoc.unesco.org/images/0013/001393/139317por.pdf>. Acesso em: 12 nov. 2012, p. 60.

Para a Educação Superior, cada ano letivo deverá ter duzentos dias de trabalho acadêmico efetivo, os quais precisam se iniciar com apresentação das informações sobre os cursos oferecidos, seus programas, duração, requisitos, qualificação dos docentes, recursos disponíveis, critérios de avaliação e demais componentes curriculares. No final desse período, a IES tem obrigação de cumprir todas as condições previamente comunicadas (BRASIL, 1996).

\section{2 - Evolução Histórica}

Refletir sobre o percurso histórico daEducação Superior no Brasil nos possibilita reconhecer sua capacidade adaptativa em relação às demandas da 
sociedade brasileira, uma vez que, mesmo nos momentos em que sua resposta foi demorada, sempre buscou efetivar um modelo de organização e funcionamento com configurações capazes de responder às necessidades sociais. A ideologia, o perfil e a missão das IESsempre foram influenciados pelo debate ideológico e cultural de cada época, matizando seus conceitos, teorias e práticas (CRESPO, 2003).

Desde a gênese daEducação Superior no cenário brasileiro até os dias atuais, verifica-se uma expectativa da sociedade por uma resposta adequada às suas necessidades. Além disso, espera-se que as IES detenham capacidade de ação, e não somente de reação, perante os constantes desafios e tendências (SCOTT, 1995).

No entanto, há pensadores que defendem a ideia de que a formação profissional superior, bem como a estrutura de ensino nacional não tem apresentado historicamente condições de acompanhar, de forma plena e total, as exigências de mudanças ocorridas no mercado de trabalho. $O$ fato em questão fica ainda mais evidenciado se considerarmos o distanciamento que por vezes pode ser identificado entre a velocidade das transformações nos vários campos do conhecimento tecnológico-científico e o conteúdo das disciplinas curriculares (FERREIRA, 2004; WOODS JR., 2000).

Ressalta-se, neste contexto, que uma das finalidades da Educação Superior é, justamente, a de representar a etapa final da formação profissional e cultural do discente, ajudando-o a assumir uma postura de superação do senso comum, de investigação científica, produção e difusão do conhecimento (PALDÊS, 1998). Espera-se, dessa forma, que as IES se movam cada vez mais em busca de atingir esses anseios da sociedade, uma vez que é justamente a capacidade de se ajustar, aliada a de inovar, que garantirá a essas instituições longevidade e condições de resistir aos desgastes de cada momento histórico, mantendo sua identidade e características, bem como sua capacidade de mudança (SCOTT, 1995).

A síntese da evolução histórica da Educação Superior no Brasil apresenta-se nos parágrafos a seguir, os quais foram baseados nas ideias de Aranha (1996), Romano (1999), Cunha (2000) e Hilsdorf (2002).

No Período colonial existiam somente cursos superiores de Filosofia e Teologia implantados e mantidos pelos Jesuítas, uma vez que Portugal impedia 
a implantação de IES em suas colônias, temendo que a difusão do conhecimento pudesse contribuir para movimentos de independência.

A partir de 1808, a chegada da família real portuguesa ao Brasil marca o início efetivo da Educação Superior em nosso país. Nesse ínterim, foram implantadas IES formais que, a princípio, ofereceram cursos de engenharia (academia militar), medicina (cátedras de cirurgia e anatomia) e belas artes. Os referidos cursos eram gratuitos e mantidos com impostos cobrados sobre os produtos exportados do reino e das colônias ("Quinto da Coroa").

No Brasil Império, a expansão da Educação Superior ocorreu lentamente com o surgimento de cursos isolados em várias áreas, devido ao modelo econômico predominantemente - agroexportador - que não demandava profissionais com formação superior.

Com a proclamação da República, verifica-se um aumento significativo das reflexões sobre os mais variados temas ligados à Educação, especificamente em relação às universidades.Nesta época, os deputados constituintes passaram a buscar a criação de IES em diferentes estados brasileiros, contudo, seus anseios esbarraram em problemas financeiros, uma vez que a maior parte da receita era destinada ao pagamento de dívidas. Apesar das citadas dificuldades, a Constituição da República de 1891 descentralizou a oferta da Educação Superior fazendo com que os governos estaduais e a iniciativa privada passassem a implantar e manter suas próprias IES.Surgem, ainda, pela primeira vez no Brasil, em decorrência da crescente urbanização e industrialização, ações planejadas que objetivavam organizar a educação nacional.

Com a Era Vargas, os decretos de Francisco Campos passam a imprimir uma nova orientação, na qual são enfatizados: o interesse e o fomento à pesquisa, maior autonomia administrativa e didática, a difusão da cultura, bem como as ações que venham a beneficiar a comunidade.

A partir de 1930 são criados os ensinos comercial e secundário, o Conselho Federal de Educação e as universidades; todos a partir de um percentual da arrecadação dos impostos destinados para financiar a educação.

A partir de 1940, surgiram as primeiras universidades privadas do país: as Faculdades Católicas no Rio de Janeiro, as quais só são reconhecidas pelo Estado em 1946. Até então, para o reconhecimento de uma IES, era exigida a 
criação uma lei estadual, e a nomeação do reitor era feita pelo Estado. Outra característica marcante deste período foi a criação da União Nacional dos Estudantes (UNE) e de seu estatuto, que defendia a universidade aberta para todos, o exercício da liberdade de pensamento, a diminuição das taxas de exame e matrícula, a imprensa e tribuna, a cátedra, a elaboração dos currículos com a participação dos discentes, a independência das IES diante do Estado (dirigentes eleitos por docentes e discentes e representados por um conselho universitário paritário), a criação de monitorias e estágios e a livre associação dos estudantes dentro das IES.

Este período também foi marcado, em decorrência do processo de industrialização, pela ênfase no ensino profissionalizante: criam-seo Serviço Nacional de Aprendizagem Comercial (SENAC) e o Serviço Nacional de Aprendizagem Industrial (SENAI), além do curso de formação docente de professores, trazendo otimismo quanto à valorização da carreira docente, que de fato não se concretizou.

Com o Estado de direito (fim do Estado Novo), a Constituição de 1946 passa a refletir a redemocratização do país e a garantir direitos individuais de expressão, pensamento e reunião. Contudo, a educação continua igual: o ensino médio subdividido em profissional, para os trabalhadores; e em propedêutico, para a elite, o que acabava por determinar quem efetivamente era conduzido para a Educação Superior.

Depois, a volta de Getúlio Vargas ao poder (1950-1954), proporcionou algumas medidas que foram adotadas para equivalência dos cursos profissionais a secundários, cujas medidas foram ampliadas na Lei de Diretrizes e Bases da Educação Nacional de 1961. Para atender à expansão do Ensino Médio e, consequentemente, ao aumento da demanda pelaEducação Superior, o governo federal estabeleceu:

a) a criação de novas faculdades onde não as havia ou onde só existiam instituições privadas;

b) a gratuidade de fato dos cursos das instituições federais de Ensino Superior, mesmo a legislação prevendo a cobrança de taxas;

c) a 'federalização' das faculdades estaduais e privadas, reunindo-as, posteriormente, em universidades 
custeadas e controladas pelo MEC (CUNHA, 2000, p. 171).

Portanto, nesta fase, verifica-se a ampliação da Educação Superior gratuito, a criação das universidades federais e do Instituto Tecnológico de Aeronáutica (ITA), o qual, ao inovar com a implantação de um modelo americano, acabou por influenciar a modernização da Educação Superior no Brasil, de maneira especial, com a criação da Universidade de Brasília.

Além disso, em decorrência da necessidade de estimular a formação e a capacitação do docente-pesquisador (especialmente na USP) e de modernizar as universidades, surgiram a Coordenação de Aperfeiçoamento de Pessoal de Nível Superior (Capes), a Sociedade Brasileira para o Progresso da Ciência (SBPC) e o Conselho Nacional de Desenvolvimento Científico e Tecnológico (CNPq).

Já em 1961, depois de um processo conflituoso e extenso, foi aprovada a Lei de Diretrizes e Bases da Educação Nacional n. 4.024, a qual possibilitou grandes inovações para a educação e para a cultura e fomentou, com o apoio de intelectuais, da UNE e de movimentos populares, uma campanha em defesa da escola pública.

Com o Golpe Militar em 1964, a ideologia e ações construídas, até então, foram desativadas. Nesta fase, o regime militar vetou o monopólio do ensino pelo Estado, apoiando a iniciativa privada; mudou a Lei de Diretrizes e Bases da Educação Nacional n. 4.024 para atrelar nosso sistema educacional ao modelo econômico norte-americano; aprovou a lei da Reforma Universitária (Lei n. 5.540/68) que unificou as faculdades em universidades; tornou o vestibular classificatório e o unificou; acabou com a cátedra e criou o sistema de créditos (permitindo matrícula por disciplina). Muitas dessas iniciativas exercem, até hoje, influência naEducação Superior, dentre elas: estrutura fundada em departamentos reunidos (extinção das cátedras), unidade de funções de ensino e pesquisa, universalidade de campo (cultivo das áreas fundamentais dos conhecimentos humanos), flexibilidade de métodos e critérios com vistas a respeitar as diferenças individuais e as peculiaridades dos alunos, sistema de créditos, institucionalização da pós-graduação strictu sensu, vestibular classificatório e unificado, indissociabilidade entre ensino e pesquisa etc. 
Ao defender o princípio da indissociabilidade entre ensino e pesquisa para orientar a reorganização da universidade brasileira, a mencionada lei possibilitou a oposição de interesses acadêmicos, até então hegemônicos, a outros interesses dessa mesma natureza que emergiam e buscavam impor-se no âmbito do Ensino Superior. Orientada por uma mentalidade assentada no binômio racionalidade e produtividade, a universidade brasileira passava a ser entendida através da relação custo $x$ benefício, produtividade e o mínimo de investimento [...] (SOUSA, 2003, p. 16-17).

O regime militar ainda alterou a localização geográfica das IES públicas, que antes eram situadas nas regiões centrais das cidades, para os campi no subúrbio, com o objetivo de evitar ou atenuar a militância política dos estudantes, ao passo que as IES particulares seguiram o caminho contrário. Salienta-se que, mesmo com as citadas mudanças, persistiu a seletividade: IES privadas de nível discutível para a população pobre; e públicas e/ou privadas de alto nível para a elite.

A partir da década de 90, descobre-se que, ao contrário do que se acreditava, mais de $60 \%$ dos estudantes inscritos naEducação Superior, público e privado, eram provenientes de famílias com renda superior a 10 salários mínimos, informação que desmistificou a ideia de que eram os mais pobres quem frequentavam o ensino privado. Evidenciou-se, assim, a incidência simultânea de problemas sociais e a deficiência na educação básica.

Outras características marcantes deste momento histórico foram: os sucateamentos ocasionados por cortes nas verbas, o aumento vertiginoso do número de IES particulares (incluindo a partir da destinação de verbas pública), a ausência de uma política efetiva de assistência estudantil, a insuficiente realização de concursos públicos para funcionários técnico-administrativos e docentes, a aprovação da atual LDB (Lei n. 9394/96) e a criação do PNE, a ampliação dos projetos de EAD, o incentivo à privatização, a entrada de recursos não-públicos para manter as atividades próprias das IES etc. Ainda em 1996, com o objetivo de consolidar ainda mais a privatização da universidade pública brasileira, descomprometendo o Estado do seu financiamento, constituíram-seos pilares da reforma universitária: autonomia 
universitária, exame nacional de cursos (provão), avaliação Institucional e melhoria geral do ensino.

No início do século XXI, as ações iniciadas na década de 90 ainda não tinham sido implementadas na sua totalidade, entretanto, já foram incrementadas com: ofertas regidas totalmente pelas demandas mercadológicas, vinculação da universidade aos setores produtivos, diminuição do financiamento estatal para as IES públicas e ampliação das parcerias e convênios com as privadas, legalização de fundações privadas nas universidades (Decreto n. 5.205/2004), flexibilização de formas de contratação (CLT e contratos temporários), o surgimento do ProUNI (Projeto Universidade para Todos), do Projeto de Emenda Constitucional (PEC n. 217) que instaurouo PDI, o Sistema Nacional de Avaliação do Ensino Superior - SINAES (Lei n. 10.861, de 14 de Abril de 2004) etc.

\section{3 - Tendências e Perspectivas}

As perspectivas e tendências daEducação Superior têm apontado para modalidades de ensino-aprendizagem que priorizam a utilização de tecnologias de última geração. Contudo, reconhece-se que as tecnologias (testadas ou novas) podem apresentar desvantagens e vantagens, assim, a ênfase para caracterização da nova universidade é atribuída às modalidades pedagógicas de ensino e aprendizagem (CENA, 2000; MONTEIRO, COSENTINO, MERLIN, 2000; WOODS JR., 2000).

Ademais, verifica-se uma nova configuração caracterizada pela comunicação (construção de significado mútuo para a construção de novos conhecimentos), conexão (rápida e flexível) e colaboração (resolução conjunta de problemas) (CAMPOS et al. apud MONTEIRO; COSENTINO; MERLIN, 2000). O referido contexto educacional é, ainda, altamente influenciado pela interatividade no processo de aprendizagem, o que tem promovido mudança de regras e a necessidade de desenvolver competências ou habilidades para gerir o processo de construção do conhecimento e para o trabalho em grupo, contando com o apoio massivo de meios de comunicação (MASON, 1998).

A Educação Superior Brasileira necessita de constantes reformas qualitativas em todas as suas dimensões: pedagógica, administrativa, infraestrutura, atuação dos profissionais, posicionamento dos discentes, no 
sentido de aprimorar a educação de acordo com as demandas a ela atribuídas, as quais vão sendo constantemente alteradas a cada geração e configuração social.

Finalmente, destaca-se que a Educação Superior é vista no Brasil como parte integrante da história da sua sociedade. Esse tema tem despertado cada vez mais interesse e a evolução dessas instituições pode contribuir de forma significativa para a história do progresso da nossa nação! 


\section{Capítulo 3 - EAD}

Os sistemas educativos, assim como a cultura e as relações de trabalho, têm sofrido profundas alterações com o advento das TIC's, as quais são responsáveis por provocar significativas tensões e evoluções nesses contextos. Observa-se, diante dessa realidade, um déficit de socialização e formação, ocasionado pelos sistemas educativos contemporâneos, que foram fundados nos modelos dos séculos XIX e XX e, portanto, em vários aspectos, não respondem mais às exigências atuais (TEDESCO, 1995; 2004; BRUNNER, 2004).

Com o objetivo de adaptar a educação às demandas dessa nova sociedade, inúmeros teóricos defendem que, as soluções apontadas têm sido baseadas em dois grandes eixos: a educação continuada e a EAD.

A nova conjuntura socioeconômica instalou um imperativo de que a educação é processo permanente, deixando de ser característica de uma fase específica da vida, para se tornar uma necessidade constante. O profissional precisa tornar-se um incansável pesquisador, reinventar-se a cada dia, aceitar os desafios e a imprevisibilidade da época para se aperfeiçoar cada vez mais (BRUNNER, 2004; GOUVÊA, OLIVEIRA, 2006; KENSKI, 2006).

$\mathrm{Na}$ perspectiva de gerenciar algo tão complexo e incerto, as instituições, dentre outras necessidades, precisam manter grande competência em P\&D, detectar sinais do ambiente sobre potencial de mudança, selecionar oportunidades de acordo com seu contexto e estratégia global, implementar ideias, executar projetos inovadores e aprender constantemente com erros para reinventar seus processos (TIDD, BESSANT; PAVITT, 2008).

$O$ desenvolvimento das TIC's neste ambiente paradoxal e complexo encontrou na EAD uma alternativa viável e capaz de proporcionar incontáveis possibilidades de expansão das ofertas educacionais em processo continuado, especialmente pelo fato de a EAD ser flexível e se utilizar de mediações tecnológicas que articulam o centro de formação, as inter-relações de circunstâncias e a adequação às mediações utilizadas para se aproximar dos contextos reais de inserção profissional (SABA, 2003; CORRÊA et al., 2006).

A escolha da EAD ainda é apontada como meio de dotar as instituições educacionais de condições para atender às novas demandas de ensino e 
aprendizagem e de treinamento ágil e de qualidade superior, especialmente devido à sua capacidade de atender, com eficácia, eficiência e qualidade, aos anseios de universalização.

Ademais, a EAD, com suas especificidades, assim como na educação presencial, efetiva a construção de conhecimentos já elaborados, fomenta a geração de novos conhecimentos por meio de programas orientados de pesquisa, bem como oferece possibilidades diferenciadas de relacionamentos pessoais.

A EAD é também uma opção válida por oferecer, com o uso das TIC's e comunicação, espaços virtuais para disponibilização de conteúdos, espaços de interação entre profissionais e professores, possibilitando adaptações e customizações, abrangendo as distintas formas de estudo e de comunicação em todos os níveis.

Atualmente, devido a essas e outras peculiaridades, verifica-se um grande público interessado por EAD, do qual se destacam os alunos adultos que direcionam esforços para ganhar certo conhecimento ou habilidade, bem como para planejar sua aprendizagem, forma e ritmo de estudo, intercalandoos com as atividades pessoais. O diferencial procurado por esses indivíduos são as interações e as trocas de experiências com agentes de áreas afins ou distintas, buscando sempre ter o conhecimento de situações de trabalho ou incremento de repertório de atuação em suas atividades profissionais (NUNES, 2010; POSSAMAI, 2003).

\section{1 - Conceituação e Caracterização}

A EAD, ou ensino a distância como também ficou conhecida, tem sido assim definida:

- Dohmem (1967apud NUNES, 2010): forma de autoestudo sistematicamente organizada, na qual o discente se instrui por intermédio de material de estudo, do acompanhamento e da supervisão de um grupo de docentes, que se utilizam da aplicação de meios de comunicação capazes de vencer longas distâncias.

- Peters (1973): método racional de partilhar atitudes, habilidades e conhecimentos, por intermédio do uso extensivo de meios de 
comunicação, bem como da aplicação da divisão do trabalho e de princípios organizacionais, de maneira especial, com o objetivo de reproduzir materiais didáticos técnicos de alta qualidade que permitam ensinar um grande número de estudantes ao mesmo tempo. Pode ser entendida também como uma forma industrializada de ensinar e aprender.

- Holmberg (1985): distintas formas de estudo em todos os níveis de ensino, cujos discentes não estão sob a contínua e imediata supervisão de tutores presentes em salas de leitura ou no mesmo local, mas que são beneficiados por planejamento, guia e acompanhamento de seu processo de aprendizagem.

- Moore (1989): família de métodos instrucionais em que as ações dos docentes são executadas a parte das ações dos discentes, incluindo situações continuadas que podem ser realizadas na presença dos estudantes. A comunicação e a construção de conhecimentos é, portanto, facilitada e mediada por meios mecânicos, impressos, eletrônicos, entre outros.

- Keegan, Holmberg, Moore (1991): conjunto de estratégias educativas citadas como: educação por correspondência (Reino Unido) ou ensino a distância (Open Universitydo Reino Unido); estudo em casa ou home study (Estados Unidos); estudos externos ou externalstudies (Austrália); Télé-enseignement (em francês); Fernstudium/Fernunterricht (em alemão); educación a distância (espanhol) e teleducação (em português).

- Romiszowski (1993, p. 32): "qualquer metodologia de ensino que elimina as barreiras da comunicação criadas pela distância ou tempo".

- Willis (1994): quando o docente e o discente estão separados por distância e meios tecnológicos são utilizados para facilitar a comunicação e a construção do conhecimento.

- Perry (1995): estabelecimento de uma comunicação em via dupla quando discentes e docentes não se encontram juntos na mesma sala, mas se utilizam de meios que possibilitem a comunicação, tais 
como: correspondência postal e eletrônica, videodisco controlado por computador, "modem", telefone, fax ou telex, rádio, televisão apoiada em meios abertos de dupla comunicação, entre outros.

- Aretio (1998): sistema tecnológico de comunicação bidirecional que pode ser massivo e substituir a interação pessoal de docente e discente, na sala de aula presencial de ensino, pela ação sistemática e conjunta de diversos recursos didáticos, contando ainda com apoio de uma tutoria, bem como de uma organização, proporcionando uma aprendizagem independente e flexível.

- Moore e Kearsley (2007): aprendizagem planejada que se efetiva normalmente em lugar diferente do típico e se utiliza de técnicas especiais de criação do curso e dos processos de ensino e aprendizagem, as quais são mediadas por tecnologias partindo de disposições organizacionais e condições administrativas especiais.

- Moran (2011, p. 1): "é ensino-aprendizagem em que professores e alunos não estão normalmente juntos, fisicamente, mas podem estar conectados, interligados por tecnologias, principalmente as telemáticas, como a Internet. Mas também podem ser utilizados o correio, o rádio, a televisão, o vídeo, o CD-ROM, o telefone, o fax e tecnologias semelhantes".

- $\operatorname{ABED}(2011$, p. 1): "modalidade de educação em que as atividades de ensino-aprendizagem são desenvolvidas majoritariamente (e em bom número de casos exclusivamente) sem que alunos $e$ professores estejam presentes no mesmo lugar à mesma hora".

A partir do pensamento dos teóricos aqui referenciados, observa-se que em 1967 a EAD era entendida como autoestudo estabelecido a partir de uma 'instrução' mediada por recursos didáticos e acompanhamento de docentes que se utilizavam, para tanto, de meios de comunicação. Já em 1973, a ênfase no papel do aluno que seria responsável por uma autoaprendizagem acompanhada por docentes a partir de meios de comunicação sofre algumas alterações, passando a ser vista como uma maneira 'industrializada' (método racional de partilhar atitudes, habilidades e conhecimentos) de ensinar e aprender, por intermédio do uso extensivo de meios de comunicação. Neste caso, alunos e professores já veem os meios de comunicação como um 
ferramental para se ensinar e aprender (ênfase tanto no ensino, quanto na aprendizagem) conteúdos, pensados a partir de uma concepção mais ampla, incluindo explicitamente aos fatos e conceitos, as habilidades, os procedimentos e as atitudes. Aqui, já se reconhece a EAD como forma de ampliar o acesso dos estudantes à educação.

Prosseguindo, em 1985, se reconhecia também a aplicabilidade da EAD em diferentes níveis de ensino, para além do ensino profissionalizante, permeando vários níveis e modalidades também da educação formal, para a qual, de uma forma parecida com a presencial, se verifica a importância de atividades simultâneas e do acompanhamento próximo e constante do tutor. Ideia esta que prossegue em 1989, quando se retoma a questão da presença dos estudantes, deixando implícita uma ideia de simultaneidade, mas já reconhecendo que este processo poderia ser mediado por meios mecânicos, impressos, eletrônicos etc.

Em 1991, a EAD já é amplamente reconhecida como uma forma de estudo a partir de diferentes ambientes, deixando implícita a ideia de não simultaneidade. Já em 1993, se propõem de forma um pouco mais explícita a quebra da barreira espaço-tempo a partir desta modalidade de educação.

No ano de 1994, este pensamento é reafirmado, ao se propor um definição em que a tecnologia aparece como ferramental capaz de facilitar a construção do conhecimento.

Em 1995, a simultaneidade é total e explicitamente rompida quando se defende que os alunos podem não se encontrarem juntos na mesma sala, mas se utilizar de meios que possibilitem a comunicação para concretizar o processo de ensino-aprendizagem, entendido como uma via de mão-dupla (se utilizando de meios de comunicação como o computador, que dentre outros possibilitavam a concretização da ideia).

Prosseguindo, no ano de 1998, a EAD continuou sendo entendida como uma sistematização tecnológica de comunicação massiva bidirecional, capaz de substituir a interação pessoal de docente e discente; neste momento, já aparecem explícitas ainda as ideias de independência e flexibilidade em relação ao processo de aprendizagem.

Dando um salto, em 2007, além das questões pontuadas, passou-se a admitir também as condições peculiares da EAD que se refere não apenas ao 
processo de ensino-aprendizagem, mas também em relação às suas condições administrativas.

Em 2011, percebemos que as tecnologias são utilizadas, sem a preocupação com o tempo e espaço para interligar e conectar professores e alunos, aqui já deixando implícita a multidirecionalidade (não apenas a bidirecionalidade entendida em outros momentos da história), sendo complementado pela ideia de quebra majoritária da presencialidade e da simultaneidade.

Observa-se, portanto, que há um significativo aporte teórico com inúmeras definições e conceituações de EAD que foram sendo construídas ao longo do tempo e, apesar de algumas divergências pontuais, é possívelidentificar um conjunto relativamente homogêneo de características, o qual permite conceituá-la e atribuir-lhe uma dimensão prática adaptada à atualidade e às demandas por universalização de processos de ensino e de aprendizagem. Assim, em busca de uma definição consensual e abrangente, podemos entendê-la, com base na definição proposta pelo Decreto n. 5622 (BRASIL, 2005), como uma:

[...] modalidade educacional na qual a mediação didáticopedagógica nos processos de ensino e aprendizagem ocorre com a utilização de meios e tecnologias de informação e comunicação, com estudantes e professores desenvolvendo atividades educativas em lugares ou tempos diversos.

São características da EAD (HAWDRIGDE, 1983; HOLMBERG, 1985; ARMENGOL, 1987; KEEGAN, 1991; SCRIVEN, 1991; NUNES, 2010):

- Enfoques educativos majoritariamente andragógicos, apesar de se reconhecer que a EAD pode "prover um programa educativo completo para ambos, crianças e adultos" (KEEGAN, 1991, p. 6). Em todos os casos, é imprescindível que ofereça apoio logístico e institucional, bem como meios permanentes de Motivação individual e estímulo social.

- Cursos mediados por orientadores de aprendizagem preparados para estimular os discentes e a valorizar o processo de aprendizagem, tanto em relação ao tema estudado, quanto no que se refere aos conteúdos, os quais precisam partir da experiência de 
vida e cultura dos discentes e levar em conta aspectos importantes da cultura geral e local, bem como avaliado e verificado se os objetivos estão realmente sendo atingidos.

- Alunos relativamente dispersos pela posição geográfica (separação física), separados temporalmente, com condições culturais, sociais, econômicas e habilidades individuais distintas etc.

- Projetos autoinstrucionais: utiliza-se de materiais elaborados para estudo autônomo, contendo objetivos explícitos, atividades, interatividades, autoavaliações, textos complementares e inúmeras fontes de referências para pesquisas, os quais buscam ampliar as possibilidades de escolha dos discentes, por meio do oferecimento de visões alternativas em relação ao mesmo problema, bem como materiais complementares que auxiliem na formação de um pensamento analítico e crítico.

- Estudo individualizado e desenvolvimento de mecanismos facilitadores de aprendizagem que possibilitem ao discente "aprender a aprender", ou seja, mesmo sendo preparados para grupos, há que se considerar um aspecto relevante: o estudante é um indivíduo com características próprias, que devem ser consideradas e respeitadas ao se propor projetos de ensino e aprendizagem.

- Comunicações organizadas de forma multidirecional que fomentem o desenvolvimento das capacidades de pesquisar, desenvolver e aplicar métodos e técnicas novos de comunicação de dupla ou múltiplas vias.

- Cursos pré-produzidos utiliza-se de multimídias: uso predominante de textos combinados com outros meios e recursos, como periódicos e revistas, obras adicionais, rádio e televisão educativos, filmes, microcomputadores, videotextos, videodiscos, telefone, satélite, equipamentos portáteis etc.

- Comunicações massivas: planejadas e efetivadas para um grande número de estudantes.

- Propostas com avaliações precisas e atualizações frequentes. 
- Formas mediadoras de diálogo direcionado.

- Crescente utilização de novas TIC's: informação não é educação, contudo, a construção do conhecimento se inicia na informação. Assim, tais meios são entendidos como ferramentas, as quais precisam ser adequadamente utilizadas para se alcançar objetivos de ensino e aprendizagem.

- Tendência a adotar estruturas curriculares flexíveis, organizadas em módulos e créditos, cujas estruturas permitam adaptação facilitadaàs possibilidades e aspirações individuais dos discentes, sem detrimento da qualidade acadêmica e do material instrucional.

- Custos decrescentes por alunos, depois de elevados investimentos iniciais: combinando, para tanto, uma administração eficiente com uma população estudantil numerosa.

\section{2 - Evolução da EAD no Brasil}

No Brasil, assim como no resto do mundo, a evolução histórica da oferta de EAD foi marcada pelo surgimento e disseminação dos meios de comunicação. Passamos por uma etapa do ensino por correspondência, pela transmissão radiofônica e, depois, televisiva; utilizamos a informática até os atuais processos de utilização conjugada de meios como a internet, a telemática e a multimídia (SARAIVA, 1996; ROSENBERG, 2006; MOORE; KEARSLEY, 2007).

Para entender essa evolução, se faz necessário conhecer as tecnologias que despontaram em cada geração de EAD, bem como a importância de uma delas para a formação do contexto atual:

Figura 2Tecnologias predominantes nas Gerações da EAD no Brasil.

\begin{tabular}{|c|c|c|}
\hline GERAÇÃO & TECNOLOGIA & CARACTERISTICA \\
\hline $\begin{array}{l}\text { Primeira Geração } \\
\qquad 1850 \text { a } 1960\end{array}$ & $\begin{array}{l}\text { Começa via papel impresso e anos mais } \\
\text { tarde ganha a participaçăo do rádio e da } \\
\text { televisão. }\end{array}$ & $\begin{array}{l}\text { uma tecnologia } \\
\text { predominante }\end{array}$ \\
\hline $\begin{array}{l}\text { Segunda Geração } \\
\qquad 1960 \text { a } 1985\end{array}$ & $\begin{array}{l}\text { Os meios são fitas de áudio, televisão, } \\
\text { fitas de vídeo, fax e papel impresso. }\end{array}$ & $\begin{array}{l}\text { múltiplas tecnologias sem } \\
\text { computadores. }\end{array}$ \\
\hline $\begin{array}{c}\text { Terceira Geração } \\
1985 \text { a } 1995\end{array}$ & $\begin{array}{l}\text { Correio eletrônico, papel impresso, } \\
\text { sessőes de chat, mediante uso } \\
\text { de computadores, Internet, CD, } \\
\text { videoconferência e fax. }\end{array}$ & $\begin{array}{l}\text { múltiplas tecnologias } \\
\text { incluindo os computadores } \\
\text { e as redes de computadores }\end{array}$ \\
\hline $\begin{array}{l}\text { Quarta Geração } \\
1995 \text { a } 2005\end{array}$ & $\begin{array}{l}\text { Correio eletrônico, chat, computador, } \\
\text { Internet, transmissões em banda } \\
\text { larga, interação por vídeo e ao vivo, } \\
\text { videoconferência, fax, papel impresso. }\end{array}$ & $\begin{array}{l}\text { múltiplas tecnologias } \\
\text { incluindo o começo das } \\
\text { tecnologias computacionais } \\
\text { de banda larga e } \\
\text { aprendizagem flexivel }\end{array}$ \\
\hline $\begin{array}{c}\text { Quinta Geração } \\
2006 \text { até atualidade }\end{array}$ & $\begin{array}{l}\text { Reunião de tudo o que a quarta geração } \\
\text { oferece mais a comunicação via } \\
\text { computadores com sistema de respostas } \\
\text { automatizadas, além de acesso via portal } \\
\text { a processos institucionais. }\end{array}$ & $\begin{array}{l}\text { múltiplas tecnologias } \\
\text { computacionais de } \\
\text { banda larga (fórum, chat, } \\
\text { teleconferências, vídeo } \\
\text { aulas, etc.) e aprendizagem } \\
\text { flexivel e inteligente. }\end{array}$ \\
\hline
\end{tabular}


Fonte: NOVA, F. Gerações de EAD marcadas por diferentes tecnologias. E-learning Brasil (2004). Disponível em: <http://portal.webaula.com.br/noticia.aspx?sm=noticias\&codnoticia=15>. Acesso em: 1 dez. 2010.

O diferencial se concentra, portanto, na utilização de ferramentas síncronas e assíncronas para comunicação, interação e aprendizagem nos AVAs.

Figura 3Gerações da EAD.

PRIMEIRA GERAÇÃO

Ocorreram os estudos por correspondência em casa de forma independente e proporcionam o fundamento para a individualidade do estudo na EaD

SEGUNDA GERAÇÃO

Ocorreu a transmissão por rádio e televisão, teve pouca ou nenhuma interação entre professores e alunos, a única alternativa eram correspondências, porém o marco foi agregar as mídias orais e visuais à apresentação de informação aos alunos a distância.

TERCEIRA GERAÇÃO

Surgiram as universidades abertas, experiência norte-americana que agregava áudio e vídeo e correspondência, além disto, vieram as orientações face a face, por meio de equipes de curso e um método prático para a criação e veiculação de uma abordagem sistêmica para os projetos em EaD.

QUARTA GERAÇÃO

Iniciou o uso da teleconferência por áudio, vídeo e computador, proporcionando a primeira interação em tempo real de alunos e instrutores a distância. O Método era apreciado especialmente para treinamento corporativo.

QUINTA GERAÇÃO

Diferenciada pelo uso de espaços online com base Internet, o que tem resultado em enorme interesse e atividade em escala mundial pela educação a distância, com métodos construtivistas de aprendizado em colaboração, e na convergência entre texto, áudio e vídeo em uma mesma plataforma de comunicação.

Fonte: MOORE, M.; KEARSLEY, G. Educação a distância: uma visão integrada. São Paulo: Cengage Learning, 2007, p. 26.

Salienta-se que a EAD, apesar de ter sofrido um preconceito histórico, atualmente não pode e não tem sido mais vista como uma panaceia para todos os males da educação brasileira (BRASIL, 2006). Verifica-se, portanto, um esforço dos pensadores e pesquisadores da educação, bem como dos educadores em demonstrar que os problemas da educação brasileira não se concentram somente no interior do sistema educacional, mas, sobretudo, na situação de polaridade e desigualdade social.

Nesse contexto, a EAD, assim como outras modalidades de educação, pode contribuir de forma significativa para o desenvolvimento educacional do nosso país (LUCKESI, 1989). 
Além disso, o desenvolvimento das TIC's, pode encontrar na EAD uma alternativa viável e capaz de proporcionar incontáveis possibilidades de expansão das ofertas educacionais em processo continuado, especialmente pelo fato de a EAD ser flexível e se utilizar de mediações tecnológicas que articulam o centro de formação, as inter-relações de circunstâncias e a adequação às mediações utilizadas para se aproximar dos contextos reais de inserção profissional (SABA, 2003; CORRÊA et al., 2006). Destacam-se ainda as seguintes possibilidades de atuação da EAD(RUMBLE, OLIVEIRA, 1992; MARTINS, 2009a; LÉVY, 2009, MORAN, 2009a, NUNES, 2010):

- Democratização do conhecimento: passo fundamental nessa direção é dado pela educação formal a distância quando consegue garantir mínimas condições de acesso à cultura ao maior número possível de cidadãos, especialmente no que tange à universalização do ensino básico (meta a ser atingida- BRASIL, CF. Art. 214). Contudo, a introdução cada vez maior de elementos tecnológicos e científicos, nos mais variados campos da ação humana, tem exigido demandas em velocidade que o ensino formal não consegue acompanhar, requisitando também ações que ultrapassam as fronteiras da educação formal (educação não-formal ou informal)e que sejam capazes de contribuírem por meio de procedimentos adequados e sistematizadospara a formação integral, para o fortalecimento de uma mentalidade autônoma, criativa e crítica, bem como para gerar processos continuados de acesso ao conhecimento.

- Educação para a cidadania: "um conjunto significativo de ações educativas podem ser levadas a termo com a EAD, transformando processos cívicos obrigatórios por lei em processos realmente participativos e conscientes. Temas fundamentais da existência contemporânea de nossa sociedade podem, e devem, ser tratados de forma sistemática através de cursos, ou meios educativos sistemáticos, capazes de elevar o nível de participação responsável da sociedade no processo de construção da nacionalidade. A integração das organizações da sociedade civil com os movimentos populares certamente produzirá frutos fundamentais, apoiados por procedimentos educativos a distância" (NUNES, 2010, p. 1). 
- Formação e capacitação profissional: considerando que este tipo de atuação foi o caminho que a EAD iniciou a trilhar para se desenvolver, reconhece-se sua potencialidade tanto em nível da formação profissional básica inicial e continuada, como de formação corporativa (pública e privada), universitária e especializada de trabalhadores. Observa-se que, para qualificação profissional, há atualmente uma variedade significativa de cursos: cursos individuais prontos, cursos realizados para pequenos grupos, cursos corporativos e in company, cursos para grandes grupos, parcerias e consórcios em EAD etc. (MORAN, 2009b).

- Capacitação e atualização de professores: evidenciou-se com a aprovação da LDB, que aprovou a EAD como modalidade para o sistema de ensino e veio efetivamente em um momento em que se tinha urgência em garantir de forma permanente a expansão e consolidação da formação continuada, possibilitando uma melhoria significativa da prática docente para a formação do cidadão competente (MARTINS, 2009b). Além disso, a EAD permite que "os professores aprendem ao mesmo tempo que os estudantes e atualizam continuamente tanto seus saberes disciplinares quanto suas competências pedagógicas (a formação contínua dos docentes é uma das aplicações mais evidentes dos métodos do aprendizado e à distância)"(LÉVY, 2009, p. 9).

Nesse contexto, verifica-se ainda, no Brasil, um esforço histórico em superar alguns problemas que foram responsáveis por retardar o progresso da modalidadeEAD (NUNES, 2010):

- Inexistência ou incidência de poucos critérios de avaliação dos programas projetos.

- Estruturação de projetos piloto sem prepará-lo adequadamente para seu seguimento.

- Existência reduzida de uma memória sistematizada dos programas desenvolvidos e das avaliações realizadas (quando essas existiam).

- Inexistência de estruturas institucionalizadas para a administração, acompanhamento e auditoria dos projetos. 
- Falta de continuidade de programas sem prestação de contas às entidades financiadoras, aos governos e à sociedade.

- Programas pouco vinculados ou mesmo desvinculados das necessidades reais e das necessidades locais e/ou do país.

- Pouca, inadequada ou inexistente divulgação dos projetos.

- Testagem da metodologia como único fim para a organização de projetos pilotos.

- Existência de uma visão administrativa e política que desconhece os potenciais e as exigências da EAD.

- Administração de projetos por pessoal sem a necessária qualificação técnica e profissional.

Assim, devido à sua complexidade, as instituições de ensino que trabalham com a modalidade de EAD precisam, cada vez mais, manter uma grande competência em P\&D, detectar sinais do ambiente sobre potencial de mudança, selecionar oportunidades de acordo com seu contexto e estratégia global, implementar ideias, executar projetos inovadores e aprender constantemente com erros para reinventar seus processos (TIDD, BESSANT; PAVITT, 2008).

Observa-se ainda que as rotinas eficazes de gestão e efetivação das propostas e objetivos didático-pedagógicos dos projetos de EAD não têm sido facilmente obtidos. Assim, é preciso que os referidos projetos sejam constantemente reavaliados de forma integrada, por meio do desenvolvimento de habilidades nas mais distintas áreas, como reconhecimento de sinais pedagógicos, institucionais, tecnológicos e econômicos, alinhamento entre estratégia institucional e mudança proposta, aquisição de conhecimentos, capacidade de geração de tecnologia interna, escolha da resposta mais adequada diante dos estímulos ambientais, execução dos projetos (desde a ideia inicial até os procedimentos finais, como $\circ$ material didático), implementação das mudanças e, até mesmo, desenvolvimento da IES que atua no contexto da $E A D$, já que as referidas instituições vêm de uma prática de ensino cultural e tradicionalmente presencial. 


\section{3 - Tendências e Perspectivas}

Uma reflexão sobre as tendências e perspectivas pode ser iniciada pelo reconhecimento das quatro recomendações sobre a EAD para o contexto nacional (ABED, 1996): explicar e divulgar a EAD, incentivar a organização de formação de recursos humanos para a EAD, buscar e adequar a legislação educacional brasileira às características da EAD e enfatizar a importância da EAD na qualificação do trabalhador.

Partindo dessas ideias, podem-se entender os rumos que a EAD vem tomando desde 1996, quando foi oficializada pela LDB. Destacam-se, nesse contexto, quatro tendências e possibilidades trazidas pela EAD aos âmbitos metodológico, institucional, discente e docente (CAVALCANTI, 2011):

- Metodológico: pode promover uma aprendizagem colaborativa e social.

- Institucional: a oferta de cursos nesta modalidade está e continuará evoluindo rapidamente.

- Discente: é possível que ainda se verifique resistência cultural no que se refere à EAD; entretanto com indícios de mudanças neste tipo de ideologia.

- Docente: as atividades, funções, expectativas e papéis desse profissional passam por constantes mudanças com a expansão da EAD.

É inquestionável que a utilização das TIC's na EAD tem conquistado uma posição de destaque, especialmente, ao propiciar que modelos inovadores de ensino-aprendizagem possam ser idealizados, planejados, executados e utilizados.

Atualmente, como relexão sobre as tendências e perspectivas da EAD, têm sido aferido os seguintes questionamentos à EAD Brasileira: "o Brasil é um país inovador em EAD ou apenas um seguidor? Quem, indivíduos ou instituições, tem demonstrado ser um verdadeiro inovador? A cultura brasileira encoraja ou inibe o espírito inovador ou cria barreiras ao seu funcionamento? Qual seria a infraestrutura ideal de condições para fomentar a inovação na aprendizagem na modalidade EAD dentro da realidade brasileira?" (LITTO, 2009). Respondê-los ainda é um desafio em construção, o qual se faz 
indispensável para entendermos com clareza a realidade em que se encontra o efetivo contexto da EAD no Brasil.

Observa-se, finalmente, que tanto as IES, como as demais corporações, cada vez mais, buscam experimentar, acertar, errar, aprender e conquistar seu espaço no segmento de educação, independente da modalidade para qual é planejada e executada. 


\section{Capítulo 4 - Material Didático}

O material didático é um dos recursos indispensáveis da educação na modalidade de EAD, constituindo-se como um dos principais recursos pedagógicos para o processo de ensino e aprendizagem na mediação professor-aluno (BRASIL, 2007).

Além disso, o Material Didático mediado pelas tecnologias da informação como o telefone, o fax, o correio, o computador e a internet (AVA) tem o potencial de contribuir para o estabelecimento de um vínculo interativo e colaborativo entre o tutor e o(s) estudante(s) entre si, tornando-se indispensável à construção do conhecimento de modo participativo. Nele se ancora uma parte significativa do processo de ensino e aprendizagem na modalidade EAD.

O processo editorial de produção de Material Didático da EAD, em geral, busca inspiração, no que se refere aos aspectos técnicos e burocráticos, no modelo editorial adotado pelas casas publicadoras do país ou no modelo adotado na dramaturgia televisiva e/ou pelos provedores de internet, dependendo da mídia a ser utilizada. Estrutura-se, na maioria das vezes, em vários setores e o planejamento das ações de produção editorial é extremamente importante, uma vez que não se improvisa em cursos EAD. As ações tendem a ser planejadas, previstas e antecipadas. Não se admitem retroatividades nem explicações retóricas. Dado o start da oferta do curso, estabelece-se um continuum, cuja interrupção só causaria agravantes e contratempos. Isso explica a importância de planejar e estruturar os processos editoriais, para responder com eficiência às necessidades percebidas.

No caso específico do material em texto, por exemplo, verificam-se etapas como: o técnico pedagógico, responsável pela concepção pedagógica, didática e pela elaboração efetiva dos conteúdos; o Editorial, responsável pela contratação, seleção e aprovação dos materiais a serem impressos; o de Editoração, responsável pela preparação e revisão dos textos; o de arte, responsável pelo layout e interface geral, pela diagramação e arte-finalização; o de logística, responsável pela impressão do material pelo controle de entrada e saída de material quando impresso ou disponível em mídias como o CDROM ou DVD-ROM, de reedições etc.; o Setor Jurídico, que se responsabiliza 
pelos contratos de autorias e questões relacionadas a direitos morais e patrimoniais. Outros materiais multimídia ainda teriam setores técnicos que envolvem profissionais como: diretores de arte, programadores, criadores, designers de imagens etc., todos com funções pré-determinadas, as quais têm fomentado na IES a busca por conhecimentos e técnicas utilizadas em meios de comunicação como o rádio, a televisão, a internet etc.

\section{1 - Material Didático: Legislação}

Dentre outros recursos e técnicas utilizados nos processos de ensino e aprendizagem, o material didático tem sido reconhecido como um instrumento de aprendizagem flexível, que precisa procurar responder ao mais próximo possível do ideal de formação pessoal e profissional dos discentes e às demandas de mercado da cidade, da região e do país.

Um material didático de qualidade guarda, portanto, uma relação direta com o projeto pedagógico do curso. Por essa razão, não pode ser elaborado à revelia do objetivo geral do curso, do perfil do egresso, do ementário, da matriz programática e sem uma compreensão do todo das disciplinas. Assim, o recurso em questão deriva do projeto pedagógico e é parte integrante do processo de ensino e aprendizagem EAD. É ele que estimula, motiva e instiga o aluno à autonomia em relação ao seu estudo, bem como o faz avançar em sua busca pelo conhecimento de forma colaborativa e cooperativa. Serve de guia ao tutor e pode afetar, negativa ou positivamente, o desempenho cognitivo e a aquisição de habilidades do aluno e, consequentemente, representa mais um fator para determinar o alto ou o baixo nível de qualidade do curso.

Sob este contexto, o Projeto Pedagógico do curso pode ser entendido como um documento no qual todos os recursos, mídias e estratégias didáticas precisam estar planejados e estruturados. Destaca-se ainda que o referido projeto "está inserido em um cenário marcado pela diversidade" (GADOTTI, 1998, p. 16). Ele é realizado de acordo com os pressupostos, legislação e regulamentação da Educação Superior no Brasil, cujas diretrizes permeiam todo o processo de elaboração dos materiais didáticos.

Além disso, o material didático elaborado para cursos superiores na modalidade EAD precisa estar em consonância com os Referenciais de 
qualidade para cursos a distância no nível de Graduação (Pós-graduação e Extensão EAD), nos quais constata-se que:

[...] a base principal das práticas de qualidade nos projetos e processos de Educação Superior é garantir continuamente melhorias na criação, aperfeiçoamento, divulgação de conhecimentos culturais, científicos, tecnológicos e profissionais que contribuam para superar os problemas regionais, nacionais e internacionais e para o desenvolvimento sustentável dos seres humanos, sem exclusões, nas comunidades e ambientes em que vivem (BRASIL, 2007).

Com o objetivo de auxiliar a aprendizagem, assegurando ganhos pedagógicos e atingindo objetivos, habilidades, competências e atitudes propostos para a disciplina, os materiais didáticos precisam ainda estar adequados no que se refere à (SINAES, 2010):

- abrangência: explanação, reflexão e diálogo proposto sobre as diferentes concepções teórico-científicas que justificam, ratificam e ampliam o ponto de vista, bem como a abordagem do autor em relação ao conteúdo;

- densidade: explicitação substanciosa e rica dos conteúdos e referências apresentadas, bem como apresentaçãocoesa, precisa e sucinta de dados, informações e conhecimentos cientificamente aceitos e comprovados;

- profundidade: proposição de um nível de domínio e conhecimento da etiologia e das abordagens epistemológicas apresentadas em conformidade ao perfil esperado do aluno na fase em que se encontra.

Consequentemente, um material que reúna tais condições não somente atenderá aos indicadores de qualidade preconizados nos documentos regulatórios da Educação Superior, como também e principalmente se reverterá em ganhos pedagógicos para o discente.

\section{2 - Processos de Produção}

À luz do projeto pedagógico elaborado pela comunidade acadêmica para o curso, tem-se a gênese de seu processo na orientação pedagógica ao 
docente/autor, a qual pode ocorrer antes e durante todo o processo de elaboração e editoração de um material didático. O professor indicado pela coordenação do curso pode agendar reuniões presenciais e/ou por meio da utilização de recursos de telecomunicações e elaboram juntos o Plano de Ensino ou guia, em que são determinadas quais mídias serão utilizadas e todas as orientações e informações necessárias para o processo ensinoaprendizagem de determinada disciplina.

Nota-se que além dos objetivos (factuais, conceituais, procedimentais e atitudinais) propostos no projeto pedagógico e ratificados no Plano de ensino da disciplina, os materiais didáticos precisam ainda "identificar os objetivos referentes a competências cognitivas, habilidades e atitudes" (BRASIL, 2007). Tais objetivos podem ser traçados diante de uma nova leitura da taxonomia dos objetivos proposta por Benjamin Bloom (1950), na qual a lista de processos cognitivos é organizada do mais simples (ter uma informação) ao mais complexo (julgamento de valor), diferenciando o conteúdo do raciocínio ("saber o que") dos procedimentos para resolver problemas ("saber como"). Desse modo, subdivide-se a aquisição do conhecimento em quatro categorias (ANDERSON; KRATHWOHL, 2001):

- Conhecimento factual (informações básicas): consiste nos conhecimentos de detalhes dos elementos isolados e específicos de uma informação e no conhecimento de terminologias. Exemplos: alfabeto, símbolos matemáticos, nome de representantes de determinada teoria, termos de vocabulários etc.

- Conhecimento conceitual (relações entre as partes de uma estrutura que funciona em conjunto): refere-se ao conhecimento de teorias, modelos, estruturas, princípios, generalizações, classificações, categorias e sistemas de informação. Exemplos: princípios da democracia, diferentes tipos de argumentos, modelos de DNA, teoria da evolução etc.

- Conhecimento procedimental (como fazer): trata-se do conhecimento de técnicas, heurísticas, métodos, algoritmos, habilidades específicas sobre um assunto, bem como critérios para determinar quando usar um procedimento. Exemplos: análises 
estatísticas, crítica literária, resolução de equações numéricas, mistura de tintas para realizar uma pintura, saque no vôlei etc.

- Conhecimento metacognitivo (refletir e raciocinar de modo específico ou geral sobre o que se sabe): remete-nos ao autoconhecimento, ao conhecimento sobre tarefas cognitivas (contextual e condicional), ao conhecimento estratégico e ao conhecimento dos processos cognitivos e das informações sobre como manipulá-los de forma eficaz.

Segundo essa concepção, a aprendizagem deve enfatizar, dentre outros aspectos que vão além do puro raciocínio (como propôs Bloom em 1956), as crenças e os sentimentos de alunos e professores, a construção dos conhecimentos e os processos cognitivos necessários para a resolução de problemas (ANDERSON; KRATHWOHL, 2001).

Finalmente, tendo essa teoria como referência, enfatiza-se que os objetivos representarão o cerne de todo o conteúdo disponibilizado e da avaliação proposta.

Precisa-se ainda assegurar nesses materiais (MCKNIGHT, RICHARDSON, DILLON, 1989; NIELSEN, 1990; VINCE, s/d.; BRASIL, 2007):

- Legibilidade pedagógica: garantida pela estrutura pedagógica previamente sugerida pelo autor, pela validação da sincronia do material didático elaborado com o Projeto Pedagógico do curso e com o Plano de Ensino da Disciplina, bem como com o tratamento pedagógico, em que se procura aplicar uma linguagem proximal e autoinstrucional (ZPD: Vygostky - texto que seja pensado e elaborado com a intenção de mediar a aprendizagem do aluno). São verificados os textos que poderiam ser transformados em tabelas, esquemas, mapas mentais, bem como se a linguagem está adequada ao público-alvo, a quantidade de texto e os parágrafos estão adequados para não causar sobrecarga conceitual nos alunos, se são contemplados os quatro tipos de conteúdos (factuais, conceituais, procedimentais e atitudinais), se há exemplos, contraexemplos para contextualização dos conteúdos etc. (CENTRO REFERENCIAL DE EDUCAÇÃO, 2011). 
- Legibilidade técnica e tipográfica: ilustração, padronização e normalização do texto, projeto gráfico etc.

- Legibilidade científica: garantida na escolha de um profissional habilitado e qualificado (com titulação igual ou maior que a do autor, na mesma área) para escrever o material e para a validação entre pares, no modelo blindreview. Em geral, essa avaliação é oficializada por meio de questionários compostos por questões abertas e fechadas e um parecer final para inserção de sugestões pelo profissional que realiza a avaliação (vista neste ensejo como uma forma de contribuição ao trabalho do autor).

- Retroalimentação externa da concepção e produção de material didático: validação em diferentes momentos pelo tutor, pelos alunos e por outros agentes.

- Retroalimentação interna da concepção e produção de material didático: os colaboradores precisam ter um espaço aberto (comunidade de prática, sala virtual específica com este objetivo, ou lista permanente de e-mails etc.) para expor seus conhecimentos e dar opiniões e sugestões pessoais sobre o processo que executam (de forma anônima ou não), bem como acessar e ler as sugestões dos demais colegas. Propõe-se, mesmo que de forma ainda rudimentar, gerenciar o conhecimento dos profissionais envolvidos, transformando os conhecimentos pessoais em conhecimentos institucionais, à disposição de todos.

$\mathrm{Na}$ IES na qual a pesquisa foi realizada, como exemplicifacação prática, verifica-se a elaboração convencional de material didático em mídias como: material em texto, videoaulas, vídeo conferências, web conferências, Sistema Gerenciador de Aprendizagem, cuja descrição foi elaborada seguindo pressupostos da legislação daEducação Superior, bem como os Referenciais de qualidade para Educação Superior a distância (BRASIL, 2007) e inspirada em algumas práticas institucionais.

De forma geral, segue detalhamento utilizado em algumas mídias utilizadas pelas IES brasileiras:

- Material texto (impresso ou para leitura em tela): 
$\checkmark$ Elaboração de design gráfico, modelagem e estilo editorialpedagógico.

$\checkmark$ Orientação síncrona e/ou assíncrona ao docente/autor.

$\checkmark$ Elaboração pelo autor do texto original.

$\checkmark$ Revisão do texto pelo autor sempre após a finalização de cada uma das etapas.

$\checkmark$ Validação do texto, em geral, pelo modelo blindreview.

$\checkmark$ Validação do texto pela coordenação pedagógica do curso no intuito de assegurar a legibilidade pedagógica.

$\checkmark$ Preparação do texto e mediação pedagógica.

$\checkmark$ Criação, captação e tratamento de imagens.

$\checkmark$ Revisão ortográfica e gramatical (em duas ou três etapas).

$\checkmark$ Diagramação e emendas.

$\checkmark$ Validação do texto pelos tutores que acompanharão os alunos na sala de aula.

$\checkmark$ Validação da aplicabilidade do texto ao público-alvo.

$\checkmark$ Arte-finalização.

$\checkmark$ Reprodução gráfica, gravação em mídias ou disponibilização na web.

- Videoaulas com ou sem animação (vídeos de apresentação de informações e orientações para o estudo da disciplina ou elaborados para a construção dos conteúdos):

$\checkmark$ Elaboração de design gráfico, incluindo as imagens e a máscarasugestão do roteiro.

$\checkmark$ Orientação síncrona e/ou assíncrona ao docente/autor.

$\checkmark$ Elaboração do roteiro.

$\checkmark$ Revisão do autor sempre após a finalização de cada uma das etapas.

$\checkmark$ Validação do roteiro, em geral, pelo modeloblindreview.

$\checkmark$ Validação do roteiro pela coordenação pedagógicado curso para assegurar a legibilidade pedagógica.

$\checkmark$ Revisão pedagógica do roteiro / Preparação do material.

$\checkmark$ Produção do roteiro.

$\checkmark$ Envio do roteiro. 
$\checkmark$ Produção e tratamento de imagens estáticas.

$\checkmark$ Gravação.

$\checkmark$ Gravação de áudio.

$\checkmark$ Tratamento de áudio.

$\checkmark$ Edição.

$\checkmark$ Animação e finalização.

$\checkmark$ Revisão do diretor.

$\checkmark$ Validação do texto pelos tutores que acompanharão os alunos na sala de aula.

$\checkmark$ Validação da aplicabilidade do texto ao público-alvo.

$\checkmark$ Finalização: arte-finalização com adequação ou inserção de ajustes que se fizerem necessários.

$\checkmark$ Publicação no ambiente virtual.

$\checkmark$ Eventuais conversões que se fizerem necessárias.

$\checkmark$ Autoração do DVD.

$\checkmark$ Duplicação das mídias e/ou disponibilização na web.

$\checkmark$ Publicação na web (Sistema Gerenciador de Aprendizagem).

- Webconferência:

$\checkmark$ Agendamento

$\checkmark$ Elaboração do roteiro-proposta para webconferência.

$\checkmark$ Confirmação do agendamento e da webconferência.

$\checkmark$ Validação do texto pela coordenação pedagógica do curso com o intuito de assegurar a legibilidade pedagógica.

$\checkmark$ Web conferência e gravação.

- Sistema Gerenciador de Aprendizagem - Moodle:

$\checkmark$ Informações para a criação do ambiente.

$\checkmark$ Criação dos ambientes.

$\checkmark$ Inserção de materiais.

$\checkmark$ Padronização e formatação dos documentos.

$\checkmark$ Validação do texto pelos tutores que acompanharão os alunos na sala de aula.

$\checkmark$ Validação da aplicabilidade do texto ao público-alvo.

$\checkmark$ Aprovação final da disciplina no Sistema Gerenciador de Aprendizagem (checklist). 
Com base nessas considerações, as IES de forma geral, procuram preservar suas peculiaridades e objetivos, por meio de núcleos próprios para gerenciamento dos projetos de EAD, seguem na tentativa constante de responder às condições necessárias para a elaboração e produção de um material didático de qualidade.

\section{3 - Acessibilidade no Material Didático para EAD}

Atualmente, a EAD tem se mostrado mais aprazível e receptiva para as pessoas com algum tipo de necessidade especial, uma vez que tem procurado favorecer e potencializar a utilização de tecnologias assistivas, a formação continuada e o processo de educação inclusiva. Entretanto, como tratado na introdução deste trabalho, esta questão ainda precisa ser melhorada na tentativa de atender a totalidade dos alunos que frequentam ou querem frequentar a Educação Superior.

Reconhece-se, nesse contexto, que os materiais didáticos apresentados em AVAs, junto a outros elementos, têm potencial para proporcionar novas oportunidades e eliminar possíveis barreiras, especialmente no que se refere aos discentes que frequentam a Educação Superior (YODER et al., 2007). Cada um desses discentes, independente de suas características, habilidades ou necessidades especiais, pode encontrar uma ou mais barreiras de acesso aos materiais didáticos utilizados na EAD, uma vez que cada pessoa apresenta peculiaridades, particularidades e preferências específicas em relação às situações de acesso, as quais, em geral, são apresentadas em única opção (W3C, 2011).

Nesse contexto, uma maneira viável e adequada de permitir o acesso aos materiais didáticos de um curso superior oferecido na EAD é a aplicação dos princípios do DU para a Aprendizagem que pode permitir que esses recursos se mostrem mais sensíveis às preferências e habilidades individuais na apresentação dos conteúdos e dispensam adaptações ou design especial para as pessoas com necessidades especiais. O DU para a Aprendizagem ainda considera e enfatiza as habilidades e questões históricas, sociais, políticas, econômicas, antropológicas, tecnológicas, ergonômicas e de usabilidade, procurando encontrar respostas para as necessidades $\mathrm{e}$ preferências de todos: pessoas de diferentes idades, habilidades cognitivas, 
físicas e sensoriais (BURGSTAHLER, 2000; HRICKO, 2002; BURGSTAHLER, MOORE, 2009).

Portanto, acessibilidade no material didático significa facilidade de interação ou aproximação (CARRION, 2008). Ela objetiva tornar o acesso desses recursos por meio do uso dos computadores e da internet possível para todos os usuários (SCHNEIDERMANN, 1998; 2002; 2004). Implica, portanto, a habilidade de encontrar, manipular e utilizar a informação de modo compreensível e eficiente, independente das características do usuário, situação ou ferramenta (LESKI, 1998 apud BURGSTAHLER, 2008). Além de envolver sites e aplicativos, nos quais todas as pessoas possam navegar, interagir, perceber e compreender, que possa ser utilizado efetivamente por pessoas com necessidades especiais, que funcionam com tecnologias assistivas e com outras de produção e apresentação de conteúdo (W3C, 2011).

Observamos que, embora o ferramental acessível seja imprescindível, por si só ele não pode resolver todas as barreiras de acessibilidade. É preciso também que os conteúdos sejam adequados e que prevejam a possibilidade de acesso por meio destes recursos (HENRY, 2006).

A ABNT normatiza no Brasil os critérios de acessibilidade na construção de sites e portais da internet, ambientes nos quais os materiais didáticos são disponibilizados. Contudo, essa exigência legal de acessibilidade digital tem ficado restrita aos sites de órgãos governamentais (IPEA, 2011). Além disso, no Brasil, a acessibilidade esbarra em uma conexão lenta, equipamentos e softwares desatualizados, telas pequenas, browser textuais, dentre outras (W3C, 2011).

Destaca-se que cursos de EAD acessíveis precisam superar esses desafios, desde a sua concepção, possibilitar de forma contínua a participação de discentes e docentes com diversidade de impedimentos e habilidades, garantido, de forma especial, que todo o material didático nele disponibilizado respeite a diversidade e esteja acessível a todos os envolvidos.

\section{4 - Dimensões de Sustentabilidade no Material Didático}

O documento Ciência \& Tecnologia para o Desenvolvimento Sustentável, elaborado a pedido do Ministério do Meio Ambiente (MMA), apresenta as seguintes dimensões da sustentabilidade, as quais também 
precisam ser consideradas na elaboração e editoração dos materiais didáticos (BRASIL, 2010):

- Sustentabilidade social: ancorada no princípio da equidade na distribuição de renda e de bens, no princípio da igualdade de direitos à dignidade humana e no princípio de solidariedade dos laços sociais;

- Sustentabilidade ecológica: ancorada no princípio da solidariedade com o planeta e suas riquezas e com a biosfera que o envolve;

- Sustentabilidade econômica: avaliada a partir da sustentabilidade social propiciada pela organização e viabilização da vida material;

- Sustentabilidade espacial: norteada pelo alcance de uma equanimidade nas relações inter-regionais e na distribuição entre o rural/urbano e o urbano;

- Sustentabilidade político-institucional: estar de acordo com a missão, a visão, os objetivos etc. da IES e da comunidade que a constitui representa um pré-requisito para a continuidade de qualquer curso de ação a longo prazo;

- Sustentabilidade cultural: modulada pelo respeito à afirmação do local, do regional e do nacional, no contexto da padronização imposta pela globalização.

Ressalta-se que a incorporação dos princípios do DU para a AprendizagememMateriaisDidáticostrata-se de umapropostaque pode ser sustentávelem todos os âmbitos, com destaque para a sustentabilidadeeconômica, uma vez que, de forma crescente, os softwares e aplicativos têm sido disponibilizados gratuitamente ou a umcustomaisacessível, permitindo a implementaçãode inúmeras propostasdidáticasem grande escala. Contudo, neste caso, é uma equipe multidisciplinar de profissionais, criativa e disposta a superardesafios que conseguirá o desenvolvimento de umprojetodestanaturezaefetivamentesustentável, uma vez que hávárioscaminhos que podem ser trilhados para a implementação de diferentespropostasdidáticas, os quaisvãomuitoalém das ferramentas e possibilidades proporcionadas pelasTICs. 
Ademais, ao se produzir o material didático para seus cursos superiores, sugere-se que os profissionais que compõem a comunidade das IES superem continuamente o paradigma cartesiano, substituindo-o pelo paradigma de sustentabilidade:

Quadro 2 Principais características dos paradigmas cartesiano e sustentável.

\begin{tabular}{|c|c|}
\hline Cartesiano & Sustentável \\
\hline $\begin{array}{l}\text { Reducionista, mecanicista, } \\
\text { tecnocêntrico }\end{array}$ & Orgânico, holístico, participativo \\
\hline Fatos e valores não relacionados & Fatos e valores fortemente relacionados \\
\hline $\begin{array}{l}\text { Preceitos éticos desconectados } \\
\text { das práticas cotidianas }\end{array}$ & Ética integrada ao cotidiano \\
\hline $\begin{array}{l}\text { Separação entre o objetivo e o } \\
\text { subjetivo }\end{array}$ & Interação entre o objetivo e o subjetivo \\
\hline $\begin{array}{l}\text { Seres humanos e ecossistemas } \\
\text { separados, em uma relação de } \\
\text { dominação }\end{array}$ & $\begin{array}{l}\text { Seres humanos inseparáveis dos } \\
\text { ecossistemas, em uma relação de } \\
\text { sinergia }\end{array}$ \\
\hline $\begin{array}{l}\text { Conhecimento compartimentado } \\
\text { e empírico }\end{array}$ & $\begin{array}{l}\text { Conhecimento indivisível, empírico e } \\
\text { intuitivo }\end{array}$ \\
\hline Relação linear de causa e efeito & Relação não-linear de causa e efeito \\
\hline $\begin{array}{l}\text { Natureza entendida como } \\
\text { descontínua, o todo formado } \\
\text { pela soma das partes }\end{array}$ & $\begin{array}{l}\text { Natureza entendida como um conjunto } \\
\text { de sistemas inter-relacionados, o todo } \\
\text { maior que a soma das partes }\end{array}$ \\
\hline $\begin{array}{l}\text { Bem-estar avaliado por relação } \\
\text { de poder (dinheiro, influência, } \\
\text { recursos) }\end{array}$ & $\begin{array}{l}\text { Bem-estar avaliado pela qualidade das } \\
\text { inter-relações entre os sistemas } \\
\text { ambientais e sociais }\end{array}$ \\
\hline $\begin{array}{l}\text { Ênfase na quantidade (renda per } \\
\text { capita) }\end{array}$ & Ênfase na qualidade (qualidade de vida) \\
\hline Análise & Síntese \\
\hline Centralização de poder & Descentralização de poder \\
\hline Especialização & Transdisciplinaridade \\
\hline Ênfase na competição & Ênfase na cooperação \\
\hline $\begin{array}{l}\text { Pouco ou nenhum limite } \\
\text { tecnológico }\end{array}$ & $\begin{array}{l}\text { Limite tecnológico definido pela } \\
\text { sustentabilidade }\end{array}$ \\
\hline
\end{tabular}

Fonte: Adaptado de ALMEIDA, F. O bom negócio da sustentabilidade. Rio de Janeiro: Nova Fronteira, 2002.

Salienta-se que, dentre outros aspectos de igual relevância, a importância do aprimoramento constante dos processos de planejamento, elaboração e difusão do material didático para a garantia das sustentabilidadeseconômica, social, ecológica, espacial, político-institucional e cultural (ROMANINI, 2007GIANNETTI; ALMEIDA, 2007) do curso. 


\section{Capítulo 5 - Design Universal (DU) para a Aprendizagem}

\section{1 - DU para aAprendizagem: Introdução, Conceituação e Histórico}

O conceito de DU para a Aprendizagem parte do pressuposto que a integração e a consideração de uma vasta gama de necessidades, observadas desde o início de um projeto, representa uma forma mais segura de beneficiar a totalidade do público ao qual ele se destina. Ele propõe que os recursos empregados na aprendizagem não sejam projetados especificamente para uma população, mas que permitam a utilização pela maior parcela possível de discentes, beneficiando pessoas de qualquer idade e habilidades (ORNELLA, STÉPHANIE, 2006).

O DU é definido pela ONU como a "concepção de espaços, artefatos e produtos que visam atender simultaneamente pessoas com diferentes características [...] constituindo-se nos elementos ou soluções que compõem a acessibilidade". De acordo com os pressupostos de sua conceituação, um projeto de DU precisatambém levar em consideração todas as ajudas técnicas que se fizerem necessárias para os grupos específicos, como é o caso das pessoas idosas ou com necessidades especiais (BRASIL, 2011).

Inúmeros pensadores e pesquisadores da área realizaram trabalhos voltados para a Tecnologia Assistiva, ferramentas de compensação (como correção ortográfica) e softwares de construção de competências, definindo-os como pontos importantes para qualquer plano de educação integral. Contudo, esses pensamentos tendiam a possuir um foco estreito, uma vez que ocultavam o papel crítico do ambiente na determinação de quem era ou quem não era considerado "deficiente". Por volta da década de 80 , percebeu-se a necessidade de mudar o foco para o currículo e suas limitações. Verificou-se que inúmeros alunos dotados, talentosos, com alguma necessidade especial ou particularmente vulnerável, estavam "à margem", e mesmo os alunos identificados como "médios" não tinham suas necessidades de aprendizagem atendidas devido ao projeto curricular considerado "pobre". Tal mudançaocasionou uma afirmação simples: o ônus da adaptação deve ser o primeiro colocado no currículo, não o discente, porque a maioria dos currículos são incapazes de se adaptar à variabilidade individual. É preciso reconhecer 
que os currículos, em vez dos alunos, são deficientes e, portanto, é preciso corrigi-los (MEYER; HITCHCOCK, 2005).

Já no início da década de 1990, diversas nações passaram a pesquisar, desenvolver e articular os princípios e práticas do DU para a Aprendizagem. Portanto, desde então já se passou a pensar na possibilidade de se estabelecerem currículos de acordo com o DU para a Aprendizagem para permitir a inclusão dos indivíduos com todos os tipos de habilidades, necessidades especiais, valores culturais e étnicos, estilos de aprendizagem e de Motivação (CAST, 2008; WAKEFIELD, 2011).

DU trata-se de um termo inspirado no conceito de desenho universal de desenvolvimento de produto e arquitetura pioneira por Ron Mace of North Carolina StateUniversity, em 1980. Esse movimento objetivou criar ambientes físicos, de forma que as ferramentas possam ser utilizadas por tantas pessoas quanto possível. No campo educacional, os pesquisadores procuraram, em decorrência de suas necessidades, abordar o problema por meio das ciências da aprendizagem, e não por intermédio de aplicação direta de princípios de arquitetura original (ROSE; MEYER, 2002).

Nesse contexto, pode-se compreender que a aprendizagem envolve desafio específico na área a ser aprendida. Para que isso ocorra, é preciso eliminar as barreiras desnecessárias, sem eliminar os desafios necessários para a concretização do processo de aprendizagem. Assim, os princípios do DU se concentram no acesso de todosa totalidade os aspectos da aprendizagem.

Reconhecendo os benefícios desta ideia, inúmeros educadores passaram, portanto, a empregar os conteúdos do DU para a Aprendizagem em suas práticas, com o intuito de flexibilizar e adaptar seus projetos, assegurar a aprendizagem independente de características específicas, minimizar dificuldades, considerar os atributos pessoais e satisfazer as necessidades únicas do maior número possível de alunos. A aplicação dos princípios do DU para a Aprendizagem às estratégias didáticas tem, nesse ensejo, o intuito de apoiar de forma democrática a aprendizagem dos alunos (MEYER; ROSE, 1998; 2005).

Além disso, o interesse em relação ao DU para a Aprendizagem é cada vez mais frequente, uma vez que o público que tem buscado os cursos de EAD 
é bastante heterogêneo, ou seja, com diversos tipos de habilidades e inabilidades. O currículo precisa ser apresentado em diversos formatos, meios de representação, de expressão e engajamento. A ideia é proporcionar que as atividades curriculares possam atuar sobre os seguintes sistemas neurais envolvidos na aprendizagem: sistemas de reconhecimento de padrões para identificação de objetos; sistemas estratégicos que nos informam como fazer as coisas; sistemas afetivos que determinam o que é importante e fornecem a Motivação para a aprendizagem (MEYER; ROSE, 2006).

Nesse contexto, a aplicação dos pressupostos do DU para a Aprendizagem ao promover uma aprendizagem flexível para múltiplos meios, multimídia, estratégias e ferramentas possibilita a editoração de materiais didáticos flexíveis que permitem aos alunos escolher e personalizar formatos adequados às suas necessidades de aprendizagem, por exemplo, em materiais digitalizados que podem apoiar os estudantes por meio de built-in (andaimes) ou sugestões, bem como contribuir para reconhecimento de palavras, decodificação e resolução de problemas (PISHA; COYNE, 2001); Ademais, a utilização da tecnologiapossibilita maior interação com os conteúdos (MCGLAUGLIN, apud MITCHELL; MYLES, 1998).

É necessário ainda considerar os seguintes elementos mediadores: elementos de linguagem e compreensão, elementos estruturadores, elementos motivadores e problematizadores, elementos de hipertextualidade e contextualização, elementos reforçadores da aprendizagem e elementos geradores de autonomia e sociabilidade, assegurando as legibilidades linguísticas (capacidade de um texto didático proximal/mediacional fazer-se prontamente inteligível ao leitor), técnica, científica e pedagógica (GUTIERREZ; PRIETRO, 1994).

É imprescindível, para o sucesso de projetos educacionais pautados nas ideias do DU, o apoio e investimento dos gestores das IES, a mobilização de uma infraestrutura física, técnica, bem como uma equipe multidisciplinar, a qual se responsabilizará pela concepção, tecnologia, produção, marketing, suporte tecnológico e avaliação decorrentes dos processos de editoração (BRASIL, 2007). Essa equipe contará com profissionais docentes especialistas, pedagogos, designers educacionais (instrucionais) e gráficos, programadores, animadores, advogados (direitos autorais) entre outros. 
Finalmente, o DU para a Aprendizagem abrange a avaliação continuada das disciplinas (componente do material didático - BRASIL, 2007), permitindo avaliar sem comprometer a validade e com mais precisão, as competências dos alunos (THOMPSON; JOHNSTONE; THURLOW, 2002) e possibilitando as acomodações que se fizerem necessárias, tais como a ampliação de testes, a leitura em voz alta de perguntas do teste aos estudantes, dentre outras (DOLAN; HALL, 2001).

Diante do exposto, o presente capítulo tem o intuito de esclarecer os benefícios que a aplicação do DU para a Aprendizagem na editoração de material didático pode provocar no processo de aprendizagem.

\section{2 - Paradigma da Inclusão no Brasil}

O movimento brasileiro de inclusão emergiu e ganhou força a partir do final da década de 80 e início da década de 90 . No âmbito do processo de ensino-aprendizagem, seu objetivo inicial era o de fundir o ensino especial com o regular; porém só passou a ser discutida efetivamente após a Conferência Mundial sobre Necessidades Educativas Especiais (UNESCO, 1994); tendo o Brasil, assim como outros países, pactuado e fixado o compromisso de reformular seu sistema de ensino, visando à garantia da inclusão, por meio do acesso de pessoas com deficiência no universo da escola comum, que garante juntamente com outros documentos o direito de todos à educação de qualidade (AMARAL et al., 2003).

O processo de inclusão é resultante da interação entre os fatores individuais e os referentes às peculiaridades do meio, que se manifestam em diferentes graus de acolhimento. Ou seja, a inclusão tem características dinâmicas resultantes da influência mútua de inúmeros fatores individuais e ambientais, facilitadores ou não da participação de pessoas com deficiência numa dimensão de inclusão/integração. [...] A presença de pessoas com deficiência na Universidade é, pois, um processo interativo, assegurado pelos direitos dessas pessoas à igualdade de oportunidades e à participação social (AMARAL, et al., 2011). 
Reconhece-se que o paradigma da inclusão, de maneira geral, defende a reestruturação do sistema de ensino, como um todo, e também da própria sociedade visando atender à diversidade, seja ela racial, cultural, de gênero etc. Assim, enquanto na perspectiva da integração, paradigma histórico anterior ao da inclusão, não há pressuposição de mudança do ambiente de aprendizagem e, consequentemente do ensino, diante da inclusão esta estabelece que a mudança é necessária, a partir da reformulação dos currículos, das formas de avaliar, da formação dos professores e de uma política educacional mais democrática (MITTLER apudMARTINS, 2009a).

Inúmeras leis e documentos internacionais subsidiam o paradigma da inclusão brasileiro, o qual teve sua gênese em lutas da sociedade por um governo democrático e capaz de assegurar os direitos dos cidadãos. Nesse contexto, a CF de 1988, fruto das relatadas lutas, em seus incisos, artigos e capítulos, possibilitou um novo olhar para o atendimento das pessoas com deficiência, assegurando o direito à sua reabilitação e integração à vida comunitária (BLATES, 2006).

Já em 1996, a promulgação da nova LDB, lei condizente com a CF que traz inovações tanto para a educação geral quanto à especial, traz um capítulo direcionado à educação especial permeando os princípios da inclusão dos alunos com deficiência e ampliação de oportunidade para todos, incluindo pessoas com ou sem necessidades ou habilidades especiais(PARANÁ, 2011).

Outro documento que ampara a educação inclusiva é a resolução CNE/CEB n. 2 de 11 de setembro de 2001, que também preconiza que o atendimento aos alunos com deficiência deve ser realizado em classes comuns do ensino regular (BLATTES, 2006).

Com isso, a educação especial passa, teoricamente, a perpassar todos os níveis, etapas e modalidades de ensino, oferecendo em cada uma delas recursos e apoio necessários para o atendimento educacional especializado voltado para contribuir com a aprendizagem e com o desenvolvimento da potencialidade dessa clientela incluída na escola de classes comuns, seguindo, além dos citados, os pressupostos das seguintes leis (BLATTES, 2006):

- Lei n. 8069/90 - ECA: lei que dispõe sobre a proteção integral à criança e ao adolescente. 
- Lei n. 10.098/00 - Acessibilidade: lei que estabelece normas gerais e critérios básicos para a promoção da acessibilidade das pessoas com deficiência ou com mobilidade reduzida, mediante a supressão de barreiras e de obstáculos nas vias e espaços públicos, no mobiliário urbano, na construção e reforma de edifícios e nos meios de transportes e de comunicação.

- Lei n. 10.436/02 - Libras: lei que reconhece a Língua Brasileira de Sinais como forma de meio legal de comunicação e expressão.

- Lei n. 7.853/89 - Corde: lei que oferece apoio às pessoas com deficiência.

- Lei n. 10.845: lei que estabelece o Programa de Complementação ao Atendimento Educacional Especializado às Pessoas com deficiência.

- Lei n. 10.172/01 - PNE: a partir da qual os Estados, o Distrito Federal e os Municípios passam a ser obrigados a, com base no PNE, elaborar planos decenais correspondentes.

Observa-se ainda que organismos internacionais como a Unicef e a Unescodesenvolvem um trabalho em relação à garantia de uma educação de qualidade que atenda a todas as pessoas, por meio de ações que visam chamar atenção em nível mundial sobre a importância desta temática, como resultados de tais ações ou reuniões; muito embora,no Brasil, tais programas ainda não estejam atingindo todos os sistemas educacionais, além denão estarem garantindo de fato ao professor uma capacitação suficiente para trabalhar com a diversidade (MANTOAN, 2005).

Diante de todos esses documentos e iniciativas de organizações internacionais, bem como dos princípios da educação inclusiva, as IES brasileiras se encontram diante do desafio de se reestruturarem para oferecer uma educação que corresponda às necessidades educativas de todos os alunos, visando à obediência aos princípios legais, respeitando as particularidades de cada um.

No entanto, não se trata apenas de garantir o direito ao acesso, mas também a permanência com sucesso. Neste caso, as IES precisam aprender com a convivência, por meio de um processo interativo, a trabalhar com as 
peculiaridades e individualidades dos agentes do processo ensinoaprendizagem. Assim, além de reconhecer o direito à igualdade de oportunidade criando alternativas pedagógicas adequadas, distintas que equiparem as condições das pessoas com deficiência às das pessoas que não se encontram em condições especiais, é necessário também garantir para todos uma permanência com sucesso no curso escolhido com a possibilidade de usufruir dos equipamentos e das condições necessárias para o alcance dos objetivos educacionais.

Defende-se aqui o potencial do DU para a Aprendizagem, permeando toda o projeto educacional, incluindo os materiais didáticos, como instrumento capaz de permitir a concretização do paradigma de inclusão.

\section{3 - Contextualizações da Aplicabilidade de DU na Aprendizagem}

$\mathrm{Na}$ educação, DU para a Aprendizagem representa um conjunto de princípios aplicáveis ao currículo que possibilita e fomenta o desenvolvimento de todos os indivíduos com igualdade de oportunidades. Significa, desse modo, uma mudança na maneira como pensamos sobre a aprendizagem e o ensino, em determinadas formas básicas.

No contexto da aprendizagem, uma definição concisa de DU foi proposta pelo OpportunityAct (2008, tradução nossa):

O termo Design Universal para Aprender, trata-se de um quadro cientificamente válido para orientar a prática educacional que prevê flexibilidade na forma como a informação é apresentada, na forma como os alunos respondem ou demonstram conhecimentos e habilidades, e nas formas de os alunos estão engajados, bem como reduz as barreiras no ensino, oferece acomodações adequadas, apoia e desafios, e mantém as expectativas de grandes realizações para todos os alunos.

Reconhece-se, neste contexto, que as pessoas possuem uma enorme diversidade de habilidades, necessidades e interesses de aprendizagem. As neurociências revelam que estas diferenças são tão únicas e variadas quanto nosso DNA ou impressões digitais (NCU, 2011). 
Nos currículos convencionais, em geral, discentes talentosos, com deficiência ou com habilidades/necessidades especiais tedem a ficar 'à margem' e mesmo os que são identificados como 'médios'em alguns casos podem não ter suas necessidades atendidas. Já com o DU para a Aprendizagem, espera-se o desenvolvimento de um currículo corrigido para se tornar flexível o bastante para acomodar todos os alunos (ROSE; SETHURAMAN; MELO, 2000).

Entende-se, desse modo, que as pessoas tendo ou nãodeficiências, podem apresentar diferentes habilidades mentais, psicológicas e físicas, as quais ainda sofrem variações no decorrer da vida, de acordo com o contexto e com o passar dos anos. Nesse ensejo, um modelo de DU para a Aprendizagem utilizado no estabelecimento de objetivos, métodos, materiais e avaliações para o processo de ensino-aprendizagem precisa ser flexível e capaz de se adaptar às necessidades individuais. Como resultado, a instrução é reforçada para todos os discentes (FLETCHER, 2002).

As deficiênciassão entendidas, portanto, não como algo a ser corrigido, mas como peculiaridades, características que precisam ser consideradas nos projetos educacionais a fim de que eles se tornem inclusivos, no sentido amplo, isto é, para todos!

Além disso, em ambientes formais de aprendizagem, tais como escolas e IES, o atual paradigma de inclusão propõe a ideologia de que ninguém pode ser selecionado ou segregado em função de suas diferenças individuais, sejam elas orgânicas, sociais ou culturais. Ele rompe, dessa forma, com a ideia de 'aluno padrão' e a suposição de que existe um processo único, 'normal' ou 'saudável' de ensino-aprendizagem para todos os sujeitos (GLAT; NOGUEIRA, 2002).

Assim sendo, o paradigma da inclusão não aceita a restrição a um modelo educacional único, constituindo-se em um modelo em que o respeito e a aceitação da diferença como condições constitutivas de uma sociedade plural são considerados nas ações curriculares (GLAT; FERNANDES, 2005).

A variabilidade individual precisa, portanto, ser a norma, e não a exceção. Nesse contexto, o DU para a Aprendizagem apresenta-se como opção adequada para criação de projetos flexíveis, com opções 
personalizáveis, que fomentam o progresso de todos os alunos (WAKEFIELD, 2011).

Em síntese, o DU para a Aprendizagem é um compromisso com a acessibilidade (THE CENTER FOR UNIVERSAL DESIGN, 2010) e apresentase em consonância com as tendências atuais de práticas inclusivas na concepção e efetivação dos projetos dos cursos superiores, além de estar em consonância com os requisitos e práticas indispensáveis na concepção, no planejamento, na preparação e na editoração de material didático.

\section{4 - Princípios do DU na Aprendizagem Aplicados ao Material Didático}

A educação do século XXI não objetiva simplesmente o domínio de conhecimento do conteúdo ou uso de novas tecnologias, mas se preocupa com o domínio e o sucesso do processo de ensino-aprendizagem (GREGIO, 2004).

A educação precisa, portanto, transformar os alunos novatos em discentes-pessoas que querem aprender, que sabem aprender estrategicamente, e que, com suas próprias formas individuais e flexíveis, estejam bem preparados para uma vida de aprendizagem. A aplicação dos princípios do DU para a Aprendizagem possibilita aos educadores o alcance do referido objetivo, proporcionando um enquadramento para a compreensão de como criar um currículo que atenda às necessidades de todos os alunos, desde o início do projeto (TAKAHASHI, 2000).

Ressalta-se, nesse contexto, os princípios do DU para a Aprendizagem (NCU, 2011):

- Princípio I - Utilizar múltiplos meios de representação do conteúdo.

- Princípio II - Utilizar diversos meios de ação e expressão;

- Princípio III - Oferecer diversas formas de engajamento.

\subsection{1 - Princípio I - Utilizar múltiplos meios de representação do conteúdo}

Os alunos diferem na maneira como percebem e compreendem as informações a eles apresentadas. Pessoas com deficiências sensoriais (cegueira, surdez, idosos etc.), transtornos de aprendizagem (dislexia, TDAH etc.) ou com diferenças de linguagem ou cultura podem requerer diferentes formas de representar um conteúdo, uma vez que uns podem construir 
conhecimentos de forma eficiente e eficaz por intermédio de meios visuais e/ou auditivos, ao invés de um texto impresso (NCU, 2011). Em suma, não há um meio de representação que será ótimo para todos os alunos. Assim, é fundamental fornecer diferentes opções de representação dos conteúdos.

Esse princípio do DU para a Aprendizagem possui três diretrizes:

- Diretriz 1 - fornecer opções para percepção: aprender é impossível se a informação estiver imperceptível para o aluno, e muito difícil quando ela se apresenta em formatos que exigem assistência ou esforços extraordinários. Dessa forma, é importante garantir que as informações-chave sejam igualmente perceptíveis para todos os alunos. Para tanto, é preciso fornecer as mesmas informações em diferentes modalidades (visão, audição ou tato), em formatos que permitam ajuste pelos usuários, como: ampliar o texto, amplificar sons, aumentar ou diminuir velocidade etc.(NCU, 2011; CAST, 2011).

- Diretriz 2 - oferecer opções para a linguagem, expressões matemáticas e símbolos: os alunos possuem variadas formas de entender conteúdos linguísticos e não-linguísticos. Um vocabulário pode aguçar a compreensão dos conceitos para um aluno estrangeiro e ser entediante e desmotivador para outro. Um sinal de igual (=) pode ajudar alguns alunos a entender que os dois lados de uma equação são equivalentes, contudo, o mesmo sinal pode causar confusão a um estudante que não entende o que ele significa. Uma imagem carrega um significado para alguns alunos; para outros, de diferentes origens familiares e culturais, podem transportar significados diferentes (NCU, 2011; CAST, 2011) etc.

- Diretriz 3 - fornecer opções para a compreensão: não basta que as informações estejam acessíveis, é preciso que os alunos as transformem em conhecimentos utilizáveis, o que acontece por meio de um processo ativo que demanda habilidades de processamento de informação, tais como: selecionar, classificar, categorizar, memorizar, integrar novas informações com conhecimentos prévios etc. Assim, a responsabilidade de 
qualquer currículo ou metodologia de ensino é a de fornecer os andaimes necessários para assegurar que todos os alunos tenham acesso ao conhecimento (NCU, 2011; CAST, 2011).

\subsection{2 - Princípio II - Utilizar diversos meios de ação e expressão}

Cada aluno expressa o que sabe e navega em um AVA de uma forma pessoal e peculiar. Nesse contexto, podem coexistir indivíduos com problemas significativos de movimento (deficiências físicas em geral, paralisia cerebral etc.), outros que lutam com habilidades estratégicas e organizacionais (distúrbios da função executiva), alguns que enfrentam barreiras linguísticas, culturais, dentre outros. Desse modo, determinados discentes poderão ser capazes de se expressar bem em texto escrito, enquanto outros utilizando-se da oralidade e vice-versa. Em síntese, não existe um meio de ação e de expressão que será ótimo para todos os alunos, portanto, fornecer opções de ação e de expressão é essencial para o alcance dos objetivos almejados em relação à aprendizagem de todos os alunos (NCU, 2011).

Suas diretrizes são:

- Diretriz 1 - fornecer opções de ação física: um livro ou pasta de trabalho impressos fornecem meios limitados de navegação ou interação física, uma vez que para utilizá-los é preciso virar páginas, escrever em espaços fornecidos e preestabelecidos, dentre outras ações. Inúmeras partes de um software educativo, de forma similar, também fornecem apenas meios limitados de navegação ou interação, por exemplo, a necessidade imprescindível de uso de mouse ou teclado etc. A navegação e a interação limitadas podem representar barreiras para alguns alunos (com deficiência física, cegueira, disgrafia etc.). É importante, portanto, fornecer meios e possibilidades com os quais todos os alunos possam interagir. Desse modo, os materiais didáticos precisam fornecer uma interface direta com as tecnologias de apoio por meio das quais os indivíduos, com alguma deficiência relacionada aos movimentos ou que prefiram uma forma alternativa de interação, possam navegar e expressar o que eles sabem; são exemplos: permitir a 
navegação ou interação por meio de opções de recursos de voz ativados, de aplicativos que permitam diferentes maneiras de participação, expandir teclados e outros componentes(NCU, 2011; CAST, 2011).

- Diretriz 2 - fornecer opções de expressão e comunicação: não há meio de expressão e comunicação que seja igualmente adequado para todos os alunos. Pelo contrário, há meios de comunicação que podem ser pouco adequados para determinados tipos de expressão e de aprendizagem. Exemplo: enquanto um aluno com dislexia pode sobressair ao contar histórias, ele pode ter grandes dificuldades para relatar a mesma história por escrito. Nesse ensejo, é importante fornecer diferentes alternativas para expressão e comunicação permitindo ao aluno diferentes possibilidades para expressar e compartilhar suas ideias, conceitos e conhecimentos no AVA (NCU, 2011; CAST, 2011).

- Diretriz 3 - fornecer opções para funções executivas: as funções executivas, ou seja, os níveis mais altos de capacidade e habilidade humana, permitem que os seres humanos superem impulsos, bem como as simples reações e ações de curto prazo para definir metas realizáveis em longo prazo, planejar estratégias eficazes para atingir esses objetivos, monitorar seu progresso e para modificar as estratégias, quando tais ações se fizerem necessárias, permitindo assim que tiremos proveito do ambiente em que estamos inseridos. Contudo, as referidas funções têm suas atividades drasticamente reduzidas, quando a capacidade de funcionamento executivo precisa ser dedicada à gestão de baixo nível, ou seja, às habilidades e respostas que não são automáticas ou fluentes, e quando a capacidade em si é reduzida devido a algum tipo de deficiência de nível superior ou de falta de fluência com estratégias executivas. Assim sendo, o DU para a Aprendizagem envolve esforços para expandir a capacidade executiva de duas maneiras: por habilidades de andaimes em menor nível, as quais exigem um processamento 
menos executivo; e por andaimes de competências mais elevadas, nível executivo, pautadas na aplicação de estratégias que sejam mais eficazes. Os primeiros referem-se às sugestões de ações que abordam andaimes de nível mais baixo. Já os segundos abordam maneiras de fornecer andaimes para funções executivas si (NCU, 2011; CAST, 2011).

\subsection{3 -Princípio III - Oferecer diversas formas de engajamento}

Os discentes têm formas diferentes de se comprometer e se motivar para aprender, as quais são baseadas em uma variedade de fontes (neurológicas, pessoais, subjetividade, conhecimento prévio etc.). Alguns são muito envolvidos pela espontaneidade e novidade, enquanto outros ficam desligados ou ansiosos na ocorrência desses aspectos, preferindo rotina e estabilidade. Há ainda alunos que preferem trabalhar sozinhos, enquanto outros preferem desenvolver atividades com seus pares. Assim, é preciso fornecer diferentes possibilidades para atender a essaspeculiaridades (NCU, 2011).

Suas diretrizes são:

- Diretriz 1 - oferecer opções de recrutamento: informações relevantes inacessíveis não desafiam cognitivamente os alunos, nem no presente, tampouco no futuro, uma vez que passam despercebidas e, portanto, não são processadas. Como resultado, os docentes precisam dedicar consideráveis esforços para conseguir a atenção e o engajamento dos discentes. Ao contrário, eles se atraem pelo que chama sua atenção e envolve o seu interesse. Observa-se que um mesmo aluno pode ser diferente ao longo do tempo, pois ele viverá em diferentes circunstâncias e ambientes, terá diferentes interesses, adquirirá novos conhecimentos e habilidades etc. É, portanto, fundamental oferecer alternativas para motivar os alunos de formas inter e intraindividual (NCU, 2011; CAST, 2011).

- Diretriz 2 - fornecer opções para sustentar o esforço, a persistência e a dedicação: muitos tipos de aprendizagem, em 
particular a aprendizagem de habilidades e estratégias, requerem atenção sustentada e esforço. Quando motivados a fazê-los, os alunos, de diferentes formas, poderão regular sua atenção, o que irá levá-los a sustentar o esforço e a concentração necessários para a aprendizagem. Essas formas diferenciadas refletem as disparidades de Motivação inicial, de habilidades para a autorregulação, de susceptibilidade à interferência contextual etc. Um objetivo-chave de instrução é desenvolver as habilidades individuais de autorregulação (diretriz 3), autoeficácia e autodeterminação que irão equalizar essas oportunidades de aprendizagem. Além disso, o ambiente externo precisa fornecer opções que igualem a acessibilidade apoiando os que apresentarem qualquer uma das particularidades citadas (NCU, 2011; CAST, 2011).

- Diretriz 3 - fornecer opções de autorregulação: embora seja importante fomentar a Motivação extrínseca para apoiar a Motivação e envolvimento (Diretrizes 1 e 2) dos alunos, também é fundamental oferecer possibilidades para que os discentes possam desenvolver as habilidades necessárias para regular suas próprias emoções e motivações. A capacidade de autorregulação contribuirá ainda para que o aluno possa regular suas reações e estados emocionais, a fim de utilizá-las de forma mais eficaz no enfrentamento e engajamento com o meio ambiente. Enquanto inúmeras pessoas desenvolvem habilidades de autorregulação por conta própria, seja por tentativa e erro ou pela observação de indivíduos bem sucedidos, outros têm dificuldades significativas no desenvolvimento dessas habilidades. O DU para a Aprendizagem, por meio de modelagem, propõe uma abordagem direta da autorregulação, a qual pode ser explicitada em uma variedade de métodos. Como em outros tipos de aprendizagem, as diferenças individuais são mais comuns do que uniformes. Uma abordagem bem-sucedida requer, portanto, o fornecimento de alternativas suficientes para apoiar alunos com aptidões e experiências anteriores diferentes 
para gerir eficazmente o seu próprio envolvimento (NCU, 2011; CAST, 2011).

\subsection{4 -Princípios do DU: contextualizações gerais e contribuições para o processo de aprendizagem}

Os três princípios do DU para a Aprendizagem dão uma visão inovadora acerca do currículo e da possibilidade de educar cada pessoa. A primeira delas é a de que eles são aplicáveis a todos os alunos, uma vez que se verifica incompatibilidade fundamental entre a população estudantil de hoje e os currículos padronizados (ROSE; MEYER, 2002).

Esses princípios se aplicam tanto aos materiais como às estratégias didáticas, os quais precisam ainda apresentar as seguintes características (W3C, 2011; CAST, 2011; NCU, 2011):

- Uso equitativo: ser útil para pessoas com diversas habilidades.

- Flexibilidade de uso: atender às preferências e às habilidades de uma grande variedade de pessoas.

- Uso simples e intuitivo: ser compreensível, independente da experiência, conhecimento, idioma ou nível de concentração do usuário.

- Informação perceptiva: comunicar uma informação independente das habilidades sensoriais do usuário ou das condições do ambiente.

- Tolerância ao erro: minimizar riscos e/ou consequências de ações indesejadas ou acidentais.

- Baixo esforço físico: ser confortável, eficiente e ocasionar o mínimo de fadiga.

- Dimensão e espaço para o uso e interação: apresentar dimensão e espaço apropriados para alcançar, manipular e usar independente do tamanho do corpo do usuário, postura ou mobilidade.

Reconhece-se que um ambiente padronizado de aprendizagem não é produtivo. Portanto, é vital e possível, com a tecnologia atual, reconhecer e atender às diferenças entre os discentes. O DU para a aprendizagem pode ser realizado, especialmente, de duas formas (ROSE; MEYER, 2002):

- aplicando a ideia de flexibilidade incorporada ao currículo do ensino; 
- apoiando não só a melhoria do acesso às informações dentro da sala de aula, mas também a melhoria do acesso à aprendizagem.

As orientações do DU para a Aprendizagem podem contribuir para a elaboração de planos de aula, recursos didáticos, ou para o desenvolvimento de programas (objetivos, métodos, materiais e avaliação) capazes de reduzir barreiras, bem como otimizar os níveis de desafio e de apoio, para atender às necessidades de todos os discentes. Além disso, possibilitam que os educadores consigam identificar os obstáculos dos currículos existentes e:

[...] podem reforçar a contribuição dos trabalhos pedagógicos e didáticos contemporâneos, pois permitem que sejam criadas situações de aprendizagem ricas, complexas, diversificadas, por meio de uma divisão de trabalho que não faz mais com que todo o investimento repouse sobre o professor, uma vez que tanto a informação quanto a dimensão interativa são assumidas pelos produtores dos instrumentos (PERRENOUD, 2000, p.139).

Dessa forma, verifica-se que o DU para a Aprendizagem traz mais um diferencial no processo de aprendizagem, proporcionando um resultado positivo tanto para o professor quanto para os alunos, isso porque é preciso considerar e inter-relacionar quatro componentes para compor um currículo com DU (UDL CENTER, 2011):

- Objetivos: representam o conhecimento, conceitos e habilidades que todos os alunos devem dominar e são, em geral, alinhados aos padrões. No âmbito DU para a Aprendizagem, representam as próprias metas articuladas de forma que reconheça a variabilidade aluno e diferencia acertos de meios. Essas qualidades permitem aos professores dos currículos DU para a Aprendizagem oferecer mais opções e variadas vias alternativas, ferramentas, estratégias e andaimes para alcançar o sucesso almejado. Considerandoo foco dos currículos tradicionais sobre as metas de desempenho ou de conteúdo, um currículo DU para a Aprendizagem se concentra no desenvolvimento de 'aprendizes de especialistas'. Define, portanto, as mais altas expectativas de cada aluno. 
- Métodos - decisões de instrução: trata-se de abordagens, procedimentos ou rotinas que professores especialistas usam para acelerar ou reforçar a aprendizagem. Os currículos com DU para a Aprendizagem facilitam uma maior diferenciação de métodos, com base na variabilidade aluno (aprendiz social / recursos emocionais) no contexto da atividade, da sala de aula e do clima. Flexíveis e variados, os métodos com DU para a aprendizagem são ajustados com base na monitorização contínua do progresso do aluno.

- Materiais: meios utilizados para apresentar o conteúdo de aprendizagem e que o aluno utiliza para demonstrar o conhecimento. No âmbito do DU para a Aprendizagem, a marca de materiais é a sua variabilidade e flexibilidade. Para a transmissão de conhecimentos conceituais, materiais com DU para a Aprendizagem precisam oferecer múltiplas mídias e conteúdos. Para o aprendizado estratégico e expressão do conhecimento, materiais com DU devem oferecer ferramentas e suportes necessários para acessar, analisar, organizar, sintetizar e demonstrar a compreensão de diversas maneiras. Para colaborar com a aprendizagem, materiais com DU para a Aprendizagem oferecem ainda caminhos alternativos para 0 sucesso, incluindo a escolha do conteúdo se for caso disso, vários níveis de apoio e desafio, e as opções de recrutamento e manutenção do interesse e da Motivação.

- Avaliação: processo de coleta de informações sobre o desempenho de um aluno usando uma variedade de métodos e materiais a fim de determinar conhecimento, habilidades e Motivação com o propósito de tomar decisões. No âmbito do DU para a Aprendizagem, o objetivo é melhorar a exatidão e a atualidade das avaliações, e para assegurar que eles são ampla e articulada o suficiente para guiar a construção dos conhecimentos de todos os alunos, ou seja, conseguir pelo foco focado na meta, como distinto do meio, permitindo a prestação de apoios e suportes para a construção de itens irrelevantes. Ao ampliar meios para acomodar alunos de variabilidade, as avaliações com DU para a Aprendizagem podem 
reduzir ou eliminar os obstáculos à medida exata do conhecimento, habilidades e compromisso de cada discente.

Verifica-se, assim, que o processo de aprendizagem é individual e único. Nele estão envolvidas três redes cerebrais primárias:

Figura 4Redes cerebrais envolvidas no processo de aprendizagem.

Recognition

Networks

The "what" of learning

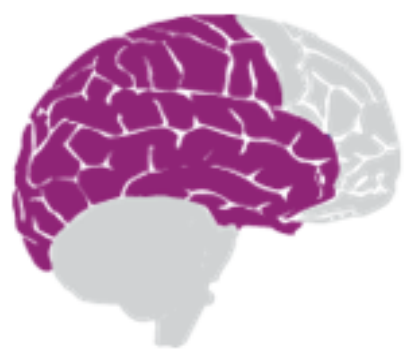

Strategic Networks

The "how" of learning

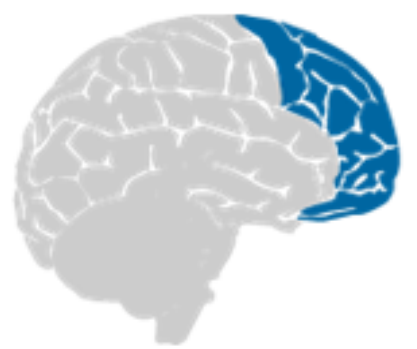

Affective Networks The "why" of learning

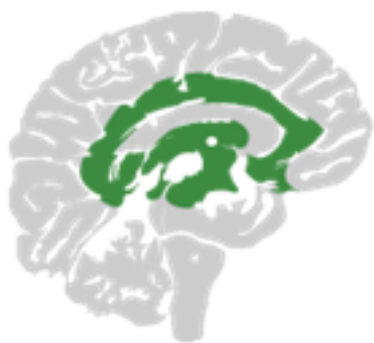

Fonte: NCU - National Center on Universal Design For Learning. Homepage. Disponível em: <http://www.udlcenter.org/aboutudl/whatisudl>. Acesso em: 9 abr. 2011.

Segue a tradução e a descrição de cada uma das referidas redes:

- Redes de conhecimentos (Recognition Networks) - 'o quê da aprendizagem': são especializadas nos sentidos e atribuem significado a padrões que vemos; elas nos permitemidentificar e compreender os conceitos, ideias e informações. Refere-se, portanto, à forma como percebemos e compreendemos as informações que nos são apresentadas, a maneira que utilizamos para reunir fatos e categorizar o que vemos, ouvimos e lemos. Exemplos: identificar letras, palavras ou estilo de um autor (NCU, 2011).

"O quê da aprendizagem" justifica a existência do primeiro princípio do DU aplicado ao contexto da aprendizagem: fornecer múltiplas formas de representação.

- Redes estratégicas (Strategic networks) - o 'como da aprendizagem': são especializadas para gerar e supervisionar os padrões mentais e motores. Elas nos permitemplanejar, executar e monitorizar ações e habilidades. Dizem respeito, assim, às maneiras como planejamos e executamos as tarefas, bem como às formas como organizamos e expressamos nossas ideias. Exemplos: 
escrever um ensaio ou resolver um problema de matemática (NCU, 2011).

O "como da aprendizagem" é responsável pela existência do segundo princípio do DU da Aprendizagem: fornecer múltiplas formas de ação e de expressão.

- Redes afetivas (Affective networks) - o 'porque da aprendizagem': são especializadas para avaliar os padrões e atribuir-Ihes significado emocional; elas nos permitem envolver com tarefas e aprendizagem e com o mundo que nos rodeia. Trata-se, assim, da dimensão afetiva, ou seja, estão ligadas à razão pela qual as pessoas se sentem desafiadas, se interessam e permanecem motivadas durante o processo de aprendizagem. Exemplo: avaliação continuada com possibilidades efetivas de sucesso (NCU, 2011).

O "porque da aprendizagem" dá origem ao terceiro princípio do DU na Aprendizagem: fornecer vários meios de engajamento.

Finalmente, observa-se que o papel da educação não se resume a simplesmente tornar um dado ou uma informação acessível, mas se preocupa também em possibilitar que uma informação acessível seja utilizada em um processo ativo de construção de conhecimentos utilizáveis, ou seja, na categorização estratégica de conceitos, na memorização ativa, no processamento seletivo das informações, na integração de novos dados com o conhecimento prévio etc.

Uma IES plural, para todos, por oposição à instituição elitista da era Vitoriana e à educação igualitária pós-revolução Francesa, tem por principal missão assegurar oportunidades iguais para cada um, atendendo às suas diferentes capacidades, desenvolvendo ao máximo o seu próprio potencial e a inclusão no grupo. As ajudas técnicas, entendidas como instrumentos de promoção desta igualdade de oportunidades, precisam ser desenhadas de forma a garantirem a sua função na realidade complexa e tantas vezes contraditória que é o ambiente formal de educação (ACESSIBILIDADE, 2011).

Desse modo, conceber, adaptar ou aplicarqualquer solução de tecnologia assistiva deve implicar e responsabilizar a teia de relações que o estudante estabelece na IES, sejam os docentes, os profissionais técnicos de 
apoio, os amigos ou a família e contribuir para explorar o seu potencial como pessoa, sem criar segregações ocultas (PRO-INCLUSÃO, 2011). 


\section{Capítulo 6 - Motivação e Autoeficácia para a Aprendizagem}

A Motivação e a Autoeficácia para a Aprendizagemtêm ganhado cada vez mais destaque na educação, uma vez que, de acordo com diferentes teorias, a ausência de uma delas pode representar queda de qualidade na aprendizagem.

Para contextualização, verifica-se que estudos sobre a Motivação têm versado sobre os aspectos cognitivistas, as motivações intrínseca e extrínseca, o uso de recompensas e metas de realização e as questões como organização da IES. Voltam-se ainda para questões relacionadas à inteligência, à ansiedade e à satisfação acadêmica. Além disso, os ambientes de aprendizagem têm sido entendidos como fatores preponderantes para o conhecimento sobre Motivação. O esforço, principal indicador de Motivação, só é utilizado se o aluno acreditar na sua capacidade de êxito (BORUCHOVITCH, 2001).

Nesse contexto, os projetos educacionais precisam desenvolver sua capacidade de diagnosticar as razões da ausência da Motivação do discente para a aprendizagem, analisá-lase buscar estratégias eficazes que ajudem a reverter esse quadro. Uma das razões para se resgatar essa Motivação está baseada na afirmação: "não só muda o que se aprende, como também a forma como se aprende. A aprendizagem também precisa evoluir" (POZO, 2002, p. $5)$.

Ademais, o intuito de aumentar os níveis de Autoeficácia para a Aprendizagem dos discentes nos impele a, portanto e dentre outros fatores, analisar as formas de aprender e pensar, para planejar e aplicar estratégias de ensino capazes de partir das condições efetivas de cada um para inseri-lo no processo de aprendizagem como agente. Eles precisam estar constantemente estimulados a refletir sobre as próprias percepções nos processos educacionais, bem como a aplicar seus esquemas cognitivos no intuito de avançar em suas formas de perceber a realidade, de aprender e de pensar (WERNECK, 2000). 


\section{1 - Motivação para a Aprendizagem}

Motivação é um termo derivado do latim 'movere' que tem sido amplamente estudado devido à sua grande importância para a compreensão sobre o comportamento humano. A representação mental de movimento consta em inúmeras definições eestá relacionada ao fato da Motivação conduzir uma pessoa a fazer algo, mantendo-a na ação e ajudando-a a concluir suas atividades (PINTRICH; SCHUNK, 2002).

Motivo + ação ou Motivação, como é conhecida, refere-se a um fator dinâmico da personalidade que existe em todos os seres humanos. Entendida como um processo causado por fatores conscientes e inconscientes, ela determina a direção, a intensidade e a persistência dos esforços que uma pessoa pode empregar para conquistar uma meta ou objetivo. Existem tanto a Motivação intrínseca como a extrínseca (RAMALHO, 2011).

A Motivação pode ser entendida ainda como uma tendência biopsíquica à continuidade e à constância física e mental da vida humana ou como uma força interna que emerge, regula e sustenta todas as ações que praticamos (RAMALHO, 2011; VERNON, 1973).

A Motivação representa, portanto, o elemento afetivo que impulsiona as estruturas do conhecimento, dando origem a um esforço a ser desenvolvido. Assim, quando um problema desafia a inteligência da pessoa, ela tem a necessidade de agir para restabelecer o equilíbrio (AZENHA, 2002).

Vários teóricos compartilham ainda a ideia de que a Motivação é "um fator interno que dá inicio, dirige e integra o comportamento de uma pessoa" (MURRAY, 1986 p. 20). Outra definição propõe que ela é um processo psicológico, uma força que tem origem no interior do indivíduo e que o empurra, o impulsiona a uma ação (GARRIDO, 1990). Além disso, "os motivos ativam e despertam o organismo, dirigem-no para um alvo em particular e mantém o organismo em ação" (PFROMM, 1987, p. 112).

Destaca-se, neste contexto, o entendimento de Piaget e Fraisse (1969) os quais inferem que o funcionamento da inteligência, depende, dentre outros fatores, de um motor que é afetivo (Motivação), pois, de forma geral, não se procura solucionar um problema que não tenha despertado o interesse. Portanto, para esses pensadores, a Motivação é o móvel de tudo, incluindo o 
processo de aprendizagem. Ressalta-se ainda a compreensão de Vygotsky (1991), o qual defende que o pensamento propriamente dito, entendido como uma das bases para a construção de conhecimento, é gerado por intermédio da Motivação, isto é, por meio de nossos desejos e necessidades, nossos interesses e emoções.

Observa-se que a Motivação é, portanto, um tema amplamente estudado e visto, por inúmeros teóricos, como central para a compreensão do comportamento humano, uma vez que sem ela seria difícil obter bons resultados nas atividades acadêmicas e que, independentemente da teoria que tomarmos como referência, é possível afirmar que a Motivação tem um papel fundamental na aprendizagem, isto é, ninguém aprende se não estiver motivado, se não desejar aprender!

Para o entendimento amplo da Motivação é preciso considerar elementos como: a necessidade de atividades físicas e mentais; as metas que fornecem ímpeto para direcionar a ação de um sujeito com base no que os indivíduos buscam evitar ou atrair ao realizar uma ação; e a noção de 'processo', ou seja, a Motivação como um processo e não um produto. Dessa forma não pode ser observada de forma direta, mas pode ser concluída com base em determinados comportamentos, além de ser responsável pelo início e pela sustentação de determinada ação (PINTRICH; SCHUNK, 2002).

Entende-se que seria complicado estudar Motivação de uma forma geral capaz de funcionar em todos os contextos, ou seja, para funcionar é preciso considerar o contexto que está sendo analisado: atlético, educacional, político etc. Sendo assim, poder-se-ia falar em Motivação para a educação, Motivação atlética, política, entre outras (HUGHES; REDFIELD; MARTRAY, 1989).

A Motivação acadêmica para a aprendizagem representa um componente de um constructo geral de 'Motivação para a realização"', a qual se insere no contexto mais amplo da Motivação (HUGHES; REDFIELD; MARTRAY, 1989). Para analisá-la, precisamos levar em consideração as singularidades do ambiente acadêmico que exige, em geral, processos cognitivos como a concentração, o processamento de dados para se obter informações, a capacidade de atenção, a resolução de problemas, o raciocínio etc. (BROPHY, 1983; BZUNECK, 2002). 
O interesse pelos aspectos motivacionais na aprendizagem está baseado em pesquisas relativamente recentes, as quais preconizam que a relação entre aprendizagem e Motivação vai além dessa pré-condição. Uma vez que ela é recíproca, a Motivação pode produzir um efeito na aprendizagem e no desempenho assim como a aprendizagem pode interferir na Motivação (PFROMM, 1987; SCHUNK, 1991; MITCHELL JR., 1992).

A Motivação é o fator que explica porque determinados estudantes aproveitam e gostam de sua vida acadêmica, desenvolvem seu potencial, apresentam comportamentos adequados, adquirem cada vez mais habilidades e capacidades; enquanto outros permanecem apáticos e desinteressados, por vezes até detestando sua vida acadêmica (GARRIDO, 1990; LENS, 1994).

Há, portanto, dois tipos de alunos: os extrinsecamente e os intrinsecamente motivados:

- Discentes extrinsecamente motivados: desempenham tarefas ou atividades propostas sempre pensando nas recompensas sociais (opinião alheia) ou externas (PFROMM, 1987; DECl, VALLERAND, PELLETIER, RYAN, 1991; LENS, 1994; PINTRICH E SCHUNK, 2002).

- Discentes intrinsecamente motivados: envolvem-se na elaboração e na manutenção da atividade pela tarefa em si, porque a considera interessante ou satisfatória. Dessa maneira, desenvolvem as atividades com afinco e dedicação (VALLERAND et al., 1992; PINTRICH, SCHUNK, 2002).

Estudos têm apontado a importância da Motivação acadêmica intrínseca para a educação. Os resultados obtidos demonstraram que pessoas com alta Motivação acadêmica intrínseca tendem a ter alta realização, percepções mais favoráveis da própria competência acadêmica, menos ansiedade e com menores exigências extrínsecas para realização de atividades de aprendizagem (GOTTFRIED, 1985; 1990; PINTRICH; DE GROOT, 1990).

Inúmeros estudos versaram ainda sobre a busca de possíveis fontes geradoras da Motivação intrínseca, dentre as quais, as mais importantes são: o desafio, a curiosidade, a fantasia e o controle sobre a ação (LEPPER et al. 1997). 
Os resultados apontam que os estudos sobre o tema não são totalmente conclusivos e que ainda há dúvidas sobre a relação entre as motivações intrínseca e extrínseca, especialmente no que se refere à influência de reforços e recompensas sobre a Motivação intrínseca (DECl, RYAN, WILLIAMS, 1996; PINTRICH, SCHUNK, 2002; MARCHESI, GIL, 2004).

Desse modo, este trabalho voltou-se para a identificação do tipo de Motivação que o recurso de aprendizagem com características do DU para a Aprendizagem tem potencial para ocasionar, entendendo que isso terá influência direta no sucesso dos processos de ensino e aprendizagem.

\section{2 - Autoeficácia para a Aprendizagem}

A Autoeficácia para a Aprendizagempode ser definida como uma crença funcional positiva que a pessoa tem em relação às próprias competências para controlar o seu processo de aprendizagem mediado por tecnologias educativas (COSTA, 2002). Em geral, o senso de autoeficácia influencia as aspirações, as escolhas e o nível de esforço empregado na execução de determinada atividade, assim como a resiliência e persistência diante das dificuldades (BANDURA, 1997).

A autoeficácia possui quatro fontes de origem que podem incidir de forma combinada ou independente: as experiências de êxito, as experiências vicárias, a persuasão verbal e os indicadores fisiológicos. Os discentes chegam a avaliar seu grau de eficácia durante toda a execução da tarefa (início, meio e fim) (BANDURA, 2002).

Afirma-se que as experiências de êxito são as fontes imprescindiveis e mais relevantes, pois as tarefas similares que proporcionam êxitos continuados passam para o discente a informação de que poderá obter êxito na realização de novas atividades. O mesmo acontece com as partes de uma tarefa. Quando se obtém êxito nas etapas anteriores, a pessoa desenvolve a crença de que tem capacidade para prosseguir. Não obstante, uma sucessão de fracassos também proporciona um resultado contrário, podendo deixar o indivíduo com um senso empobrecido de Autoeficácia para a Aprendizagem(SCHUNK, 1989; 2005).

A autoeficácia, ainda, requer que os sucessos sejam apontados pelos docentes, uma vez que é difícil um discente perceber seu progresso se este 
ocorrer de forma lenta ou não for apontado mediante o feedback positivo contingente (SCHUNK, 1989).

Fracassos anteriores estão associados à ansiedade comum gerada diante de novas atividades acadêmicas por afetarem a percepção de autoeficácia. Os fracassos fazem, portanto, que aconteça uma diminuição do senso de Autoeficácia para a Aprendizagemdos discentes tornando-os ansiosos. Contudo, se por alguma razão, os fracassos não consigam abalar a percepção de eficácia, os discentes não sofrem emoções negativas (MEECE, 1991). Dessa forma, uma autoeficácia reduzida no que se refere à capacidade de lidar com os desafios no ambiente acadêmico pode aumentar a probabilidade de ocorrência de ansiedade em situações como as relatadas.

A teoria de atribuição de causalidade defende que o sucesso ou o fracasso são, em geral, atribuídos a causas como: o esforço ou sua inexistência, a capacidade ou sua ausência, a facilidade ou dificuldade da atividade e a sorte ou o azar. Assim, a compreensão e atribuição de sucesso ou fracasso a uma experiência anterior, depende também do valor que o discente atribui ao evento, ao esforço e/ou à capacidade (WEINER, 1985).

Observa-se ainda que um sucesso que tenha sido alcançado com enorme esforço pode contribuir pouco para Autoeficácia para a Aprendizagem, uma vez que o discente pode entender que necessitou de muito esforço por não possuir as habilidades necessárias. Assim como, um sucesso alcançado em atividades consideradas extremamente fáceis tem menos possibilidades de promoverem crenças de autoeficácia (BANDURA, 1982; 2002).

Em síntese, verifica-se que o fator decisivo para o aumento de crenças de Autoeficácia para a Aprendizagem refere-se ao o modo como julgamos as causas dos eventos e, portanto, pouco importa a simples ocorrência anterior de fracassos ou sucessos (BANDURA, 1986).

Já as experiências vicárias, sugerem a um discente que ele também é capaz de superar desafios semelhantes, o que pode motivá-lo a iniciar as atividades. Contudo, se ele notar que seus pares não estão alcançando sucesso, provavelmente concluirá que ele também não terá êxito, caso acredite que seu nível é semelhante ao deles. Nesse caso, a previsão é de que não se empenhará na realização da atividade proposta. Inúmeras pesquisas experimentais com discentes universitários têm comprovado a influência da 
observação para as crenças de autoeficácia, todavia, enfatizam que essas experiências baseadas na observação (vicárias) podem representar uma força relativa e temporária de influência sobre a autoeficácia, uma vez que elas podem ser facilmente anuladas por experiências pessoais reais de fracasso (SCHUNK, 2001).

Ademais, observa-se que o que torna um modelo influente são certas características pessoais, entre as quais a de similaridade percebida pelo observador. Dessa forma, prevê-se que os sucessos de um docente em uma tarefa acadêmica tenha pouca ou nenhuma força de modelação sobre a maioria dos discentes, dado que estes percebem e ponderam diferenças de idade, de anos de estudo e de experiência (BANDURA, 1986).

De forma similar, é possível que inúmeros discentes atribuam o êxito de certos colegas a uma inteligência maior que a sua, o que os levará a desistir do esforço, tanto por acharem que ele será inútil, como também para não correrem o risco de parecerem menos capazes, pois esforço sem bons resultados seria interpretado como indicador de falta de capacidade. Portanto, também por esses motivos, a simples observação do êxito dos outros nem sempre é suficiente para alimentar as crenças de Autoeficácia para a Aprendizagem.

Outra fonte de Autoeficácia para a Aprendizagemé a persuasão verbal oral ou escrita. Com ela, os discentes podem desenvolver a Autoeficácia para a Aprendizagemquando Ihes for comunicado que eles possuem as habilidades e capacidades necessárias para realizar a atividade proposta. Entretanto, tais informações apenas serão convincentes se forem passíveis de comprovação em fatos e se partirem de alguém que realmente tenha credibilidade. Desse modo, poderão surtir efeito positivo inicial ler ou ouvir a frase "Você tem tudo para conseguir! Vamos lá!". Contudo, é preciso que as tentativas de realização das atividades não incidam em inúmeros fracassos para que a crença de Autoeficácia para a Aprendizagemnão entre em declínio (BANDURA, 2002).

As crenças de Autoeficácia para a Aprendizagemsão influenciadas ainda por um processamento cognitivo no qual o discente pondera as aptidões pessoais percebidas, as experiências passadas, bem como os componentes externos da situação, tais como: o nível de exigência do docente, as possíveis ajudas que pode receber e o grau de dificuldade de uma atividade. Ao 
emparelhar as potencialidades pessoais percebidas e as condições para a realização da atividade, o indivíduo realiza um julgamento, que pode ser positivo ou negativo, de suas próprias capacidades de obter sucesso ao se empenhar em realizar dada tarefa (BANDURA, 2002).

A crença de Autoeficácia para a Aprendizagempode ser entendida, portanto, como uma representação mental pessoal resultada de uma ponderação de fatores ambientais e pessoais.

\subsection{1 - Papel da Autoeficácia para a Aprendizagem no Processo de Aprendizagem}

A autoeficácia figura entre os fatores que compõem os mecanismos psicológicos da Motivação do aluno para a aprendizagem. Ela foi, inicialmente, conceituada, operacionalizada, pesquisada e impulsionada por Bandura (1977; 1986), que observou que a aplicação desse conceito no processo formal de ensino-aprendizagem direciona suas influências na Motivação e na aprendizagem do aluno (PINTRICH; SCHUNK, 1996).

O conceito de Autoeficácia para a Aprendizagemversa sobre as convicções pessoais em relação à crença na possibilidade de obtenção efetiva de sucesso na realização de uma determinada tarefa e em um grau de qualidade definida (SCHUNK, 1991). Nesse contexto, a definição mais aceita e utilizada pelos autores é a de Bandura (1986, p. 391), o qual defende que as crenças de autoeficácia são um "julgamento das próprias capacidades de executar cursos de ação exigidos para se atingir certo grau de performance".

Observa-se, portanto, que autoeficácia pode ser entendida como avaliação ou percepção pessoal quanto à própria inteligência, habilidades, conhecimentos entre outros aspectos, representados pelo termo capacidades. A questão não é de possuir ou não as referidas capacidades; não basta que estejam presentes, mas de a pessoa acreditar que as possua.

Ademais, são capacidades direcionadas para planejar, organizar e elaborar linhas de ação, ou seja, a expectativa de "eu posso fazer" que determinada a ação. Verifica-se ainda a existência de um componente de finalidade, por contemplar exigências de uma dada situação que precisam ser cumpridas. Desse modo, os discentes com uma crença positiva de Autoeficácia para a Aprendizagema atribui mental e simultaneamente ao objetivo de atender 
às exigências da situação, às potencialidades pessoais, bem como às ações que são necessárias e levem ao alcance do referido objetivo.

Chama-se a atenção para o fato de que a Autoeficácia para a Aprendizagemdiscrimina-se de outros tipos de expectativas também identificados em pesquisas sobre aprendizagem, particularmente 0 autoconceito e as autopercepções de competência e capacidade (BANDURA, 1986; PAJARES, 1996; 1997; SCHUNK, 1991). Esses dois últimos constructos, diferente da autoeficácia, por definição não se referem de modo específico a peculiaridades da situação e tampouco a ações a serem implementadas em uma tarefa analisada em detalhe.

Contudo, embora sejam distintos, reconhece-se que os referidos constructos não são antagônicos, uma vez que atuam de forma complementar: a autoeficácia é parte do autoconceito e também, sem autoconceito positivo quanto a uma área de atividade, não haverá aplicação de esforço, assim como não poderá faltar o julgamento de autoeficácia, que evidência aquela tarefa definida e circunstanciada.

Diante disso, pode-se afirmar que cada discente precisa ter crenças positivas de Autoeficácia para a Aprendizagemdiante de cada desafio acadêmico proposto e, simultaneamente, sentir-se capaz de controlar os resultados das próprias ações para obter sucesso nas atividades que executa (BANDURA, 1986; 1995; SCHUNK, 1991).

Finalmente, o tema em pauta vem sendo pesquisado na aprendizagem na modalidade EAD, cujos resultados demonstram que os alunos que possuem autoeficácia positiva, também assumem atitudes também positivas em relação ao uso de computadores para sua aprendizagem, além de autorregulação em sua aprendizagem e desempenho acadêmico. Conclui-se, desse modo, que a autoeficácia é uma variável de suma importância, que junto a outras dimensões da aprendizagem, é capaz de determinar o sucesso da aprendizagem na modalidade EAD (LEVINE, 1998; JOO, BONG, CHOI, 2000).

\section{3 - Autoeficácia e Motivação: Correlação e Importância para a Aprendizagem}

A Autoeficácia para a Aprendizagempode ser entendida, neste contexto, como uma crença nas capacidades pessoais para mobilizar a 
aprendizagem, os recursos cognitivos e para implementar ações que the permitam exercer controle sobre as atividades que the são exigidas (BANDURA, 2002); enquanto a Motivação trata-se de elemento imprescindível para o desenvolvimento humano, pois ela como defende teóricos como Piaget e Fraisse (1969) é o 'móvel' da aprendizagem. Sabe-se que a ausência da Motivação pode tornar difícil o cumprimento de determinadas atividades, tais como aprender, estudar etc. Ademais, ressalta-se que a Motivação pode ser intrínseca, decorrente de uma força interior e da capacidade pessoal que cada um tem de se motivar ou desmotivar ou extrínseca, gerada pelo meio ambiente no qual se encontra o indivíduo e os fatos e acontecimentos de sua vida pessoal.

Isso significa que os níveis de Motivação e os julgamentos de autoeficácia de uma pessoa podem determinar, dentre outros fatores seu nível de dedicação e sucesso, uma vez que é em função desses julgamentos que essa pessoa tem um incentivo para agir e imprime uma determinada direção a suas ações pelo fato de antecipar mentalmente o que pode realizar para obter resultados.

A Autoeficácia para a Aprendizageminfluencia, ainda, nas escolhas de linhas de ações, no apontamento e na definição de metas, no esforço e na perseverança empregados em busca do sucesso na realização dos objetivos; ao passo que, no contexto acadêmico, um aluno motiva-se e envolve-se nas atividades de aprendizagem apenas se acreditar que, com seus conhecimentos, talentos e habilidades será capaz de construir novos conhecimentos e aprimorar suas habilidades etc. (SCHUNK, 1991; PAJARES, 1997; BANDURA, 2002).

Dessa forma, ele seleciona atividades e estratégias de ação que, segundo prevê, poderão ser executadas por ele, e abandonará outros objetivos ou cursos de ação que não Ihe representem incentivo, porque sabe que não os poderá implementar. Com Motivação e consistentes crenças de Autoeficácia para a Aprendizagem, o esforço se fará presente desde o início e ao longo de todo o processo, de maneira persistente, mesmo que sobrevenham dificuldades e revezes.

Várias pesquisas versaram sobre relevância das crenças de autoeficácia sobre a Motivação e o desempenho acadêmico (PAJARES, 1996; 
1997; ZIMMERMAN, 2000), dentre os quais se concluiu que os discentes motivados e com índices positivos de autoeficácia obtiveram resultados melhores na solução de problemas do que outros discentes desmotivados ou com crenças mais enfraquecidas, bem como observaram que as crenças de autoeficácia prognosticavam mais seguramente o nível de performance nas aprendizagens, mesmo quando se controlavam variáveis como desempenho anterior e habilidades cognitivas (PINTRICH; SCHUNK, 1996).

A Motivação e a Autoeficácia para a Aprendizagemainda surtem efeito sobre a aprendizagem acadêmica autorregulada, uma vez que ao passo que a Motivação serve como móvel para a ação, as crenças de autoeficácia influenciam indiretamente no estabelecimento de metas, que é um dos componentes da autorregulação. Entende-se aprendizagem autorregulada como aquela em que o discente se mostra ativo, independente, motivado, autônomo e capaz de controlar suas ações sem significativas interferências externas (ZIMMERMAN, 2000; ZIMMERMAN, BANDURA, MARTINEZ-PONS, 1992).

Assim, especialmente a constatação de autoeficácia positiva se correlaciona com uso de estratégias e autorregulação, ou seja, a autoeficácia exerce um papel de facilitação do processo de engajamento cognitivo (PINTRICH; DE GROOT, 1990). Além disso, o conceito de autoeficácia influencia diretamente na seleção e na utilização de estratégias eficazes de aprendizagem e na Motivação, uma vez que leva os discentes a escolhas acertadas de cursos de ação diante das exigências acadêmicas, o que incidirá diretamente no nível.

Para tanto, o docente precisa proporcionar experiências de êxito aos alunos, evitando ocorrências que possam gerar dúvidas sobre suas capacidades pessoais e comunicando-lhes expectativas positivas em relação a elas (BANDURA, 2002). A literatura salienta ainda a importância de se trabalhar com determinadas metas que, enquanto processo cognitivo, tem potencial para afetar a Motivação, entendendo como meta aquilo que um aluno pretende cumprir ou atingir, as quais podem ser determinadas pelos discentes ou propostas pelos docentes (PAJARES, 1997).

Meta, como conceituado neste contexto, deriva da psicologia social, precisamente da Teoria do Estabelecimento de Metas de Locke e 
Latham(1994), a qual tem sido reconhecida como uma contribuição importante da psicologia da Motivação para os contextos educacionais, inclusive quando são focalizadas as crenças de autoeficácia.

A Autoeficácia para a Aprendizageme a Motivação dos alunos podem ser melhoradas se eles forem orientados pelo docente a realizarem atividades que representam metas a serem cumpridas. Tais metas ou atividades terão efeito motivacional se possuírem as seguintes características: ser específicas (definidas em seus detalhes de cumprimento - padrões bem definidos para a realização das atividades), próximas (cumpridas em curto espaço de tempo) e de nível adequado de dificuldade (desafios mais fáceis nas fases iniciais e mais difíceis nas fases subsequentes, desde que acessíveis mediante o esforço, que podem trazer informação sobre as verdadeiras capacidades) (BANDURA, 1993; PAJARES, 1997; SCHUNK, 1989; 1991, 2005).

Reconhece-se que crenças de autoeficácia e Motivação não são responsáveis pela solução correta de problemas, no entanto, em função dessas crenças, os discentes lançam mão de estratégias mais adequadas em busca da referida solução. Ademais, os resultados de pesquisas (op cit.) comprovam amplamente que discentes motivados aplicam esforço e não desistem, apesar de obstáculos e fracassos. Em suma, persistem enquanto não chegarem ao cumprimento final do desafio de aprendizagem proposto.

\section{4 - Aplicações da Autoeficácia para a Aprendizageme da Motivaçãono Material Didático}

$\mathrm{Na}$ tentativa de aumentar os índices de Autoeficácia para a Aprendizagem e de Motivação nos recursos didáticos, acredita-se que é preciso extinguir todas as formas de comparação social, uma vez que práticas que conduzam os alunos a se compararem com seus pares, podem fazer com que, caso os alunos se julguem menos capazes que os demais, tenham rebaixados seus índices de Motivação e a Autoeficácia para a Aprendizagem. Assim, no material didático, sugere-se evitar ações que visem: fomentar ritmo competitivo na realização das atividades acadêmicas, cobrar ritmo similar de produção da mesma atividade para todos os alunos e proporexplicitamente atividades diferentes para grupos de alunos em função da capacidade dos integrantes. Pode-se permitir que os alunos optem por atividades que ofereçam 
mais ou menos andaimes para a aprendizagem, permitindo que todos alcancem sucesso, por meio de resultados similares, mas não é recomendável rotular ou enquadrar alunos em grupos como 'melhores' ou 'piores' (WENTZEL, 1998; 2000; WOOLFOLK, 2000; BANDURA, 1986; 2002).

É preciso levar em conta que, ao empregar os mesmos materiais com a expectativa de atingirem os mesmos objetivos para um grupo de alunos, é provável que cada aluno realize as atividades em determinado nível de eficiência e eficácia. Nesse contexto, cada um e o grupo (como um todo) poderá desenvolver uma percepção de quem "é" mais e quem é menos capaz. Isso pode fomentar a concepção inadequada de que inteligência é uma entidade inalterável e fixa (ROSENHOLTZ; SIMPSON, 1984). Assim, gera-se uma mentalização compartilhada por todos de que há os mais e os menos capazes, fazendo com que os tidos como "menos capazes" sejam prejudicados em sua Motivação e rendimento, bem como tenham crenças reduzidas de Autoeficácia para a Aprendizagem (BANDURA, 1986; WENTZEL, 1998; 2000; WOOLFOLK, 2000). O DU para Aprendizagem, nesse contexto, sugere justamente o contrário, isto é, empregar o mesmo conteúdo de diferentes maneiras para que ele seja capaz de atender as especificidades, sempre que possível de todos os alunos, conduzindo-os ao sucesso.

O desenvolvimento das crenças de Autoeficácia para a Aprendizagemdepende ainda do desenvolvimento de estratégias de encorajamento, da apresentação de exemplos de outros discentes que, com características idênticas, já tenham atingido sucesso (experiências vicariantes), da chamada de atenção para os sucessos que os discentes vão atingindo ao realizar determinadas tarefas, bem como da interpretação de estados emocionais e fisiológicos para o desempenho de determinadas atividades.

Finalmente, observa-se que respeitar as características individuais, necessárias para fomentar a Motivação e a autoeficácia de cada discente, é fundamental para sua modelagem cognitiva, à medida que ela permeia a regulação e o controle pessoal do discente durante a construção do seu processo de aprendizagem. Nesse sentido, quanto mais um recurso didático tiver a capacidade de desenvolver a Motivação e as crenças positivas de autoeficácia em cada discente, mais ele será capaz de fomentar a aprendizagem (BANDURA, 2002). 


\section{Capítulo 7 - Metodologia}

O capítulo que se inicia descreve a metodologia empregada no presente trabalho. Explicita, portanto, as quatro propostas didáticas empregadas para implementar as diretrizes de dois princípios do DU para a Aprendizagem no material didático, os procedimentos de coleta, tabulação e análise dos dados, os instrumentos, o local, o tipo, os cuidados tomados, bem como a amostra e a caracterização que compõem a pesquisa.

Destaca-sea divisão em etapas, a qual torna factível o alcance dos objetivos almejados. Além disso, como a pesquisa não representa um processo completamente previsível e controlável, cada uma das referidas etapas foram continuamente refletidas, replanejadas e reinventadas ao longo do decurso de aplicação. A versão final está detalhada na Figura 7.

Figura 5Estrutura da pesquisa experimental.

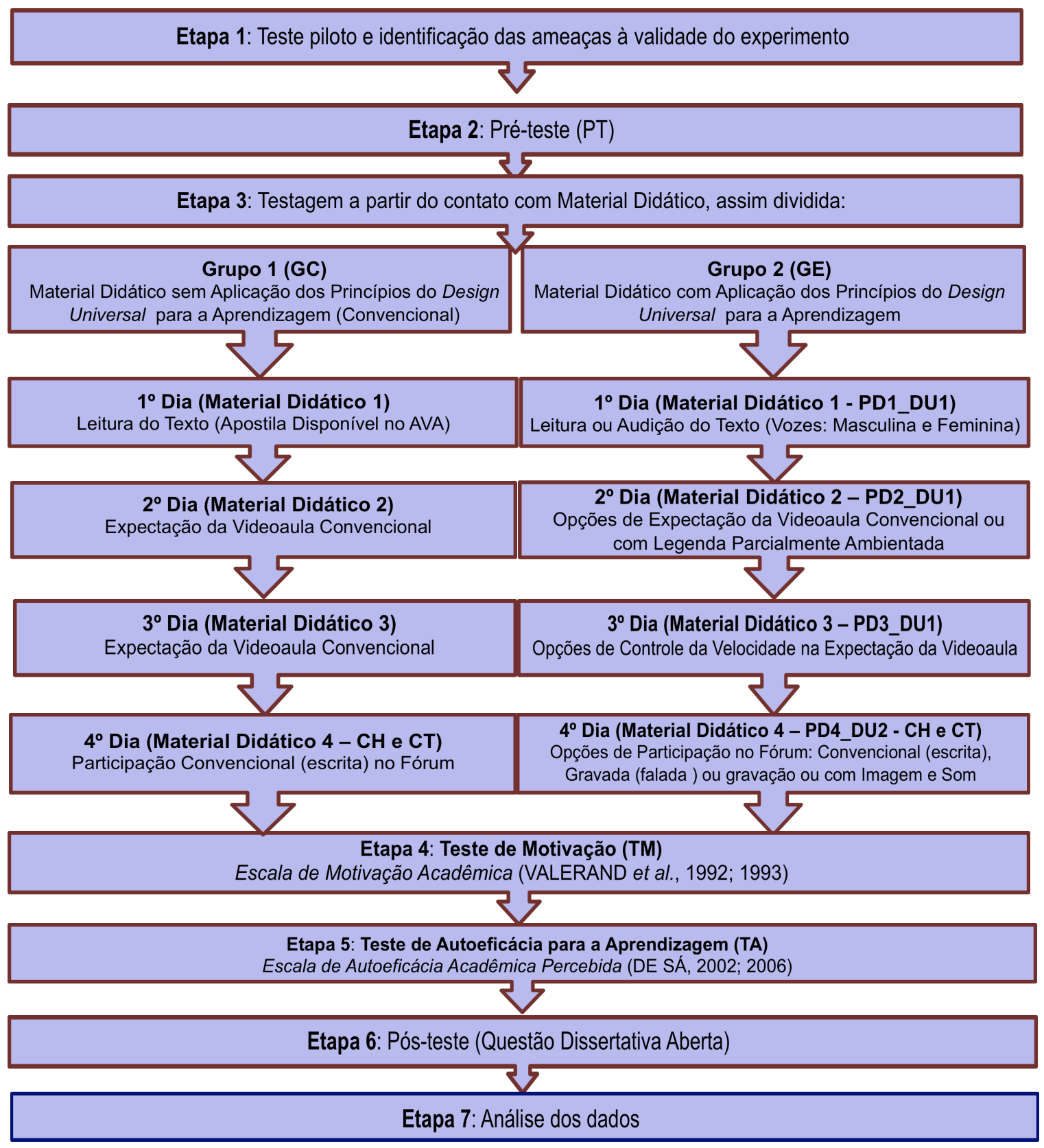

Fonte: Acervo Pessoal. 


\section{1 - Contextualização da Implementação das Estratégias do DU para a Aprendizagem no Material Didático}

As TIC's, em geral, muitas vezes são desenhadas esquecendo a diversidade de possibilidades de acesso que os vários utilizadores apresentam. Reconhece-se, no contexto do presente trabalho, que inúmeros estudantes apresentam dificuldades na utilização de recursos, métodos e/ou estratégias didáticas empregadas no processo de ensino-aprendizagem, em decorrência de necessidades ou habilidades pessoais específicas. Dessa forma, ao desenhar, projetar e elaborar materiais didáticos, é preciso prever-se uma série de possibilidades alternativas de acesso (ao nível do hardware e do software), contemplando a acessibilidade em suas múltiplas facetas. É importante que soluções inclusivas sejam implementadas desde o planejamento e, logo, ao nível do sistema operativo (PRO-INCLUSÃO, 2011).

Neste ensejo, segue descrição da incorporação das propostas didáticas no material didático, componente da presente pesquisa: as atividades iniciaram com a formalização da parceria com uma IESparticular do interior do estado de São Paulo (Brasil). Em um segundo momento, foi realizada, pelos pesquisadores junto a uma equipe multidisciplinar de profissionais, a escolha dos materiais didáticos das disciplinas, nos quais foram implementadas as propostas didáticas baseadas nas diretrizes que emergem dos princípios do DU para a Aprendizagem.

Prosseguindo, a terceira etapafoi a de efetiva produção do material didático com implementação de propostas didáticas. Ela foi arquitetada nas fases descritas a seguir:

- $1^{\text {a }}$ fase - preparatória: a equipe multidisciplinar de profissionais que atuam na produção de Material Didático da IES, junto com os pesquisadores, escolheram as quatro propostas didáticas que foram implementadas para atender, em parte, aos princípios I e II do DU (e as diretrizes) para a Aprendizagem.

- $2^{a}$ fase - implementação da primeira proposta didática baseada no Princípio I do DU para a Aprendizagem (PD1_DU1): disposição do conteúdo em texto e em áudio nas vozes masculina e feminina, cuja gravação foi realizada em estúdio, a partir de vozes humanas de profissionais escolhidos e experientes (um locutor de rádio e uma 
profissional da área de comunicação que já realiza este trabalho em uma IES pública). Os arquivos foram editados e convertidos para o formato de MP3 para posterior disponibilização aos alunos. Salientase que normalmente o conteúdo é apresentado para os discentes somente em texto para leitura em tela. Com a implementação desta proposta, o aluno pôde optar pela leitura em tela ou pela audição do texto nas vozes masculina ou feminina. Destaca-se ainda o potencial para portabilidade, uma vez que, partindo desta proposta didática, durante os estudos do curso, o aluno pode baixar o conteúdo no celular ou em outros aparelhos que permitem a reprodução com portabilidade.

Figura 8 Visualização do material didático com implementação da primeira proposta didática pautada no princípio I do DU para a Aprendizagem utilizado na realização do primeiro dia do experimento.

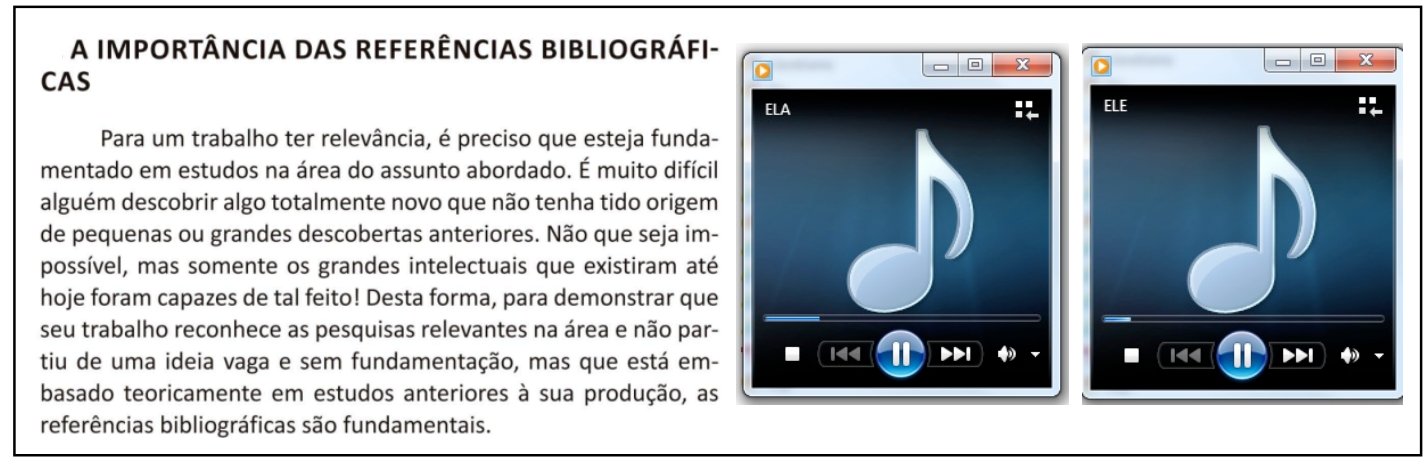

Fonte: Acervo Pessoal.

- $3^{\mathrm{a}}$ fase - implementação da segunda proposta didática baseada no princípio I do DU para a Aprendizagem (PD2_DU1): disponibilização de vídeos com legendas parcialmente ambientadas. A legenda foi editada por profissional de equipe técnica da IES (entretanto, pode ser realizada também a partir do uso de softwares, tais como, o "Subtitle Workshop 2.51") e alguns recursos de ambientação foram realizados de acordo com os pressupostos do INES (Instituto Nacional de Educação de Surdos) e da ABNT (ABNT NBR 15290:2005).Convencionalmente, a videoaula é apresentada de forma com recursos audiovisuais, sem opção de leitura. Com a implementação da segunda proposta, o aluno pôdeescolher se preferia assistir ao vídeo na versão convencional, com recursos 
audiovisuais, ou visualizá-la com o uso da legendadaparcialmente ambientada (sem áudio).

Figura 9 Visualização do material didático com implementação da segunda proposta didática pautada no princípio I do DU para a Aprendizagem utilizado na realização do segundo dia do experimento.

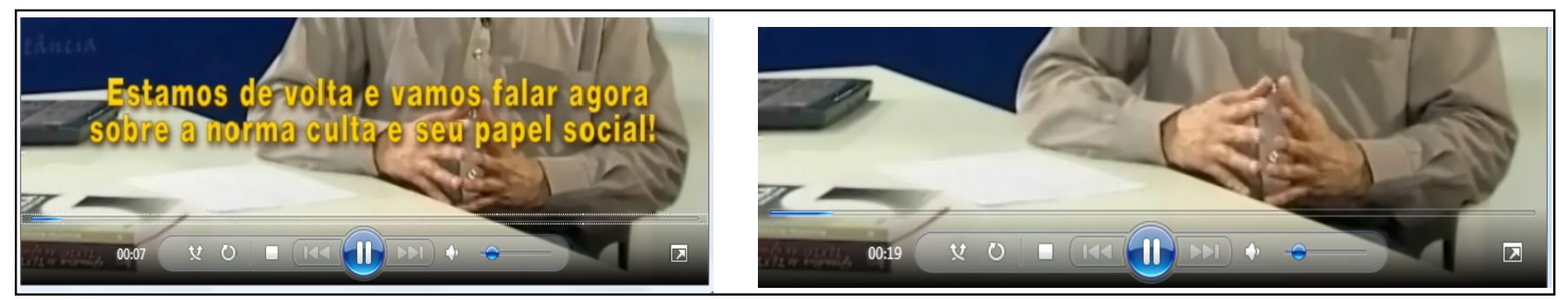

Fonte: Acervo Pessoal.

- $4^{a}$ fase - implementação da terceira proposta didática baseada no princípio I do DU para a Aprendizagem (PD3_DU1): incorporação de um software (Myspeed - Enounce) que permitiu o controle da velocidade e da apresentação geral dos conteúdos da videoaula. Normalmente, a videoaula é apresentada com velocidade constante, sem opções de adiantar ou voltar trechos do conteúdo. A partir da implementação desta proposta didática, o aluno teve a possibilidade de escolher a velocidade e a apresentação de reprodução da videoaula.

Figura 10 Visualização do material didático com implementação da terceira proposta didática pautada no princípio I do DU para a Aprendizagem utilizado na realização doterceiro dia do experimento.

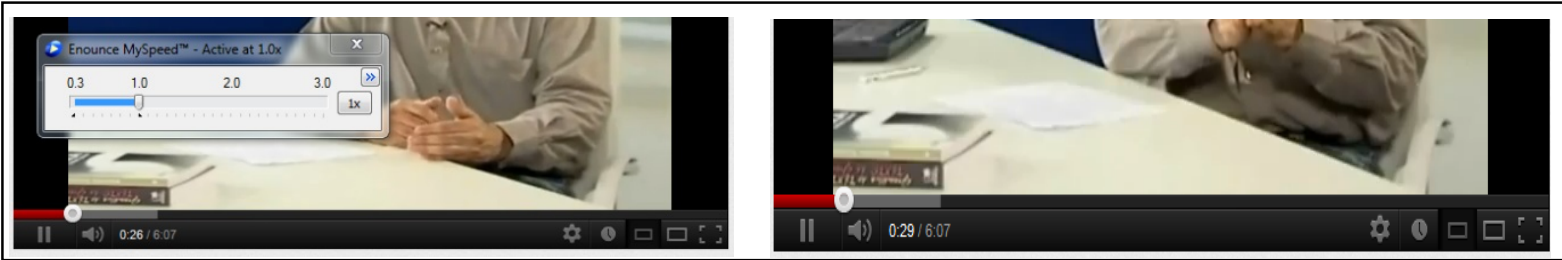

Fonte: Acervo Pessoal.

- $5^{a}$ fase - implementação da quarta proposta didática baseada no princípio II do DU para a Aprendizagem, para os alunos dos cursos de $\mathrm{CH}$ e CT, respectivamente (PD4_DU2CH/PD4_DU2CT): incorporação de um aplicativo (VoiceThread) que permitiu uma participação diversificada na ferramenta Fórum. Convencionalmente, a ferramenta de aprendizagem permite somente a participação escrita e a partir de um padrão único de navegação. Partindo da 
implementação desta proposta didática, o aluno pôde escolher a forma como quis participar da interatividade: de forma escrita, falada ou gravada com imagem e som.

Figura 11 Visualização da implementação da quarta proposta didática pautada no princípio II do DU para a Aprendizagem utilizado na realização do quarto e quinto dias experimento, nas turma de cursos na área de Ciências Humanas (licenciaturas) e Ciências Tecnológicas, respectivamente.
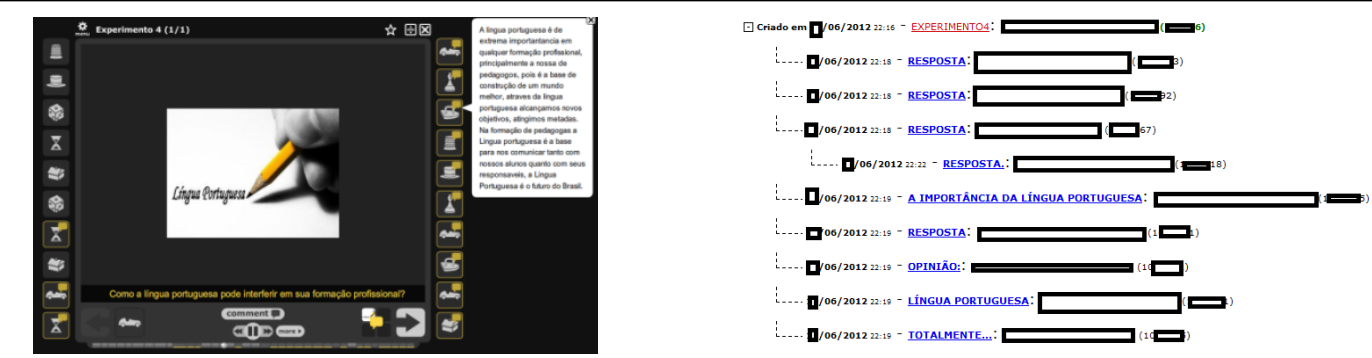

Fonte: Acervo Pessoal.

É válido salientar que a escolha das propostas didáticas (estratégias e softwares empregados) citadas foi realizada de forma integrada, com base na análise em dados estatísticos presentes na literatura sobre as escolhas comumente realizadas pelos alunos que realizam seus cursos na modalidade EAD (ABRAEAD, 2008), no relato da ponderação e do posicionamento de profissionais de diferentes áreas conhecimentos, tais como pedagogia, letras, comunicação, arte, TIC, programação, conteudistas, dentre outros. Para tanto, foram consideradas também as implementações com potencial de atender às necessidades específicas do maior grupo possível de discentes que compunham a amostra (representativa).

Além disso, é importante ressalvar que a produção do Material Didático com a implementação das estratégias descritasseguiu todas as suas etapas e cuidados, a descrição do processo de editoração do material, detalhado no Capítulo 4.

\section{2 - Procedimentos Experimentais}

Segue descrição dos procedimentos experimentais em etapas:

$1^{\text {a }}$ Etapa - teste piloto e ameaças à validade do experimento: o modelo de pesquisa escolhido para conduzir o experimento verdadeiro foi o de "Préteste/pós-teste". De acordo esse modelo, os indivíduos são designados ao 
acaso para compor oGE ou GC, os quais ficaram em ambientes separados. Primeiramente, os integrantes dos dois grupos foram submetidos ao pré-teste. Depois, o GE recebeu o material didático convencional e o material com tratamento experimental (propostas didáticas baseadas nos princípios I e II do DU para a Aprendizagem), para escolha de como preferiam interagir com os conteúdos, enquanto o GC recebeu apenas o material didático convencional dos cursos e ambos os grupos foram igualmente incentivados a construir conhecimentos sobre o material da disciplina, sem interferências ou explicações auxiliares. Ao final do contato com os materiais didáticos, os dois grupos participaram da testagem oficial e do pós-teste. Destaca-se que a aplicação desse modelo viabilizaum certo controle das fontes de invalidação, uma vez que tal prática pôde antecipar fatores que eventualmente interfeririam na validade interna do experimento, excluindo argumentações que poderiam vir contradizer a explicação de como as variáveis independentes afetaram as dependentes (SAMPIERI; COLLADO; LUCIO, 2006).

A referida antecipação são ações que compreendem efetivamente o teste piloto. No caso específico desta pesquisa, cada material desenvolvido passou por um teste inicial realizado uma única vez com alunos do curso de Licenciatura em Pedagogia da matriz da IES particular onde foram, posteriormente, realizados os experimentos oficiais (amostra: turma de 36 alunos, divididos aleatoriamente em dois grupos), como teste da aplicação e validação da estratégia e metodologia nos experimentos oficiais. Os alunos foram separados em duas turmas: uma delas, o GC, recebeu os quatro materiaisl em sua forma convencional; e a outra (GE) recebeu os materiais didáticos com a implementação das estratégias que permitiram optar por diferentes formas de interação para construção de conhecimentos: texto ou audição, videoaula com legenda, controle da velocidade e da apresentação da videoaula e participação diversificada no Fórum.

Após a explanação oral do condutor (docente da disciplina e/ou pesquisador) do experimento, os alunos responderam ao pré-teste e, em seguida, tiveram contato com o material didático. $O$ tempo oferecido foi de 35 minutos, com tolerância de até 40 minutos (os conteúdos disponibilizadosnos quatro materiais didáticos corresponderam a aproximadamentevinte minutos de dedicação). Em prosseguimento, os alunos responderam à Escala de 
Motivação Acadêmica eà Escala de Autoeficácia Acadêmica Percebida, respectivamente. Finalmente, foi realizada pelos pesquisadores uma questão aberta para responder oralmente. Nestes momentos, foram identificadas escolhas dos alunos, as falhas e as incoerências dos testes para posterior correção na testagem oficial. Dentre os fatores identificados, percebeu-se a necessidade de optar pela escolha de algumas questões ao aplicar o préexperimento, já que o teste completo ficou extenso para os alunos, dentre outras questões de ordem prática e operacional (ajuste de aplicativos, troca de fones e/ou outros instrumentos utilizados etc.); identificou-se ainda a necessidade de aplicar a entrevista (pós-teste) em questão aberta para o aluno relatar por meio da escrita, já que assimsentiam-se mais à vontade para relatar aberta e sinceramente seus pontos de vista sobre os questionamentos realizados.

Etapa 2 - PT: Pré-teste (Nível de Motivação e Autoeficácia para a Aprendizagem anteriores) - os níveis de Motivação e Autoeficácia para a Aprendizagem prévia do aluno foram determinados usando os dados obtidos a partir de um teste prévio (pré-teste). O pré-teste teve a função de medir se um participante já está motivado e/ou já se sentia capaz de aprender uma determinada disciplina simplesmente pela atratividade do conteúdo. Por meio da escolha aleatória de uma questão que representava cada tipo de Motivaçãoda tabela de autoria de Valerand e colaboradores (1992; 1993) e da escolha de algumas questões da escala de autoeficáciaacadêmica percebida (DE SÁ, 2002), os alunos apresentaram seus níveis de Motivação e autoeficácia para o estudo do conteúdo, respondendo a quatorze questões nototal. O nível prévio de Motivação e Autoeficácia para a Aprendizagem dos alunos foi identificado e comparado por meio de recursos estatísticos com os índices aferidos na testagem oficial. O pré-teste foi realizado por intermédio da utilização de instrumento on-line (SurveyMonkey).

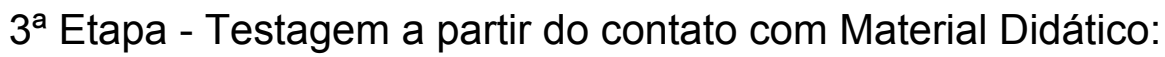

- $1^{\circ}$ Dia - Etapa 3a - Experimento 1: Grupo 1 (GC) - Material Didático convencional dos cursos, ou seja, sem aplicação dos princípios do DU para a Aprendizagem. Uma amostra de 29 alunos participantes dos cursos de Licenciatura em Pedagogia e Letras (disciplina de núcleo comum: Metodologia da Pesquisa Científica). Após escolha 
aleatória por sorteio, os alunos receberam algumas orientações práticas sobre os procedimentos a serem realizados e responderam ao questionário do pré-teste. Depois, tiveram acesso ao Material Didático para leitura em tela que comumente receberia no curso e foram incentivados a construir conhecimentos sobre o material da disciplina, sem qualquer interferência ou explicações auxiliares. Após um tempo de aproximadamente 20 minutos (para um conteúdo que exigia dedicação de aproximadamente cinco minutos), responderam àsEscala de Motivação Acadêmica e à Escala de Autoeficácia Acadêmica Percebida, respectivamente, conforme descrição nas etapas 4 e 5 . Ao final do teste, foi realizado um questionamento (pró-teste), conforme detalhamento apresentado na Etapa 6.

Ainda no $1^{\circ}$ Dia - Material 1 , simultaneamente, etapa 3b: Grupo 2 (GE) - Material Didático com aplicação da proposta didática 1, baseada no princípio I do DU para a Aprendizagem (PD1_DU1), ou seja, uma estratégia de flexibilização com as opções de leitura em tela ou audição do texto, nas vozes: masculina e feminina. Neste caso, os 29 alunos da mesma turma que não foram sorteados para compor o $\mathrm{GC}$ e, portanto, compuseram o GE, realizaram o pré-teste e tiveram contato com as mesmas orientações práticas, com osmesmos conteúdos e também foram igualmente incentivados a construir conhecimentos, sem qualquer interferência ou apoio auxiliares. Após um tempo de aproximadamente 20 minutos (para um conteúdo que exigia dedicação de aproximadamente cinco minutos), responderam àsEscala de Motivação Acadêmica e a Escala de Autoeficácia Acadêmica Percebida, respectivamente, conforme descrição nas etapas 4 e 5 . Ao final do teste, também responderam ao pós-teste, conforme detalhamento apresentado na Etapa 6.

- $2^{\circ}$ Dia - Etapa 3a - Experimento 2: Grupo 1 (GC) - Material Didático convencional dos cursos, ou seja, sem aplicação dos princípios do DU para a Aprendizagem. Uma amostra de 26 alunos de cursos de Bacharelado em Administração e de um Tecnólogo (disciplina de núcleo comum: Língua Portuguesa), após escolha aleatória por 
sorteio, compuseram o CG, participaram do pré-teste. Prosseguindo, tiveram acesso àvideoaula que comumente teria para o estudo da disciplina, com recursos audiovisuais e foram incentivados a construir conhecimentos sobre um conteúdo, sem qualquer interferência ou apoio auxiliares. Após um tempo de aproximadamente 20 minutos (para um conteúdo que exigia aproximadamente cinco minutos de dedicação), responderam àsEscala de Motivação Acadêmica e a Escala de Autoeficácia Acadêmica Percebida, respectivamente, conforme descrição nas Etapas 4 e 5 . Ao final do teste, participaram do pró-teste, conforme detalhamento apresentado na Etapa 6 .

Ainda no $2^{\circ}$ Dia, simultaneamente, etapa $3 b$ - Experimento 2: Grupo 2 (GE) - Material Didático com aplicação da proposta didática 2, baseada no princípio I do DU para a Aprendizagem (PD2_DU1), ou seja, escolha entre a videoaula convencional, com recursos audiovisuais ou uma videoaula, sem áudio, com inserção de legenda parcialmente ambientada. Neste caso, os 26 alunos das mesmas turmas que não foram sorteados para compor o GC, e portanto compuseram o GE, realizaram o pré-teste, tiveram contato com os mesmos conteúdos e também foram igualmente incentivados a construir conhecimentos, sem qualquer interferência ou apoio auxiliares. Após um tempo de aproximadamente 20 minutos (para um conteúdo que exigia aproximadamente cinco minutos de dedicação), responderam àsEscala de Motivação Acadêmica e a Escala de Autoeficácia Acadêmica Percebida, respectivamente, conforme descrição nas Etapas 4 e 5. Ao final do teste, participaram do pós-teste, conforme detalhamento apresentado na Etapa 6.

- $3^{\circ}$ Dia - Etapa $3^{a}$ - Experimento 3: Grupo 1 (GT) - Material Didático sem aplicação dos princípios do DU para a Aprendizagem. Uma amostra de 30 alunos de cursos de três licenciaturas (disciplina de núcleo comum), após escolha aleatória por sorteio, compuseram o GC e realizaram o pré-teste. Prosseguindo, tiveram acesso à videoaula que comumente receberia no curso e foram incentivados a construir conhecimentos sobre os conteúdos disponibilizados, sem 
qualquer interferência ou apoio auxiliares. Após um tempo de aproximadamente 20 minutos (para um conteúdo que exigia aproximadamente cinco minutos de dedicação), responderam àsEscala de Motivação Acadêmica e a Escala de Autoeficácia Acadêmica Percebida, respectivamente e conforme descrição nas Etapas 4 e 5 . Ao final do teste, os alunos participaram do pós-teste, conforme detalhamento apresentado na Etapa 6.

Ainda no $3^{\circ}$ Dia - Experimento 3, simultaneamente, etapa 3b: Grupo 2 (GE) - Material Didático com aplicação da proposta didática 3, baseada no princípio I do DU para a aprendizagem (PD3_DU1), ou seja, expectação de uma videoaula com possibilidade de controle da velocidade do vídeo. Neste caso, os 34 alunos das mesmas turmas que não foram sorteados para compor $\mathrm{O} G C$, e portanto compuseram o GE, realizaram o pré-teste. Prosseguindo, tiveram contato com os mesmos conteúdos e também foram igualmente incentivados a construir conhecimentos, sem qualquer interferência ou apoio auxiliares. Após um tempo de aproximadamente 20 minutos (para um conteúdo que exigia aproximadamente cinco minutos de dedicação), responderam às Escala de Motivação Acadêmica e a Escala de Autoeficácia Acadêmica Percebida, respectivamente, conforme descrição nas Etapas 4 e 5 . Ao final do teste, os alunos participaram do pós-teste, conforme detalhamento apresentado na Etapa 6.

- $4^{\circ}$ Dia - Etapa 3a - Experimento 4: Grupo 1 (GC) - Participação no Fórum convencional disponível na Sala de Aula Virtual. Uma amostra de 20 alunos de cursos de $\mathrm{CH}$ (licenciaturas -disciplina de núcleo comum), após escolha aleatória, fizeram o pré-teste e, depois, foram incentivados a responder um questionamento no Fórum, proposto pelo docente da disciplina, sem qualquer interferência auxiliar. Após um tempo de aproximadamente 20 minutos (para uma participação que exigia aproximadamente cinco minutos de dedicação), responderam àsEscala de Motivação Acadêmica e a Escala de Autoeficácia Acadêmica Percebida, respectivamente, conforme descrição nas Etapas 4 e 5.Ao final do 
teste, os alunos participaram do pós-teste, conforme detalhamento apresentado na Etapa 6.

Ainda no $4^{\circ}$ Dia - Experimento 4, simultaneamente, etapa 3b: Grupo 2 (GE) - Material Didático com aplicação da proposta didática 4 , baseada no princípio II do DU para a Aprendizagem (PD4_DU2CH), ou seja, interatividade no Fórum com opções de participação diversificada: escrita, falada ou gravada, com imagem e som. Neste caso, os 24 alunos da mesma turma que não foram sorteados para compor o GC e, portanto compuseram o GE, realizaram o pré-teste e foram incentivados a respondere a participar da interatividade proposta, respondendo a uma questão no Fórum que permitia participação escrita, falada ou gravada com imagem e som, sem qualquer interferência ou apoio auxiliares. Após um tempo de aproximadamente 20 minutos (para uma participação que exigia aproximadamente cinco minutos de dedicação), responderam às Escala de Motivação Acadêmica e Escala de Autoeficácia Acadêmica Percebida, respectivamente, conforme descrição nas etapas 4 e 5 . Ao final do teste, os alunos participaram do pós-teste, conforme detalhamento apresentado na Etapa 6.

- $5^{\circ}$ Dia - Etapa 3a - Experimento 4: Grupo 1 (GC) - Participação no Fórum da forma convencional que a referida ferramenta de aprendizagem se apresenta na Sala de Aula Virtual. Uma amostra de 10 alunos de cursos de $\mathrm{CT}$ (disciplina de núcleo comum), após escolha aleatória, compuseram o GC e realizaram o pré-teste. Prosseguindo, foram incentivados a responder um questionamento no Fórum, proposto pelo docente da disciplina, sem qualquer interferência ou apoio auxiliares. Após um tempo de aproximadamente 20 minutos (para uma participação que exigia aproximadamente cinco minutos de dedicação), responderam àsEscala de Motivação Acadêmica e a Escala de Autoeficácia Acadêmica Percebida, respectivamente, conforme descrição nas Etapas 4 e 5 . Ao final do teste, participaram do pós-teste, conforme detalhamento apresentado na Etapa 6. 
Ainda no $5^{\circ}$ Dia - Experimento 4, simultaneamente, etapa 3b: Grupo 2 (GE) - Material Didático com aplicação da proposta didática 4, baseada no princípio II do DU para a Aprendizagem (PD4_DU2CT), ou seja, interatividade no Fórum com opções de participação diversificada: escrita, falada ou gravada, com imagem e som. Neste caso, os 10 alunos da mesma turma que não foram sorteados para compor o GC e, portanto compuseram o GE, realizaram o pré-teste e foram incentivados a responder e a participar da interatividade proposta, respondendo a uma questão no Fórum que permitia participação escrita, falada ou gravada com imagem e som, sem qualquer interferência ou apoio auxiliares. Após um tempo de aproximadamente 20 minutos (para uma participação que exigia aproximadamente cinco minutos de dedicação), responderam às Escala de Motivação Acadêmica e Escala de Autoeficácia Acadêmica Percebida, respectivamente, conforme descrição nas etapas 4 e 5 . Ao final do teste, os alunos participaram do pós-teste, conforme detalhamento apresentado na Etapa 6.

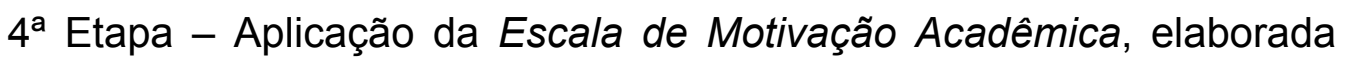
por Valerand e colaboradores (1992; 1993), a qual é constituída de 28 itens, subdivididos em sete subescalas: Motivação extrínseca, em três escalas, Motivação intrínseca, em três escalase desmotivação ou ausência de Motivação, em uma escala. Na Motivação extrínseca, foram analisadas a regulação por identificação: fiz porque quis fazer, a regulação por introjeção: fiz porque me obriguei a fazer, bem como a regulação externa: fiz porque me senti pressionado por outros. Já na Motivação intrínseca verificou-se a Motivação intrínseca para saber: fiz pela satisfação de aprender, explorar ou compreender, a Motivação intrínseca para realização: fiz porque gosto de realizar ou criar coisase a Motivação intrínseca para vivenciar estímulo: fiz para experimentar sensações estimulantes, de natureza sensorial ou estética. Finalmente, foi analisada a desmotivação, que implicaausência de percepção de contingências entre as ações e seus desfechos: falta/ausência de motivos intrínsecos ou extrínsecos. Para a elaboração da referida escala, Vallerand e colaboradores (1986) estudaram a construção e as propriedades psicométricas de um instrumento para medir a Motivação acadêmica. Os sujeitos da pesquisa 
foram 746 universitários canadenses que foram submetidos à aplicação da EME separadamente em três grupos durante o período de aula. A um grupo, a escala foi aplicada duas vezes para determinar a estabilidade do instrumento. Os resultados confirmaram a existência de sete subescalas que capazes de avaliar três tipos de Motivação interna: para conhecer, para experimentar sensações e para realização; e outros três tipos de Motivação externa, a saber, externa, introjetada e regulação identificada. Apresentou ainda uma escala de a-Motivação e o número total de itens foi 28. Em um estudo posterior, Vallerand e colaboradores (1992) se propuseram a validar a mesma escala. Os resultados revelaram que a escala apresentou níveis satisfatórios de consistência interna e estabilidade temporal no período de um mês. Além disso, a análise fatorial confirmatória corroborou a estrutura obtida de sete fatores. Além disso, o formato para Educação Superior do instrumento foi traduzido para o Português, usando-se procedimentos apropriados para tradução transcultural. A versão utilizada nesta pesquisa lista 28 itens que podem representar razões para o aluno continuar seu curso de EAD (Anexo I).

Outros trabalhos também se preocuparam em testar a consistência interna e a estabilidade da Escala de Motivação Acadêmica, por meio da utilização de procedimentos estatísticos. A versão do instrumento utilizada neste trabalho, a qual foi traduzida, apresentou características semelhantes ao original no que concerne à consistência interna, ainda que os valores sejam um pouco inferiores. Na validação da consistência interna, o resultado foi "Alpha =0,87" (NORMAN, STREINER, 1994; STREINER, NORMAN, 1995; MURPHY; ALEXANDER, 2000; ZIMMERMAN, 2000; ALONSO, 2006). Um terceiro trabalho, por meio da análise dos 28 itens do questionário Escala de Motivação Acadêmica, também obteve um coeficiente Alpha de Cronbach de 0,87 . O valor médio dos índices de (Alpha) de consistência interna das subescalas foi de "0,72 - variando entre 0,67 (Motivação intrínseca para realização) e 0,79 (desmotivação)". Os autores demonstram ainda que "as correlações entre as subescalas acompanham o denominado modelo simplex descrito por Vallerand e cols. (1993), com algumas restrições". Além disso, "os componentes de Motivação intrínseca mostram correlações elevadas entre si, bem como correlações negativas com a subescala de desmotivação". Observou-se, porém, forte associação entre as subescalas de Motivação de saber e de 
realização; tal associação, no âmbito educacional, indica uma complementaridade entre a satisfação de aprender algo novo e a realização de criar e participar além das atividades mínimas requeridas pelas IES (FALCÃO, ROSA, 2008, p. 10).

$5^{\mathrm{a}}$ Etapa - Aplicação da Escala de Autoeficácia Acadêmica Percebida no formato de julgamento dual, que é uma criação de De Sá (2002; 2006), com base nos procedimentos e proposições sugeridos por Bandura (1997). Ela é constituída por 20 itens que permitem, de acordo com a dinâmica inerente daEducação Superior, apurar se os indivíduos se sentem mais aptos a dar conta das tarefas que Ihe são propostas. Esta escala, para indicar (mensurada em gradações que variam de 0 a 100) a força da autoeficácia percebida no domínio acadêmico, leva em consideração que os discentes apresentem determinadas competências trabalhadas nos níveis de formação educacional precedentes. Os desafios propostos aos discentes devem ser classificados quanto à engenhosidade, ao exercício intelectual, às precisão, produtividade, ameaça e autorregulação exigida e suas análises devem ser apresentadas em termos de "consigo fazer", e não de "farei" (BANDURA, 1997). Salienta-se ainda que os indivíduos são solicitados a julgarem suas capacidades operacionais tal como acreditam que se encontram no momento, não em suas capacidades potenciais (Vide Anexo II).

A validação deste instrumento e seu uso com universitários se tornou objeto de estudo de pesquisadores. Eles evidenciaram as relações existentes entre o constructo investigado, o desempenho acadêmico e a interação interpessoal. Por meio de técnicas correlacionais simples e da análise fatorial, "constatou-se a existência de quatro fatores principais (Eigenvalue e"1) e se confirmaram a consistência interna $(\mu=0,902)$ e a estabilidade do instrumento $(r=0,723 ; p<0,01)$ ". Observa-se, assim, que o referido instrumento é mais um recurso para detectar e aprimorar as capacidades e competências acadêmicas e sociais, viabilizando a superação de dificuldades intra e interpessoais previamente adquiridas que possam prejudicar o desempenho e comprometer tanto as possibilidades de escolha profissional como a própria realização pessoal (DE SÁ, 2006).

$6^{a}$ Etapa - Pós-Teste: entrevista - resposta a uma questão aberta: momento em que o pesquisador teve a oportunidade de observar os 
fenômenos tais como eles se produziram em seu contexto natural, para, então, analisar os resultados de forma mais crítica, atribuindo um teor qualitativo ao trabalho.

$7^{\text {a }}$ Etapa - Análise dos dados: os resultados obtidos em uma abordagem multimodal consideraramuma comparação entre os alunos do GE, que utilizarammateriais didáticos com aplicação dos princípios de DU para a Aprendizagem e os alunos do GCque utilizaram os materiais didáticos comumente aplicados nos respectivos cursos (sem aplicação das propostas didáticas). Além disso, foram comparados os resultados de cada aluno com os apresentados por ele mesmo (pré-teste $\mathrm{x}$ teste oficial), antes e após o contato com os materiais didáticos.

No que concerne à quantificação dos dados estatísticos, adotamos como nível de significância $p \leq 0,05$ para análise dos percentuais alcançados a partir do contato com os materiais didáticos que atendiam a todas as propostas didáticas implementadas nos materiais didáticos (PD1_DU1/ PD2_DU2/ PD3_DU3/ PD_DU4CH-CT). Na comparação do GC com o GE, primeiro, testamos se as variáveis possuíam ou não distribuição normal através do teste de Kolmogorov-Smirnov e, de acordo com os índices alcançados, nas variáveis com distribuição normal aplicamos o teste de $t$ de Studentpara amostras independentes; para as variáveis rejeitadas aplicamos o teste não-paramétrico de Mann-Whitney. Ademais, na comparação dos índices relevantes alcançados nos pré-testes com os testes realizados após o contato com o material didático, utilizamos o teste não-paramétrico de Wilcoxon para amostras pareadas. Ressalta-se que, o subgrupo escolhido foi representativo no que se refere à população, o que permitiu a realização de algumas prospecções e generalizações dos resultados.

Para o enfoque qualitativo consideramos o mesmo conjunto de pessoas, o qual representa uma amostra da própria população estudada, inserida em seu contexto (universo), isto é, são alunos que já cursam disciplinas em cursos superiores na modalidade EAD, portanto, apresentam uma bagagem de experiência em relação a essa modalidade (SAMPIERI; COLLADO; LUCIO, 2006). Nota-se que essa população foi delimitada com base em parâmetros amostrais de ambos os enfoques e situou-se claramente 
ao redor de suas características de conteúdo, de lugar e de tempo (BAPTISTA, 1983).

\subsection{1 - Contexto}

As propostas didáticas foram implementadas nos materiais didáticos das disciplinas de núcleo comum: Tecnologia Educacional para EAD, Língua Portuguesa e Metodologia da Pesquisa Científica. A aplicação das escalas e as entrevistas foi realizada ao final do primeiro semestre de cinco cursos de licenciaturas (Computação, Educação Física, Pedagogia e Letras), um bacharelado (Administração) e um tecnólogo(Gestão em TI).

\subsection{2 - Amostra}

A amostra foi selecionada de acordo com os pressupostos do tipo probabilístico estratificado, ou seja, a população foi dividida em segmentos e foi selecionada uma amostra para cada um deles. Foi assim realizado porque,embora todos os elementos da população possuam possibilidade similar de serem escolhidos, se faz imprescindível a estratificação da amostra em relação às categorias que se apresentam na população, cujos estratos, no que se refere a essa pesquisa, foram os diferentes cursos, nos quais estão inscritos os discentes que compõem a amostra.

A unidade de análise da população e a amostra que participaram do experimento totalizaram 238 discentes participantes de cursos superiores de uma IES particular no primeiro semestre do ano de 2012. A amostra era composta por $66 \%$ de pessoas do sexo feminino e $34 \%$ de pessoas do sexo masculino, com idademédia de 31 anos. Salienta-se que a instituição oferece 26 cursos de Graduação presenciais e 30 cursos de Graduação na modalidade EAD nas áreas de Educação, Saúde, Administração, Religião e Tecnologia. Oferece, anualmente, um conjunto de 40 a 50 cursos de Pós-graduação (Especialização - lato sensu) nessas mesmas áreas e diversos cursos de Extensão Universitária, contando atualmente com um número significativo de alunos, distribuídos em polos de apoio presencial espalhados em todo o território nacional.

A amostra foi, portanto, dividida em dois grupos: GE e GC. Ambos foram avaliados nas variáveis Motivaçãoe Autoeficácia para a Aprendizagem. 


\section{3 - Contextualizações metodológicas}

O presente trabalho é uma pesquisa aplicada de natureza experimental, uma vez que intentouencontrarsoluções para problemas concretos e relacionadas à prática (ANDRADE, 2001); procurou investigar conhecimentos com potencial para efetiva aplicação prática na busca pela solução de problemas específicos, os quais foram relatados nos capítulos iniciais (GIL, 1991); buscou executar uma ação, manipulando intencionalmente as variáveis independentes para observar e analisar seus possíveis efeitos e consequências sobre as variáveis dependentes, agregando a esses resultados um elemento qualitativo por considerar a relação dinâmica existente entre o mundo real (objetivo) e a subjetividade do sujeito (BABBIE, 2001; GIL, 1991; SAMPIERI; COLLADO; LUCIO, 2006).

No que se referiu à abordagem do problema, ao optar por um modelo multimodal, a pesquisa pautou-se, portanto, nas vertentes quantitativa e qualitativa, concomitantemente. Assim, ao passo que se utilizou predominantemente técnicas estatísticas, traduzindo, em números, opiniões e informações para classificá-las, também observou-se os fenômenos, tais como eles se produziram em seu contexto natural, para, então, analisar os resultados. Com isso, pretendeu-se generalizar os resultados de maneira mais ampla, exercendo um controle e um ponto de vista de contagem e magnitude sobre os fenômenos, possibilitando réplicas e enfoques sobre pontos específicos de tais fenômenos e comparações com estudos análogos, ao mesmo tempo em que procurou a realização de uma pesquisa flexível, explicitando o ponto de vista do pesquisador de forma holística recente e natural ao analisar a profundidade dos dados, a riqueza interpretativa, a dispersão, os detalhes, as experiências únicas e a contextualização do ambiente (SAMPIERI; COLLADO; LUCIO, 2006).

Em relação aos objetivos, a pesquisa apresentou uma abordagem exploratório-explicativo-descritiva, isso porque realizou-se um levantamento histórico e uma revisão da literatura para proporcionar maior familiaridade e compreensão mais precisa em relação ao problema estudado. Buscou ainda explicar os fatores que contribuíram para a ocorrência dos fenômenos, além de 
descrever as características da população, o fenômeno e o estabelecimento de relações entre variáveis, dentre outros aspectos relevantes (GIL, 1991).

Quanto aos meios de investigação, a pesquisa é teórico-históricoempírica, uma vez que o problema foi inserido dentro de um quadro de referências teóricas, que buscou recuperar a evolução do tema, explicar os fatores determinantes e as implicações das mudanças dos meios de investigação, bem como explicar como o problema vem sendo pesquisado do ponto de vista metodológico, explicando os procedimentos, os fatores, as propostas, a analise de resultados e a sua generalização que normalmente são empregados no estudo do problema (GIL, 1991; LAKATOS; MARCONI, 1991).

Finalmente, a pesquisa foi delineada como um experimento verdadeiro. Portanto, reúne dois requisitos para obter o controle e a validade interna: os grupos de comparação (manipulação dasvariáveisindependentes) e a equivalência de grupos. Além disso, utilizou-se de pré e pós-testes com o objetivo de analisar a evolução dos grupos antes e depois do tratamento experimental (SAMPIERI; COLLADO; LUCIO, 2006).

A combinação das diferentes metodologias com a utilização do método dedutivo de caráter teórico, conceitual e científico para a pesquisa histórica, e comparativo para o experimento (ALAVI, CARLSON, 1992; RICHARDSON, 1999) representarão, portanto, o cerne da pesquisa.

\subsection{1 - Modelo Experimental Aplicado}

A presente pesquisa, como um experimento verdadeiro (SAMPIERI; COLLADO; LUCIO, 2006), pautou-se na realização da manipulação intencional das variáveis independentes - material didático instrucional com aplicação das quatro propostas didáticas que atendem aos princípio I e II do DU para a aprendizagem, para medir o efeito delas sobre as variáveis dependentes Motivação e Autoeficácia para a Aprendizagem, controlando a validade interna da situação experimental.

O modelo escolhido foi o de pré-teste/pós-teste com dois grupos equivalentes (similares entre si e em relação aos aspectos relativos ao desenvolvimento experimental exceto na manipulação da variável independente) para análise comparativa dos resultados quantitativos. Salientase que os grupos escolhidos (conforme descrição no tópico 
denominadoAmostra) por distribuição aleatória (considerado o método mais preciso e confiável para tornar os grupos equivalentes), ou seja, ao acaso, o que permite que o experimento não seja afetado por variáveis estranhas, sejam elas conhecidas ou desconhecidas. Optou-se pela distribuição aleatória utilizando pedaços de papel, nos quais foram escritos os nomes dos discentes para posterior execução de um sorteio simples e às cegas(SAMPIERI; COLLADO; LUCIO, 2006).

\section{4 - Definição das variáveis}

- Variáveis Independentes: materiais didáticos com aplicação de quatro propostas didáticas que atendem aos princípios I e II do DU para a Aprendizagem (PD1_DU1: texto com opções de leitura ou áudio com voz feminina ou masculina/ PD2_DU1: opção entre expectação da videoaula convencional - recursos audiovisuais - ou expectação da videoaula - sem áudio - com legenda parcialmente ambientada/ PD3_DU1: opção entre a expectação da videoaula na velocidade convencional ou controlando a velocidade / PD4_DU2CH-CT: fórum com opções de participação escrita, falada ou gravada com imagem e som).

$\checkmark$ GE: utilização de material com implementações das propostas didáticas que atendem aos princípios I e II do DU para a Aprendizagem.

$\checkmark$ GC: utilização de material didático convencional dos cursos.

- Variáveis dependentes: Motivação e Autoeficácia para a Aprendizagem.

\section{5 - Hipóteses}

Considerando a amplitude do tema tratado no trabalho, foi preciso delimitá-lo para conseguir mensurá-lo. A delimitação resultou no tema da presente pesquisa. Nesse contexto, considerando as variáveis e os instrumentos utilizados na pesquisa, foram formuladas as seguintes hipóteses:

- H01: a aplicação de cada uma das propostas didáticas no material didático e em um momento específico de avaliação (avaliação 
continuada colaborativa), realizada com base nos princípios I e II do DU para a Aprendizagem, tem potencial para ampliar os índices de Autoeficácia para a Aprendizagem dos discentes;

- H02: a aplicação de cada uma das propostas didáticas no material didático e em um momento específico de avaliação (avaliação continuada colaborativa), realizada com base nos princípios I e II do DU para a aprendizagem, tem potencial para ampliar os índices de Motivação intrínseca e extrínseca dos discentes;

- H03: a aplicação de cada uma das propostas didáticas no material didático e em um momento específico de avaliação (avaliação continuada colaborativa), realizada com base nos princípios I e II do DU para a aprendizagem, tem potencial para diminuir os índices de desmotivação dos discentes.

\section{6 - Fidelidade ou Precisão, Consistência dos Procedimentos}

A fidelidade associada aos instrumentos foi testada por pesquisadores em trabalhos devidamente realizados e publicados. Além disso, previu-se a realização de um pré-teste com a intenção de minimizar e adequar eventuais erros na aplicação.

\section{7 - Manipulação do Experimento: Modalidade de Entrega das Informações}

Foram consideradas, para a análise, as variáveis Motivação e Autoeficácia para a Aprendizagem.

Durante a preparação, teste e análise, foram tomados determinadoscuidados para se evitar as fontes de invalidação interna, tais como a maturação, a instabilidade dos participantes, a administração dos testes, a instrumentalização, a seleção, a mortalidade experimental, bem como a interação entre seleção e maturação, dentre outras interações. Os participantes não foram informados sobre as condições experimentais para garantir a veracidade das conclusões (SAMPIERI; COLLADO; LUCIO, 2003). Verificou-seainda durante a realização da pesquisa, precauções como: consulta aos experimentos anteriores, avaliação da manipulação antes de 
proceder ao experimento, bem como a inclusão de verificações para a manipulação.

\section{Capítulo 8 - Resultados e Análise dos Resultados}

No capítulo que ora se inicia, serão demonstrados e analisados os resultados obtidos a partir da realização dos experimentos, tanto os estatísticos (relacionados à parte quantitativa da pesquisa), quanto os da entrevista (parte qualitativa da pesquisa).

Espera-se, assim, o entendimento da variância dos índices efetivos de Motivação e de Autoeficácia para a Aprendizagem alcançados diante da aplicação das quatro propostas didáticas pautadas na aplicação dos princípios I e Il do DU para a aprendizagem (Modelo NCU).

Para cada uma das quatro propostas didáticas empregadas no material didático, inicialmente, foi realizada a análise quantitativa dos dados obtidos por intermédio da aplicação dos instrumentos estatísticos: Escala de Motivação Acadêmica (VALLERAND et. al., 1992; 1993) e Escala de Autoeficácia Acadêmica Percebida (DE SÁ, 2002) e, posteriormente, uma análise qualitativa, na qual é discutido o contexto em que se inserem experimentos, partindo das considerações descritas pelos agentes envolvidos na pesquisa.

8.1 - Proposta Didática 1 inspirada no Princípio I do DU para a Aprendizagem (PD1_DU1) - Escolha entre Leitura ou Audição de um Texto (opção por Voz Feminina ou Masculina)

\subsection{1 - Experimento 1: Comparação entre os GE e o GC}

A tabela a seguir, apresenta as escolhas dos discente-participantes do GE para acesso aos conteúdos:

\begin{tabular}{|c|l|c|c|}
\hline \multicolumn{1}{|c|}{$\begin{array}{c}\text { ESTRATÉGIAS ESCOLHIDAS PELOS DISCENTE- } \\
\text { PARTICIPANTES - GE }\end{array}$} & \multirow{1}{|c|}{ DESCRIÇÃO } & $\%$ \\
\hline C & \multicolumn{1}{|c|}{ DES } & & \\
\hline 1 & Texto (leitura) & 2 & 6,9 \\
\hline 2 & Audição com voz feminina & 15 & 51,7 \\
\hline 3 & Audição com voz masculina & 5 & 17,2 \\
\hline 4 & Leitura + Audição com voz feminina & 3 & 10,3 \\
\hline 5 & Leitura + Audição com voz masculina & 1 & 3,4 \\
\hline 6 & $\begin{array}{l}\text { Audição com voz feminina + Audição com voz } \\
\text { masculina }\end{array}$ & 2 & 6,9 \\
\hline 7 & $\begin{array}{l}\text { Leitura + Audição com voz feminina + Audição } \\
\text { com voz masculina }\end{array}$ & 1 & 3,4 \\
\hline
\end{tabular}

Seguem, abaixo, os resultados comparativos entre os GE e o GC. 
Inicialmente, testamos se as variáveis possuíam ou não distribuição normal através do teste de Kolmogorov-Smirnov:

\begin{tabular}{|l|r|r|}
\hline & $\begin{array}{c}\text { Kolmogorov- } \\
\text { Smirnov Z }\end{array}$ & \multicolumn{1}{|c|}{$\mathbf{p}$} \\
\hline AUTOEFICÁCIA &, 744 &, 636 \\
\hline MECE & 1,152 &, 141 \\
\hline MEINTRO &, 976 &, 297 \\
\hline MEIDEN & 1,562 &, 015 \\
\hline MIVE &, 659 &, 778 \\
\hline MIR & 1,262 &, 083 \\
\hline MIS &, 819 &, 513 \\
\hline DES & 1,455 &, 029 \\
\hline
\end{tabular}

De acordo com os índices alcançados, rejeitamos a normalidade das variáveis MEIDEN, no GE e DES, em ambos os grupos (GE e GC) eutilizamos para elas o teste não-paramétrico de Mann-Whitney. Nas demais, aplicamos o teste de $t$ de Student para amostras independentes.

Seguem resultados e análise por variável:

- AUTOEFICÁCIA: $\mathrm{t}=2,74 \quad \mathrm{p}=0,008^{*}$ Portanto, verifica-se diferença significativa, O GE possui valores significativamente superiores.

- MECE: $t=1,02 \quad p=0,31$ Não há diferença significativa.

- MEINTRO: $t=1,88 \quad p=0,07$ Não há diferença significativa.

- MEIDEN: $Z=1,48 \quad p=0,14$ Não há diferença significativa.

- MIVE: $t=1,49 \quad p=0,14$ Não há diferença significativa.

- MIR: $t=1,66 \quad p=0,10$ Não há diferença significativa.

- MIS: $t=0,42 \quad p=0,68$ Não há diferença significativa.

- DES: $Z=1,21 \quad p=0,23$

- Não há diferença significativa.

Verificam-se intervalos de confiança de $95 \%$ para as diferenças de médias:

\section{t-test for Equality of Means} 95\% Confidence Interval of the Difference 


\begin{tabular}{|l|r|r|}
\hline \multicolumn{1}{|c|}{ Dimensões } & \multicolumn{1}{c|}{ Lower } & \multicolumn{1}{c|}{ Upper } \\
\hline AUTOEFICÁCIA & 0,12578 & 0,81215 \\
\hline MECE & $-0,26586$ & 0,81758 \\
\hline MEINTRO & $-0,0308$ & 0,97908 \\
\hline MEIDEN & $-0,1304$ & 0,87178 \\
\hline MIVE & $-0,13096$ & 0,88958 \\
\hline MIR & $-0,09512$ & 1,00892 \\
\hline MIS & $-0,42906$ & 0,6532 \\
\hline DES & $-0,54074$ & 0,38557 \\
\hline
\end{tabular}

Seguem, finalmente, as estatísticas descritivas:

\begin{tabular}{|c|c|c|c|c|c|c|c|c|c|}
\hline \multicolumn{2}{|c|}{ GRUPO } & AUTOEFICACIA & MECE & MEINTRO & MEIDEN & MIVE & MIR & MIS & DES \\
\hline \multirow{5}{*}{ Experimental } & Median & 4,15 & 4,5 & 4,5 & 4,75 & 3,75 & 4,25 & 4 & 1,25 \\
\hline & Minimum & 2,15 & 1,5 & 2,5 & 1,75 & 1,5 & 1,25 & 1 & 0,75 \\
\hline & Maximum & 4,9 & 5 & 5 & 5 & 5 & 5 & 5 & 4,25 \\
\hline & Mean & 4,0362 & 4,1207 & 4,2759 & 4,3534 & 3,5776 & 3,9741 & 3,7586 & 1,6121 \\
\hline & $\begin{array}{l}\text { Std. } \\
\text { Deviation }\end{array}$ & 0,5928 & $1,02 \mathrm{E}+00$ & 0,76282 & 0,90514 & 0,96848 & 1,00744 & 1,12497 & 0,96729 \\
\hline \multirow{5}{*}{ Controle } & Median & 3,6 & 4,25 & 4 & 4 & 3,25 & 3,75 & 3,5 & 1,25 \\
\hline & Minimum & 1,75 & 1,5 & 1 & 1,75 & 1,5 & 1,75 & 1,75 & 0,75 \\
\hline & Maximum & 4,75 & 5 & 5 & 5 & 5 & 5 & 5 & 3,75 \\
\hline & Mean & 3,5672 & 3,8448 & 3,8017 & 3,9828 & 3,1983 & 3,5172 & 3,6466 & 1,6897 \\
\hline & $\begin{array}{l}\text { Std. } \\
\text { Deviation }\end{array}$ & 0,70689 & $1,04 \mathrm{E}+00$ & 1,12277 & 0,99761 & 0,97142 & 1,08958 & 0,92224 & 0,78392 \\
\hline \multirow{5}{*}{ Total } & Median & 3,925 & 4,25 & 4,25 & 4,375 & 3,5 & 4 & 3,75 & 1,25 \\
\hline & Minimum & 1,75 & 1,5 & 1 & 1,75 & 1,5 & 1,25 & 1 & 0,75 \\
\hline & Maximum & 4,9 & 5 & 5 & 5 & 5 & 5 & 5 & 4,25 \\
\hline & Mean & 3,8017 & 3,9828 & 4,0388 & 4,1681 & 3,3879 & 3,7457 & 3,7026 & 1,6509 \\
\hline & $\begin{array}{l}\text { Std. } \\
\text { Deviation }\end{array}$ & 0,6885 & $1,03 E+00$ & 0,98096 & 0,96244 & 0,98026 & 1,06529 & 1,02111 & 0,87351 \\
\hline
\end{tabular}

8.1.2 - Experimento 1: Comparação dos índices identificados no Pré-teste e os alcançados após o contato com o Material Didático

\section{* Grupo Experimental (GE)}

A tabela a seguir apresenta os índices alcançados nos pré-testes em comparação aos testes realizados após o contato com o material didático, para a qual utilizamos o teste não-paramétrico de Wilcoxon para amostras pareadas: 


\begin{tabular}{|c|c|c|}
\hline $\begin{array}{c}\text { Questões/Dimensões } \\
\text { comparadas }\end{array}$ & $\mathbf{Z}$ & $\mathbf{p}$ \\
\hline a3 - a3a & $-2,516$ & 0,012 \\
\hline$a 6-a 6 a$ & $-2,655$ & 0,008 \\
\hline a9 - a9a & $-0,412$ & 0,681 \\
\hline$a 12-a 12 a$ & $-0,951$ & 0,342 \\
\hline a15-a15a & $-1,153$ & 0,249 \\
\hline$a 18-a 18 a$ & $-0,551$ & 0,582 \\
\hline$m 1-m 1 a$ & $-1,414$ & 0,157 \\
\hline$m 4-m 4 a$ & -1 & 0,317 \\
\hline$m 9-m 9 a$ & $-1,857$ & 0,063 \\
\hline $\mathrm{m} 12-\mathrm{m} 12 \mathrm{a}$ & -1 & 0,317 \\
\hline $\mathrm{m} 13-\mathrm{m} 13 \mathrm{a}$ & -1 & 0,317 \\
\hline m20 - m20a & $-1,414$ & 0,157 \\
\hline $\mathrm{m} 24-\mathrm{m} 24 a$ & $-1,414$ & 0,157 \\
\hline m28 - m28a & $-1,732$ & 0,083 \\
\hline
\end{tabular}

Obtivemos diferença significativa na comparação do pré-teste com os índices identificados após o experimento nas seguintes variáveis:

- a3 (Autoeficácia para aprendizagem - item 3): $p=0,01^{*}$. Portanto, com o pós-experimento possuindo valores significativamente superiores.

- a6 (Autoeficácia para aprendizagem - item 6): $p=0,008^{*}$. Portanto, com o pós-experimento possuindo valores significativamente superiores.

Seguem estatísticas descritivas:

\begin{tabular}{|l|r|r|r|r|r|r|}
\hline $\begin{array}{c}\text { Questões/ } \\
\text { Dimensões }\end{array}$ & N & Média & $\begin{array}{c}\text { Desvio } \\
\text { Padrão }\end{array}$ & Mínimo & Máximo & Mediana \\
\hline $\mathrm{a} 3 \mathrm{a}$ & 29 & 4,03 & 1,017 & 1 & 5 & 4 \\
\hline $\mathrm{a} 6 \mathrm{a}$ & 29 & 3,59 & 1,35 & 1 & 5 & 4 \\
\hline $\mathrm{a} 9 \mathrm{a}$ & 29 & 4,1 & 0,9 & 2 & 5 & 4 \\
\hline $\mathrm{a} 12 \mathrm{a}$ & 29 & 3,72 & 1,306 & 1 & 5 & 4 \\
\hline $\mathrm{a} 15 \mathrm{a}$ & 29 & 4,21 & 0,774 & 3 & 5 & 4 \\
\hline $\mathrm{a} 18 \mathrm{a}$ & 29 & 4,1 & 0,976 & 1 & 5 & 4 \\
\hline $\mathrm{m} 1 \mathrm{a}$ & 29 & 3,76 & 1,38 & 1 & 5 & 4 \\
\hline $\mathrm{m} 4 \mathrm{a}$ & 29 & 3,48 & 1,122 & 1 & 5 & 4 \\
\hline $\mathrm{m} 9 \mathrm{a}$ & 29 & 4,07 & 1,163 & 1 & 5 & 4 \\
\hline $\mathrm{m} 12 \mathrm{a}$ & 29 & 1,97 & 1,295 & 1 & 5 & 2 \\
\hline $\mathrm{m} 13 a$ & 29 & 4,07 & 0,961 & 2 & 5 & 4 \\
\hline $\mathrm{m} 20 \mathrm{a}$ & 29 & 3,69 & 1,039 & 1 & 5 & 4 \\
\hline $\mathrm{m} 24 a$ & 29 & 4,24 & 1,185 & 0 & 5 & 5 \\
\hline $\mathrm{m} 28 \mathrm{a}$ & 29 & 3,86 & 1,329 & 0 & 5 & 4 \\
\hline
\end{tabular}




\begin{tabular}{|l|r|r|r|r|r|r|}
\hline a3 & 29 & 4,45 & 0,686 & 3 & 5 & 5 \\
\hline a6 & 29 & 4,21 & 0,774 & 2 & 5 & 4 \\
\hline a9 & 29 & 4 & 1 & 1 & 5 & 4 \\
\hline a12 & 29 & 3,45 & 1,352 & 1 & 5 & 4 \\
\hline a15 & 29 & 3,9 & 0,939 & 1 & 5 & 4 \\
\hline a18 & 29 & 3,97 & 1,052 & 1 & 5 & 4 \\
\hline $\mathrm{m} 1$ & 29 & 3,83 & 1,311 & 1 & 5 & 4 \\
\hline $\mathrm{m} 4$ & 29 & 3,52 & 1,122 & 1 & 5 & 4 \\
\hline $\mathrm{m} 9$ & 29 & 4,28 & 0,841 & 2 & 5 & 4 \\
\hline $\mathrm{m} 12$ & 29 & 2 & 1,336 & 1 & 5 & 2 \\
\hline $\mathrm{m} 13$ & 29 & 4,1 & 0,976 & 2 & 5 & 4 \\
\hline $\mathrm{m} 20$ & 29 & 3,76 & 1,091 & 1 & 5 & 4 \\
\hline $\mathrm{m} 24$ & 29 & 4,31 & 1,198 & 0 & 5 & 5 \\
\hline $\mathrm{m} 28$ & 29 & 3,97 & 1,375 & 0 & 5 & 4 \\
\hline
\end{tabular}

\section{* Grupo de Controle (GC)}

A tabela a seguir apresenta os índices alcançados nos pré-testes em comparação aos testes realizados após o contato com o material didático, para a qual também utilizamos o teste não-paramétrico de Wilcoxon para amostras pareadas:

\begin{tabular}{|l|r|r|}
\hline $\begin{array}{c}\text { Questão/Dimensões } \\
\text { comparadas }\end{array}$ & \multicolumn{1}{c|}{$\mathbf{Z}$} & \multicolumn{1}{c|}{$\mathbf{p}$} \\
\hline $\mathrm{a} 3-\mathrm{a} 3 \mathrm{a}$ & $-1,633^{\mathrm{a}}$ & 0,102 \\
\hline $\mathrm{a} 6-\mathrm{a} 6 \mathrm{a}$ & $-1,000^{\mathrm{a}}$ & 0,317 \\
\hline $\mathrm{a} 9-\mathrm{a} 9 \mathrm{a}$ &,$- 272^{\mathrm{a}}$ & 0,785 \\
\hline $\mathrm{a} 12-\mathrm{a} 12 \mathrm{a}$ & $-1,342^{\mathrm{a}}$ & 0,18 \\
\hline $\mathrm{a} 15-\mathrm{a} 15 \mathrm{a}$ & $-1,857^{\mathrm{a}}$ & 0,063 \\
\hline $\mathrm{a} 18-\mathrm{a} 18 \mathrm{a}$ & $-1,342^{\mathrm{a}}$ & 0,18 \\
\hline $\mathrm{m} 1-\mathrm{m} 1 \mathrm{a}$ &, $000^{\mathrm{b}}$ & 1 \\
\hline $\mathrm{m} 4-\mathrm{m} 4 \mathrm{a}$ & $-1,000^{\mathrm{a}}$ & 0,317 \\
\hline $\mathrm{m} 9-\mathrm{m} 9 \mathrm{a}$ &, $000^{\mathrm{b}}$ & 1 \\
\hline $\mathrm{m} 12-\mathrm{m} 12 \mathrm{a}$ &, $000^{\mathrm{b}}$ & 1 \\
\hline $\mathrm{m} 13-\mathrm{m} 13 a$ & $-1,000^{\mathrm{a}}$ & 0,317 \\
\hline $\mathrm{m} 20-\mathrm{m} 20 \mathrm{a}$ & $-1,000^{\mathrm{a}}$ & 0,317 \\
\hline $\mathrm{m} 24-\mathrm{m} 24 a$ & $-1,000^{\mathrm{a}}$ & 0,317 \\
\hline $\mathrm{m} 28-\mathrm{m} 28 \mathrm{a}$ & $-1,000^{\mathrm{a}}$ & 0,317 \\
\hline
\end{tabular}

Portanto, não foram encontradas diferenças significativas em nenhuma das variáveis comparadas.

Seguem estatísticas descritivas: 


\begin{tabular}{|l|r|r|r|r|r|r|}
\hline $\begin{array}{l}\text { Questões/ } \\
\text { Dimensões }\end{array}$ & N & Média & $\begin{array}{c}\text { Desvio } \\
\text { Padrão }\end{array}$ & Mínimo & Máximo & Mediana \\
\hline a3a & 29 & 3,48 & 1,526 & 0 & 5 & 4 \\
\hline $\mathrm{a} 6 a$ & 29 & 3,55 & 1,594 & 0 & 5 & 4 \\
\hline $\mathrm{a} 9 \mathrm{a}$ & 29 & 3,38 & 1,374 & 0 & 5 & 4 \\
\hline $\mathrm{a} 12 \mathrm{a}$ & 29 & 2,76 & 1,596 & 0 & 5 & 3 \\
\hline $\mathrm{a} 15 \mathrm{a}$ & 29 & 3,07 & 1,534 & 0 & 5 & 4 \\
\hline $\mathrm{a} 18 \mathrm{a}$ & 29 & 3,59 & 1,35 & 0 & 5 & 4 \\
\hline $\mathrm{m} 1 \mathrm{a}$ & 29 & 3,48 & 1,43 & 0 & 5 & 4 \\
\hline $\mathrm{m} 4 \mathrm{a}$ & 29 & 3,48 & 1,09 & 0 & 5 & 3 \\
\hline $\mathrm{m} 9 \mathrm{a}$ & 29 & 3,62 & 1,635 & 0 & 5 & 4 \\
\hline $\mathrm{m} 12 \mathrm{a}$ & 29 & 2,24 & 1,64 & 0 & 5 & 1 \\
\hline $\mathrm{m} 13 \mathrm{a}$ & 29 & 3,79 & 1,292 & 0 & 5 & 4 \\
\hline $\mathrm{m} 20 \mathrm{a}$ & 29 & 2,86 & 1,217 & 0 & 5 & 3 \\
\hline $\mathrm{m} 24 \mathrm{a}$ & 29 & 4,03 & 1,349 & 0 & 5 & 5 \\
\hline $\mathrm{m} 28 \mathrm{a}$ & 29 & 3,97 & 1,375 & 0 & 5 & 5 \\
\hline $\mathrm{a} 3$ & 29 & 3,97 & 0,981 & 2 & 5 & 4 \\
\hline $\mathrm{a} 6$ & 29 & 3,59 & 1,547 & 0 & 5 & 4 \\
\hline $\mathrm{a} 9$ & 29 & 3,41 & 1,402 & 0 & 5 & 4 \\
\hline $\mathrm{a} 12$ & 29 & 2,9 & 1,611 & 0 & 5 & 3 \\
\hline $\mathrm{a} 15$ & 29 & 3,41 & 1,296 & 0 & 5 & 4 \\
\hline $\mathrm{a} 18$ & 29 & 3,79 & 1,177 & 0 & 5 & 4 \\
\hline $\mathrm{m} 1$ & 29 & 3,48 & 1,43 & 0 & 5 & 4 \\
\hline $\mathrm{m} 4$ & 29 & 3,59 & 0,867 & 2 & 5 & 3 \\
\hline $\mathrm{m} 9$ & 29 & 3,62 & 1,635 & 0 & 5 & 4 \\
\hline $\mathrm{m} 12$ & 29 & 2,24 & 1,64 & 0 & 5 & 1 \\
\hline $\mathrm{m} 13$ & 29 & 3,9 & 1,081 & 0 & 5 & 4 \\
\hline $\mathrm{m} 20$ & 29 & 2,97 & 1,085 & 1 & 5 & 3 \\
\hline $\mathrm{m} 24$ & 29 & 4,17 & 1,104 & 2 & 5 & 5 \\
\hline $\mathrm{m} 28$ & 29 & 4,14 & 1,156 & 1 & 5 & 5 \\
\hline
\end{tabular}

\subsection{3 - Experimento 1: Pós-teste}

Ambos os grupos (GE e GC) responderam a uma questão aberta, na qual puderam tratar aberta e sinceramente sobre o material didático ao qual tiveram acesso.

No GE, a questão proposta foi a seguinte: "o que você pensa sobre a possibilidade de ler e/ou ouvir os conteúdos?"

Dentre os alunos que se posicionaram, a grande maioria demonstrou abertamente e pelos mais variados motivos que "gostaram" da possibilidade de escolher entre a leitura e/ou a audição, conforme segue: 
- Alunos que gostaram por motivos pessoais (por diversas razões aprovaram ter opções para escolha, dentre elas pelo fato de otimizar o tempo ou permitir estudar enquanto fazem outras atividades cotidianas): quinze alunos (cerca de 51,7\%), conforme alguns comentários: "ouvindo é mais fácil estudar, a gente ia conseguir conciliar mais fácil com outras atividades" ou "é bom escolher, cada um vai no que é melhor para si", "eu gosto mais de ouvir do que de ler, dá mais vontade de estudar".

- Alunos que gostaram por motivos ligados à aprendizagem (melhoria e facilitação da memorização e compreensão dos conteúdos): onze alunos (cerca de $37,9 \%$ ), conforme alguns comentários: "eu prefiro ouvir, entendo melhor" ou "eu gravei e entendi melhor porque pude ler e ouvir o texto".

- Não gostaram da opção de audição: um aluno (cerca de 3,4\%), conforme comentário: "eu gosto de ler, acho que todos deveriam ler".

- Não responderam: dois alunos (cerca de 6,8\%).

Já no GC foi realizado o seguinte questionamento: "o que você pensa sobre o material em texto escrito (apostila)?" Neste caso, a proposta era apenas de verificar se os alunos gostam do texto escrito (apostila) como opção de material didático, uma vez que os participantes do GC não sabiam que o GE estava tendo acesso ao material com implementações diferenciadas das habituais (audição do texto). Nesse contexto, os alunos se posicionaram da seguinte maneira:

- Aprovam o texto escrito: dezesseis alunos (cerca de 55,2\%), como seguem alguns comentários: "já estou acostumada a estudar com livros ou apostila" ou "a apostila é fácil de levar para diferentes lugares e estudar".

- Acreditam espontaneamente que poderiam ter outras opções para complementar o texto escrito: dez alunos (cerca de 34,5\%). "Acho que só o texto é maçante para estudar, acho que precisamos de videoaulas também ou outras opções".

- Não responderam ao questionamento: três alunos (cerca de 10,3\%). 


\subsection{4 - Experimento 1: Análise Geral dos Resultados}

Partindo dos resultados obtidos no pré-teste, no teste e no pós-teste, percebeu-se que oferecer opções para escolha da leitura ou audição do texto pode ser uma estratégia interessante para o processo de aprendizagem, dadas algumas observações relevantes.

A maioria dos alunos $(51,7 \%)$ preferiram ouvir o textonarrado por uma voz feminina, apontando-a como uma estratégia preferencialmente recomendada para disponibilização de textos aos discentes. Contudo, seguindo os pressupostos do DU para a Aprendizagem de tornar o material autoadaptável, os demais alunos também puderam optar por outras estratégias (audição na voz masculina, leitura do texto, ou mais de uma estratégia de forma não-simultânea) que the pareceram mais agradáveis; o que, embora não tenha alterado os índices de Motivação, foi importante para o aumento geral dos níveis de Autoeficácia para a Aprendizagem em relação ao GC que utilizou apenas a leitura em tela do texto. Isso ficou ainda mais evidenciado ao comparar com os resultados dos pré-testes, nos quais o GC não demonstrou alterações em nenhuma das dimensões, enquanto o GE apontou, níveis significativamente maiores de Autoeficácia para a Aprendizagem.

Ressalta-se o fato de o material didático na versão áudio atender a um princípio do DU para a Aprendizagem e permitir maior acessibilidade por facilitar o acesso para pessoas com diferentes preferências, habilidades de de pessoas com deficiência visual.

Finalmente, o pós-teste ratificou que além de atender a um dos princípios do DU para a Aprendizagem e aumentar o acesso a informações pela utilização de diferentes canais sensoriais, é importante oferecernão apenas o texto para a leitura, mas também o áudio-texto (preferencialmente na voz feminina, mas se possível também com a opção da voz masculina) e disponibilizar as diferentes opções para acesso e escolha do discente. Corrobora com esta ideia, o fato de a maioria dos participantes do GE relatar que a escolha entre o texto para leitura ou para audição, tanto por motivos ligados à aprendizagem quanto por motivos pessoais, trata-se de uma estratégia que contribui e/ou facilita para a aprendizagem. 
Os resultados obtidos se assemelham aos de outros trabalhos, nos quais o material em áudio também era utilizado e apreciado pela maioria dos integrantes da amostra e recomendado como vantajoso para o processo de aprendizagem e/ou ainda como forma de tornar o material acessível a discentes com diferentes necessidades/habilidades/preferências (MOSCATI et al., 2012; CARVALHO et al., 2012; MELO et al., 2012; GOMES et al., 2012; RAMPELOTTO et al., 2012; MOUSAVI; LOW; SWELLER, 1995; TINDALLFORD; CHANDLER; SWELLER, 1997).

Salienta-se, finalmente, que as alterações dos níveis de Autoeficácia para a Aprendizagem podem evidenciar que um material capaz de se adaptar as preferências e/ou necessidades, no que se refere àopção de leitura e audição do texto, trata-se de uma forma viável de ampliar as possibilidades de sucesso no processo de ensino-aprendizagem, uma vez que a Autoeficácia para a Aprendizagem assume um papel relevante na explicação da realização dos discentes, nomeadamente no que se refere à escolha do tipo de tarefa a realizar, aos níveis de investimento nessas tarefas, à persistência perante adversidades e, consequentemente, aos resultados acadêmicos (PAJARES, 2002; PINA NEVES; FARIA, 2007; SÁ, 2007).

8.2 - Proposta Didática 2 Inspirada no Princípio I do DU para a Aprendizagem (PD2_DU1) -Escolha entre Videoaula Convencional (Recursos Audiovisuais) ou Videoaula com Legenda Parcialmente Ambientada

\subsection{1- Experimento 2: Comparação entre os GE e GC}

A tabela a seguirapresenta as escolhas dos discente-participantes do GE para acesso aos conteúdos:

\begin{tabular}{|c|l|c|c|}
\hline $\begin{array}{c}\text { ESTRATÉGIAS ESCOLHIDAS PELOS } \\
\text { DISCENTES-PARTICIPANTES - GE }\end{array}$ & \multirow{2}{*}{$\mathbf{n}$} & \multirow{2}{*}{ DESCRIÇÃO } \\
\cline { 1 - 2 } C & \multicolumn{1}{|c|}{} & \\
\hline 1 & Vídeo com áudio & 13 & 50 \\
\hline 2 & Vídeo com legenda & 13 & 50 \\
\hline 3 & Vídeo com áudio + Vídeo com legenda & 0 & 0 \\
\hline
\end{tabular}

Seguem resultados obtidos a partir da comparação entre o GE e o GC. Inicialmente testamos se as variáveis possuem ou não distribuição Normal através do teste de Kolmogorov-Smirnov: 


\begin{tabular}{|l|r|r|}
\hline \multicolumn{3}{|c|}{ GE } \\
\hline Dimensões & $\begin{array}{c}\text { Kolmogorov- } \\
\text { Smirnov Z }\end{array}$ & \multicolumn{1}{c|}{$\mathbf{p}$} \\
\hline AUTOEFICÁCIA &, 569 &, 903 \\
\hline MECE & 1,190 &, 118 \\
\hline MEINTRO &, 913 &, 375 \\
\hline MEIDEN & 1,566 &, 015 \\
\hline MIVE &, 836 &, 487 \\
\hline MIR &, 906 &, 385 \\
\hline MIS &, 735 &, 652 \\
\hline DES & 1,310 &, 064 \\
\hline
\end{tabular}

\begin{tabular}{|l|r|r|}
\hline \multicolumn{3}{|c|}{ GC } \\
\hline \multicolumn{1}{|c|}{ Dimensões } & $\begin{array}{r}\text { Kolmogorov- } \\
\text { Smirnov Z }\end{array}$ & \multicolumn{1}{c|}{$\mathbf{p}$} \\
\hline AUTOEFICÁCIA &, 824 &, 506 \\
\hline MECE & 1,202 &, 111 \\
\hline MEINTRO &, 829 &, 497 \\
\hline MEIDEN & 1,118 &, 164 \\
\hline MIVE &, 793 &, 556 \\
\hline MIR &, 854 &, 459 \\
\hline MIS &, 880 &, 421 \\
DES & 2,119 &, 000 \\
\hline
\end{tabular}

Partindo dos resultados obtidos, rejeitamos a normalidade das variáveis MEIDEN, no GE e DES, no GC, para as quais utilizamos o teste nãoparamétrico de Mann-Whitney. Nas demais, aplicamos o teste de t de Student para amostras independentes.

- AUTOEFICÁCIA: $t=2,02 \quad p=0,05^{*}$

Há diferença significativa: O GE possui valores significativamente superiores.

- MECE: $t=1,53 \quad p=0,14$

Não há diferença significativa.

- MEINTRO: $t=2,63 \quad p=0,001^{*}$

Há diferença significativa, O GE possui valores significativamente superiores.

- MEIDEN: $Z=1,51 \quad p=0,13$

Não há diferença significativa.

- MIVE: $t=2,54 p=0,01^{*}$ 
Há diferença significativa: o GE possui valores significativamente superiores.

- MIR: $t=2,60 p=0,01^{*}$

Há diferença significativa: o GE possui valores significativamente superiores.

- MIS: $t=2,17 p=0,04^{*}$

- Há diferença significativa: o GE possui valores significativamente superiores.

- DES: $Z=1,95 \quad p=0,05^{*}$

- Há diferença significativa: o GC possui valores significativamente superiores.

Intervalos de confiança de 95\% para as diferenças de médias:

\begin{tabular}{|l|r|r|}
\hline \multicolumn{3}{|c|}{ IndependentSamples Test } \\
\hline \multicolumn{3}{|c|}{ t-test for Equality of Means } \\
\hline 95\% Confidence Interval of the Difference \\
\hline Dimensões & \multicolumn{1}{|c|}{ Lower } & \multicolumn{1}{c|}{ Upper } \\
\hline AUTOEFICÁCIA & 0,0007 & 0,92238 \\
\hline MECE & $-0,18025$ & 1,29563 \\
\hline MEINTRO & 0,15691 & 1,20848 \\
\hline MEIDEN & $-0,01293$ & 1,14754 \\
\hline MIVE & 0,15287 & 1,3279 \\
\hline MIR & 0,16388 & 1,29766 \\
\hline MIS & 0,04483 & 1,24363 \\
\hline DES & $-0,20964$ & 0,9981 \\
\hline
\end{tabular}

Seguem, para finalizar, as estatísticas descritivas:

\begin{tabular}{|c|c|c|c|c|c|c|c|c|c|}
\hline \multicolumn{2}{|c|}{ GRUPO } & AUTOEFICÁCIA & MECE & MEINTRO & MEIDEN & MIVE & MIR & MIS & DES \\
\hline \multirow{5}{*}{ Experimental } & Median & 4,0000 & 4,6250 & 4,5000 & 5,0000 & 3,8750 & 4,1250 & 4,2500 & 1,2500 \\
\hline & Minimum & 2,60 & 1,25 & 2,75 & 2,50 & 1,25 & 2,00 & 2,00 & 1,00 \\
\hline & Maximum & 5,00 & 5,00 & 5,00 & 5,00 & 5,00 & 5,00 & 5,00 & 4,75 \\
\hline & Mean & 3,9481 & 4,1538 & 4,3846 & 4,4808 & 3,6154 & 4,0769 & 4,0192 & 1,9423 \\
\hline & $\begin{array}{l}\text { Std. } \\
\text { Deviation }\end{array}$ & ,59758 & ,95676 & ,63730 & ,70683 & ,90893 & ,82392 & ,86001 & 1,21924 \\
\hline \multirow{5}{*}{ Controle } & Median & 3,7500 & 4,3750 & 3,8750 & 4,3750 & 3,0000 & 3,6250 & 3,6250 & 1,0000 \\
\hline & Minimum & 1,30 & ,25 & 1,25 & ,75 & ,75 & 1,00 & 1,50 & 1,00 \\
\hline & Maximum & 4,90 & 5,00 & 5,00 & 5,00 & 4,50 & 5,00 & 5,00 & 4,25 \\
\hline & Mean & 3,4865 & 3,5962 & 3,7019 & 3,9135 & 2,8750 & 3,3462 & 3,3750 & 1,5481 \\
\hline & $\begin{array}{l}\text { Std. } \\
\text { Deviation }\end{array}$ & ,99825 & $1,59856 \mathrm{E} 0$ & 1,16194 & 1,28051 & 1,17951 & 1,17490 & 1,24950 & ,92471 \\
\hline \multirow{5}{*}{ Total } & Median & 3,8500 & 4,5000 & 4,2500 & 4,6250 & 3,5000 & 4,0000 & 4,0000 & 1,0000 \\
\hline & Minimum & 1,30 &, 25 & 1,25 & ,75 & ,75 & 1,00 & 1,50 & 1,00 \\
\hline & Maximum & 5,00 & 5,00 & 5,00 & 5,00 & 5,00 & 5,00 & 5,00 & 4,75 \\
\hline & Mean & 3,7173 & 3,8750 & 4,0433 & 4,1971 & 3,2452 & 3,7115 & 3,6971 & 1,7452 \\
\hline & $\begin{array}{l}\text { Std. } \\
\text { Deviation }\end{array}$ & ,84725 & $1,33441 \mathrm{E} 0$ & ,98980 & 1,06336 & 1,10756 & 1,07030 & 1,11071 & 1,08971 \\
\hline
\end{tabular}




\subsection{2- Experimento 2: Comparação dos Índices Identificados no Pré-Teste e os Alcançados após o Contato com o Material Didático}

\section{* Grupo Experimental (GE)}

A tabela a seguir apresenta os índices alcançados nos pré-testes em comparação aos testes realizados após o contato com o material didático, para a qual utilizamos o teste não-paramétrico de Wilcoxon para amostras pareadas:

\begin{tabular}{|l|r|r|}
\hline $\begin{array}{c}\text { Questão/Dimensões } \\
\text { Comparadas }\end{array}$ & $\mathbf{z}$ & $\mathbf{p}$ \\
\hline $\mathrm{a} 3-\mathrm{a} a$ & $-2,714$ &, 007 \\
\hline $\mathrm{a} 6-\mathrm{a} a \mathrm{a}$ & $-1,414^{\mathrm{a}}$ &, 157 \\
\hline $\mathrm{a} 9-\mathrm{a} 9 \mathrm{a}$ & $-3,162$ &, 002 \\
\hline $\mathrm{a} 12-\mathrm{a} 12 \mathrm{a}$ & $-2,449$ &, 014 \\
\hline $\mathrm{a} 15-\mathrm{a} 15 \mathrm{a}$ & $-1,342^{\mathrm{a}}$ &, 180 \\
\hline $\mathrm{a} 18-\mathrm{a} 18 \mathrm{a}$ & $-1,633^{\mathrm{a}}$ &, 102 \\
\hline $\mathrm{m} 1-\mathrm{m} 1 \mathrm{a}$ & $-2,271$ &, 023 \\
\hline $\mathrm{m} 4-\mathrm{m} 4 \mathrm{a}$ & $-1,000^{\mathrm{a}}$ &, 317 \\
\hline $\mathrm{m} 9-\mathrm{m} 9 \mathrm{a}$ & $-2,121$ &, 034 \\
\hline $\mathrm{m} 12-\mathrm{m} 12 \mathrm{a}$ & $-1,414^{\mathrm{a}}$ &, 157 \\
\hline $\mathrm{m} 13-\mathrm{m} 13 \mathrm{a}$ & $-1,414^{\mathrm{a}}$ &, 157 \\
\hline $\mathrm{m} 20-\mathrm{m} 20 \mathrm{a}$ & $-1,000^{\mathrm{a}}$ &, 317 \\
\hline $\mathrm{m} 24-\mathrm{m} 24 a$ & $-2,828$ &, 005 \\
\hline $\mathrm{m} 28-\mathrm{m} 28 \mathrm{a}$ & $-1,414^{\mathrm{a}}$ &, 157 \\
\hline
\end{tabular}

Portanto, há diferença significativa nas variáveis:

- a3 (Autoeficácia para a Aprendizagem - item 3): $p=0,007^{\star}$. Portanto, com o pós apresentando valores significativamente superiores aos do pré-experimentos.

- a9 (Autoeficácia para a Aprendizagem - item 9): $p=0,002^{*}$. Portanto, com o pós apresentando valores significativamente superiores aos do pré-experimento.

- a12 (Autoeficácia para a Aprendizagem - item 12): $p=0,01^{*}$. Portanto, com o pós apresentando valores significativamente superiores aos do pré-experimento. 
- m1 (Motivação Extrínseca - Controle Externo - Questão 1): $p=0,02^{*}$. Portanto, com o pós apresentando valores significativamente superiores aos do pré-experimento.

- m9 (Motivação Extrínseca - Introjeção - Questão 9): $p=0,03^{*}$. Portanto, com o pós apresentando valores significativamente superiores aos do pré-experimento.

Seguem estatísticas descritivas:

\begin{tabular}{|c|c|c|c|c|c|c|}
\hline $\begin{array}{l}\text { Questões/ } \\
\text { Dimensões }\end{array}$ & $\mathbf{N}$ & Média & $\begin{array}{l}\text { Desvio } \\
\text { padrão }\end{array}$ & Mínimo & Máximo & Mediana \\
\hline a3a & 26 & 4,04 & ,999 & 1 & 5 & 4,00 \\
\hline a6a & 26 & 3,96 & 1,038 & 1 & 5 & 4,00 \\
\hline$a 9 a$ & 26 & 3,31 & 1,087 & 1 & 5 & 3,50 \\
\hline a12a & 26 & 3,50 & 1,273 & 1 & 5 & 4,00 \\
\hline a15a & 26 & 4,00 & ,800 & 2 & 5 & 4,00 \\
\hline a18a & 26 & 3,88 & , 816 & 2 & 5 & 4,00 \\
\hline $\mathrm{m} 1 \mathrm{a}$ & 26 & 3,46 & 1,240 & 1 & 5 & 3,00 \\
\hline $\mathrm{m} 4 \mathrm{a}$ & 26 & 3,46 & ,989 & 1 & 5 & 3,00 \\
\hline $\mathrm{m} 9 \mathrm{a}$ & 26 & 4,08 & 744 & 2 & 5 & 4,00 \\
\hline $\mathrm{m} 12 \mathrm{a}$ & 26 & 2,15 & 1,190 & 1 & 4 & 2,00 \\
\hline $\mathrm{m} 13 \mathrm{a}$ & 26 & 4,08 & ,744 & 3 & 5 & 4,00 \\
\hline $\mathrm{m} 20 \mathrm{a}$ & 26 & 3,58 & 1,102 & 1 & 5 & 4,00 \\
\hline $\mathrm{m} 24 \mathrm{a}$ & 26 & 4,23 & ,710 & 3 & 5 & 4,00 \\
\hline $\mathrm{m} 28 \mathrm{a}$ & 26 & 4,31 & 788 & 2 & 5 & 4,00 \\
\hline a3 & 26 & 4,38 & ,752 & 2 & 5 & 4,50 \\
\hline a6 & 26 & 4,04 & 1,038 & 1 & 5 & 4,00 \\
\hline a9 & 26 & 3,69 & 1,087 & 2 & 5 & 4,00 \\
\hline a12 & 26 & 3,73 & 1,041 & 2 & 5 & 4,00 \\
\hline a15 & 26 & 4,12 & 653 & 3 & 5 & 4,00 \\
\hline a18 & 26 & 4,04 & 662 & 2 & 5 & 4,00 \\
\hline $\mathrm{m} 1$ & 26 & 3,77 & 1,142 & 1 & 5 & 4,00 \\
\hline m4 & 26 & 3,50 & 949 & 1 & 5 & 3,00 \\
\hline $\mathrm{m} 9$ & 26 & 4,31 & 618 & 3 & 5 & 4,00 \\
\hline m12 & 26 & 2,23 & 1,243 & 1 & 5 & 2,00 \\
\hline $\mathrm{m} 13$ & 26 & 4,15 & ,784 & 3 & 5 & 4,00 \\
\hline $\mathrm{m} 20$ & 26 & 3,62 & 1,061 & 1 & 5 & 4,00 \\
\hline m24 & 26 & 4,54 & (706 & 3 & 5 & 5,00 \\
\hline $\mathrm{m} 28$ & 26 & 4,38 & ,804 & 2 & 5 & 5,00 \\
\hline
\end{tabular}


A tabela a seguir apresenta os índices alcançados nos pré-testes em comparação aos testes realizados após o contato com o material didático, para a qual utilizamos o teste não-paramétrico de Wilcoxon para amostras pareadas:

\begin{tabular}{|l|r|r|}
\hline $\begin{array}{c}\text { Questão/Dimensões } \\
\text { comparadas }\end{array}$ & $\mathbf{z}$ & $\mathbf{p}$ \\
\hline $\mathrm{a} 3-\mathrm{a} 3 \mathrm{a}$ & $-1,000^{\mathrm{a}}$ &, 317 \\
\hline $\mathrm{a} 6-\mathrm{a} \mathrm{a} a$ & $-1,342^{\mathrm{a}}$ &, 180 \\
\hline $\mathrm{a} 9-\mathrm{a} 9 \mathrm{a}$ & $-1,000^{\mathrm{a}}$ &, 317 \\
\hline $\mathrm{a} 12-\mathrm{a} 12 \mathrm{a}$ & $-1,000^{\mathrm{a}}$ &, 317 \\
\hline $\mathrm{a} 15-\mathrm{a} 15 \mathrm{a}$ & $-1,000^{\mathrm{a}}$ &, 317 \\
\hline $\mathrm{a} 18-\mathrm{a} 18 \mathrm{a}$ & $-1,000^{\mathrm{a}}$ &, 317 \\
$\mathrm{~m} 1-\mathrm{m} 1 \mathrm{a}$ & $-1,000^{\mathrm{a}}$ &, 317 \\
\hline $\mathrm{m} 4-\mathrm{m} 4 \mathrm{a}$ & $-1,000^{\mathrm{a}}$ &, 317 \\
\hline $\mathrm{m} 9-\mathrm{m} 9 \mathrm{a}$ & $-1,000^{\mathrm{a}}$ &, 317 \\
\hline $\mathrm{m} 12-\mathrm{m} 12 \mathrm{a}$ & $-1,342^{\mathrm{b}}$ &, 180 \\
\hline $\mathrm{m} 13-\mathrm{m} 13 \mathrm{a}$ &,$- 966^{\mathrm{a}}$ &, 334 \\
\hline $\mathrm{m} 20-\mathrm{m} 20 \mathrm{a}$ & $-1,000^{\mathrm{a}}$ &, 317 \\
\hline $\mathrm{m} 24-\mathrm{m} 24 a$ & $-1,000^{\mathrm{a}}$ &, 317 \\
\hline $\mathrm{m} 28-\mathrm{m} 28 \mathrm{a}$ & $-1,342^{\mathrm{a}}$ &, 180 \\
\hline
\end{tabular}

Portanto, não encontramos diferenças significativas.

Seguem as estatísticas descritivas:

\begin{tabular}{|l|r|r|r|r|r|r|}
\hline $\begin{array}{l}\text { Questões/ } \\
\text { Dimensões }\end{array}$ & N & Média & $\begin{array}{r}\text { Desvio } \\
\text { Padrão }\end{array}$ & Mínimo & Máximo & Mediana \\
\hline $\mathrm{a} 3 \mathrm{a}$ & 26 & 3,12 & 1,505 & 0 & 5 & 3,50 \\
\hline $\mathrm{a} 6 \mathrm{a}$ & 26 & 3,65 & 1,355 & 0 & 5 & 4,00 \\
\hline $\mathrm{a} 9 \mathrm{a}$ & 26 & 3,38 & 1,098 & 0 & 5 & 3,50 \\
\hline $\mathrm{a} 12 \mathrm{a}$ & 26 & 2,96 & 1,248 & 0 & 5 & 3,00 \\
\hline $\mathrm{a} 15 \mathrm{a}$ & 26 & 3,54 & 1,303 & 0 & 5 & 4,00 \\
\hline $\mathrm{a} 18 \mathrm{a}$ & 26 & 3,46 & 1,421 & 0 & 5 & 4,00 \\
\hline $\mathrm{m} 1 \mathrm{a}$ & 26 & 3,42 & 1,604 & 0 & 5 & 4,00 \\
\hline $\mathrm{m} 4 \mathrm{a}$ & 26 & 3,19 & 1,167 & 0 & 5 & 3,00 \\
\hline $\mathrm{m} 9 \mathrm{a}$ & 26 & 3,81 & 1,386 & 0 & 5 & 4,00 \\
\hline $\mathrm{m} 12 \mathrm{a}$ & 26 & 1,85 & 1,223 & 1 & 5 & 1,00 \\
\hline $\mathrm{m} 13 \mathrm{a}$ & 26 & 3,35 & 1,495 & 0 & 5 & 4,00 \\
\hline $\mathrm{m} 20 \mathrm{a}$ & 26 & 2,96 & 1,280 & 0 & 5 & 3,00 \\
\hline $\mathrm{m} 24 \mathrm{a}$ & 26 & 3,81 & 1,575 & 0 & 5 & 4,00 \\
\hline $\mathrm{m} 28 \mathrm{a}$ & 26 & 3,27 & 1,801 & 0 & 5 & 4,00 \\
\hline $\mathrm{a} 3$ & 26 & 3,31 & 1,408 & 0 & 5 & 4,00 \\
\hline $\mathrm{a} 6$ & 26 & 3,85 & 1,120 & 1 & 5 & 4,00 \\
\hline $\mathrm{a} 9$ & 26 & 3,42 & 1,102 & 0 & 5 & 4,00 \\
\hline $\mathrm{a} 12$ & 26 & 3,00 & 1,296 & 0 & 5 & 3,00 \\
\hline $\mathrm{a} 15$ & 26 & 3,58 & 1,270 & 0 & 5 & 4,00 \\
\hline
\end{tabular}




\begin{tabular}{|l|r|r|r|r|r|r|}
\hline $\mathrm{a} 18$ & 26 & 3,62 & 1,235 & 0 & 5 & 4,00 \\
\hline $\mathrm{m} 1$ & 26 & 3,46 & 1,630 & 0 & 5 & 4,00 \\
\hline $\mathrm{m} 4$ & 26 & 3,23 & 1,177 & 0 & 5 & 3,00 \\
\hline $\mathrm{m} 9$ & 26 & 3,85 & 1,405 & 0 & 5 & 4,00 \\
\hline $\mathrm{m} 12$ & 26 & 1,73 & 1,218 & 1 & 5 & 1,00 \\
\hline $\mathrm{m} 13$ & 26 & 3,58 & 1,137 & 1 & 5 & 4,00 \\
\hline $\mathrm{m} 20$ & 26 & 3,00 & 1,296 & 0 & 5 & 3,00 \\
\hline $\mathrm{m} 24$ & 26 & 3,85 & 1,592 & 0 & 5 & 4,00 \\
\hline $\mathrm{m} 28$ & 26 & 3,42 & 1,677 & 0 & 5 & 4,00 \\
\hline
\end{tabular}

\subsection{3 -Experimento 2: Pós-teste}

Ambos os grupos responderam a uma questão aberta, na qual puderam tratar aberta e sinceramente sobre o material ao qual tiveram acesso.

No GE, a questão proposta foi a seguinte: "o que você pensa sobre a inserção da legenda como uma opção para expectação da videoula?"

Dentre os alunos que se posicionaram, a grande maioria demonstrou abertamente e pelos mais variados motivos que "gostaram" da possibilidade de optar pela expectação da videoaula convencional ou com legenda (algumas características de legenda ambientada), conforme segue:

- Alunos que gostaram por motivos pessoais (por ter a oportunidade de escolha, por preferir a leitura ou por oferecer acesso a pessoas que não podem ouvir): quatorze alunos (cerca de 53,8\%), conforme alguns comentários: "eu entendo melhor quando leio, legal!" ou "é interessante porque assim cada um estuda como prefere".

- Alunos que gostaram por motivos ligados à aprendizagem (melhoria da performance da aprendizagem e facilitação da compreensão dos conteúdos): sete alunos (cerca de 26,9\%), conforme alguns comentários: "Interessante, pois fica mais fácil a compressão" ou "Legal, eu gostei das duas formas, fica mais fácil entender o conteúdo".

- Ficaram indiferentes: um aluno (cerca de 3,8\%), conforme comentário: "para mim, tanto faz, preferi normal".

- Não gostaram da opção de legenda: um aluno (cerca de aproximadamente 3,8\%). Segue comentário: "não gostei do vídeo com legenda, por isso escolhi o normal”.

- Não responderam: três alunos (cerca de 11,5\%). 
Já no GC foi realizado o seguinte questionamento: "o que você pensa sobre a videoaula?" Neste caso, a proposta era apenas de verificar se os alunos gostam da videoaula como opção de material didático, uma vez que o GC não sabia que o GE estava tendo acesso ao material com implementações diferenciadas das habituais (videoaula com legenda parcialmente ambientada). A questão foi respondida por vinte alunos (cerca de $76,9 \%$ ) que relataram gostar da videoaula como opção de material didático mais fácil de ser compreendido em relação aos demais materiais, como seguem alguns comentários: "A videoaula é uma forma muito interessante de aprender melhor determinado conteúdo" ou "acho a videoaula uma boa sugestão. Com essa videoaula que acabei de assistir pude compreender ate melhor sobre 0 assunto". Os demais alunos (seis alunos - cerca de 23,1\%) não responderam ao questionamento.

\subsection{4 -Experimento 2: Análise Geral dos Resultados}

Partindo dos resultados obtidos no pré-teste, no teste e no pós-teste, percebeu-se que oferecer opções para escolha da expectação da videoaula comum (audiovisual) ou com legenda pode ser uma estratégia interessante para o processo de aprendizagem, dadas algumas observações importantes.

Os alunos se dividiram igualmente ao escolher a forma de expectação do vídeo, demonstrando evidências de que, assim como a videoaula com recursos audiovisuais, a videoaula com legenda parcialmente ambientada pode ser uma opção igualmente relevante para disponibilização aos discentes.

Seguindo os pressupostos do DU para a Aprendizagem, tornando o material autoadaptável, os alunos puderam escolher (de forma não simultânea) pelas opções que the pareceram mais agradáveis (vídeo com audiovisual ou com legenda - sem áudio), o que foi importante para o aumento no GE em relação ao GC, dos níveis de Autoeficácia para a Aprendizagem e de Motivação no que se refere às variáveis Motivação extrínseca por introjeção, Motivação intrínseca para vivenciar estímulo, Motivação intrínseca para realização e Motivação intrínseca para saber.

Salienta-se que o aumento dos níveis de Autoeficácia para a Aprendizagem é constructo muito importante, uma vez que discentes com crenças positivas de Autoeficácia para a Aprendizagem se utilizam de mais 
estratégias cognitivas e metacognitivas, além de persistirem nas atividades por mais tempo do que aqueles com baixo senso (PAJARES, 1996).

Além disso, os índices maiores de Motivação extrínseca por introjeção, Motivação intrínseca para vivenciar estímulo, Motivação intrínseca para realização e Motivação intrínseca para saber apontam que os alunos do GEexerceram autopressão interna para realizar a expectação do vídeo, ao passo que buscaram experimentar sensações estimulantes (neste caso específico de natureza sensorial) e fizeram a expectação pela satisfação que decorre da busca de realização e do aprendizado (SOBRAL, 2003).

Isso ficou ainda mais claro após a comparação entre o pré-teste e o teste, no qualos indivíduos do GE apresentaram índices mais positivos de Autoeficácia para a Aprendizagem (em mais de um de seus itens comparados) e de Motivação extrínseca por controle externo e por introjeção. Portanto, os alunos, após o contato com a proposta didática em questão, além de se sentirem mais capazes de realizar com sucesso a atividade proposta, demonstraram recursos motivacionais para responderem aos apelos externos e aos mecanismos internos para expectação da videoaula.

Outra questão importante a ser relatadatrata-se do fato de a videoaula com legenda atender a um princípio do DU para a Aprendizagem e permitir maior acessibilidade para pessoas com preferências e necessidades distintas, além das pessoas com deficiência auditiva. Nesse contexto, reconhece-se a importância do uso da Libras (Língua Brasileira de Sinais) como primeira opção para alunos com deficiência auditiva (SALERMO, 2012). Entretanto, embora não faça parte do espoco deste trabalho, recomenda-se a implementação em materiais, além da legenda ambientada, da legenda com Libras para opções adequadas de acessibilidade.

Finalmente, o pós-teste ratificou que além de atender a um dos princípios do DU para a Aprendizagem e aumentar o acesso a informações pela utilização de diferentes canais sensoriais, a disponibilização da videoaula com recursos audiovisuais e/ou com legenda (realizada com determinadas características de legenda ambientada) para acesso e escolha do discente pode ser apontada como uma estratégia viável para inserção em cursos superiores. Isso foi ratificado quando a maioria dos participantes do GE $(80,7 \%)$ relatouque, tanto por motivos pessoais como por motivos ligados à 
aprendizagem, gostaram e se sentiram mais predispostos a persistir no processo de aprendizagem, utilizando-se do recurso didático disponibilizado.

Os resultados obtidos se assemelham aos de outros trabalhos, nos quais a videoaula com legenda também era utilizada e apreciada, além de recomendada como vantajosa para o processo de aprendizagem e/ou ainda como forma de tornar o material acessível a discentes com diferentes necessidades/habilidades/preferências (SPANOS; SMITH, 2003; SOUSA, 2005; VERAS FILHO, 2007; CUNHA, 2007; HARVEY, 2009; GOMES, 2010; DUARTE et al., 2012; OLIVEIRA et al., 2012).

8.3 - Proposta Didática 3 Inspirada no Princípio I do DU para a Aprendizagem (PD3_DU1) - Escolha entre Videoaula Convencional ou Videoaula com Controle de Velocidade

\subsection{1-Experimento 3: Comparação entre os GE e o GC}

A tabela a seguirapresenta as escolhas dos discentes-participantes do GE para acesso aos conteúdos:

\begin{tabular}{|c|c|c|c|}
\hline \multicolumn{2}{|r|}{$\begin{array}{c}\text { ESTRATÉGIAS ESCOLHIDAS PELOS DISCENTES- } \\
\text { PARTICIPANTES - GE }\end{array}$} & \multirow[t]{2}{*}{$\mathbf{n}$} & \multirow[t]{2}{*}{$\%$} \\
\hline $\mathbf{C}$ & DESCRIÇÃO & & \\
\hline$\overline{1}$ & Expectação da videoaula com velocidade mais rápida & 7 & 23,3 \\
\hline 2 & Expectação da videoaula com velocidade mais lenta & 4 & 13,3 \\
\hline 3 & $\begin{array}{l}\text { Expectação da videoaula com velocidade padrão } \\
\text { (convencional) }\end{array}$ & 3 & 63,3 \\
\hline
\end{tabular}

São apresentadas a seguiras tabelas comparativas entre os GE e GC. Inicialmente testamos se as variáveis possuem ou não distribuição normal, por intermédio do teste de Kolmogorov-Smirnov:

\begin{tabular}{|l|r|r|}
\hline \multicolumn{3}{|c|}{ GE } \\
\hline Dimensões & $\begin{array}{c}\text { Kolmogorov- } \\
\text { Smirnov Z }\end{array}$ & \multicolumn{1}{c|}{$\mathbf{p}$} \\
\hline AUTOEFICÁCIA & 1,184 &, 121 \\
\hline MECE & 1,246 &, 090 \\
\hline MEINTRO & 1,569 &, 015 \\
\hline MEIDEN & 1,594 &, 012 \\
\hline MIVE &, 817 &, 516 \\
\hline MIR & 1,805 &, 003 \\
\hline MIS & 1,268 &, 080 \\
\hline
\end{tabular}




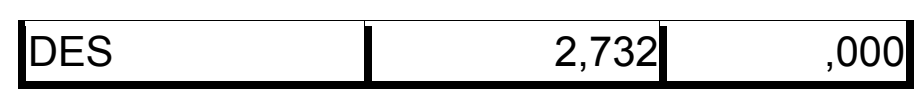

\begin{tabular}{|l|r|r|}
\hline \multicolumn{3}{|c|}{ GC } \\
\hline \multicolumn{1}{|c|}{ Dimensões } & $\begin{array}{r}\text { Kolmogorov- } \\
\text { Smirnov Z }\end{array}$ & \multicolumn{1}{c|}{$\mathbf{p}$} \\
\hline AUTOEFICÁCIA & 1,115 &, 166 \\
\hline MECE & 1,200 &, 112 \\
\hline MEINTRO & 1,222 &, 101 \\
\hline MEIDEN & 2,219 &, 000 \\
\hline MIVE & 1,298 &, 069 \\
\hline MIR & 1,180 &, 123 \\
\hline MIS & 1,432 &, 033 \\
\hline DES & 2,326 &, 000 \\
\hline
\end{tabular}

Portanto, como rejeitamos a normalidade das variáveis MEINTRO, no GE, MEIDEN, em ambos os grupos, MIR, no GE, MIS, no GC e DES, em ambos os grupos, nestas variáveis utilizamos o teste não-paramétrico de Mann-Whitney. Nas demais, aplicamos o teste de $\mathrm{t}$ de Student para amostras independentes. Verificou-se que:

- AUTOEFICÁCIA: $t=0,59 p=0,56$

Não há diferença significativa.

- $\mathrm{MECE}: \mathrm{t}=1,14 \quad \mathrm{p}=0,26$

Não há diferença significativa.

- MEINTRO: $Z=3,09 p=0,002^{*}$

Há diferença significativa, o GE possui valores significativamente superiores.

- MEIDEN: $Z=1,22 \quad p=0,22$

Não há diferença significativa.

- MIVE: $\mathrm{t}=1,23 \quad \mathrm{p}=0,22$

Não há diferença significativa.

- MIR: $Z=0,12 p=0,91$

Não há diferença significativa.

- MIS: $t=0,13 p=0,90$

Não há diferença significativa.

- DES: $Z=2,57 p=0,01^{*}$ 
Há diferença significativa, o GC possui valores significativamente superiores.

Seguem os intervalos de confiança de $95 \%$ para as diferenças de médias:

\begin{tabular}{|c|c|c|}
\hline \multicolumn{3}{|c|}{ t-test for Equality of Means } \\
\hline \multicolumn{3}{|c|}{$95 \%$ Confidence Interval of the Difference } \\
\hline Dimensões & Lower & Upper \\
\hline AUTOEFICÁCIA &,- 50664 & ,27546 \\
\hline MECE &,- 24340 & 89340 \\
\hline MEINTRO &,- 07712 & ,76242 \\
\hline MEIDEN &,- 14756 & ,48089 \\
\hline MIVE &,- 87091 & ,20816 \\
\hline MIR &,- 48222 & 61850 \\
\hline MIS &,- 70485 & ,48524 \\
\hline DES &,- 75038 &,- 11138 \\
\hline
\end{tabular}

Para finalizar a apresentação dos resultados, seguem as estatísticas descritivas:

\begin{tabular}{|c|c|c|c|c|c|c|c|c|c|}
\hline \multicolumn{2}{|c|}{ GRUPO } & AUTOEFICÁCIA & MECE & MEINTRO & MEIDEN & MIVE & MIR & MIS & DES \\
\hline \multirow{5}{*}{ Experimental } & Median & 4,2250 & 4,5000 & 5,0000 & 5,0000 & 4,0000 & 4,5000 & 4,5000 & 1,0000 \\
\hline & Minimum & 1,60 & ,75 & 1,50 & 2,50 & 1,25 & 1,00 & 1,00 & ,75 \\
\hline & Maximum & 4,95 & 5,00 & 5,00 & 5,00 & 5,00 & 5,00 & 5,00 & 1,75 \\
\hline & Mean & 3,9800 & 4,0750 & 4,4750 & 4,6667 & 3,6833 & 4,1417 & 3,9417 & 1,0250 \\
\hline & $\begin{array}{l}\text { Std. } \\
\text { Deviation }\end{array}$ & ,81236 & 1,21085 & 93161 & ,57361 & 1,07466 & 1,08414 & 1,23993 & 15186 \\
\hline \multirow{5}{*}{ Controle } & Median & 4,4000 & 3,8750 & 4,3750 & 4,7500 & 4,1250 & 4,5000 & 4,5000 & 1,0000 \\
\hline & Minimum & 1,50 & 1,25 & 1,75 & 3,00 & 1,25 & 1,00 & 1,00 & 1,00 \\
\hline & Maximum & 4,95 & 5,00 & 5,00 & 5,00 & 5,00 & 5,00 & 5,00 & 4,00 \\
\hline & Mean & 4,0956 & 3,7500 & 4,1324 & 4,5000 & 4,0147 & 4,0735 & 4,0515 & 1,4559 \\
\hline & $\begin{array}{l}\text { Std. } \\
\text { Deviation }\end{array}$ & ,75231 & 1,06423 & ,74680 & 67138 & 1,08002 & 1,11214 & 1,14114 & ,90342 \\
\hline \multirow{5}{*}{ Total } & Median & 4,3500 & 4,0000 & 4,5000 & 4,7500 & 4,0000 & 4,5000 & 4,5000 & 1,0000 \\
\hline & Minimum & 1,50 & ,75 & 1,50 & 2,50 & 1,25 & 1,00 & 1,00 & ,75 \\
\hline & Maximum & 4,95 & 5,00 & 5,00 & 5,00 & 5,00 & 5,00 & 5,00 & 4,00 \\
\hline & Mean & 4,0414 & 3,9023 & 4,2930 & 4,5781 & 3,8594 & 4,1055 & 4,0000 & 1,2539 \\
\hline & $\begin{array}{l}\text { Std. } \\
\text { Deviation }\end{array}$ & ,77693 & 1,13793 & ,84932 & 62817 & 1,08184 & 1,09091 & 1,18019 & 69649, \\
\hline
\end{tabular}




\subsection{2-Experimento 3: Comparação dos Índices Identificados no Pré-Teste e os Alcançados após o Contato com o Material Didático}

\section{${ }^{*}$ Grupo Experimental (GE)}

A tabela a seguir apresenta os índices alcançados nos pré-testes em comparação aos testes realizados após o contato com o material didático, para a qual utilizamos o teste não-paramétrico de Wilcoxon para amostras pareadas:

\begin{tabular}{|l|r|r|}
\hline $\begin{array}{c}\text { Questão/Dimensões } \\
\text { Comparadas }\end{array}$ & \multicolumn{1}{c|}{$\mathbf{z}$} & \multicolumn{1}{c|}{$\mathbf{p}$} \\
\hline$a 3-a 3 a$ & $-2,714^{\mathrm{a}}$ &, 007 \\
\hline $\mathrm{a} 6-\mathrm{a} 6 \mathrm{a}$ & $-2,530^{\mathrm{a}}$ &, 011 \\
\hline $\mathrm{a} 9-\mathrm{a} 9 \mathrm{a}$ &, $000^{\mathrm{b}}$ & 1,000 \\
\hline $\mathrm{a} 12-\mathrm{a} 12 \mathrm{a}$ & $-1,414^{\mathrm{a}}$ &, 157 \\
\hline $\mathrm{a} 15-\mathrm{a} 15 \mathrm{a}$ & $-1,890^{\mathrm{a}}$ &, 059 \\
\hline $\mathrm{a} 18-\mathrm{a} 18 \mathrm{a}$ &, $000^{\mathrm{b}}$ & 1,000 \\
\hline $\mathrm{m} 1-\mathrm{m} 1 \mathrm{a}$ & $-2,121^{\mathrm{a}}$ &, 034 \\
\hline $\mathrm{m} 4-\mathrm{m} 4 \mathrm{a}$ & $-1,000^{\mathrm{a}}$ &, 317 \\
\hline $\mathrm{m} 9-\mathrm{m} 9 \mathrm{a}$ & $-1,000^{\mathrm{a}}$ &, 317 \\
\hline $\mathrm{m} 12-\mathrm{m} 12 \mathrm{a}$ &, $000^{\mathrm{b}}$ & 1,000 \\
\hline $\mathrm{m} 13-\mathrm{m} 13 a$ &, $000^{\mathrm{b}}$ & 1,000 \\
\hline $\mathrm{m} 20-\mathrm{m} 20 \mathrm{a}$ &, $000^{\mathrm{b}}$ & 1,000 \\
\hline $\mathrm{m} 24-\mathrm{m} 24 \mathrm{a}$ & $-2,646^{\mathrm{a}}$ &, 008 \\
\hline $\mathrm{m} 28-\mathrm{m} 28 \mathrm{a}$ &, $000^{\mathrm{b}}$ & 1,000 \\
\hline
\end{tabular}

Portanto, há diferença significativa nas seguintes variáveis:

- a3 (Autoeficácia para a Aprendizagem - item 3): $p=0,007^{*}$ Com o pós apresentando valores significativamente superiores aos do préexperimento.

- a6 (Autoeficácia para a Aprendizagem - item 6): $p=0,01^{*}$ Com o pós apresentando valores significativamente superiores aos do préexperimento.

- m1 (Motivação Extrínseca - Controle Externo - Questão 1): $p=0,03^{*}$ Com o pós apresentando valores significativamente superiores aos dos pré-experimentos.

- m24 (Motivação Extrínseca - Identificação - Questão 24): $p=0,008^{*}$. Portanto, com o pós apresentando valores significativamente superiores aos do pré-experimento.

Seguem as estatísticas descritivas: 


\begin{tabular}{|c|r|r|r|r|r|r|}
\hline $\begin{array}{c}\text { Questões/ } \\
\text { Dimensões }\end{array}$ & $\mathbf{N}$ & Média & $\begin{array}{r}\text { Desvio } \\
\text { Padrão }\end{array}$ & Mínimo & Máximo & Mediana \\
\hline a3a & 30 & 4,23 &, 898 & 1 & 5 & 4,00 \\
\hline a6a & 30 & 4,00 &, 871 & 2 & 5 & 4,00 \\
\hline a9a & 30 & 3,53 & 1,306 & 0 & 5 & 4,00 \\
\hline a12a & 30 & 3,37 & 1,351 & 1 & 5 & 4,00 \\
\hline a15a & 30 & 3,77 & 1,135 & 0 & 5 & 4,00 \\
\hline a18a & 30 & 3,90 & 1,094 & 1 & 5 & 4,00 \\
\hline $\mathrm{m} 1 \mathrm{a}$ & 30 & 3,30 & 1,466 & 1 & 5 & 3,00 \\
\hline $\mathrm{m} 4 a$ & 30 & 3,63 & 1,066 & 1 & 5 & 4,00 \\
\hline $\mathrm{m} 9 \mathrm{a}$ & 30 & 4,53 & 1,042 & 1 & 5 & 5,00 \\
\hline $\mathrm{m} 12 \mathrm{a}$ & 30 & 1,13 &, 571 & 1 & 4 & 1,00 \\
\hline $\mathrm{m} 13 \mathrm{a}$ & 30 & 4,20 & 1,186 & 1 & 5 & 5,00 \\
\hline $\mathrm{m} 20 \mathrm{a}$ & 30 & 3,57 & 1,165 & 1 & 5 & 4,00 \\
\hline $\mathrm{m} 24 a$ & 30 & 4,70 &, 535 & 3 & 5 & 5,00 \\
\hline $\mathrm{m} 28 \mathrm{a}$ & 30 & 4,37 & 1,326 & 1 & 5 & 5,00 \\
\hline $\mathrm{a} 3$ & 30 & 4,53 &, 819 & 1 & 5 & 5,00 \\
\hline $\mathrm{a} 6$ & 30 & 4,27 &, 740 & 3 & 5 & 4,00 \\
\hline $\mathrm{a} 9$ & 30 & 3,53 & 1,306 & 0 & 5 & 4,00 \\
\hline $\mathrm{a} 12$ & 30 & 3,43 & 1,382 & 1 & 5 & 4,00 \\
\hline $\mathrm{a} 15$ & 30 & 3,93 & 1,015 & 0 & 5 & 4,00 \\
\hline $\mathrm{a} 18$ & 30 & 3,90 & 1,094 & 1 & 5 & 4,00 \\
\hline $\mathrm{m} 1$ & 30 & 3,50 & 1,526 & 1 & 5 & 4,00 \\
\hline $\mathrm{m} 4$ & 30 & 3,67 & 1,093 & 1 & 5 & 4,00 \\
\hline $\mathrm{m} 9$ & 30 & 4,57 & 1,040 & 1 & 5 & 5,00 \\
\hline $\mathrm{m} 12$ & 30 & 1,13 &, 571 & 1 & 4 & 1,00 \\
\hline $\mathrm{m} 13$ & 30 & 4,20 & 1,186 & 1 & 5 & 5,00 \\
\hline $\mathrm{m} 20$ & 30 & 3,57 & 1,165 & 1 & 5 & 4,00 \\
\hline $\mathrm{m} 24$ & 30 & 4,93 &, 254 & 4 & 5 & 5,00 \\
\hline $\mathrm{m} 28$ & 30 & 4,37 & 1,326 & 1 & 5 & 5,00 \\
\hline & & & & & 5 \\
\hline
\end{tabular}

\section{* Grupo de Controle (GC)}

A tabela a seguir apresenta os índices alcançados nos pré-testes em comparação aos testes realizados após o contato com o material didático, para a qual utilizamos o teste não-paramétrico de Wilcoxon para amostras pareadas:

\begin{tabular}{|l|r|r|}
\hline $\begin{array}{c}\text { Questão/Dimensões } \\
\text { Comparadas }\end{array}$ & \multicolumn{1}{|c|}{$\mathbf{z}$} & \multicolumn{1}{|c|}{$\mathbf{p}$} \\
\hline $\mathrm{a} 3-\mathrm{a} 3 \mathrm{a}$ & $-1,414^{\mathrm{a}}$ &, 157 \\
\hline $\mathrm{a} 6-\mathrm{a} \mathrm{a}$ &, $000^{\mathrm{b}}$ & 1,000 \\
\hline
\end{tabular}




\begin{tabular}{|l|r|r|}
\hline$a 9-a 9 a$ &, $000^{b}$ & 1,000 \\
\hline$a 12-a 12 a$ &, $000^{b}$ & 1,000 \\
\hline$a 15-a 15 a$ &, $000^{b}$ & 1,000 \\
\hline$a 18-a 18 a$ &, $000^{b}$ & 1,000 \\
\hline$m 1-m 1 a$ &, $000^{b}$ & 1,000 \\
\hline$m 4-m 4 a$ &, $000^{b}$ & 1,000 \\
\hline$m 9-m 9 a$ &, $000^{b}$ & 1,000 \\
\hline$m 12-m 12 a$ &, $000^{b}$ & 1,000 \\
\hline$m 13-m 13 a$ &, $000^{b}$ & 1,000 \\
\hline$m 20-m 20 a$ &, $000^{b}$ & 1,000 \\
\hline$m 24-m 24 a$ &, $000^{b}$ & 1,000 \\
\hline$m 28-m 28 a$ &, $000^{b}$ & 1,000 \\
\hline
\end{tabular}

Portanto, não há diferença significativa em nenhuma variável. Seguem as estatísticas descritivas:

\begin{tabular}{|l|r|r|r|r|r|r|}
\hline $\begin{array}{l}\text { Questões/ } \\
\text { Dimensões }\end{array}$ & N & Média & $\begin{array}{r}\text { Desvio } \\
\text { Padrão }\end{array}$ & Mínimo & Máximo & Mediana \\
\hline a3a & 34 & 4,38 &, 779 & 2 & 5 & 5,00 \\
\hline a6a & 34 & 4,15 & 1,048 & 1 & 5 & 4,00 \\
\hline a9a & 34 & 3,91 &, 996 & 1 & 5 & 4,00 \\
\hline a12a & 34 & 3,35 & 1,203 & 1 & 5 & 4,00 \\
\hline a15a & 34 & 3,82 & 1,218 & 1 & 5 & 4,00 \\
\hline a18a & 34 & 4,00 &, 921 & 1 & 5 & 4,00 \\
\hline $\mathrm{m} 1 \mathrm{a}$ & 34 & 3,35 & 1,475 & 1 & 5 & 4,00 \\
\hline $\mathrm{m} 4 \mathrm{a}$ & 34 & 4,21 &, 946 & 2 & 5 & 4,00 \\
\hline $\mathrm{m} 9 \mathrm{a}$ & 34 & 3,88 &, 880 & 1 & 5 & 4,00 \\
\hline $\mathrm{m} 12 \mathrm{a}$ & 34 & 1,65 & 1,368 & 1 & 5 & 1,00 \\
\hline $\mathrm{m} 13 \mathrm{a}$ & 34 & 4,00 & 1,231 & 1 & 5 & 4,00 \\
\hline $\mathrm{m} 20 \mathrm{a}$ & 34 & 3,97 & 1,167 & 1 & 5 & 4,00 \\
\hline $\mathrm{m} 24 \mathrm{a}$ & 34 & 4,53 &, 662 & 3 & 5 & 5,00 \\
\hline $\mathrm{m} 28 \mathrm{a}$ & 34 & 4,18 & 1,193 & 1 & 5 & 5,00 \\
\hline $\mathrm{a} 3$ & 34 & 4,44 &, 786 & 2 & 5 & 5,00 \\
\hline $\mathrm{a} 6$ & 34 & 4,15 & 1,019 & 1 & 5 & 4,00 \\
\hline $\mathrm{a} 9$ & 34 & 3,91 &, 996 & 1 & 5 & 4,00 \\
\hline $\mathrm{a} 12$ & 34 & 3,35 & 1,203 & 1 & 5 & 4,00 \\
\hline $\mathrm{a} 15$ & 34 & 3,82 & 1,218 & 1 & 5 & 4,00 \\
\hline $\mathrm{a} 18$ & 34 & 4,00 &, 921 & 1 & 5 & 4,00 \\
\hline $\mathrm{m} 1$ & 34 & 3,35 & 1,475 & 1 & 5 & 4,00 \\
\hline $\mathrm{m} 4$ & 34 & 4,21 &, 946 & 2 & 5 & 4,00 \\
\hline $\mathrm{m} 9$ & 34 & 3,88 &, 880 & 1 & 5 & 4,00 \\
\hline
\end{tabular}




\begin{tabular}{|l|r|r|r|r|r|r|}
\hline $\mathrm{m} 12$ & 34 & 1,65 & 1,368 & 1 & 5 & 1,00 \\
\hline $\mathrm{m} 13$ & 34 & 4,00 & 1,231 & 1 & 5 & 4,00 \\
\hline $\mathrm{m} 20$ & 34 & 3,97 & 1,167 & 1 & 5 & 4,00 \\
\hline $\mathrm{m} 24$ & 34 & 4,53 &, 662 & 3 & 5 & 5,00 \\
\hline $\mathrm{m} 28$ & 34 & 4,18 & 1,193 & 1 & 5 & 5,00 \\
\hline
\end{tabular}

\subsection{3 -Pós-Teste - Experimento 3}

Ambos os grupos responderam a uma questão aberta, na qual puderam tratar aberta e sinceramente sobre o material ao qual tiveramacesso.

No GE, a questão proposta foi a seguinte: "o que você pensa sobre a possibilidade de controlar a velocidade navideoula?"

Dentre os alunos que se posicionaram, a grande maioria demonstrou abertamente e pelos mais variados motivos que "gostaram" da possibilidade de controlar a velocidade do vídeo, conforme segue:

- Alunos que gostaram por motivos ligados à aprendizagem (melhoria da performance da aprendizagem, facilitação da compreensão dos conteúdos e respeito ao ritmo de aprendizagem) : vinte e dois alunos (cerca de 64,8\%), conforme alguns comentários: "Interessante. Pois assim quando não estamos conseguindo acompanhar podemos diminuir a velocidade e assim acompanhar o que esta sendo passado", "Ótimo, pois cada pessoa tem uma capacidade diferente de entender o conteúdo" ou "eu acho muito interessante, pois nos da oportunidades para aprender do melhor jeito para nossa compreensão", dentre outros.

- Alunos que gostaram por motivos pessoais (por não permitir que aaula fique cansativa, por deixar a escolha para o aluno e por otimizar o tempo de estudo): oito alunos (cerca de $20,7 \%$ ), conforme alguns comentários: "pensoque sendo um pouco mais rápida a velocidade melhoria a compreensão e não ficaria uma aula cansativa", "legal para poder escolher a forma que eu quero aprender" ou "legal porque se você não gosta da aula ou acha ela chata você pode aumentar a velocidade, e mesmo se gostar você pode voltar ou pausar para prestarmais atenção e tirar as dúvidas", dentre outros.

- Ficaram indiferentes: um aluno (cerca de 2,9\%), conforme comentário: "sinceramente eu não senti nenhuma diferença". 
- Alunos que não entenderam a proposta: um aluno (cerca de $2,9 \%$ ), conforme comentário: "que talvez tenha sido para apenas 'testar' o modo da atenção de cada pessoa presente".

- Não gostaram da opção de controlar a velocidade: um aluno (cerca de aproximadamente 2,9\%). Segue comentário: "não gostei, porque assim aqueles alunos que não querem aprender ou não estão interessados muito nas aula não vão aprender direito".

- Não responderam: dois alunos (cerca de 5,8\%).

Já no GC, obtivemos os seguintes resultados:

Já no GC foi realizado o seguintequestionamento: "o que você pensa sobre a videoaula?" Neste caso, a proposta era apenas de verificar se os alunos gostam da videoaula como opção de material didático, uma vez que o GC não sabia que o GE estava tendo acesso ao material com implementações diferenciadas das habituais. A questão foi respondida por vinte e dois alunos (cerca de $73,3 \%$ ) que relataram gostar da videoaula como opção de material didático mais fácil de ser compreendido em relação aos demais materiais, como seguem comentários: "O videoaula é muito importante para quem está fazendo a graduação na modalidade EAD, principalmente quando o aluno por algum motivo não pode ir até a universidade" ou "eu particulamente gosto da videoaula"; um aluno (cerca de 3,3\%) apontou espontaneamente para a possível necessidade e/ou incidência de mudanças no uso de mídias com material didático, conforme comentário: "eu acho a videoaula uma alternativa muito interessante, acredito que novos métodos são sempre bem vindos, mudanças sempre irão acontecer. A necessidade dessas mudanças só iremos perceber com o tempo". Os demais alunos (sete alunos - cerca de $23,4 \%$ ) não responderam ao questionamento.

\subsection{4 -Experimento 3: Análise Geral dos Resultados}

Partindo dos resultados obtidos no pré-teste, no teste e no pós-teste, percebeu-se que oferecer a possibilidade de controle da videoaula pode ser uma estratégia interessante para o processo de aprendizagem, dadas algumas observações relevantes. 
Embora a maioria dos alunos (63,3\%) preferissem a velocidade convencional, um número significativo de alunos utilizou as demais opções de controle de velocidade (36,6\%: 23,3\% acelerando e 13,3\% diminuindo a velocidade) e, como pode ser verificado no pós-teste, até mesmo boa parte os alunos que utilizaram a velocidade convencional (no total: $85,5 \%$ dos alunos) reconheceram, declarando abertamente, que o controle da velocidade é importante, pois pode contribuir para a aprendizagem neste ou em outros contextos, nos quais, com uma velocidade mais lenta, seria possível compreender melhor os conteúdos (destaque para conteúdos procedimentais), ou com uma velocidade mais rápida, tornar aprendizagem de determinados conteúdos (destaque para conteúdos factuais e conceituais) mais atrativa. Ainda figuraram entre os alunosas questões relacionadas ao respeito ao ritmo de aprendizagem, à facilitação do processo de construção do conhecimento ou mesmo o fato de ampliar o desejo de persistência nos estudos pela facilidade de escolha do ritmo que melhor se adéqua ao contexto pessoal relacionado à aprendizagem de cada conteúdo.

A importância dessa proposta didática fica ainda mais clara, ao considerarmos os resultados de comparação entre o pré-teste e o teste com as escalas no GE, os quais apontaram para um aumento significativo da Autoeficácia para a Aprendizagem, da Motivação extrínseca por controle externo e da Motivação extrínseca por identificação, resultados que não se concretizaram no GC.

Ademais, na comparação direta entre os GE e o GC, ficou evidente o aumento dos níveis de Motivação extrínseca por introjeção nos integrantes do $\mathrm{GE}$, ou seja, os discentes que tiveram acesso ao controle de velocidade pressionaram a si mesmos a prosseguir a expectação do vídeo, além do fato de os alunos do GC demonstrarem maiores índices de desmotivação (ou seja, sem ou com pouco desejo de prosseguir com a expectação).

Outra questão importante a ser relatada trata-se do fato de a videoaula com controle de velocidade atender a um princípio do DU para a Aprendizagem e permitir maior acessibilidade para alunos com diferentes ritmos e dificuldades/habilidades de aprendizagem.

Os resultados obtidos se assemelham aos de outros trabalhos, nos quais o controle da velocidade da expectação de um material em áudio 
também era utilizado e apreciado pela maioria dos integrantes da amostra e recomendado como vantajoso para o processo de aprendizagem e/ou ainda como forma de tornar o material acessível a discentes com diferentes necessidades/habilidades/preferências (KIM, 1999; ROESLER; CERON; ANDRADE, 2003; YACHI, 2012).

8.4 - Proposta Didática 4 inspirada no Princípioll do DU para a Aprendizagem (PD4_DU4-CH) - Participação no Fórum, com Opções de Participação Escrita, Falada ou Gravada com Som e Imagem (Ciências Humanas)

\subsection{1-Experimento 4_CH: Comparação entre o GE e GC}

A tabela a seguirapresenta as escolhas dos discentes-participantes do GE para acesso aos conteúdos:

\begin{tabular}{|c|c|c|c|}
\hline \multicolumn{2}{|c|}{$\begin{array}{l}\text { ESTRATÉGIAS ESCOLHIDAS PELOS DISCENTES- } \\
\text { PARTICIPANTES - GE }\end{array}$} & \multirow[t]{2}{*}{$\mathbf{n}$} & \multirow[t]{2}{*}{$\%$} \\
\hline $\bar{C}$ & $\begin{array}{c}\text { DESCRIÇÃO } \\
\end{array}$ & & \\
\hline 1 & Participação escrita & 23 & 95,8 \\
\hline 2 & Participação falada (gravada com som) & 1 & 4,2 \\
\hline 3 & $\begin{array}{l}\text { Participação falada com imagem (gravada com } \\
\text { imagem e som) }\end{array}$ & 0 & 0 \\
\hline
\end{tabular}

Para a comparação entre o GE e o GC, inicialmente testamos se as variáveis possuem ou não distribuição normal através do teste de KolmogorovSmirnov:

\begin{tabular}{|l|r|c|}
\hline \multicolumn{3}{|c|}{ GE } \\
\hline \multicolumn{1}{|c|}{ Dimensões } & $\begin{array}{c}\text { Kolmogorov- } \\
\text { Smirnov } \mathbf{Z}\end{array}$ & $\mathbf{p}$ \\
\hline AUTOEFICÁCIA &, 908 &, 382 \\
\hline MECE & 1,046 &, 224 \\
\hline MEINTRO & 1,407 &, 038 \\
\hline MEIDEN & 1,030 &, 239 \\
\hline MIVE &, 896 &, 398 \\
\hline MIR & 1,168 &, 131 \\
\hline MIS & 1,090 &, 186 \\
\hline DES & 1,940 &, 001 \\
\hline
\end{tabular}

GC 


\begin{tabular}{|l|r|r|}
\hline Dimensões & $\begin{array}{c}\text { Kolmogorov } \\
\text {-Smirnov Z }\end{array}$ & $\begin{array}{c}\text { Asymp. Sig. } \\
\text { (2-tailed) }\end{array}$ \\
\hline AUTOEFICÁCIA &, 621 &, 836 \\
\hline MECE &, 795 &, 552 \\
\hline MEINTRO &, 563 &, 909 \\
\hline MEIDEN & 1,015 &, 254 \\
\hline MIVE &, 519 &, 950 \\
\hline MIR &, 985 &, 287 \\
\hline MIS &, 769 &, 595 \\
\hline DES & 1,421 &, 035 \\
\hline
\end{tabular}

Portanto, como rejeitamos a normalidade das variáveis MEINTRO, no GE e DES, em ambos os grupos, nestas variáveis utilizamos o teste nãoparamétrico de Mann-Whitney. Nas demais, aplicamos o teste de t de Student para amostras independentes:

- AUTOEFICÁCIA: $t=1,19 p=0,24$

Não há diferença significativa.

- MECE: $t=0,67 \quad p=0,51$

Não há diferença significativa.

- MEINTRO: $Z=2,00 \quad p=0,05^{*}$

Há diferença significativa, o GE possui valores significativamente superiores.

- MEIDEN: $t=1,05 \quad p=0,30$

Não há diferença significativa.

- MIVE: $t=0,41 \quad p=0,68$

Não há diferença significativa.

- MIR: $t=1,10 p=0,28$

Não há diferença significativa.

- MIS: $t=0,69 p=0,50$

Não há diferença significativa.

- DES: $Z=0,79 \quad p=0,43$

Não há diferença significativa.

Seguem os intervalos de confiança de $95 \%$ para as diferenças de médias:

\section{t-test for Equality of Means}




\begin{tabular}{|l|r|r|}
\hline \multicolumn{3}{|c|}{ 95\% Confidence Interval of the Difference } \\
\hline \multicolumn{1}{|c|}{ Dimensões } & \multicolumn{1}{c|}{ Lower } & \multicolumn{1}{c|}{ Upper } \\
\hline AUTOEFICÁCIA &,- 18760 &, 72427 \\
\hline MECE &,- 57139 & 1,13389 \\
\hline MEINTRO &, 02299 & 1,37284 \\
\hline MEIDEN &,- 34687 & 1,09687 \\
\hline MIVE &,- 67610 & 1,02193 \\
\hline MIR &,- 36401 & 1,23068 \\
\hline MIS &,- 57143 & 1,16310 \\
\hline DES & $-\mathbf{- 1 , 2 9 5 5 1}$ &, 57051 \\
\hline
\end{tabular}

Seguem, para finalizar, as estatísticas descritivas:

\begin{tabular}{|c|c|c|c|c|c|c|c|c|c|}
\hline \multicolumn{2}{|c|}{ GRUPO } & AUTOEFICÁCIA & MECE & MEINTRO & MEIDEN & MIVE & MIR & MIS & DES \\
\hline \multirow{5}{*}{ Experimental } & Median & 4,2250 & 4,0000 & 4,7500 & 4,3750 & 4,1250 & 4,2500 & 4,1250 & 1,0000 \\
\hline & Minimum & 2,10 & , 00 & 1,00 & 1,25 & ,00 & ,00 & 1,00 & ,25 \\
\hline & Maximum & 5,00 & 5,00 & 5,00 & 5,00 & 5,00 & 5,00 & 5,00 & 5,00 \\
\hline & Mean & 4,2083 & 3,6563 & 4,3229 & 4,1250 & 3,5104 & 4,0208 & 3,7083 & 1,7500 \\
\hline & $\begin{array}{l}\text { Std. } \\
\text { Deviation }\end{array}$ & ,77202 & 1,53547 & 1,02012 & 1,08598 & 1,55424 & 1,26817 & 1,49758 & 1,53226 \\
\hline \multirow{5}{*}{ Controle } & Median & 3,9750 & 3,6250 & 3,7500 & 4,0000 & 3,3750 & 4,0000 & 3,8750 & 1,0000 \\
\hline & Minimum & 2,75 &, 50 & 1,00 &, 75 & 1,00 & ,75 & 1,00 &, 50 \\
\hline & Maximum & 5,00 & 5,00 & 5,00 & 5,00 & 5,00 & 5,00 & 5,00 & 5,00 \\
\hline & Mean & 3,9400 & 3,3750 & 3,6250 & 3,7500 & 3,3375 & 3,5875 & 3,4125 & 2,1125 \\
\hline & $\begin{array}{l}\text { Std. } \\
\text { Deviation }\end{array}$ & ,71370 & 1,20443 & 1,19896 & 1,28759 & 1,15927 & 1,34818 & 1,31858 & 1,52064 \\
\hline \multirow{5}{*}{ Total } & Median & 4,0500 & 4,0000 & 4,3750 & 4,1250 & 3,6250 & 4,2500 & 4,0000 & 1,0000 \\
\hline & Minimum & 2,10 & ,00 & 1,00 & 75 & 00 & 00 & 1,00 & ,25 \\
\hline & Maximum & 5,00 & 5,00 & 5,00 & 5,00 & 5,00 & 5,00 & 5,00 & 5,00 \\
\hline & Mean & 4,0864 & 3,5284 & 4,0057 & 3,9545 & 3,4318 & 3,8239 & 3,5739 & 1,9148 \\
\hline & $\begin{array}{l}\text { Std. } \\
\text { Deviation }\end{array}$ & ,74976 & 1,38641 & 1,14690 & 1,18281 & 1,37604 & 1,30805 & 1,41069 & 1,52016 \\
\hline
\end{tabular}

8.4.2-Experimento 4_CH: Comparação dos Índices Identificados no PréTeste e os Alcançados Após o Contato com o Material

\section{* Grupo Experimental (GE)}

A tabela a seguir apresenta os índices alcançados nos pré-testes em comparação aos testes realizados após o contato com o material didático, para a qual utilizamos o teste não-paramétrico de Wilcoxon para amostras pareadas:

\begin{tabular}{|l|r|r|}
\hline $\begin{array}{c}\text { Questão/Dimensões } \\
\text { Comparadas }\end{array}$ & \multicolumn{1}{|c|}{$\boldsymbol{z}$} & \multicolumn{1}{|c|}{$\mathbf{p}$} \\
\hline a3a- a3a & $-1,633^{\mathrm{a}}$ &, 102 \\
\hline $\mathrm{a} 6-\mathrm{a} 6 \mathrm{a}$ & $-2,449^{\mathrm{a}}$ &, 014 \\
\hline $\mathrm{a} 9-\mathrm{a} 9 \mathrm{a}$ & $-2,121^{\mathrm{a}}$ &, 034 \\
\hline $\mathrm{a} 12-\mathrm{a} 12 \mathrm{a}$ & $-1,717^{\mathrm{a}}$ &, 086 \\
\hline
\end{tabular}




\begin{tabular}{|l|r|r|}
\hline$a 15-a 15 a$ & $-1,667^{\mathrm{a}}$ &, 096 \\
\hline$a 18-a 18 a$ &,$- 184^{\mathrm{a}}$ &, 854 \\
\hline$m 1-m 1 a$ & $-1,897^{\mathrm{a}}$ &, 058 \\
\hline$m 4-m 4 a$ &,$- 447^{\mathrm{b}}$ &, 655 \\
\hline$m 9-m 9 a$ & $-2,449^{\mathrm{a}}$ &, 014 \\
\hline$m 12-m 12 a$ & $-1,633^{\mathrm{b}}$ &, 102 \\
\hline$m 13-m 13 a$ & $-1,000^{\mathrm{a}}$ &, 317 \\
\hline$m 20-m 20 a$ &,$- 378^{\mathrm{a}}$ &, 705 \\
\hline$m 24-m 24 a$ & $-2,460^{\mathrm{a}}$ &, 014 \\
\hline$m 28-m 28 a$ & $-1,732^{\mathrm{a}}$ &, 083 \\
\hline
\end{tabular}

Portanto, há diferença significativa nas seguintes variáveis:

- a6 (Autoeficácia para aprendizagem - Item 6): $p=0,01^{*}$. Portanto, com o pós apresentando valores significativamente superiores aos do pré-experimento.

- a9 (Autoeficácia para aprendizagem - Item 9): $p=0,03^{*}$. Portanto, com o pós apresentando valores significativamente superiores aos do pré-experimento.

- m9 (Motivação Extrínseca - Introjeção - Questão 9): $p=0,01^{*}$. Portanto, com o pós apresentando valores significativamente superiores aos do pré-experimento.

- m24 (Motivação Extrínseca - Identificação - Questão 24): p = 0,01*. Portanto, com o pós apresentando valores significativamente superiores aos do pré-experimento.

Seguem estatísticas descritivas:

\begin{tabular}{|c|r|r|r|r|r|r|}
\hline Dimensões & $\mathbf{N}$ & Média & $\begin{array}{c}\text { Desvio } \\
\text { Padrão }\end{array}$ & Mínimo & Máximo & Mediana \\
\hline $\mathrm{a} 3 \mathrm{a}$ & 24 & 4,54 &, 721 & 3 & 5 & 5,00 \\
\hline $\mathrm{a} 6 \mathrm{a}$ & 24 & 4,25 &, 944 & 2 & 5 & 4,50 \\
\hline $\mathrm{a} 9 \mathrm{a}$ & 24 & 3,63 & 1,279 & 1 & 5 & 4,00 \\
\hline $\mathrm{a} 12 \mathrm{a}$ & 24 & 3,54 & 1,215 & 2 & 5 & 4,00 \\
\hline $\mathrm{a} 15 \mathrm{a}$ & 24 & 3,67 & 1,435 & 0 & 5 & 4,00 \\
\hline $\mathrm{a} 18 \mathrm{a}$ & 24 & 3,92 & 1,381 & 0 & 5 & 4,00 \\
\hline $\mathrm{m} 1 \mathrm{a}$ & 24 & 2,88 & 1,727 & 1 & 5 & 2,50 \\
\hline $\mathrm{m} 4 \mathrm{a}$ & 24 & 3,79 & 1,351 & 1 & 5 & 4,00 \\
\hline $\mathrm{m} 9 \mathrm{a}$ & 24 & 4,29 & 1,122 & 0 & 5 & 5,00 \\
\hline $\mathrm{m} 12 \mathrm{a}$ & 24 & 2,17 & 1,606 & 1 & 5 & 1,00 \\
\hline $\mathrm{m} 13 a$ & 24 & 4,17 & 1,239 & 1 & 5 & 5,00 \\
\hline $\mathrm{m} 20 \mathrm{a}$ & 24 & 3,71 & 1,459 & 0 & 5 & 4,00 \\
\hline
\end{tabular}




\begin{tabular}{|c|r|r|r|r|r|r|}
\hline $\mathrm{m} 24 a$ & 24 & 4,08 & 1,283 & 0 & 5 & 4,00 \\
\hline $\mathrm{m} 28 \mathrm{a}$ & 24 & 3,92 & 1,501 & 1 & 5 & 4,50 \\
\hline $\mathrm{a} 3$ & 24 & 4,50 &, 780 & 2 & 5 & 5,00 \\
\hline $\mathrm{a} 6$ & 24 & 4,71 &, 624 & 3 & 5 & 5,00 \\
\hline $\mathrm{a} 9$ & 24 & 3,88 & 1,227 & 1 & 5 & 4,00 \\
\hline $\mathrm{a} 12$ & 24 & 3,92 & 1,139 & 0 & 5 & 4,00 \\
\hline $\mathrm{a} 15$ & 24 & 3,92 & 1,472 & 0 & 5 & 4,00 \\
\hline $\mathrm{a} 18$ & 24 & 4,04 & 1,459 & 0 & 5 & 4,50 \\
\hline $\mathrm{m} 1$ & 24 & 3,13 & 1,801 & 0 & 5 & 3,50 \\
\hline $\mathrm{m} 4$ & 24 & 3,71 & 1,546 & 0 & 5 & 4,00 \\
\hline $\mathrm{m} 9$ & 24 & 4,54 & 1,103 & 0 & 5 & 5,00 \\
\hline $\mathrm{m} 12$ & 24 & 1,75 & 1,595 & 0 & 5 & 1,00 \\
\hline $\mathrm{m} 13$ & 24 & 4,25 & 1,391 & 0 & 5 & 5,00 \\
\hline $\mathrm{m} 20$ & 24 & 3,71 & 1,706 & 0 & 5 & 4,50 \\
\hline $\mathrm{m} 24$ & 24 & 4,46 & 1,285 & 0 & 5 & 5,00 \\
\hline $\mathrm{m} 28$ & 24 & 4,04 & 1,546 & 1 & 5 & 5,00 \\
\hline
\end{tabular}

\section{* Grupo de Controle (GC)}

A tabela a seguir apresenta os índices alcançados nos pré-testes em comparação aos testes realizados após o contato com o material didático, para a qual utilizamos o teste não-paramétrico de Wilcoxon para amostras pareadas:

\begin{tabular}{|c|c|c|}
\hline $\begin{array}{l}\text { Questão/Dimensões } \\
\text { Comparadas }\end{array}$ & $\mathbf{Z}$ & $\mathbf{p}$ \\
\hline a3 - a3a & $-1,000^{a}$ & ,317 \\
\hline$a 6-a 6 a$ & $-1,000^{a}$ & ,317 \\
\hline a9 - a9a &,- 577 &, 564 \\
\hline$a 12-a 12 a$ &, $000^{b}$ & 1,000 \\
\hline$a 15-a 15 a$ & $-1,000^{a}$ & ,317 \\
\hline a18 - a18a & $-1,000^{c}$ & 317 \\
\hline $\mathrm{m} 1-\mathrm{m} 1 \mathrm{a}$ & $-1,000^{a}$ & ,317 \\
\hline $\mathrm{m} 4-\mathrm{m} 4 \mathrm{a}$ & $-1,000^{a}$ & ,317 \\
\hline$m 9-m 9 a$ &, $000^{b}$ & 1,000 \\
\hline $\mathrm{m} 12-\mathrm{m} 12 \mathrm{a}$ & $-1,414^{c}$ & , 157 \\
\hline $\mathrm{m} 13-\mathrm{m} 13 a$ & $-1,000^{c}$ & ,317 \\
\hline $\mathrm{m} 20-\mathrm{m} 20 \mathrm{a}$ & $-1,069$ & ,285 \\
\hline $\mathrm{m} 24-\mathrm{m} 24 a$ &,- 816 & ,414 \\
\hline m28 - m28a &,$- 447^{a}$ & ,655 \\
\hline
\end{tabular}

Portanto, não há diferença significativa em nenhuma variável.

Seguem as estatísticas descritivas: 


\begin{tabular}{|c|c|c|c|c|c|c|}
\hline Dimensões & $\mathbf{N}$ & Média & $\begin{array}{l}\text { Desvio } \\
\text { Padrão }\end{array}$ & Mínimo & Máximo & Mediana \\
\hline a3a & 20 & 4,55 & ,605 & 3 & 5 & 5,00 \\
\hline$a 6 a$ & 20 & 4,10 & ,788 & 3 & 5 & 4,00 \\
\hline a9a & 20 & 3,50 & 1,318 & 1 & 5 & 3,50 \\
\hline a12a & 20 & 3,70 & 1,031 & 2 & 5 & 4,00 \\
\hline a15a & 20 & 3,95 & 1,050 & 1 & 5 & 4,00 \\
\hline a18a & 20 & 3,90 & 1,119 & 1 & 5 & 4,00 \\
\hline $\mathrm{m} 1 \mathrm{a}$ & 20 & 2,70 & 1,342 & 1 & 5 & 3,00 \\
\hline $\mathrm{m} 4 \mathrm{a}$ & 20 & 2,70 & 1,593 & 0 & 5 & 3,00 \\
\hline $\mathrm{m} 9 \mathrm{a}$ & 20 & 3,90 & 1,518 & 0 & 5 & 4,50 \\
\hline $\mathrm{m} 12 \mathrm{a}$ & 20 & 2,30 & 1,559 & 0 & 5 & 2,00 \\
\hline $\mathrm{m} 13 a$ & 20 & 3,60 & 1,465 & 0 & 5 & 4,00 \\
\hline $\mathrm{m} 20 \mathrm{a}$ & 20 & 3,70 & 1,174 & 1 & 5 & 4,00 \\
\hline $\mathrm{m} 24 \mathrm{a}$ & 20 & 3,75 & 1,410 & 0 & 5 & 4,00 \\
\hline $\mathrm{m} 28 \mathrm{a}$ & 20 & 3,80 & 1,473 & 0 & 5 & 4,00 \\
\hline a3 & 20 & 4,60 & ,503 & 4 & 5 & 5,00 \\
\hline a6 & 20 & 4,15 & ,745 & 3 & 5 & 4,00 \\
\hline a9 & 20 & 3,55 & 1,317 & 1 & 5 & 4,00 \\
\hline a12 & 20 & 3,70 & 1,031 & 2 & 5 & 4,00 \\
\hline a15 & 20 & 4,00 & 1,026 & 1 & 5 & 4,00 \\
\hline a18 & 20 & 3,75 & 1,410 & 0 & 5 & 4,00 \\
\hline $\mathrm{m} 1$ & 20 & 2,75 & 1,410 & 1 & 5 & 3,00 \\
\hline $\mathrm{m} 4$ & 20 & 2,90 & 1,483 & 0 & 5 & 3,00 \\
\hline $\mathrm{m} 9$ & 20 & 3,90 & 1,518 & 0 & 5 & 4,50 \\
\hline $\mathrm{m} 12$ & 20 & 2,20 & 1,609 & 0 & 5 & 1,00 \\
\hline $\mathrm{m} 13$ & 20 & 3,55 & 1,538 & 0 & 5 & 4,00 \\
\hline $\mathrm{m} 20$ & 20 & 3,60 & 1,429 & 0 & 5 & 4,00 \\
\hline m24 & 20 & 3,75 & 1,410 & 0 & 5 & 4,00 \\
\hline $\mathrm{m} 28$ & 20 & 3,85 & 1,461 & 0 & 5 & 4,00 \\
\hline
\end{tabular}

\subsection{3 -Experimento 4_CH: Pós-teste}

Ambos os grupos responderam a uma questão aberta, na qual puderam tratar aberta e sinceramente sobre o material ao qual tiveram acesso.

No GE a questão proposta foi a seguinte: "o que você pensa sobre a ferramenta de aprendizagem 'Fórum', com possibilidades diversas de participação?" 
Dentre os alunos que se posicionaram, a grande maioria demonstrou abertamente e pelos mais variados motivos que 'gostam' de escolher a forma de participação, conforme segue:

- Alunos que gostaram por motivos ligados à aprendizagem (por trazer a oportunidade de aprender mais, por ser útil para a aprendizagem, por complementar a formação ou por aprender mais interagindo com colegas): vinte e dois alunos (cerca de 45,8\%), conforme alguns comentários: "interessante e muito útil para a aprendizagem" ou "assim, a ferramenta ajuda complementar a formação do individuo".

- Alunos que gostaram por motivos pessoais (por permitir fácil acesso a pessoas de diferentes preferências, por dar uma opção diferente a quem tem timidez ou por tornar a interatividade mais atrativa): nove alunos (cerca de 37,8\%), conforme alguns comentários: "eu acho muito interessante, já que é uma ferramenta ficou mais prática, fácil de usar e acessivel a todos", "é bom para quem tem dificuldade de escrever" ou "dessa forma, permite a participação de todos os alunos, todos podem interagir expondo suas opiniões e diferenças".

- Gostaram da interatividade no aplicativo que oferece diferentes opções de participação, embora tenham restrições quanto seu uso por motivos pessoais: um aluno (cerca de 4,1\%) "é uma boa ferramenta ajuda a complementar os estudos porém muitos não tem tempo e dificulta a participação".

- Não responderam: três alunos (cerca de 12,5\%).

Já no GC foi realizado o questionamento: "o que você pensa sobre a ferramenta fórum?"Neste caso, a proposta era apenas de verificar se os alunos gostam do Fórum como opção para realizar a avaliação continuada e colaborativa, uma vez que o GC não sabia que o GE estava tendo acesso à ferramenta com implementações diferenciadas das habituais. Os alunos se posicionaram da seguinte maneira:

- Gostam do fórum e o entendem como opção para interagir com colegas e aprender de forma colaborativa, como seguem comentários: treze alunos (65\%), "a ferramenta fórum é importantíssima, pois faz com que alunos e professores se interagem 
e fiquem por dentro dos assuntos da sala" ou "eu acho muito interessante, pois amplia a interação do professor e aluno e com os colegas de sala e também é uma forma de expressarmos nossa opinião".

- Defendem que a eficácia do fórum depende do uso que é feito da ferramenta: um aluno (5\%), conforme segue comentário "dependendo de como se é utilizado, pode se tornar útil, passando conhecimentos".

- Não gostam do fórum: dois alunos (15\%) por o entenderem como desnecessário e/ou dispensável, conforme comentário: "acho que não tem muita necessidade na formação Superior."

- Não responderam ao questionamento: quatro alunos (20\%).

8.5 - Proposta Didática 4 inspirada no Princípioll do DU para a Aprendizagem (PD4_DU4-CT) - Participação no Fórum, com Opções de Participação Escrita, Falada ou Gravada com Som e Imagem (Ciências Humanas)

\subsection{1 -Experimento 4_CT: Comparação entre o GE e GC}

A tabela a seguirapresenta as escolhas dos discentes-participantes do GE para acesso aos conteúdos:

\begin{tabular}{|c|l|c|c|}
\hline \multicolumn{2}{|c|}{ ESTRATÉGIAS ESCOLHIDAS PELOS DISCENTES- } & \multirow{1}{|c|}{ PARTICIPANTES - GE } & \multirow{1}{|c|}{ DESCRIÇÃO } \\
\hline C & \multicolumn{1}{|c|}{} & \\
\hline 1 & Participação escrita & 7 & 70 \\
\hline 2 & Participação falada (gravada com som) & 1 & 10 \\
\hline 3 & $\begin{array}{l}\text { Participação falada com imagem (gravada com } \\
\text { imagem e som) }\end{array}$ & 2 & 20 \\
\hline
\end{tabular}

A seguir, é apresentada a comparação entre os GE e o GC. Para tanto, inicialmente testamos se as variáveis possuem ou não distribuição normal através do teste de Kolmogorov-Smirnov:

\begin{tabular}{|l|r|r|}
\hline \multicolumn{3}{|c|}{ GE } \\
\hline \multicolumn{1}{|c|}{ Dimensões } & $\begin{array}{c}\text { Kolmogorov- } \\
\text { Smirnov } \mathbf{Z}\end{array}$ & \multicolumn{1}{c|}{$\mathbf{p}$} \\
\hline AUTOEFICÁCIA & 1,010 &, 260 \\
\hline MECE &, 366 &, 999 \\
\hline MEINTRO &, 475 &, 978 \\
\hline MEIDEN &, 536 &, 936 \\
\hline
\end{tabular}




\begin{tabular}{|l|r|r|}
\hline MIVE &, 538 &, 935 \\
\hline MIR &, 670 &, 760 \\
\hline MIS &, 334 & 1,000 \\
\hline DES &, 674 &, 754 \\
\hline
\end{tabular}

\begin{tabular}{|l|r|r|}
\hline \multicolumn{3}{|c|}{ GC } \\
\hline \multicolumn{1}{|c|}{ Dimensões } & $\begin{array}{c}\text { Kolmogorov- } \\
\text { Smirnov } \mathbf{~}\end{array}$ & \multicolumn{1}{c|}{$\mathbf{p}$} \\
\hline AUTOEFICÁCIA &, 739 &, 645 \\
\hline MECE &, 910 &, 379 \\
\hline MEINTRO &, 778 &, 581 \\
\hline MEIDEN &, 752 &, 625 \\
\hline MIVE &, 587 &, 881 \\
\hline MIR &, 448 &, 988 \\
\hline MIS &, 742 &, 640 \\
\hline DES &, 716 &, 684 \\
\hline
\end{tabular}

Portanto, não rejeitamos a normalidade de nenhuma das variáveis. aplicamos o teste de $t$ de Student para amostras independentes.

- AUtOEFICÁCIA: $\mathrm{t}=2,47 \mathrm{p}=0,02^{*}$

Há diferença significativa, O GE possui valores significativamente superiores.

- MECE: $t=0,76 \quad p=0,46$

Não há diferença significativa.

- MEINTRO: $t=1,33 \quad p=0,21$

Não há diferença significativa.

- MEIDEN: $t=1,34 \quad p=0,20$

Não há diferença significativa.

- MIVE: $t=1,63 \quad p=0,12$

Não há diferença significativa.

- MIR: $t=1,32 p=0,20$

Não há diferença significativa.

- MIS: $\mathrm{t}=0,98 \mathrm{p}=0,34$

Não há diferença significativa.

- DES: $t=0,00 \quad p=1,00$ 
Não há diferença significativa.

Seguem descrição dos intervalos de confiança de 95\% para as diferenças de médias:

\begin{tabular}{|l|l|l|l|}
\hline \multicolumn{2}{|c|}{ Vevene's Test for Equality of } & \multicolumn{2}{l|}{ t-test for Equality of Means } \\
\hline \multicolumn{3}{|c|}{ 95\% Confidence Interval of the Difference } \\
\hline Dimensões & Sig. & Lower & Upper \\
\hline AUTOEFICÁCIA &, 644 &, 16852 & 2,10148 \\
\hline MECE &, 002 &,- 93982 & 1,98982 \\
\hline MEINTRO &, 001 &,- 53268 & 2,23268 \\
\hline MEIDEN &, 001 &,- 57224 & 2,47224 \\
\hline MIVE &, 046 &,- 30039 & 2,25039 \\
\hline MIR &, 107 &,- 50206 & 2,20206 \\
\hline MIS &, 027 &,- 81451 & 2,21451 \\
\hline DES &, 792 & $-1,29462$ & 1,29462 \\
\hline
\end{tabular}

Para finalizar, seguem as estatísticas descritivas:

\begin{tabular}{|c|c|c|c|c|c|c|c|c|c|}
\hline \multicolumn{2}{|c|}{ GRUPO } & AUTOEFICÁCIA & MECE & MEINTRO & MEIDEN & MIVE & MIR & MIS & DES \\
\hline \multirow{5}{*}{ Experimental } & Median & 4,3000 & 3,3750 & 3,7500 & 3,8750 & 3,3750 & 3,1250 & 3,1250 & 2,3750 \\
\hline & Minimum & 1,70 & 1,00 & 2,00 & 1,50 & 1,75 & 1,00 & 1,00 & 1,00 \\
\hline & Maximum & 4,90 & 5,00 & 5,00 & 5,00 & 5,00 & 5,00 & 4,75 & 4,50 \\
\hline & Mean & 3,9450 & 3,3000 & 3,6500 & 3,7000 & 3,3250 & 3,2500 & 3,1000 & 2,3500 \\
\hline & $\begin{array}{l}\text { Std. } \\
\text { Deviation }\end{array}$ & 1,00428 & 1,14746 & ,90676 & 1,08525 & ,97930 & 1,12423 & 1,20301 & 1,23716 \\
\hline \multirow{5}{*}{ Controle } & Median & 2,3750 & 2,8750 & 3,0000 & 2,6250 & 2,0000 & 2,3750 & 1,7500 & 1,8750 \\
\hline & Minimum & 1,65 & ,75 & ,75 & ,50 & , 00 & , 00 & , 00 & 1,00 \\
\hline & Maximum & 4,80 & 4,75 & 5,00 & 5,00 & 4,50 & 4,75 & 5,00 & 5,00 \\
\hline & Mean & 2,8100 & 2,7750 & 2,8000 & 2,7500 & 2,3500 & 2,4000 & 2,4000 & 2,3500 \\
\hline & $\begin{array}{l}\text { Std. } \\
\text { Deviation }\end{array}$ & 1,05246 & 1,84636 & 1,81353 & 1,96497 & 1,61675 & 1,69640 & 1,90102 & 1,50555 \\
\hline \multirow{5}{*}{ Total } & Median & 3,6500 & 3,3750 & 3,7500 & 3,7500 & 3,1250 & 3,0000 & 2,8750 & 2,1250 \\
\hline & Minimum & 1,65 & ,75 & ,75 & ,50 & ,00 & ,00 & , 00 & 1,00 \\
\hline & Maximum & 4,90 & 5,00 & 5,00 & 5,00 & 5,00 & 5,00 & 5,00 & 5,00 \\
\hline & Mean & 3,3775 & 3,0375 & 3,2250 & 3,2250 & 2,8375 & 2,8250 & 2,7500 & 2,3500 \\
\hline & $\begin{array}{l}\text { Std. } \\
\text { Deviation }\end{array}$ & 1,15821 & 1,52020 & 1,46202 & 1,61998 & 1,39377 & 1,46696 & 1,58944 & 1,34115 \\
\hline
\end{tabular}


8.5.2 -Experimento 4_CT: Comparação dos Índices Identificados no PréTeste e os Alcançados Após o Contato com o Material

\section{* Grupo Experimental (GE)}

A tabela a seguir apresenta os índices alcançados nos pré-testes em comparação aos testes realizados após o contato com o material didático, para a qual utilizamos o teste não-paramétrico de Wilcoxon para amostras pareadas:

\begin{tabular}{|c|r|r|}
\hline $\begin{array}{c}\text { Questão/Dimensões } \\
\text { Comparadas }\end{array}$ & \multicolumn{1}{c|}{$\mathbf{z}$} & \multicolumn{1}{c|}{$\mathbf{p}$} \\
\hline $\mathrm{a} 3-\mathrm{a} 3 \mathrm{a}$ & $-2,000^{\mathrm{a}}$ &, 046 \\
\hline $\mathrm{a} 6-\mathrm{a} 6 \mathrm{a}$ & $-2,000^{\mathrm{a}}$ &, 046 \\
\hline $\mathrm{a} 9-\mathrm{a} 9 \mathrm{a}$ & $-2,000^{\mathrm{a}}$ &, 046 \\
\hline $\mathrm{a} 12-\mathrm{a} 12 \mathrm{a}$ & $-1,000^{\mathrm{a}}$ &, 317 \\
\hline $\mathrm{a} 15-\mathrm{a} 15 \mathrm{a}$ & $-1,000^{\mathrm{a}}$ &, 317 \\
\hline $\mathrm{a} 18-\mathrm{a} 18 \mathrm{a}$ & $-1,633^{\mathrm{a}}$ &, 102 \\
\hline $\mathrm{m} 1-\mathrm{m} 1 \mathrm{a}$ & $-1,414^{\mathrm{a}}$ &, 157 \\
\hline $\mathrm{m} 4-\mathrm{m} 4 \mathrm{a}$ &, $000^{\mathrm{b}}$ & 1,000 \\
\hline $\mathrm{m} 9-\mathrm{m} 9 \mathrm{a}$ & $-1,000^{\mathrm{a}}$ &, 317 \\
\hline $\mathrm{m} 12-\mathrm{m} 12 \mathrm{a}$ &, $000^{\mathrm{b}}$ & 1,000 \\
\hline $\mathrm{m} 13-\mathrm{m} 13 \mathrm{a}$ &, $000^{\mathrm{b}}$ & 1,000 \\
\hline $\mathrm{m} 20-\mathrm{m} 20 \mathrm{a}$ & $-2,236^{\mathrm{a}}$ &, 025 \\
\hline $\mathrm{m} 24-\mathrm{m} 24 \mathrm{a}$ & $-1,414^{\mathrm{a}}$ &, 157 \\
\hline $\mathrm{m} 28-\mathrm{m} 28 \mathrm{a}$ & $-1,000^{\mathrm{a}}$ &, 317 \\
\hline
\end{tabular}

Portanto, há diferença significativa nas seguintes variáveis:

- a3 (Autoeficácia para a Aprendizagem - Item 3): $p=0,05^{*}$. Portanto, com o pós apresentando valores significativamente superiores aos do pré-experimento.

- a6 (Autoeficácia para a Aprendizagem - Item 6): $p=0,05^{*}$. Portanto, com o pós apresentando valores significativamente superiores aos do pré-experimento.

- a9 (Autoeficácia para a Aprendizagem - Item 9): $p=0,05^{*}$. Portanto, com o pós apresentando valores significativamente superiores aos do pré-experimento.

- m20 (Motivação Intrínseca para Realização - Questão 20): p = 0,03*. Portanto, com o pós apresentando valores significativamente superiores aos do pré-experimento. 
Seguem as estatísticas descritivas:

\begin{tabular}{|l|r|r|r|r|r|r|}
\hline Dimensões & \multicolumn{1}{|c|}{$\mathbf{N}$} & Média & $\begin{array}{r}\text { Desvio } \\
\text { Padrão }\end{array}$ & Mínimo & Máximo & Mediana \\
\hline a3a & 10 & 3,90 &, 994 & 2 & 5 & 4,00 \\
\hline a6a & 10 & 4,20 & 1,033 & 2 & 5 & 4,50 \\
\hline a9a & 10 & 4,00 & 1,633 & 0 & 5 & 5,00 \\
\hline $\mathrm{a} 12 \mathrm{a}$ & 10 & 3,60 & 1,350 & 1 & 5 & 4,00 \\
\hline $\mathrm{a} 15 \mathrm{a}$ & 10 & 3,90 &, 876 & 3 & 5 & 4,00 \\
\hline $\mathrm{a} 18 \mathrm{a}$ & 10 & 3,50 & 1,434 & 1 & 5 & 4,00 \\
\hline $\mathrm{m} 1 \mathrm{a}$ & 10 & 2,80 & 1,317 & 1 & 5 & 3,00 \\
\hline $\mathrm{m} 4 \mathrm{a}$ & 10 & 2,90 & 1,449 & 1 & 5 & 3,00 \\
\hline $\mathrm{m} 9 \mathrm{a}$ & 10 & 3,50 & 1,509 & 0 & 5 & 3,50 \\
\hline $\mathrm{m} 12 \mathrm{a}$ & 10 & 2,40 & 1,075 & 1 & 4 & 2,00 \\
\hline $\mathrm{m} 13 \mathrm{a}$ & 10 & 3,30 & 1,160 & 1 & 5 & 3,50 \\
\hline $\mathrm{m} 20 \mathrm{a}$ & 10 & 2,70 & 1,252 & 1 & 5 & 3,00 \\
\hline $\mathrm{m} 24 \mathrm{a}$ & 10 & 3,40 & 1,776 & 0 & 5 & 3,50 \\
\hline $\mathrm{m} 28 \mathrm{a}$ & 10 & 3,00 & 1,700 & 0 & 5 & 3,50 \\
\hline $\mathrm{a} 3$ & 10 & 4,10 &, 876 & 3 & 5 & 4,00 \\
\hline $\mathrm{a} 6$ & 10 & 4,30 &, 949 & 2 & 5 & 4,50 \\
\hline $\mathrm{a} 9$ & 10 & 4,10 & 1,595 & 0 & 5 & 5,00 \\
\hline $\mathrm{a} 12$ & 10 & 3,70 & 1,337 & 1 & 5 & 4,00 \\
\hline $\mathrm{a} 15$ & 10 & 4,00 &, 816 & 3 & 5 & 4,00 \\
\hline $\mathrm{a} 18$ & 10 & 3,90 & 1,287 & 1 & 5 & 4,00 \\
\hline $\mathrm{m} 1$ & 10 & 3,00 & 1,333 & 1 & 5 & 3,00 \\
\hline $\mathrm{m} 4$ & 10 & 2,90 & 1,449 & 1 & 5 & 3,00 \\
\hline $\mathrm{m} 9$ & 10 & 3,60 & 1,506 & 0 & 5 & 4,00 \\
\hline $\mathrm{m} 12$ & 10 & 2,60 & 1,174 & 1 & 4 & 2,50 \\
\hline $\mathrm{m} 13$ & 10 & 3,30 & 1,160 & 1 & 5 & 3,50 \\
\hline $\mathrm{m} 20$ & 10 & 3,20 & 1,229 & 1 & 5 & 3,50 \\
\hline $\mathrm{m} 24$ & 10 & 3,60 & 1,838 & 0 & 5 & 4,50 \\
\hline $\mathrm{m} 28$ & 10 & 3,30 & 1,337 & 1 & 5 & 3,50 \\
\hline
\end{tabular}

\section{* Grupo de Controle (GC)}

A tabela a seguir apresenta os índices alcançados nos pré-testes em comparação aos testes realizados após o contato com o material didático, para a qual utilizamos o teste não-paramétrico de Wilcoxon para amostras pareadas:

\begin{tabular}{|l|c|c|}
\hline $\begin{array}{c}\text { Questão/Dimensões } \\
\text { Comparadas }\end{array}$ & $\mathbf{Z}$ & $\mathbf{p}$ \\
\hline $\mathrm{a} 3$ - a3a & $-1,000^{2}$ &, 317 \\
\hline
\end{tabular}




\begin{tabular}{|l|r|r|}
\hline$a 6-a 6 a$ & $-1,000^{a}$ &, 317 \\
\hline$a 9-a 9 a$ & $-1,000^{a}$ &, 317 \\
\hline$a 12-a 12 a$ & $-1,000^{a}$ &, 317 \\
\hline$a 15-a 15 a$ & $-1,000^{b}$ &, 317 \\
\hline$a 18-a 18 a$ & $-1,342^{b}$ &, 180 \\
\hline$m 1-m 1 a$ &,$- 552^{b}$ &, 581 \\
\hline$m 4-m 4 a$ &,$- 577^{b}$ &, 564 \\
\hline$m 9-m 9 a$ &, $000^{c}$ & 1,000 \\
\hline$m 12-m 12 a$ & $-1,000^{b}$ &, 317 \\
\hline$m 13-m 13 a$ &,$- 447^{a}$ &, 655 \\
\hline$m 20-m 20 a$ &,$- 447^{b}$ &, 655 \\
\hline$m 24-m 24 a$ & $-1,000^{b}$ &, 317 \\
\hline$m 28-m 28 a$ & $-1,342^{b}$ &, 180 \\
\hline
\end{tabular}

Portanto, não encontramos diferenças significativas.

Seguem as estatísticas descritivas:

\begin{tabular}{|l|r|r|r|r|r|r|}
\hline Dimensões & $\mathbf{N}$ & Média & $\begin{array}{r}\text { Desvio } \\
\text { Padrão }\end{array}$ & Mínimo & Máximo & Mediana \\
\hline a3a & 10 & 2,20 & 1,989 & 0 & 5 & 2,00 \\
\hline a6a & 10 & 2,60 & 1,776 & 0 & 5 & 3,00 \\
\hline a9a & 10 & 2,80 & 1,989 & 0 & 5 & 3,00 \\
\hline a12a & 10 & 2,40 & 1,838 & 0 & 5 & 2,00 \\
\hline a15a & 10 & 2,80 & 1,687 & 0 & 5 & 3,00 \\
\hline a18a & 10 & 3,00 & 1,633 & 0 & 5 & 3,00 \\
\hline m1a & 10 & 2,50 & 1,581 & 0 & 5 & 2,50 \\
\hline m4a & 10 & 2,90 & 1,197 & 1 & 5 & 3,00 \\
\hline m9a & 10 & 3,00 & 1,633 & 0 & 5 & 3,00 \\
\hline m12a & 10 & 2,60 & 1,647 & 1 & 5 & 2,50 \\
\hline m13a & 10 & 2,50 & 1,581 & 0 & 5 & 3,00 \\
\hline m20a & 10 & 2,00 & 1,491 & 0 & 4 & 2,00 \\
\hline m24a & 10 & 2,70 & 2,058 & 0 & 5 & 3,00 \\
\hline m28a & 10 & 2,60 & 1,838 & 0 & 5 & 2,50 \\
\hline a3 & 10 & 2,40 & 2,066 & 0 & 5 & 2,50 \\
\hline a6 & 10 & 2,70 & 1,829 & 0 & 5 & 3,50 \\
\hline a9 & 10 & 2,90 & 2,025 & 0 & 5 & 3,50 \\
\hline a12 & 10 & 2,50 & 1,900 & 0 & 5 & 2,00 \\
\hline a15 & 10 & 2,50 & 1,900 & 0 & 5 & 3,00 \\
\hline a18 & 10 & 2,50 & 2,068 & 0 & 5 & 3,00 \\
\hline m1 & 10 & 2,30 & 2,058 & 0 & 5 & 2,50 \\
\hline m4 & 2,70 & 1,767 & 0 & 5 & 3,00 \\
\hline
\end{tabular}




\begin{tabular}{|l|r|r|r|r|r|r|}
\hline $\mathrm{m} 9$ & 10 & 3,00 & 1,633 & 0 & 5 & 3,00 \\
\hline $\mathrm{m} 12$ & 10 & 2,30 & 1,829 & 0 & 5 & 1,50 \\
\hline $\mathrm{m} 13$ & 10 & 2,60 & 1,647 & 0 & 5 & 3,00 \\
\hline $\mathrm{m} 20$ & 10 & 1,90 & 1,663 & 0 & 4 & 2,00 \\
\hline $\mathrm{m} 24$ & 10 & 2,40 & 2,221 & 0 & 5 & 2,00 \\
\hline $\mathrm{m} 28$ & 10 & 2,10 & 2,132 & 0 & 5 & 1,00 \\
\hline
\end{tabular}

\subsection{3 -Experimento 4_CT: Pós-teste}

Ambos os grupos responderam a uma questão aberta, na qual puderamtratar aberta e sinceramente sobre o material ao qual tiveram acesso.

No GE a questão proposta foi a seguinte: "o que você pensa sobre a ferramenta de aprendizagem 'Fórum', com possibilidades diversas de participação?"

Dentre os alunos que se posicionaram, a grande maioria demonstrou abertamente e pelos mais variados motivos que 'gostam' de escolher a forma de participação, conforme segue:

- Alunos que gostaram por motivos pessoais (por permitir fácil acesso a pessoas de diferentes preferências ou por tornar a interatividade mais atrativa): sete alunos (70\%), conforme alguns comentários: "acho uma boa ferramenta de aprendizagem porque lá você vai ver as respostas de outros colegas do jeito deles" ou "é uma importante ferramenta pois, posso discutir, concordar, discordar de uma forma dinâmica, do meu jeito, sabendo de imediato o resultado do meu posicionamento diante da situação".

- Alunos que gostaram por motivos ligados à aprendizagem (útil para a aprendizagem): dois alunos (20\%), conforme comentário em destaque: "conseguir ver vários pensamentos diferentes, isso nos abre mais a mente. O fórum ajuda-nos a interpretar mais a questão das dificuldade de gerenciar um projeto (referencia ao conteúdo da questão). Com isso gostei do fórum".

- Não responderam: um aluno (10\%).

Já no GC foi realizado o questionamento: "o que você pensa sobre a ferramenta fórum?"Neste caso, a proposta era apenas de verificar se os alunos gostam do Fórum como opção para realizar a avaliação continuada e 
colaborativa, uma vez que o GC não sabia que o GE estava tendo acesso à ferramenta com implementações diferenciadas das habituais. Os alunos se posicionaram da seguinte maneira:

- Gostam do fórum e o entendem como opção para interagir com colegas e aprender de forma colaborativa, como seguem comentários: sete alunos (70\%), "é muito interessante, você fica sabendo da opinião dos colegas, é uma forma de estudar, pesquisar, ficar interado" ou "excelente ferramenta discutir os assuntos, colocar em dia discussões e duvidas sobre o assunto".

- Não gostam do fórum: dois alunos (20\%) por o entenderem como desnecessário e/ou dispensável, conforme comentário: "acho que no nosso curso não acrescentou em nada."

- Não responderam ao questionamento: um aluno (10\%).

\subsection{4 -Experimento 4_CH/CT: Análise Geral dos Resultados}

Partindo dos resultados obtidos no pré-teste, no teste e no pós-teste, tanto dos alunos de $\mathrm{CH}$, quanto dos alunos do curso de $\mathrm{CT}$, percebeu-se que oferecer opções para participação no fórum pode ser uma estratégia interessante para o processo de aprendizagem, dadas algumas observações relevantes.

Embora em ambos os experimentos ( $\mathrm{CH}$ : $95,8 \%$ e $\mathrm{CT}$ : $70 \%)$ a maioria tenha optado pela escrita, opção habitual de participação, eles mesmos reconheceram a importância de se oferecer opções mais adequadas à forma que cada um prefere participar, ainda com mais ênfase nas CT, os alunos relataram que pessoas que eventualmente tenham dificuldades para expressar ideias em textos escritos, poderiam fazer de outra forma: falando ou gravando com imagem e som. Isso se confirmou no pós-teste de ambos os grupos testados, nos quais $83,6 \%$ dos alunos do $\mathrm{GE}$ da $\mathrm{CH}$ e $90 \%$ dos alunos das $\mathrm{CT}$ acreditam que, por motivos ligados à aprendizagem e/ou pessoais, podem contribuir para a melhoria da aprendizagem de cada aluno e, por conseguinte, do grupo. Ademais, alguns alunos relataram espontaneamente que, se estivessem no ambiente onde habitualmente participam do fórum (longe dos demais colegas e do ambiente da sala de aula), ficariam mais à vontade para 
utilizar as opções de som e/ou gravação com web cam). Assim, recomenda-se, em futuros trabalhos, a realização de experimentos à distância.

Além dos relatos obtidos no pós-teste, a comparação do pré-teste com o resultado do testeratifica que os alunos que tiveram opções de escolha para participação no fórum demonstraram índices maiores de Autoeficácia para a Aprendizagem (item 6 e 9 no GE da $\mathrm{CH}$ e dos itens 3, 6 e 9 no GE das CT), de Motivação extrínseca por introjeção e Motivação extrínseca por identificação no GE das $\mathrm{CH}$, e na Motivação intrínseca para realização no GE da CT. Em síntese, os alunos que tiveram a oportunidade de optar pela forma de como participaria do fórum demonstraram maiores índices de Autoeficácia para a Aprendizagem (os alunos com índices melhores de Autoeficácia acreditam que podem realizar determinada tarefa com mais sucesso, assim, tendem a se sentirem mais capazes de enfrentá-la e, em geral, alcançam de forma eficiente e eficaz seus objetivos - SHUNCK, 1989) e de Motivação extrínseca (impulso para realização baseada em comportamento modificado por meio de técnicas de condicionamento - BERGAMINI, 1997). Já os alunos que utilizaram a ferramenta habitual (GC), em ambos os experimentos ( $\mathrm{CH}$ e $\mathrm{CT}$ ), com a possibilidade única de escrita, não demonstraram quaisquer alterações.

Além disso, a comparação entre os GCs e os GEsapontaram alterações na Motivação extrínseca por introjeção, no $\mathrm{GE}$ da $\mathrm{CH}$ e de Autoeficácia para a Aprendizagemno GE das CT. Tais resultadosevidenciam o potencial da proposta didática implementada para melhoria dos índices de autoeficácia e de Motivação para a aprendizagem, levando-nos a indicá-la como viável para aplicação no Fórum a serem utilizados em cursos superiores que se utilizam da modalidade EAD. 


\section{Capítulo 9 - Considerações Finais}

Esta pesquisa voltou-se, dentre outras, para a questão da busca pela ampliação dos índices de Motivação e da Autoeficácia para a Aprendizagem, variáveis que, junto às demais, são fortemente responsáveis pela sustentação do esforço e dedicação dos alunos inscritos em cursos EAD, por meio da aplicação dos princípios I e II do DU para a Aprendizagem no material didático, a qual foi efetivada por meio da aplicação de quatro propostas didáticas. Vale salientar o viés inclusivo, no sentido amplo, da proposta do DU para a Aprendizagem que busca agregar, ao máximo possível, as especificidades, não de um grupo grande, mas da totalidade dos alunos que buscam ou podem vir a se inscrever naEducação Superior EAD.

Salienta-se que a pesquisa voltou-se para um tema de relevância, que vem sendo pesquisado com mais ênfase nas últimas duas décadas em países como Estados Unidos, Inglaterra e Canadá e que também tem sido objeto de estudo de pesquisadores e profissionais brasileiros, especialmente por tratar de duas questões de grande importância: a acessibilidade e o sucesso da aprendizagem dos alunos daEducação Superior, que o cursam, no todo ou em partes, na modalidade de EAD. Nesse ensejo, a acessibilidade foi lembrada e ressaltada sua importância; contudo, a atenção foi voltada de forma majoritária para o sucesso da aprendizagem, o qual depende, dentre outros aspectos, dos índices de Motivação e Autoeficácia para a Aprendizagem apresentados pelos discentes.

A proposta de explorar e entender a Educação Superior no Brasil, sua CF, regulamentação, evolução histórica, tendências e perfectivas, seguindo de uma contextualização sobre a modalidade de EAD no Brasil, seu potencial para democratização do ensino, a forma como está concebida, as teorias que oferecem respaldo teórico-científico para a prática, bem como a compreensão do papel e da importância que o material didático assume neste contexto, além do estudo das questões práticas de sua concepção e processos de produção, foi de fundamental importância para escolha das propostas didáticas mais adequadas ao público-alvo e para a compreensão de como o DU para a Aprendizagem poderia oferecer efetivas contribuições neste contexto. 
Já a investigação do DU para Aprendizagem culminou em uma discussão sobre suas limitações e potenciais para incorporação no processo de editoração dos materiais didáticos e para a compreensão sobre as contribuições que essa ideia pode proporcionar no processo de ensinoaprendizagem. Assim, a atenção voltou-se para os conceitos de Motivação e Autoeficácia para a Aprendizagem, assim como para algumas das variáveis que influenciam no sucesso do processo de aprendizagem.

A pesquisa realizada, no que concerne ao teste do material didático com as inserções de estratégias pedagógicas, neste caso referindo-se especificamente às quatro propostas didáticas constantes neste trabalho (oferecer opções para leitura ou audição do conteúdo - com vozes feminina ou masculina; oferecer possibilidade de controle da velocidade de expectação da videoaula; oferecer possibilidade de videoaula com recursos áudio visuais ou com legenda para expectação e possibilitar participação no fórum com possibilidades de escolher entre escrever, falar ou gravar com imagem e áudio), evidenciou que os estudantes que têm acesso a um recurso didático autoadaptável se mostram mais motivados (em algumas de suas múltiplas dimensões), em alguns casos, menos desmotivados e com crenças mais positivas de autoeficácia. Ratifica-se que os inúmeros benefícios possibilitados pela incorporação de propostas didáticas pautadas no DU para a Aprendizagem no material didático se assemelharam aos de outros trabalhos apontados na literatura, como no caso de estudos realizados pelo Center for AppliedSpecial Technology. Ademais, dados da pesquisa corroboram que os resultados dos testes da incorporação do DU no material didático demonstram potencial para permitir ainda a inclusão efetiva de alunos com diferentes deficiências e/ou necessidades especiais (O'NEILL; DALTON, 2002; CAST, 2001; WAKEFIELD, 2012).

Os procedimentos de implementação das propostas didáticas demonstraram, ainda, dadas algumas ressalvas (exemplo: a narração do texto preferencialmente pela voz humana fica mais agradável; contudo, isso não descarta a possibilidade do uso de softwares de conversão do texto em áudio, o que possibilita e diminui consideravelmente os custos de produção), que as propostas podem ser implementadas em grande escala, dentro de princípios de sustentabilidade social, ecológico, econômico, espacial e cultural, o que faz do 
DU para a Aprendizagem um projeto possível de ser implementado em recursos didáticos (BRASIL, 2010; ROMANINI, 2007; GIANNETTI; ALMEIDA, 2007; ALMEIDA, 2002).

A metodologia proposta e as técnicas estatísticas utilizadas no trabalho permitiram confirmar e/ou refutar as hipóteses da pesquisa, com base nos resultados obtidos no pré-teste, em comparação com o teste, na comparação entre os GCs e GEs e na confirmação possibilitada pelo pós-teste, sendo que este último possibilitou um viés qualitativo.

A primeira hipótese relacionava-se à possibilidade de cada uma das propostas didáticas empregadas no material didático e em um momento específico de avaliação (avaliação continuada colaborativa), realizadas com base nos princípios do DU para a Aprendizagem, demonstrarem potencial para ampliar os índices de Autoeficácia para a Aprendizagem dos discentes, identificada nas seguintes proporções:

- PD1_DU1, PD2_DU1 e PD4_DU2-CT: a hipótese foi confirmada na comparação dos índices de Autoeficácia para a Aprendizagem apresentados pelos alunos do GE em relação aos índices dos alunos do GC. Foi ratificada na comparação dos índices prévios dos alunos do GEcom os índices aferidos após o contato com o material didático, o que não se repetiu nos alunos do GC e, finalmente, a proposição foi reconfirmada no pós-teste.

- PD3_DU1 e PD4_DU2-CH: na comparação dos índices de Autoeficácia para a Aprendizagem apresentados pelos alunos do GE em comparação aos alunos do GC, a hipótese não se confirmou. Contudo, ao compararmos os índices prévios dos alunos do GE, com os aferidos após o contato do material didático, a hipótese se confirmou, sugerindo que os alunos do GE podem ter iniciado o experimento com índices menores de Autoeficácia para a Aprendizagem e se beneficiaram da implementação das propostas didáticas em questão para chegarem ao final do experimento com índices estatisticamente semelhantes aos do GC. Finalmente, a proposição foi corroborada no pós-teste com a aprovação de boa parte da amostra pertencente ao GE, dentre outros, por motivos ligados à aprendizagem. 
A H01 foi, portanto, confirmada nas quatro propostas didáticas, com maiores índices nos experimento com as propostas didáticas 1, 2 e 4 nas CT e menor ênfase com as propostas 3 e 4 nas $\mathrm{CH}$.

A segunda hipótese de pesquisa voltou-se para a possibilidade de cada uma das propostas didáticas no material didáticoe em um momento específico de avaliação (avaliação continuada colaborativa), realizadas com base nos princípios I e II do DU para a Aprendizagem, demonstrarem potencial para ampliar os índices de Motivação intrínseca e extrínseca dos discentes, como observa-se:

- PD2_DU1, PD3_DU1 e PD4_DU2-CH: a hipótese foi confirmada na comparação dos índices de Motivação extrínseca e intrínseca, com ênfase para a extrínseca, apresentados pelos alunos do GE em relação aos índices dos alunos do GC. Foi ratificada na comparação dos índices prévios dos alunos do GEcom os índices aferidos após o contato com o material didático, o que não se repetiu nos alunos do $\mathrm{GC}$ e, finalmente, a proposição foi reconfirmada no pós-teste, com a aceitação de uma parcela considerável da amostra, por motivos pessoais, da proposta didática implementada.

- PD4_DU2-CT: na comparação dos índices de Motivação extrínseca e intrínseca, com ênfase à extrínseca, apresentados pelos alunos do GE em comparação aos alunos do GC, a hipótese não se confirmou. Contudo, ao compararmos os índices prévios dos alunos do GE, com os aferidos após o contato do material didático, a hipótese se confirmou, sugerindo que os alunos do GE podem ter iniciado o experimento com índices menores de Motivação e se beneficiaram da implementação das propostas didáticas em questão para chegarem ao final do experimento com índices estatisticamente semelhantes aos do GC. Finalmente, a proposição foi corroborada no pós-teste com a aprovação de boa parte da amostra pertencente ao GE, dentre outros, por motivos pessoais.

- PD1_DU1:hipótese não confirmada na comparação dos índices de Motivação extrínseca e intrínseca apresentados pelos alunos do GE em comparação aos alunos do GC e não confirmada na comparação 
dos índices do aluno com ele mesmo após o contato com o material didático, nos levando a refutá-la em sua totalidade.

Verifica-se um aumento geral de índices de Motivação extrínseca e alguns casos pontuais de aumento da Motivação intrínseca. Dados que se justificam na literatura, uma vez que a Motivação intrínseca, em geral, está mais voltada para questões individuais e internas que necessitam de mais tempo e dependem de fatores pessoais para que sejam efetivamente alteradas. Contudo, o aumento dos índices gerais de Motivação extrínseca com maior ênfase nas propostas didáticas 2,3 e $4 \mathrm{CH}$ e menor na proposta $4 \mathrm{CT}$, apontam para o potencial do DU para a Aprendizagem como agente estimulador da Motivação, confirmandoa hipótese, na forma esperada, dado o contexto do constructo.

Para fechar as hipóteses, a pesquisa voltou-se para o fato de a aplicação de cada uma das propostas didáticas no material didático eem um momento específico de avaliação (avaliação continuada colaborativa), realizadas com base nos princípios do DU para a Aprendizagem, ter potencial para diminuir os índices de desmotivação dos discentes. Neste caso, apenas com a PD2_DU1, observou-se a predominância de índices maiores de Desmotivação entre os alunos que não tiveram acesso àproposta implementada (vídeo com áudio/legenda), apontando para uma confirmação parcial da hipótese (no que se refere ao contexto geral do DU para a Aprendizagem) e indicando a necessidade de futuros trabalhos que poderiam vir a ratificar a confirmação ou o descarte de forma total.

Dentre as contribuições proporcionadas por este trabalho, destacam-se a localização, consulta e interpretação da revisão bibliográfica atualizada, no período de estudo, sobre o objeto da pesquisa e temas correlatos; a escolha e apresentação de algumas propostas didáticas que podem ser incorporadas ao material didático, para que este atenda, em parte, aos princípios do DU para a Aprendizagem; a busca por um material didático que contemple as interações dos usuários para atender a suas necessidades, além de respeitar e desenvolver suas competências, habilidades, estilos e capacidades cognitivas e a avaliação dos índices efetivos de Motivação e Autoeficácia para a Aprendizagem proporcionada por cada uma das propostas implementadas. 
Ademais, destaca-se a importância de continuidade de pesquisas sobre o tema trazendo outras descobertas que venham a beneficiar o processo ensino-prendizagem, dentre as quais, sugere-se:

- a verificação do potencial das propostas didáticas aqui implementadas para o alcance de outras dimensões do processo de ensino-aprendizagem;

- a busca e a mensuração de outras propostas que atendam aos princípios do DU para a Aprendizagem e que possam ser implementadas em recursos didáticos, tornando-os autoadaptáveis às necessidades/preferências dos indivíduos;

- a busca de instrumentos de pesquisa voltados para mensuração, de forma específica, dos benefícios que podem ser proporcionados pela incorporação dos princípios do DU para a Aprendizagem em recursos didáticos, nas várias dimensões que figuram no processo de aprendizagem.

Em síntese, pode-se afirmar que este trabalho é apenas um passo de um estudo que precisa ser continuado e aprofundado em busca de respostas que venham oferecer outras sugestões de implementações em benefício do processo de aprendizagem de todos os alunos. Destaca-se a importância de que as características/preferências pessoais dos alunos sejam observadas, mensuradas e investigadas em busca de fórmulas/estratégias que possibilitem a criação de recursos didáticos que proporcionem maiores condições de alcance do sucesso na aprendizagem para todos, independente de suas características/necessidades/habilidades.

Os resultados dos testes da incorporação do DU no material didático demonstram potencial para permitir a inclusão efetiva de alunos com diferentes deficiências e/ou necessidades especiais. Além disso, com índices maiores de Autoeficácia para a Aprendizagem e de Motivação, acredita-se haverpotencial para possibilitar a diminuição de índices de evasão, especialmente no que se refere aos alunos que abandonam seus cursos (ou que nem o procuram) por motivos de inadequação do modelo às suas necessidades/especificidades, uma vez que permite acomodar uma ampla variedade de preferências, ritmos e capacidades individuais. 
Finalmente, os resultados permitem afirmar que a incorporação dos princípios do DU para a Aprendizagem nos recursos didáticos utilizados na Educação Superior na modalidade EAD mostra-se como uma opção potencialmente viável, sustentável e inclusiva. 


\section{Referências}

ABED - Associação Brasileira de Educação a Distância. Epístola de São Paulo sobre a educação a distância (2006). Disponível em: <http://www.abed.org.br/antiga/htdocs/publicacoes/epistola/epistola_sao_paulo _i.htm>. Acesso em: 10 mar. 2011.

- que é educação a distância. Disponível: <http://www2.abed.org.br/faq.asp?Faq_ID=8>. Acesso em: 5 mar. 2011.

$\begin{array}{llllll}\text { ABNT. } & \text { ABNT NBR } & \mathbf{1 5 . 2 9 0} & \text { (2005). Disponível em: }\end{array}$ <http://portal.mj.gov.br/corde/arquivos/ABNT/NBR15290.pdf>. Acesso em: 5 mar. 2011.

ABRAEAD. Anuário Brasileiro Estatístico de Educação Aberta a Distância - 2008 (2008). Disponível em: <http://www.abraead.com.br/anuario.html>. Acesso em: 1 maio 2010.

ACESSIBILIDADE. Homepage. Disponível em: <http://www.acessibilidade.org.br/>. Acesso: 13 jun. 2011.

ALAVI, M.; CARLSON. P. A review of MIS research and disciplinary development. Journalof Management Information Systems, Armonk, v. 8, n. 4, p. 45-62, 1992.

ALMEIDA, F. O bom negócio da sustentabilidade. Rio de Janeiro: Nova Fronteira, 2002.

ALONSO, J. L. N. et al.Validación de la Escala de Motivación Educativa (EME) enParaguay. Revista Interamericana de Psicologíal InteramericanJournalofPsychology, v.40, n.2, p.391-398, 2006.

AMARAL, D. P. Paradigmas da inclusão: uma introdução. In: SOBRINHO, F. P N. (Org.).Inclusão educacional: pesquisa e interfaces (p.11-20). Rio de Janeiro: Livre Expressão, 2003.

Disponível

L. A.Propondo uma política da USP referida à deficiência.

<http://usplegal.saci.org.br/quem/Propondo_uma_Pol\%C3\%ADtica_da_USP_R eferida_\%C3\%A0_Defici\%C3\%AAncia.htm>. Acessoem: 11 jun. 2011.

ANDERSON, L. W.; KRATHWOHL D. R. (eds.). A taxonomy for learning, teaching, and assessing: a revision of bloom's taxonomy of educational objectives. New York: Longman, 2001.

ANDRADE, Maria Margarida de. Introdução à metodologia do trabalho científico: elaboração de trabalhos na graduação. 5. ed. São Paulo: Atlas, 2001. 
ARANHA, Maria Lúcia de A. História da educação. 2 ed. São Paulo: Moderna, 1996.

ARETIO, Garcia. Aprender a distância: estudiar em laUned. Madrid: Casa Del Livro, 1998.

AZENHA, M. da G. Construtivismo, de Piaget a Emília Ferreiro. 7 ed. São Paulo: Ática, 2002.

BABBIE, E. Practice of Social Research. 8th Edition. New York: Wadsworth Publishing, 2001.

BANDURA, A. A evolução da teoria social cognitiva. In: BANDURA, A.; AZZI, R. G.; POLYDORO, S. (Orgs.). Teoria social cognitiva, conceitos básicos(p. 15-42). Porto Alegre: Artmed, 2008.

. Guide for constructingselfefficacyscales. Disponível em: $<w w w . d e s . e m o r y . e d u / m f p / S E G u i d e R e v-2005-A E 5 . d o c>$. Acessoem? 21 ago. 2005.

. Human agency in social cognitive theory. American Psychologist 44, p. $1175-1184,1989$.

Perceived self-efficacy in cognitive development and functiong. Educational Psychologist. N. 28(2), p. 117-148, 1993.

Self-efficacy mechanism in human agency. American Psychologist, n. 37, p. 122-147, 1982.

Self-efficacy: the exercise of control. New York: Freeman, 1997.

Social cognitive theory: an agentic perspective. Annual Reviews Psychologist, n. 52(1), p. 2-18, 2001.

Social foundations of thought and action: a social cognitive theory. EnglewoodCliffs: Prentice Hall, 1986.

BAPTISTA, Elizabeth. Metodologia de pesquisa. Petrópolis: Vozes, 1983.

BENÍCIO, Edgard R. Educação e tecnologias: novidades, desafios e formação de professores. Disponível em: <http://www.partes.com.br/educacao/educacaoetecnologia.asp>. Acesso em: 30 set. 2009.

BERGAMINI, Cecília Whitaker.Motivação nas Organizações. $4^{\circ}$ ed. São Paulo: Atlas, 1997. 
BLATTES, R. L. (Org.). Direito à educação: subsídios para a gestão dos sistemasEducacionais - orientações gerais e marcos legais. 2. ed. Brasília: MEC, SEESP,2006.

BORTOLANZA, M. L. Insucesso acadêmico na universidade abordagens psicopedagógicas. Erechim: Edifapes, 2002.

BORUCHOVITCH, E. Conhecendo as crenças sobre inteligência, esforço e sorte de alunos brasileiros em tarefas escolares. Revista Psicologia Reflexão e Crítica, n. 14(3), p. 461-467, 2001.

BRASIL,Casa Civil. Constituição da República Federativa do Brasil de 1988 (1988).

Disponível

em: <http://www.planalto.gov.br/ccivil_03/constituicao/constitui\%C3\%A7ao.htm>. Acesso em 10 jun. 2011.

2002).

Diagnóstico preliminar desenvolvimento social educação (II <http://www.dominiopublico.gov.br/download/texto/me000663.pdf>. Acesso em: 10 jun. 2011.

, Casa Civil. Decreto n. 5773 de 9 de maio de 2006 (2006). Disponível em:<http://www.planalto.gov.br/ccivil_03/_ato20042006/2006/decreto/d5773.htm>. Acesso em: 12 nov. 2012.

Decreto n. 5.622, de 19 de dezembro de 2005 (2005). Disponível em: $<$ http://www.planalto.gov.br/ccivil_03/_Ato20042006/2005/Decreto/D5622.htm>. Acesso em: 1 dez. 2010.

,MINISTÉRIO DA EDUCAÇÃO. Homepage. $<$ http://portal.mec.gov.br/index.php?option=com_content\&view=article\&id=289\& Itemid=356>. Acesso em 2 out. 2009.

. Lei de Diretrizes e Bases da Educação Nacional (1994). Disponível em: <http://portal.mec.gov.br/arquivos/pdf/ldb.pdf>. Acesso em 10 jun. 2011.

. Módulo III - Livro de Estudo 2 - Unidade 1 (2006). Disponível em:<http://portal.mec.gov.br/seb/arquivos/pdf/Educinf/mod_iii_vol2unid1.pdf>. Acesso em: 1 mar. 2011.

(2007).

Referenciais de qualidade para Educação Superior a distância <http://portal.mec.gov.br/seed/arquivos/pdf/legislacao/refead1.pdf>. Acesso em 10 jun. 2011.

MINISTÉRIO DO MEIO AMBIENTE. Homepage. Disponível em: <http://www.mma.gov.br>. Acessoem: 19 set. 2010. 
BROPHY, J. Conceptualizing student motivation. Educational Psychologist, n. 18, p. 200-215, 1983.

BRUNNER, José Joaquim. Educação no encontro com as novas tecnologias. IN: TEDESCO, J. C.; CORRÊA, Juliane (Org.). Educação a distância: orientações metodológicas. Porto Alegre: Artmed, 2007.

. Educação no encontro com as novas tecnologias. In TEDESCO, Juan Carlos (Org.). Educação e novas tecnologias. Esperançasouincertezas? São Paulo, Cortez, p. 20, 2004.

BURGSTAHLER, S. Access to Internet-based instruction for people with disabilities. In: PETRIDES, L. A. (Ed.) Case studies on information technology in higher education(p. 76-88). Hershey: IRM Press, 2000.

. Universal design of instruction: from principles to practice. In: Universal design in higher education: From principles to practice. Boston: Harvard Education Press (p. 23-44), 2008. JournalofPostsecondaryEducationandDisability, n. 21(3), p. 151-174, 2009.

CALIXTO, Aldeci; OLIVEIRA, Elsa G.; OLIVEIRA, Gilca dos S. V. Enfrentar as incertezas: alternativas didáticas em ambientes virtuais. Disponível em: <http://www.abed.org.br/congresso2005/por/pdf/031tcc3.pdf>. Acesso em: 15 out. 2009.

CAMPOS, Iberê M. Frase. Sine loco, s/d. (no prelo)

CARRION, W. Design para webdesigners - princípios dodesign para web. Rio de Janeiro: Brasport, 2008.

CARVALHO, A. A. et al.Integração de podcasts no ensino universitário: reações dos alunos. Prisma.com n. 6 (ISSN: 1646 - 3153). Disponível em: <http://revistas.ua.pt/index.php/prismacom/article/view/664/pdf>. Acesso em: 14 ago. 2012.

, RositaEdler. Removendo barreiras para a aprendizagem. Porto Alegre: Mediação, 2003.

CAST. What is Universal Design for Learning? Disponível em: <http://www.cast.org/udl/index.html>. Acesso em: 17 jul. 2011.

CAVALCANTI, C. M. C. Tendências e possibilidades da educação a distância como modalidade de ensino. Disponível em: <http://www.unisa.br/unisadigital/tendencias_possibilidades_ead.pdf>.

Acessoem: 10 jun. 2011. 
CENA, Johanna AND. Bridging gaps between cultures, classrooms and schools: a close look attn online collaborative learning (2000). Disponível em: <http://www.ifets.ieee.org/periodical/vol.3 2000/d01.html>. Acesso em: 1 ago. 2011.

CENTRO DE REFERÊNCIAL DE EDUCAÇÃO. Orientações pedagógicas. Disponível em: <http://crv.educacao.mg.gov.br/sistema_crv/INDEX.ASP?ID_OBJETO=23967\&I D_PAl=23967\&AREA=AREA\&P=T\&id_projeto=27>. Acesso em: 10 abr. 2011.

CNE - Conselho Nacional de Educação. Parecer Homologado: Despacho do Ministro, publicado no Diário Oficial da União de 31/10/2002(2002).Disponível em: <http://portal.mec.gov.br/cne/arquivos/pdf/2002/pces254_02.pdf> Acesso em: 12nov. 2012.

$\overline{\text { Oficial }} \begin{gathered}\text { Parecer Homologado: Despacho do Ministro, publicado no Diário } \\ \text { da União de 21/05/2007 }\end{gathered}$ <http://portal.mec.gov.br/cne/arquivos/pdf/pces263_06.pdf> Acesso em: 12nov. 2012.

CORRÊA, A. G. D. Et al. Avaliação de aceitabilidade de um computador portátil de baixo custo por criança. In: XVII Simpósio Brasileiro de Informática na Educação - SBIE, 8 a 10 de novembro de 2006. Anais Digital..., Brasília, 2006.

COSTA, F. A. Elementos para reflexão sobre a integração das TIC na Educação. In: MACHADO, Lourdes Marcelino; FERREIRA, NauraSyriaCarapeto (Orgs.). Política e gestão da educação - dois olhares. São Paulo: DP\&A Editora, 2002.

CRESPO, Victor. Ganhar Bolonha, ganhar o futuro: o Ensino Superior no espaço europeu, Lisboa: Gradiva, 2003.

CUNHA, Luiz Antônio. Ensino Superior e Universidade no Brasil. In: LOPES, E. M. T. et al.500 anos de educação no Brasil. Belo Horizonte: Autêntica, 2000.

, T.M. O uso de filmes legendados e do ensino comunicativo de línguas no desenvolvimento da proficiência oral. Dissertação (Mestrado em Lingüística Aplicada), Universidade Estadual do Ceará, Fortaleza, 2007.

DE SÁ, A. P. Inteligência, reações à frustração e auto-eficácia acadêmica percebida: um estudo preliminar multicorrelacionado. 224f. Dissertação de Mestrado em Psicologia Social, Universidade Gama Filho, Rio de Janeiro, 2002.

Propriedades psicométricas de uma escala de auto-eficácia acadêmica e suas relações com desempenho estudantil e interação social. RevistaBrasileira de TerapiasCognitivas, 2(2), p.61-72, 2006. 
DECI, E.L.; VALLERAND, R.J., PELLETIER, L.G.; RYAN, R.M.Motivation in education: the self-determination perspective. The Educational Psychologist, n. 26, p. 325-346, 1991.

; HALL, T. E. Universal Design for Learning: implications for large-scale assessment. IDA Perspectives, n. 27(4), p. 22-25, 2001.

DRUCKER, P.F. Uma era de descontinuidade. Rio de janeiro: Zahar,1974.

DUARTE, S. S. et al.Produção de vídeo didático sobre cesariana em égua na disciplina de obstetrícia veterinária. Jepex 2009. Disponível em: $<$ http://www.eventosufrpe.com.br/eventosufrpe/jepex2009/cd/resumos/R03251.pdf>. Acesso em: 14 ago. 2012.

FALCAO, D. F.; ROSA, V.V. Um estudo sobre a Motivação dos universitários dos cursos de administração (2008). Disponível em: <http://pt.scribd.com/doc/55377425/EPQA789>. Acesso em: 13 jun. 2011.

FERNÁNDEZ, A. O saber em jogo: a psicopedagogia propiciando autorias de pensamentos. Porto Alegre, Artmed Editora, 2001.

FERREIRA, Marcelo. Ensino a distância pela Internet (1999). Disponível em: <http://www.geocities/WallStreet/7939>. Acesso em: 1 out. 2010.

, N.S.C. Gestão democrática da educação: ressignificando

FLETCHER, V. Design universal: design para o século 21. Sine loco: Griffith University, 2002.

FONSECA, V. da. Introdução às dificuldades de aprendizagem. Porto alegre: Artes Médicas, 1995.

FRAGA, Giulia A. R. et. al. Educação on-line: interatividade e aprendizagem colaborativa.

$<$ http://www.comunidadesvirtuais.pro.br/gptec/arquivos/a_marlene.pdf $>$. Acesso em: 13 out. 2009.

FUNDAÇÃO BIBLIOTECA NACIONAL. Homepage. Disponível em: $<$ http://www.bn.br/portal/>. Acesso em: 11 jun. 2011.

GADOTTI, Moacir. Pedagogia da práxis. 2. ed.São Paulo: Cortez, 1998.

GALBRAITH, Jonh Kenneth. A sociedade justa: uma perspectiva humana. Rio de Janeiro: Campus, 1976.

GARRIDO, I. Motivacion, emocion y accion educativa. In: MAYOR, L.;TORTOSA, F. (eds.). Âmbitos de aplicacion de la psicologia motivacional(p. 284-343). Bilbao: Desclee de Brower, 1990. 
GIANNETTI, B. F.; ALMEIDA, C. M. B. V. Ecologia Industrial: conceitos, ferramentas e aplicações. São Paulo: Editora Edgard Blücher,2006.

GIL, Antonio Carlos. Como elaborar projetos de pesquisa. São Paulo: Atlas, 1991.

GLAT, R.; FERNANDES, E. M. Da educação segregada à educação inclusiva: umabreve reflexão sobre os paradigmas educacionais no contexto da educação especialbrasileira. Revista inclusão: MEC/SEESP, vol. 1, n. 1, p. 35-39, 2005.

GLAT, R.; NOGUEIRA, M. L. de L. Políticas educacionais e a formação de professorespara a educação inclusiva no Brasil. Revista Integração, vol. 24, ano 14, p.22-27, Brasília: MEC/SEESP, 2002.

GOMES, F. W. B. G. Os textos na tela da TV: o papel da associação entre sons, imagens e legendas noensino de línguas. Caminhos em linguística aplicada, v. 2, n. 1, p.53-66, 2010.

, L. T.et al.Inclusão e produção de audiotextos na construção de conhecimento e aprendizagem dos cegos de Santa Maria - RS.Disponível em:

<http://www.unl.edu.ar/iberoextension/dvd/archivos/ponencias/mesa3/inclusaoe-producao-de-audio.pdf>. Acessoem: 14 ago. 2012.

GOTTFRIED, A. E. Academic intrinsic motivation in elementary and junior high school students.Journal of Educational Psychology, n. 88(3), p. 525-538, 1990.

E. Academic intrinsic motivation in elementary and junior high school students. Journal of Educational Psychology, n. 77(6), p. 631-645, 1985.

GOUVÊA, Guaracira; OLIVEIRA, Carmen Irene. Educação a distância na formação de professores: viabilidades, potencialidades e limites. Rio de Janeiro: Vieira e Lent, 2006.

GREGIO, Bernardete Maria Andreazza. A informática na educação: as representações sociais e o grande desafio do professor frente ao novo paradigma educacional. v.2, n. 6, mar. 2004. Disponível em:<http://pead.ucpel.tche.br/revistas/index.php/colabora/article/viewFile/43/39 >. Acesso em: 7 set. 2010.

GUARANYS, L. R. dos. Castro, C. M. O ensino por correspondência: uma estratégia de desenvolvimento educacional no Brasil. Brasília: IPEA, 1979.

GUTIERREZ, Francisco; PRIETO, Daniel. A mediação Pedagógica. In.: A mediação pedagógica: educação à distância alternativa. Tradução de Edilberto M. Sena e Carlos Eduardo Cortés. Campinas: Papirus, 1994.

HARVEY, M. S. S. O uso didático do gênero filme legendado na aprendizagem de leitura de textos do gênero jornalístico/noticioso. 
Dissertação (Mestrado em Linguística Aplicada). Universidade Estadual do Ceará: Fortaleza, 2009.

HAWKRIDGE, D. New information technology in education. Baltimore: The Johns Hopkins University Press, 1983.

HENRY, Shawn Lawton.Essential components of web accessibility. W3C/WAI - World WideWeb consortium / web accessibility initiative (2006). Disponível em: <http://www.w3.org/WAl/intro/components.php>. Acesso em 2 jun. 2011.

HILSDORF, Maria Lúcia S. História da Educação brasileira: leituras. São Paulo: Thomson, 2002.

HOLMBERG, Börje. Educación a distancia: situación y perspectivas. Buenos Aires: Editorial Kapeluz, 1985.

HRICKO, M. Desinging accessible web-based courses. Indian Journal of Open Learning, n. 9 (3), p. 393-401, 2002.

HUGHES, K.R., REDFIELD, D. L.; MARTRAY, C. R.The children's academic motivationinventory: a research note on psychometric propertiesmeasurement and evaluation in counselingand development,1989, v.22.

IBGE - Instituto Brasileiro de Geografia e Estatística. Homepage. Disponível em: <http://www.ibge.gov.br/home/>. Acesso em: 9 abr. 2010.

IBOPE -INSTITUTO BRASILEIRO DE PESQUISA. Estatística do ensino no Brasil (2000). Disponível em: <http://www.ibope.com.br>. Acesso em: 1 out. 2010.

IPEA. Brasil em esenvolvimento. <http://www.ipea.gov.br/bd/pdf/Livro_BrasilDesenvEN_Vol03.pdf>. Acessoem: 10 jun. 2011.

JOO, Y., BONG, M., \& CHOI, H. Self-efficacy for self-regulated learning, academic selfefficacy, and Internet self-efficacy in Web-based instruction. Educational Technology Research and Development, n. 48 (2), p. 5-17, 2000.

KEEGAN, D. Foundations of distance education. 2. ed. Londres: Routledge, 1991.

; HOLMBERG, B., MOORE, M. G., et al.Distance education International perspectives. London: Routlege, 1991.

KENSKI, Vani M. Tecnologias e ensino presencial e a distância. São Paulo: Papirus, 2006. 
$\mathrm{KIM}, \mathrm{Y}$. H. A learning approach to precision speed control of servomotors and its application to a VCR. Control Systems Technology, v. 7, issue 4, p. 466477, jul. 1999.

KOTTER, P. John. A escolha de estratégias para mudanças. São Paulo: Nova Cultural, 1997.

LAKATOS, E. M.; MARCONI, M. A. Fundamentos de metodologia científica. 3.ed. São Paulo: Atlas, 1991.

LEE, Stuart; GROVES, Paul; STEPHENS, Christopher. Internet teaching: existing tools \& projects for on-line teaching (1996). Disponível em: <http://info.ox.ac.uk/jtap/reports/teaching>. Acessoem: 1 out. 2010.

LENS, W. Motivation and learning. In: HUSEN, T. POSTLETHWAITE, T. N. (Orgs.). The international encyclopedia of education, vol. 7, p. 3936-3942. United States: Pergamon, 1994.

LEPPER, M. R.et al.Intrinsicand extrinsic motivation: a developmentalperspective. Developmental psychopathology: Perspectives on adjustment,risk, and disorder. Cambridge: UniversityPress (p. 23-50), 1997.

LEVINE, T. et al.Computer use, confidence, attitudes, and knowledge: a causal analysis. computers in human behavior. Journal of Personality and Social Psychology, n. 14(1), p. 815-822, 1998.

LÉVY, Pierre. Educação e cybercultura. Disponível em: <http://www.sescsp.org.br/sesc/images/upload/conferencias/29.rtf>. Acesso em 20 out. 2009.

LEWIN, Kurt. Teoria do campo em ciência social. SãoPaulo: Pioneira, 1965.

LITTO, F. $15^{\circ}$ Ciaed - Congresso Internacional Abed de Educação a Distância: a procura de inovações no processo ensino-aprendizagem em EAD (2009). Disponível em: <http://www.abed.org.br/congresso2009/>. Acesso em: 1 dez. 2010.

LUCHESI, C. C. Democratização da educação: ensino à distância como alternativa. Tecnologia educacional, Rio de Janeiro, ABT, n. 89/90/91, jul/dez. 1989.

et al.Fazer universidade: uma proposta metodológica. 5. ed. São Paulo, Cortez, 1989.

MACHADO, Liliana Dias; MACHADO, Elian de Castro. O papel da tutoria em ambientes de EaD. Disponível em: <http://www.abed.org.br/congresso2004/por/htm/022-TC-A2.htm>. Acesso em 13 out. 2009. 
MANTOAN, M. T. E. A hora da virada. In: Revista de Educação Especial Inclusão, n. 1, p. 24-28, Brasília, 2005.

MARCHESI, Álvaro; GIL, Carlos Hernández. Fracasso escolar: umaperspectiva multicultural. Porto Alegre: Artmed, 2004.

MARTINS, Onilza Borges. Experiências de educação a distância no Brasil. Disponível em: $<$ http://www.cipead.ufpr.br/conteudo/artigos/experiencia_ead.pdf>. Acesso em 05 out. 2009a.

MARTINS, Onilza Borges. Os caminhos da EAD no Brasil. Disponível em: $<$ www2. pucpr.br/reol/index.php/DIALOGO?dd1=2012\&dd99=pdf $>$. Acessoem 20 out. $2009 \mathrm{~b}$.

MASON, Robin. Models of on-line courses. Magazine, v. 2, Oct. 1998.

MCKNIGHT, C.; RICHARDSON, J.; DILLON, A. The authoring ofhypertext documents. In: MCALEESE, R. (ed.). Hypertext: Theory into practice (p.138147).Norwood: Ablex Publishing Corporation, 1989.

MEDEIROS, Marilú F.et al.Ambientes virtuais de aprendizagem: o desafio de novos traçados na produção do conhecimento como criação. Disponivel em: <http://lsm.dei.uc.pt/ribie/docfiles/txt200372918524paper314.pdf $>$. Acessoem: 10 out. 2009.

MEECE, J. L. The classroom context and students' motivational goals. In: MAHER, M. L. A.; PINTRICH, P. R. (eds.). Advances in motional and achievement, p. 261-285.Greenwich: JAI Press, 1991. v. 7.

MELO, V. G. et al.Produção de audiotextos para educação inclusiva. Anais $25^{a} \quad J A l . D i s p o n i v e l \quad e m:$ <http://portal.ufsm.br/jai2010/anais/trabalhos/trabalho_1041201522.htm>. Acesso em: 14 ago. 2012.

MENEZES, P. E. Universidade: ação e reflexão. Fortaleza: UFC, 1983.

MEYER, A.; ROSE, D.H. Learning to read in the computer age. Cambridge, MA: Brookline Books, 1998.

MILLS, S. Learning about Learning objects with Learning Objects. In: League for Innovations CIT Conference 2002, Long Beach. California: [s.n.], 2002.

MITCHELLJR., J.V.Interrelationships and predictive efficacy for indices of intrinsic andextrinsic, and self-assessed motivation for learning. J. Res. Develop. Educ., n. 25, p. 149-155, 1992. 
1998.

R.; MYLES, F. Second language learning theories. London: Arnold,

MONTEIRO, A. V.; COSENTINO, Aldo; MERLIN, L. Tendências pedagógicas e ensino à distância: conjeturas em direção a uma universidade colaborativa. In: A gestãoacadêmicaem debate. Florianópolis: Insular, 2000.

MOORE, M.Distance education: a leaner's system. Lifelong learning: an omnibus of practice and research, v. 12, n.8, p.8-11, 1989.

; KEARSLEY, G. Educação a distância: uma visão integrada. São Paulo: Cengage Learning, 2007.

MORAN, J. M. Avaliação do Ensino Superior a distancia no Brasil. Disponível em: < http://www.eca.usp.br/prof/moran/avaliacao.htm>. Acesso em: 10 out. $2009 a$.

_. 0 que é educação a distância. Disponível em: <http://www.eca.usp.br/prof/moran/dist.htm>. Acesso em: 2 fev. 2011.

- que é educação à distância. Disponível em: <www.eca.usp.br/prof/moran/dist.htm>. Acessoem: 10 out. 2009b.

MOSCATI, S. R. et al.Use of audio on e-learning. $9^{\circ}$ CONTECSI Internacional Conference on Information Systems and Techonology Management. Disponível em: <http://www.tecsi.fea.usp.br/envio/contecsi/index.php/envio/article/view/9CONT ECSI2012\%2FRF-640>. Acessoem: 14 ago. 2012.

MOUSAVI, S.; LOW, R.; SWELLER, J. Reducing cognitive load by mixing auditory and visual presentation modes. Journal of Educational Psychology, 87(2), 1995.

MURPHY, E. J. Motivação e emoção. Rio de Janeiro: Guanabara-Koogan, 1986.

P. K.; ALEXANDER, P. A. A motivated exploration of motivation terminology. Contemporary Educational Psychology, n. 25, p. 3-53, 2000.

NCSU-CAST. Universal design for learning guidelines 1.0. Wakefield: CAST. Retrieved, jul. 2008.

NIELSEN, J.Hypertext \& hypermedia. Boston: Academic Press, 1990.

NORMAN, G.R.; STREINER, D.I.Biostatistics: the bare essentials. St. Louis: Mosby, 1994.

NOVA, F. Gerações de EAD marcadas por diferentes tecnologias. E-learning Brasil (2004).

Disponível

em: 
<http://portal.webaula.com.br/noticia.aspx?sm=noticias\&codnoticia=15>. Acesso em: 1 dez. 2010.

NUNES, I. B.Educação a distância e o mundo do trabalho.Tecnologia Educacional. Rio de Janeiro: ABT, v. 21 (107), jul./ago., 1992.

I. B. Noções de educação a distância. Disponível em: <http://w.rautu.unicamp.br/nou-rau/ead/document/?code=3>. Acesso em: 3 . outubro. 2010.

OLIVEIRA, Eloiza Gomes de; VILLARDI, Raquel. Tecnologia na educação uma perspectiva sociointeracionista. Rio de Janeiro: Dunya, 2005.

F. K. O vídeo pela Internet como ferramenta educacional. Disponível em: <http://www.inf.pucminas.br/sbc2010/anais/pdf/wie/sp01_05.pdf>. Acesso em: 14 ago. 2012.

ONU - Organização das Nações Unidas. Disponível em: <http://www.onubrasil.org.br/>. Acesso em: 12 jun. 2011.

OPPORTUNITY ACT. Homepage(2008). Disponível em: <http://www2.ed.gov/policy/highered/leg/hea08/index.html>. Acessoem: 12 jun. 2011.

ORNELLA, P.; STÉPHANIE, B. Universal Design for mobile phones: a case study. Montréal: Work-in-Progress. Disponívelem: <http://www.acm.org>. Acessoem: 23 jul. 2007.

PAJARES, F. Current directions in self-efficacy research. In: MAEHR, M.; PINTRICH, P. R. (eds.). Advances in motivation and achievement, v. 10, p. 1-49. Greenwich: JAI Press, 1997.

Self-efficacy beliefs in academic contexts: an outline (2009). Disponível em: <http://www.emory.edu/education/mfp/efftalk/html>.Acessoem: 14 ago. 2012.

PAJARES, F. Self-efficacy beliefs in academic settings. Review of Educational Research, n. 66, p. 543-578, 1996.

; SCHUNK, D. H. Self-beliefs and school success: Self-efficacy, selfconcept, and school achievement. In: RIDING, R.; RAYNER, S. (eds.). Selfperception(p. 239-266). London: Ablex Publishing, 2001.

PALDÊS, Roberto Ávila. O uso da Internet no Ensino Superior: estudo de caso da Universidade de Brasília. Brasília: UNB, 1998.

PARANÁ. Dia-a-dia educação - Inclusão. Disponível em: <http://www.diaadiaeducacao.pr.gov.br/portals/portal/pee/tematicos.pdf?PHPS $E S S I D=2009102710203461>$. Acesso em: 12 jul. 2011. 
PERRENOUD, P. Dez novas competências para ensinar. 3. ed. Tradução de Patrícia Chittoni Ramos. Porto Alegre: Artes médicas Sul, 2000.

PERRY, W. R. A short guidetodistanceeducation. Cambridge: International Extension College, 1995.

PETTERS, O. Learning and teaching in distance education: analyses and interpretations from an international perspective. Kogan Page Ltda., 1973.

PFROMM, S. N. Psicologia da aprendizagem e do ensino. São Paulo: EPU, 1987.

PIAGET, Jean Willian Friz; FRAISSE, Paul. Tratado de Psicologia Experimental: Motivação, emoção e personalidade. Tradução de Agnes Cretella. Rio de Janeiro: Florense, v. 5, 1969.

PIMENTA, S. G. Docência no Ensino Superior. São Paulo, Cortez, 2002.

PINA NEVES, S.; FARIA, L. Auto-eficácia acadêmica e atribuições causais em português e matemática. AnálisePsicológica, XXV (4), 635-652, 2007.

PINTRICH, P. R.; DEGROOT, E. V. Motivational and self-regulated learning components of classroom academic performance.Journal of Educational Psychology, n. 82, p. 33-40, 1990.

; SCHUNK, D. H. Motivation in education - theory, research and applications. New Jersey: Merril Prentice Hall, 2002.

Merrill, 1996.

Motivation in education: Theory, research, and applications. Ohio:

POLYDORO, Soely A. J; GUERREIRO-CASANOVA, Daniela C. Escala de auto-eficácia na formação superior: construção e estudo de validação. Aval. psicol., Porto Alegre, v. 9, n. 2, ago. 2010.

POSSAMAI, F. Breve incursão teórica sobre aprendizagem de adultos. Revista Univille, v. 8, n. 2., 2003.

POZO, Juan Ignácio. Aprendizes e mestres: a cultura da aprendizagem.

PRÓ-INCLUSÃO. Textos sobre inclusão. Disponível em: <http://www.proinclusao.org.br/textos.html>. Acesso em: 12 jun. 2011.

RAMALHO, D. Motivação e Ensino Superior. Disponível em: $<$ http://www.gentedeopiniao.com.br/lerConteudo.php?news=4713>. Acesso em: 12 jun. 2011. 
RAMPELOTTO, E. M. et al.Produção de audiotextos: um movimento para a inclusão. Disponível em: <http://www.unifra.br/eventos/jne2008/Trabalhos/128.pdf>. Acesso em: 14 ago. 2012.

REALE, M. A educação no Brasil. Folha de São Paulo, mar. 2000.

RIBEIRO, D. A universidade necessária. São Paulo: Paz e Terra, 1969.

RICHARDSON, R. J. Pesquisa social: métodos e técnicas. 3. ed. São Paulo: Atlas, 1999.

RITLA. Aula 3: curso Fead - Material disponibilizado no portal da Ritla. Disponível em: <http://uni.ritla.org.br>. Acesso em: 1 out. 2010.

ROESLER, V.; CERON, J. M.; ANDRADE, M. Aulas remotas on-line utilizando transmissão de vídeo: estudo decaso na Informática da Unisinos. XIV Simpósio Brasileiro de Informática na Educação - NCE, Rio de Janeiro: IM/UFRJ, 2003.

ROMANINI, Vinícius. Portal Exame: o valor da sustentabilidade (2007). Disponível em:<http://portalexame.abril.com.br/revista/pme/edicoes/0009/m0133114.html> . Acessado em: 3 mai. 2009.

ROMANO, Roberto. A universidade e o neoliberalismo. In: Caminhos, Belo Horizonte: APUBH, n. 18, 1999.

ROMISZOWSKY, A. J. Psychomotor principles. In: FLEMING, M.; LEVIE, W. H. (Eds.). Instrucional message design. Englewood Cliffs. NJ: Educational Technology, 1993.

ROSE, D. H.;HITCHCOCK, A. The universally designed classroom: accessible curriculum and digital technologies. Harvard Education Press, Cambridge, MA, 2005.

; MEYER, A. A practical reader in Universal Design for Learning. Cambridge: Harvard Education Press, 2006.

.Teaching every student in the digital age: Universal Design for Learning. Alexandria: ASCD, 2002.

A.; HITCHCOCK, C. The universally designed classroom: accessible curriculum and digital technologies. Cambridge: Harvard Education Press, 2005.

S.; MEO, G. Universal design para a aprendizagem. Journal of special education technology, n. 15 (2), p. 56-60, 2000. 
ROSENBERG, N. Por dentro da caixa-preta: tecnologia e economia. Campinas: Unicamp, 2006.

ROSENHOLTZ, S. J.; SIMPSON, C. The formation of ability conceptions: developmental trend or social construction? Review of Educational Research, n. 54, p. 31-63, 1984.

RUMBLE, G.; OLIVEIRA, J. Vocational education at a distance: international perspectives. London: Kogan Page, 1982.

SÁ, I. A auto-regulação da aprendizagem: o papel da auto-eficácia nas transições escolares. Psychologica, 44, 63-76, 2007.

SABA, F. Distance education theory, methodology, and epistemology: a pragmatic paradigm. In: MOORE, M.; ANDERSON, W. (Org.).Handbook of distance education. New Jersey: Lawrence Erlbaum Associates, 2003.

SALERMO, M. Libras como primeira língua dos deficientes auditivos. Disponível em: <http://saci.org.br/?modulo=akemi\&parametro=5473>. Acesso em: 14 ago. 2012.

SAMPIERI, Roberto H.; COLLADO, Carlos F.; LUCIO, Pilar B. Metodologia de Pesquisa. 3. Ed. São Paulo: McGraw Hill, 2006.

SARAIVA, T. Educação a distância no Brasil: lições da história. Em Aberto, Brasília, ano 16, n.70. abr./jun., 1996.

SCHUNK, D. H. Commentary on self-regulation in school contexts. Learning and instruction, n. 15, p. 173-177, Sine loco, 2005.

. Self-efficacy and academic motivation. Educational Psychologist, n. 26, p. 207-231, 1991.

Social-cognitive theory and self-regulated learning. In: ZIMMERMAN, B. J. (eds.). Self-regulated learning and academic achievement: Theory, research and practice (p. 83-110). New York: SpringerVerlag, 1989.

; PAJARES, F. The development of academic self-efficacy. In: WIGFIELD, A.; ECCLES, J. (eds.). Development of achievement motivation(p. 16-31). San Diego: Academic Press, 2002.

.; ZIMMERMAN, B. J. Social origins of self-regulatory competence. Educational Psychologist, n. 32(4), p. 195-208, 1997.

SCOTT, P. The Meanings of Mass Higher Education, Buckingham. Sine Ioco: Open University Press/SRHE, 1995. 
SCOZ, B. Psicopedagogia e realidade escolar: o problema escolar e de aprendizagem. Petrópolis, RJ, Vozes, 1994.

SENAI. Autoinstrução com monitoria. São Paulo: Senai, Divisão de Material Didático, s/d.

SEWART, D.; KEEGAN, D.; HOLMBERG, B. Distance education: internacional perspectives. London: Routledge, 1998.

SHNEIDERMAN, Ben.Designing the user interface: strategies for effective human-computer interaction. 4th Edition. Massachusetts: Addison Wesley, 2004.

Press, 2002.

.Human needs and the new computing technologies. Sine loco: MIT

SOBRAL, D. T. Motivação do aprendiz de medicina:uso da escala de Motivação acadêmica. Psicologia: teoria e pesquisa, v. 19, n. 1, p. 25-31, jan.-abr. 2003.

- Motivação do aprendiz de medicina: uso da escala de Motivação acadêmica. Psic.: Teor. e Pesq.Brasília, v. 19, n. 1, Apr. 2003.

SOUSA, José Vieira de. O Ensino Superior privado no Distrito Federal: uma análise de sua recente expansão (1995-2001). 279f. Tese (Doutorado em Sociologia) - Universidade de Brasília, 2003.

R. V. O uso de legenda oculta (closedcaptions) e a tradução de filmes: uma atividade prática, dinâmica e criativa. Dissertação (Mestrado em Lingüística Aplicada) - Departamento de Línguas Estrangeiras e Tradução, Brasília: Universidade de Brasília, 2005.

SPANOS, G.; SMITH, J. J. Closed caption television for adult LEP literacy learners [on line], 2003.2 Disponível em: <www.wricfacility.net/ericdigests/ed321623.html.> Acesso em: 14 ago. 2012.

SOARES, M. S. A. et al. A educação superior no Brasil. Disponível em $<$ http://unesdoc.unesco.org/images/0013/001393/139317por.pdf>. Acessoem: 12 nov. 2012

STORY, M. F. Principles of universal design. In: PREISER, W. F. E.; OSTROFF, E. (ed). Universal Design Handbook. New York, 2008.

STREINER, D.I.; NORMAN, G.R.Health measurement scales. A practicalguide to their development and use. Oxford: Oxford University Press, 1995.

TAKAHASHI, T. Sociedade da informação no Brasil: livro verde. Brasília: Ministério da Ciência e Tecnologia, 2000. 
TEDESCO, Juan Carlos (Org.). Educação e novas tecnologias: esperança ou incerteza? São Paulo/Buenos Aires/Brasília: Cortez/Instituto Internacional de Planeamiento de laEducación/Unesco, 2004.

O novo pacto educativo. São Paulo/Buenos Aires/Brasília: Cortez/Instituto Internacional de Planeamiento de laEducación/Unesco, 1995.

THOMPSON, S. J.; JOHNSTONE, C. J.; THURLOW, M. L. Universal design applied to large scale assessments (Synthesis Report 44). Minneapolis: University of Minnesota, National Center on Educational Outcomes, 2002.

TIDD, Joe; BESSANT, John; PAVITT, Keith. Gestão da inovação. 3. ed. São Paulo: Bookman, 2008.

TINDALL-FORD, S.; CHANDLER, P.; SWELLER, J. When two sensory modes arebetter than one. Journalof Experimental Psychology, 3(4), 257-287, 1997.

UDL - CENTER. Homepage. Disponível em: <http://www.udlcenter.org/>. Acesso em: 12 jun. 2011.

UNESCO. Declaração de Salamanca e linha de ação sobre necessidades educativas especiais. Brasília: CORDE, 1994.

Declaração Mundial sobre Educação Superior no Século XXI: visão e ação. Paris: Conferência Mundial sobre Ensino Superior (1998). Disponível em:

<http://www.interlegis.gov.br/processo_legislativo/copy_of_20020319150524/20 030620161930/20030623111830>. Acessoem: 1 ago. 2011.

VALLERAND, R. J. et al.On the assessment of intrinsic, extrinsic and amotivation in education: evidence on the concurrent and construct validity of the Academic Motivation Scale. Educational and Psychological Measurement 53, 160-172, 1993.

VALLERAND, R. J.The academic motivation scale: a measure of intrinsic, extrinsic, and amotivation in education. EducationalandPsychologicalMeasurement, n. 52, p. 1003-1017, 1992.

VELOSO, N. A. Administração em educação. Rio de Janeiro: Livros Técnicos, 1999.

VERAS FILHO, S. O uso didático da legenda intralingual no desenvolvimento da habilidade de leitura compreensão. UniversidadeEstadual do Ceará, 2007. 
VERDIN, F.B. R.; VICARI, R. M. Projeto de um agente fuzzy para inferir a autoeficácia do aluno no contexto de sistemastutores inteligentes. LeeeLatinAmericaTransactions, vol. 4, n. 6, dec. 2006.

VERNON, M. D.Motivação humana. Petrópolis: Vozes, 1973.

VINCE, R. A.(Ed.). Multimedia systems \& applications(p. 79-99). SanDiego: Academic Press, s/d.

VYGOTSKY, L. S. Pensamento e linguagem. São Paulo: Martins Fontes, 1987.

A formação social da mente. São Paulo: Martins Fontes, 1991.

WAKEFIELD, M. A. Design Universal para a Aprendizagem Diretrizes versão 2.0. Disponível em: <http://pepsic.bvsalud.org/scielo. php?pid=S180856872006000200006\&script=sci_arttext>. Acesso em: 17 jul. 2011.

WC3. O que é acessibilidade? In: Acessibilidade na Web: o caminho das pedras para construir sítios acessíveis. Disponível em: <http://www.w3c.br/palestras/2009/conip2009/slidy/template.html>. Acessoem: 17 jul. 2011.

WEINER, B.A. An attributional theory of achievement motivation and emotion. Psychological Review, n. 92 (4), p. 548- 573, 1985.

WENTZEL, K. R. Motivation and achievement in adolescence: A multiple goalsperspective. In: SCHUNK, D. H.; MEECE, J. L. (eds.). Student perceptions in the classroom (p. 287-306). New Jersey: Lawrence Erlbaum, 1992.

WENTZEL, K. R. What is it that I'm trying to achieve? Classroom goals from a contentperspective. ContemporaryEducationalPsychology, n. 25, p. 105$115,2000$.

WERNECK, Hamilton. Ninguém mais vai ser bonzinho, na sociedade inclusiva. Rio de janeiro: WVA, 1997.

WERNECK, Hamilton. Ousadia de pensar. 5. ed. Rio de Janeiro: DP\&A, 2000.

WILLIS, B. Distance education: strategies and tools. New Jersey: Education Technology Publicatons, 1994.

WOOD JR., Thomaz. Reformando o ensino e o aprendizado de gestão da produção e operações. In: SIMPOI 2000. São Paulo. Anais... São Paulo: EAG/FGV, 2000.

WOOLFOLK, H. A. College teaching and learning. In: KAZDIN, A. (ed.) Encyclopedia of psychology, v. 3, p. 179-181, 2000. 
YACHI, M. Online lecture viewer with automatic playback speed control based on learner's note taking. In: T. Amiele B. Wilson (Eds.). Proceedings of World Conference on Educational Multimedia, Hypermedia and Telecommunications, 2012.

YODER, J.A. et al.Dilemas do Ensino Superior na América Latina. Campinas: Papirus, 1994.

ZIMMERMAN, B. J. Self-efficacy: an essential motive to learn. Contemporary Educational Psychology, n. 25, p. 82-91, 2000.

ZIMMERMAN, B.J.; BANDURA, A.; MARTINEZ-PONS, M.Self-motivation for academic attainment: The role of self-efficacy beliefs and personal goal setting. American EducationalResearchJournal, 29, 663-676, 1992. 


\section{Anexos}

\section{Anexo I - Escala de Motivação Acadêmica (VALLERAND et. al., 1992; 1993)}

\section{Participante:}

Matrícula:

Usando a escala ${ }^{1}$ abaixo, indique - por favor - em que extensão cada um dos itens corresponde, atualmente. a uma das razốes porque você vem à Universidade.

$\begin{array}{cccccc}\begin{array}{c}\text { Nenhuma } \\ \text { correspondência }\end{array} & \begin{array}{c}\text { Pouca } \\ \text { correspondência }\end{array} & \begin{array}{c}\text { Moderada } \\ \text { correspondência }\end{array} & \begin{array}{c}\text { Muita } \\ \text { correspondência }\end{array} & \begin{array}{c}\text { Total } \\ \text { correspondência }\end{array} \\ 1 & 2 & 3 & 4 & 5 & 6\end{array}$

1. Porque preciso do diploma, ao menos, a fïn de conseguir uma ocupação bem remunerada. no futuro

2. Porque sinto satisfaçäo e prazer enquanto aprendo coisas novas

3. Porque acho que a formação universitária ajuda a me preparar melhor para a carreira que escolhi

4. Porque gosto muito de vir à universidade

5. Honestamente, nâo sei; acho que estou perdendo meu tempo na universidade

6. Pelo prazer que sinto quando supero a mim mesmo nos estudos

7. Para provar a mim mesmo que sou capaz de completar o curso

8. A fim de obter um emprego de prestígio, no futuro

9. Pelo prazer que sinto quando descubro coisas novas que nunca tinha visto ou conhecido antes 1234567

10. Porque o curso me capacitará, no final, a entrar no mereado de trabalho de uma área que eu gosto

11. Porque, para mim, a universidade é um prazer

12. Já tive boas razōes para isso; agora, entretanto, eu me pergunto se devo continuar

13. Pelo prazer que sinto quando supero a mim mesmo em alguma de minhas realizaçōes pessoais 1234567

14. Por causa do fato que me sinto importante quando sou bem sucedido na universidade

15. Porque quero levar uma boa vida no futuro

16. Pelo prazer que tenho $\mathrm{em}$ ampliar meu conhecimento sobre assuntos que me atraem

17. Porque isso me ajudará a escolher melhor minha orientaçäo profissional

18. Pelo prazer que tenho quando me envolvo em debates com professores interessantes

19. Não atino (percebo) porque venho à universidade e, francamente, nảo me precupo com isso 1234567

20. Pela satisfação que sinto qua ndo estou no processo de realização de atividades acadêmicas difíceis

21. Para mostrar a mim mesmo que sou uma pessoa inteligente

22. A fim de ter uma boa remuneraçăo no futuro

23. Porque meus estudos permitem que continue a aprender sobre muitas coisas que me interessam

24. Porque eu creio que a formaçãouniversitária aumentará minha competência como profissional 1234567

25. Pela euforia que sinto quando leio sobre vários assuntos interessantes

1234567

26. Não sei; não entendo o que estou fazendo na universidade

27. Porque a universidade me permite sent ir uma satisfação pessoal na minha busca por excelêneia na formaçäo

28. Porque quero mostrar a mim mesmo que posso ter sucesso nos meus estudos

6Diante do exposto,assinalo com um traço na linha abaixo o grau de minha motivação global para prosseguir nos estudos de Medicinaº

Fonte: SOBRAL, Dejano T. Motivação do aprendiz de medicina: uso da escala de Motivação acadêmica. Psic.: Teor. e Pesq. Brasília, v. 19, n. 1, Apr. 2003. 


\section{Anexo II - itens da Escala de Autoeficácia Acadêmica Percebida (DE SÁ, 2002)}

\begin{tabular}{|c|c|}
\hline Item 1 & Assimilar nowos conteúdos. \\
\hline Item 2 & Pedir a professor explic afföes complementares para compre ender o que acabou de ser explic ado. \\
\hline Item 3 & Frutegar as tarefas solicitadas nos pramos estipulados pelos professores. \\
\hline Item 4 & Expor os conteúdos lecionados em prowa escrita. \\
\hline Item 5 & Fmitir sua opinắ sobre un tema em discussão diarte dos seus colegas de tumma. \\
\hline Item 6 & $\begin{array}{l}\text { Argumentar com un colega de grupo que o traballio precisa ser mellior ado porque não está a } \\
\text { contento. }\end{array}$ \\
\hline Item 7 & Solicitar a professor a revisão de uma prova por discordar da nota que the foi atribuida. \\
\hline Item 8 & Defender un ponto de vista que difere da opinuáo da maioria dos seus colegas de tomma. \\
\hline Item 9 & Sugerir so professor que modifique sua fomma de arraliş ão. \\
\hline Item 10 & Expor os conteúdos lecionados em prova oral. \\
\hline Item 11 & Explicar a importância de suas posifõos acadêmicas para seus colegas de estudo. \\
\hline Item 12 & $\begin{array}{l}\text { Aprender somente prestando atery ão as anlas, utilizarido-se do estudo fora da escola apenas } \\
\text { como revisăo. }\end{array}$ \\
\hline Item 13 & Integrar novas informações is já existentes. \\
\hline Item 14 & hrutar-se a un gropo nowo para re alizar una tarefa com notas individusis. \\
\hline Item 15 & Fager associações pertinentes entre os conteúdos de disciplinas afins. \\
\hline Item 16 & Representar un gryo de estudo em un congresso. \\
\hline Item 17 & 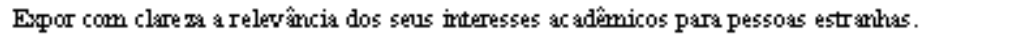 \\
\hline Item 18 & Adequar suas necessidades pessoais is exizâncias demandad as pelo estudo. \\
\hline Item 19 & Antecipar as questôes de una verific af ão oral ou escrita a partir dos conteúdos ensinados. \\
\hline Item 20 & $\begin{array}{l}\text { Comprir com o calendário de tarefas ac adêmic as pres erwando o rendimento em todas as } \\
\text { disciplinas arsadas. }\end{array}$ \\
\hline
\end{tabular}

Fonte: DE SÁ, A. P. Propriedades psicométricas de uma escala de auto-eficácia acadêmica e suas relações com desempenho estudantil e interação social. Rev. bras.ter. cogn.Rio de Janeiro, v. 2, n. 2, dez. 2006. 